SANDIA REPORT

SAND95-1675 - UC-814

Unlimited Release

Printed November 1995
Fit D

MAR 041990

\section{OSTI}

Yucca Mountain Site Characterization Project

\title{
Evaluation of Geotechnical Monitoring Data From the ESF North Ramp Starter Tunnel April 1994 to June 1995
}

YMP Performance Assessment, Applications Department 6313

YMP Las Vegas Operations, Department 6314

Agapito Associates, Inc.

\section{Prepared by}

Sandia National Laboratories

Albuquerque, New Mexico 87185 and Livermore, California 94550

for the United States Department of Energy

under Contract DE-AC04-94AL85000

Approved for public release; distribution is unlimited. 
"Prepared by Yucca Mountain Site Characterization Project (YMSCP) participants as part of the Civilian Radioactive Waste Management Program (CRWM). The YMSCP is managed by the Yucca Mountain Project Office of the U.S. Department of Energy, DOE Field Office, Nevada (DOE/NV). YMSCP work is sponsored by the Office of Geologic Repositories (OGR) of the DOE Office of Civilian Radioactive Waste Management (OCRWM)."

Issued by Sandia National Laboratories, operated for the United States Department of Energy by Sandia Corporation.

NOTICE: This report was prepared as an account of work sponsored by an agency of the United States Government. Neither the United States Government nor any agency thereof, nor any of their employees, nor any of their contractors, subcontractors, or their employees, makes any warranty, express or implied, or assumes any legal liability or responsibility for the accuracy, completeness, or usefulness of any information, apparatus, product, or process disclosed, or represents that its use would not infringe privately owned rights. Reference herein to any specific commercial product, process, or service by trade name, trademark, manufacturer, or otherwise, does not necessarily constitute or imply its endorsement, recommendation, or favoring by the United States Government, any agency thereof or any of their contractors or subcontractors. The views and opinions expressed herein do not necessarily state or reffect those of the United States Government, any agency thereof or any of their contractors.

Printed in the United States of America. This report has been reproduced directly from the best available copy.

Available to DOE and DOE contractors from

Office of Scientific and Technical Information

PO Box 62

Oak Ridge, TN 37831

Prices available from (615) 576-8401, FTS 626-8401

Available to the public from

National Technical Information Service

US Department of Commerce

5285 Port Royal Rd

Springfield, VA 22161

NTIS price codes

Printed copy: A08

Microfiche copy: A01 
SAND95-1675

Distribution Category

Unlimited Release

UC-814

Printed November 1995

\title{
EVALUATION OF GEOTECHNICAL MONITORING DATA FROM THE ESF NORTH RAMP STARTER TUNNEL APRIL 1994 TO JUNE 1995
}

\author{
YMP Performance Assessment \\ Applications Department 6313 \\ Sandia National Laboratories \\ Albuquerque, NM 87185 \\ YMP Las Vegas Operations \\ Department 6314 \\ Sandia National Laboratories \\ Las Vegas, NV 89109 \\ Agapito Associates, Inc. \\ Las Vegas, NV 89102
}

\begin{abstract}
Geotechnical monitoring data were developed during excavation of the North Ramp Starter Tunnel (NRST) and Alcove No. 1 to provide the basis for design verification. The NRST was constructed to launch the 7.6-m diameter tunnel boring machine being used to construct the Exploratory Studies Facility main access tunnels, the North Ramp, Main Drift, and South Ramp. Alcove No. 1 was excavated off the NRST to provide access for site characterization testing.

Rock mass quality data and blasting seismic data were collected during construction. Monitoring instrumentation consisted of rockbolt load cells, convergence points, and multi-point extensometers. Instrumentation stations were developed after the installation of final ground support. Rockbolt load and rock deformation data were used to assess stability of the excavation. Convergence data and rockbolt load were used to evaluate the ground support performance. Rock mass quality assessments were used to compare installed ground support to empirical ground support designs.
\end{abstract}

\section{MASTER}

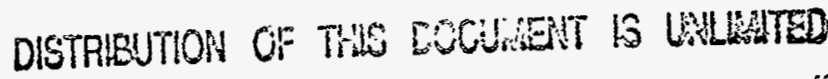


Rev 1

\section{CONTENTS}

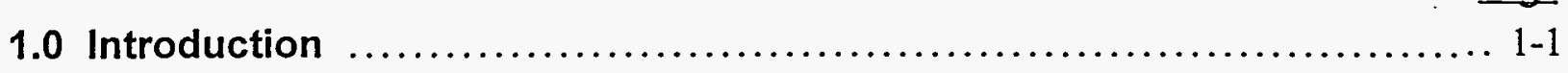

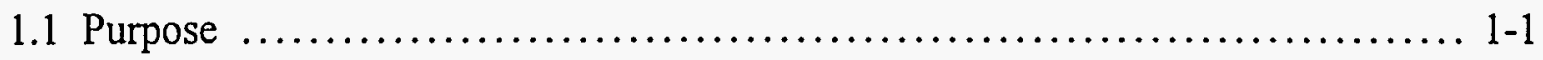

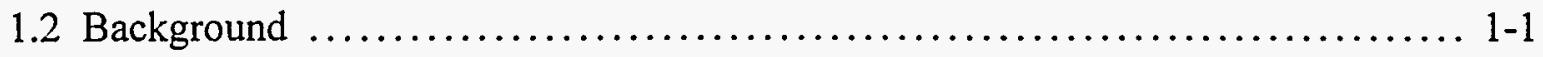

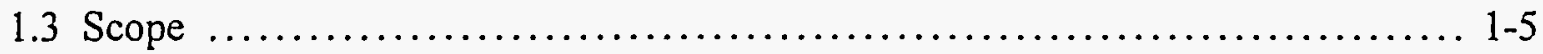

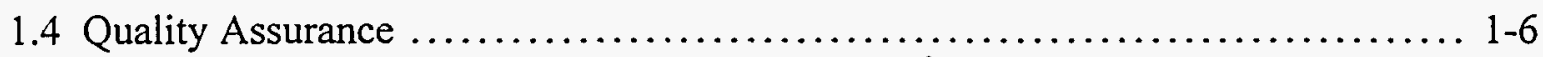

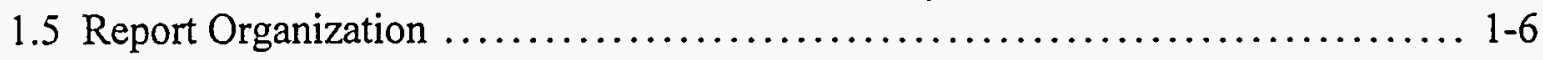

2.0 NRST Layout and Configuration of Monitoring Instrumentation ......... 2-1

2.1 Introduction $\ldots \ldots \ldots \ldots \ldots \ldots \ldots \ldots \ldots \ldots \ldots \ldots \ldots \ldots \ldots \ldots \ldots \ldots \ldots \ldots \ldots \ldots \ldots \ldots \ldots \ldots, 1$

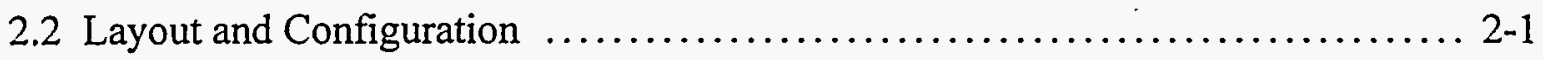

2.2.1 Box Cut $\ldots \ldots \ldots \ldots \ldots \ldots \ldots \ldots \ldots \ldots \ldots \ldots \ldots \ldots \ldots \ldots \ldots \ldots \ldots \ldots \ldots \ldots \ldots \ldots \ldots \ldots \ldots \ldots \ldots \ldots, 1$

2.2 .2 Tunnel $\ldots \ldots \ldots \ldots \ldots \ldots \ldots \ldots \ldots \ldots \ldots \ldots \ldots \ldots \ldots \ldots \ldots \ldots \ldots \ldots \ldots \ldots \ldots \ldots \ldots \ldots \ldots, 2-3$

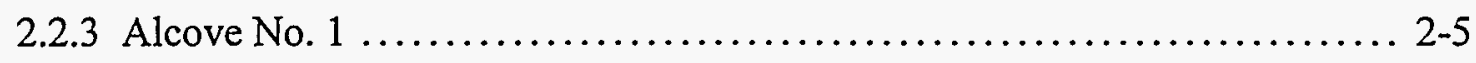

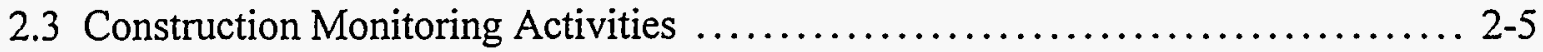

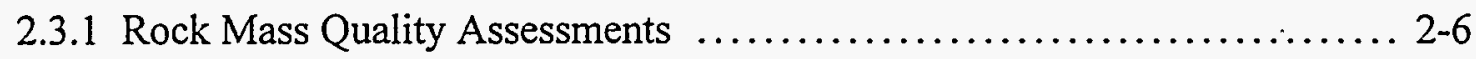

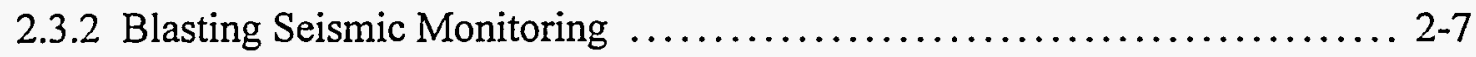

2.3.3 Ground Support Monitoring ................................... 2-13

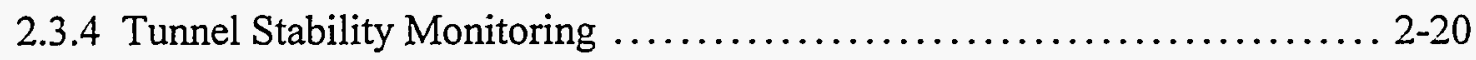

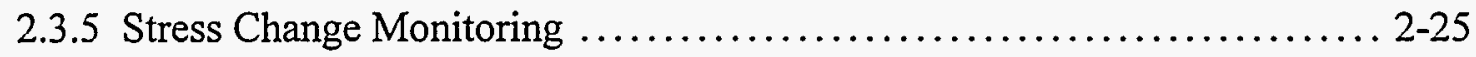

2.4 Data Acquisition and Analysis ..................................... 2-28

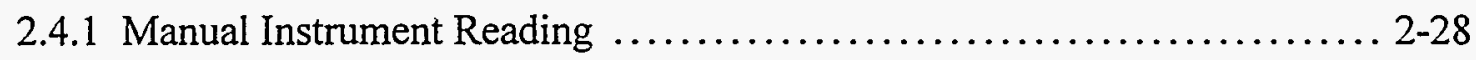

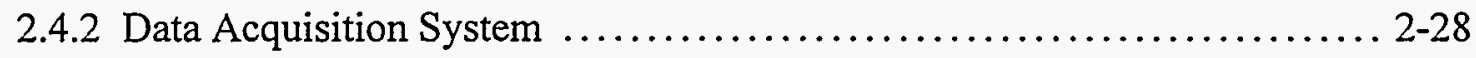

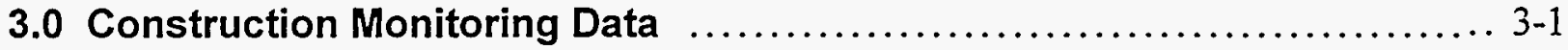

3.1 Introduction $\ldots \ldots \ldots \ldots \ldots \ldots \ldots \ldots \ldots \ldots \ldots \ldots \ldots \ldots \ldots \ldots \ldots \ldots \ldots \ldots \ldots \ldots \ldots \ldots \ldots \ldots \ldots, 1$

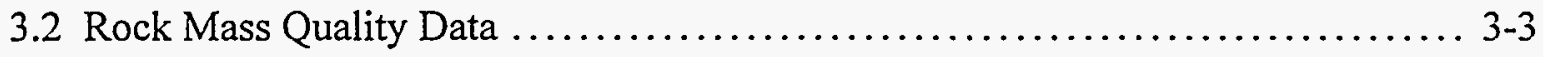

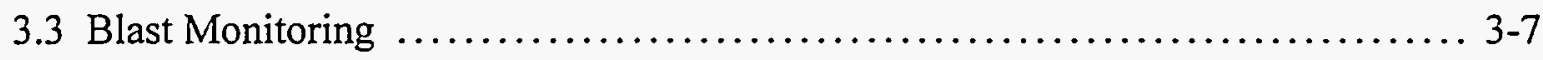

3.3.1 Scaled Distance Results for NRST Top Heading Blasting ............. 3-9

3.3.2 Alcove No. 1 Near-Field Blast Monitoring . ..................... 3-13

3.3.3 Evaluation of Blast Damage by Borehole Video Logs ................ 3-17

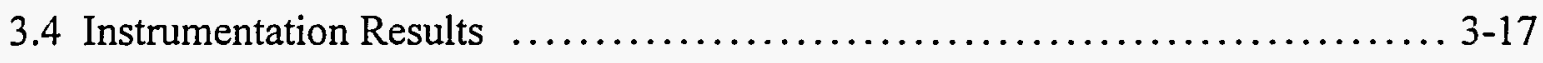

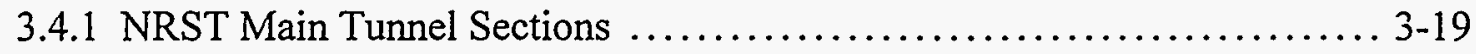

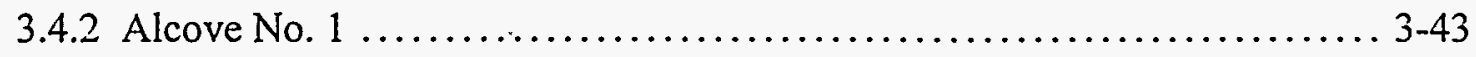

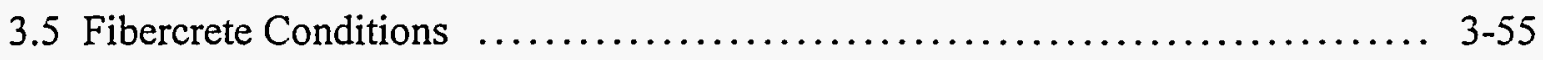

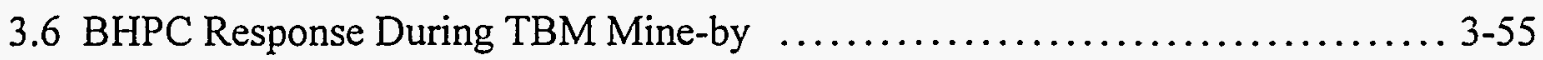

4.0 North Ramp Starter Tunnel-Design/Performance Verification .......... 4-1

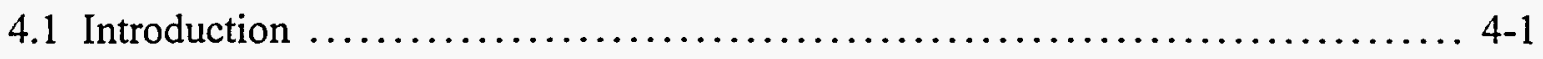

4.2 Monitoring Mining Methods-Blast Monitoring $\ldots \ldots \ldots \ldots \ldots \ldots \ldots \ldots \ldots, 4-2$ 
Page

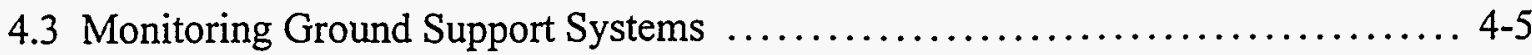

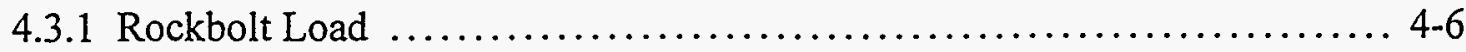

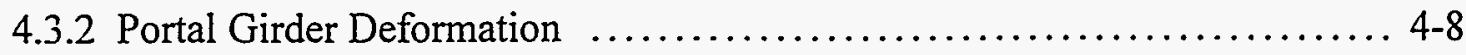

4.3.3 Visual Mapping of Fibercrete Cracking ......................... 4-10

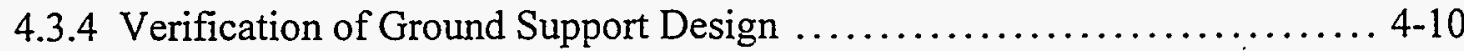

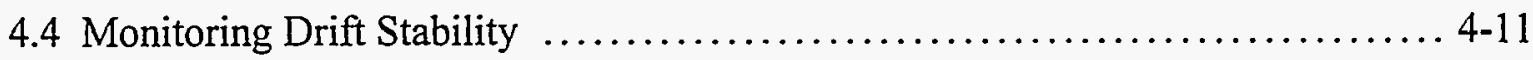

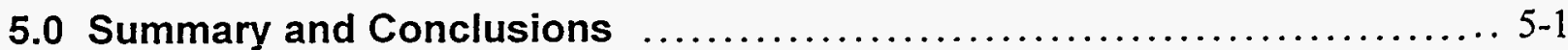

6.0 References $\ldots \ldots \ldots \ldots \ldots \ldots \ldots \ldots \ldots \ldots \ldots \ldots \ldots \ldots \ldots \ldots \ldots \ldots \ldots \ldots \ldots \ldots \ldots \ldots \ldots \ldots, 1$

APPENDIX A-Traceability of NRST Data

APPENDIX B-NRST Plan Map with Instrument Locations

APPENDIX C - NRST Instrument Stations and Data Acquisition System

APPENDIX D-U.S. Bureau of Reclamation Full Periphery Map/Starter Tunnel

DTN: GS940208314224.002

APPENDIX E-NRST Top Heading and Alcove No. 1 Blast Monitoring Data

APPENDIX F-Empirical Ground Support Design Category

APPENDIX G-North Ramp Starter Tunnel Fibercrete Crack Mapping

\section{Figures}

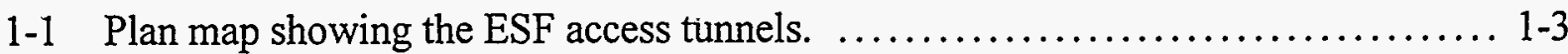

1-2 Cross section through Exile Hill showing the North Ramp Starter Tunnel. ........ 1-4

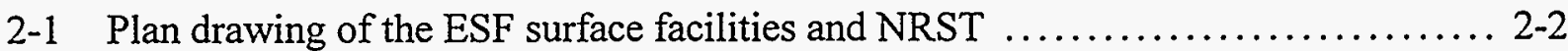

2-2 Cross section of starter tunnel illustrating top headings and bench configuration $\ldots \ldots \ldots \ldots \ldots \ldots \ldots \ldots \ldots \ldots \ldots \ldots \ldots \ldots \ldots \ldots \ldots \ldots \ldots \ldots \ldots \ldots \ldots \ldots, 4$

2-3 Example of Everlert II blasting seismic records. . . . . . . . . . . . . . . . .

2-4 Locations of blasting seismographs for NRST blast monitoring. ............. 2-11

2-5 Layout of near-field blast monitoring instrument and damage inspection holes.... 2-12

2-6 Plan drawing of NRST portal area showing location of lattice girders with

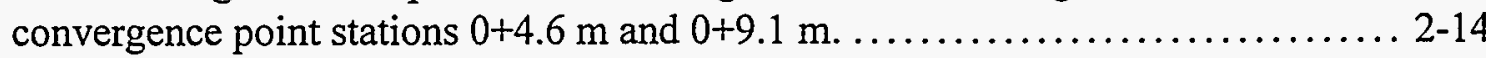

2-7 Generalized cross section of NRST convergence points installed on lattice girders, looking northwest. ...................................... 2-15

2-8 Schematic of rockbolt pattern on the portal face, showing the locations of the RBLCs looking northwest. ..................................... 2-18

2-9 General cross section of the NRST showing pattern of grouted rockbolts installed for final support. ........................................ 2-19

2-10 General convergence pin layout for the Main Tunnel and Alcove No. 1........ 2-21

2-11 Cross sections of the NRST Main Tunnel and Alcove No. 1 showing typical configurations of the extensometers. 
Rev 1

2-12 Schematic showing configuration of the TBM launch chamber in the NRST and location of the borehole pressure cells. $2-26$

3-1 Schedule of activities in NRST construction monitoring program............. 3-2

3-2 Variation of $Q_{\min }$ and $Q_{\max }$ with NRST station for the Main Tunnel-Top

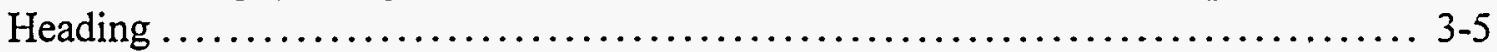

3-3 Variation of $Q_{\min }$ and $Q_{\max }$ with NRST station for the Main Tunnel bench ......... 3-6

3-4 Frequency of occurrence of parameters used to determine $Q_{m i n}$ and $Q_{m a x}$-all data. ....................................................... 3-8

3-5 PPV versus SD (distance normalized to charge weight to the $1 / 2$ power)....... 3-11

3-6 PPV versus SD (distance normalized to charge weight to the $1 / 3$ power)........ 3-12

3-7 PPV versus SD for the square root of charge weight-Top Heading and Alcove No. 1 blast data. ......................................... 3-15

3-8 PPV versus SD for the cube root of charge weight-Top Heading and Alcove No. 1 blast data. ................................................... 3-16

3-9 PPV at 0.91 and $2.4 \mathrm{~m}$ compared to range projected to cause damage by Holmberg and Persson (1979) ..................................... 3-18

3-10 Rockbolt load versus time-station $0+00 \mathrm{~m}$, portal face. ................. 3-20

3-11 Convergences versus time for lattice girder No. 4 at NRST station $0+4.6 \mathrm{~m} . \quad \ldots \ldots$ 3-22

3-12 Convergence versus time for lattice girder No. 7 at NRST station $0+9.1 \mathrm{~m} . \quad \ldots \ldots .3-23$

3-13 Convergence versus time-NRST station $0+10.7 \mathrm{~m} \ldots \ldots \ldots \ldots \ldots \ldots \ldots \ldots \ldots \ldots \ldots \ldots .24$

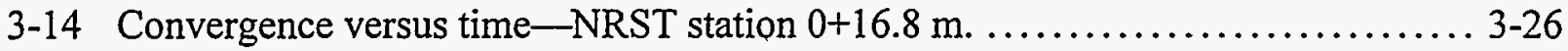

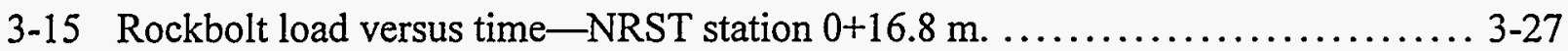

3-16 Convergence versus time--NRST station $0+27.4 \mathrm{~m} \ldots \ldots \ldots \ldots \ldots \ldots \ldots \ldots \ldots \ldots \ldots \ldots \ldots .28$

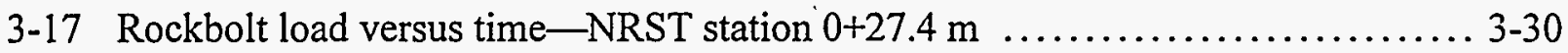

3-18 Convergence versus time-NRST station $0+33.5 \mathrm{~m} \ldots \ldots \ldots \ldots \ldots \ldots \ldots \ldots \ldots \ldots \ldots . .31$

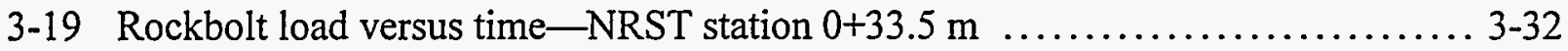

3-20 Convergence versus time-NRST station $0+42.7 \mathrm{~m} . \ldots \ldots \ldots \ldots \ldots \ldots \ldots \ldots \ldots \ldots \ldots \ldots .34$

3-21 Vertical MPBX displacement versus time-NRST station 0+42.7 m. .......... 3-35

3-22 Vertical MPBX displacement rates versus time-NRST station 0+42.7 m. ...... 3-36

3-23 Rockbolt load versus time-NRST station $0+42.7 \mathrm{~m} . \ldots \ldots \ldots \ldots \ldots \ldots \ldots \ldots \ldots \ldots \ldots .37$

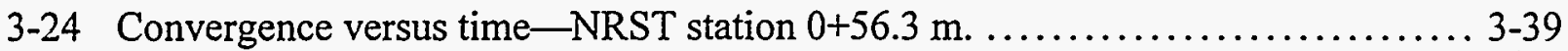

3-25 Vertical MPBX displacement versus time-NRST station $0+56.3 \mathrm{~m} . \ldots \ldots \ldots \ldots .3-40$

3-26 Vertical MPBX displacement rates versus time-NRST station 0+56.3 m. ...... 3-41

3-27 Horizontal MPBX displacement versus time-NRST station 0+56.3 m. ........ 3-42

3-28 Horizontal MPBX displacement rates versus time-NRST station $0+56.3 \mathrm{~m}$. . ... 3-44

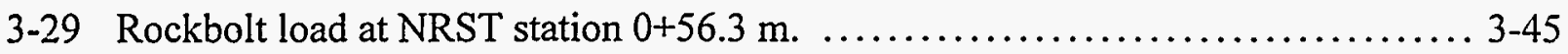

3-30 Convergence versus time-Alcove No. 1 station $0+4.6 \mathrm{~m} . \ldots \ldots \ldots \ldots \ldots \ldots \ldots \ldots \ldots \ldots .46$

3-31 Convergence versus time-Alcove No. 1 station $0+11.3 \mathrm{~m} . \ldots \ldots \ldots \ldots \ldots \ldots \ldots \ldots \ldots .47$

3-32 Convergence versus time-Alcove No. 1 station $0+17.7 \mathrm{~m} . \ldots \ldots \ldots \ldots \ldots \ldots . . . \ldots .48$ 
3-33 Convergence versus time-Alcove No. 1 station 0+24.4 m.

3-34 Vertical MPBX displacement versus time-Alcove No. 1 stations $0+11.3$ and $0+24.4 \mathrm{~m}$.

3-35 Vertical MPBX displacement rate versus time-Alcove No. 1 stations $0+11.3$

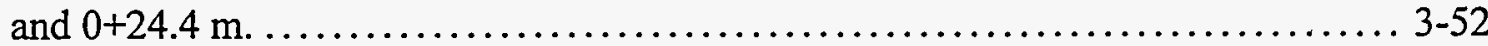

3-36 Rockbolt load versus time-Alcove No. 1 station $0+4.6 \mathrm{~m} . \ldots \ldots \ldots \ldots \ldots \ldots \ldots .3-53$

3-37 Rockbolt load versus time-Alcove No. 1 stations $0+11.5,0+14.0,0+17.7$,

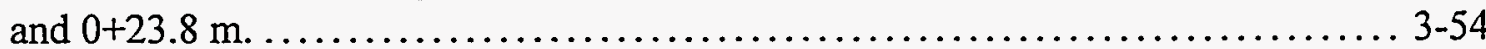

3-38 Pressure history for BHPC Nos. 1 and 2 for the TBM mine-by period .......... 3-57

3-39 BHPC response to the TBM gripper pad loads-horizontal direction ............ 3-59

3-40 BHPC response to the TBM gripper pad loads-vertical direction ............. 3-60

3-41 Structural geology of the North Ramp in the vicinity of the BHPCs .......... . 3-62

4-1 Comparison of bolt load history to bolt yield strength for different stations in the NRST. .................................................. 4-7

4-2 Comparison of bolt load history for IRBs in Alcove No. 1 ................ 4-9

4-3 Comparison of NRST closure rates to stability criteria. ................... 4-14

\section{Tables}

1-1 In Situ Design Verification Study Plan Experiments Objectives and Activities ..... 1-6

1-2 Specific Investigations Conducted in the North Ramp Starter Tunnel ............ 1-7

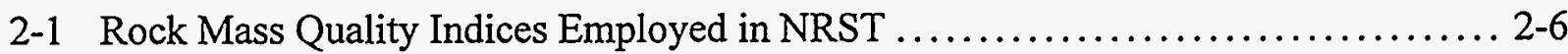

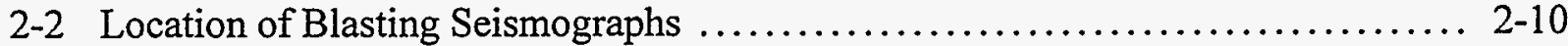

2-3 Location and Type of Instrumented Rockbolts ......................... 2-17

2-4 Location, Orientation, and Anchor Depths of NRST Extensometers ............ 2-23

2-5 Configuration of Individual BHPCs in Each Hole ....................... 2-27

3-1 Range of Rock Mass Quality for the NRST ........................... 3-4

3-2 Length-Weighted Log Mean Values of $Q_{\min }$ and $Q_{\max }-$ NRST Main Tunnel ........ 3-6

3-3 Comparison of Curve Fits of PPV versus SD using Equations 3-2 and 3-3 ....... 3-10

3-4 Combined Near-Field/Far-Field Curve Fit . .......................... 3-14

3-5 Schedule of TBM Advance Between 0+60.2 and 0+74.4 m ................ 3-58

4-1 Stability Performance Measures and Goals for Repository Drifts ............... 4-3

4-2 Comparison of Empirical Ground Support versus Installed Ground Support ...... 4-12 
Rev 1

\subsection{Introduction}

\subsection{Purpose}

This report presents the results of instrumentation measurements and observations made during construction of the North Ramp Starter Tunnel (NRST) of the Exploratory Studies Facility (ESF). The information in this report was developed as part of the Design Verification Study, Section 8.3.1.15.1.8 of the Yucca Mountain Site Characterization Plan (DOE 1988). The ESF is being constructed by the U.S. Department of Energy (DOE) to evaluate the feasibility of locating a potential high-level nuclear waste repository on lands within and adjacent to the Nevada Test Site (NTS), Nye County, Nevada. The Design Verification Studies are performed to collect information during construction of the ESF that will be useful for design and construction of the potential repository. Four experiments make up the Design Verification Study: Evaluation of Mining Methods, Monitoring Drift Stability, Monitoring of Ground Support Systems, and The Air Quality and Ventilation Experiment. This report describes Sandia National Laboratories' (SNL) efforts in the first three of these experiments in the NRST.

\subsection{Background}

The NRST was constructed to launch the 7.6-m tunnel boring machine (TBM) being utilized to excavate the North Ramp of the ESF. The North Ramp is one of two inclined tunnels currently planned to provide access to the potential repository horizon. The North Ramp will be excavated ${ }^{1} 2,804 \mathrm{~m}(9,200 \mathrm{ft})$ to the potential repository horizon. Beyond this point, the

'ESF Layout Calculation, BABEAD000-01717-0200-00003, Revision 2. 
Rev 1

Topopah Spring Level (TSL) Main Drift will be excavated 3,131 m (10,273 ft) across the proposed repository block by the TBM. The South Ramp will then be excavated 1,921 m $(6,302 \mathrm{ft})$ to connect to the surface. Figure 1-1 shows a map of the locations of the planned ESF access tunnels, and the location of the North Portal.

The NRST was excavated by drill-and-blast techniques in the east face of Exile Hill, a horst-like structure between the Midway Valley and Bow Ridge Faults, in Miocene volcanic tuff rocks of the Paintbrush Group, Tiva Canyon Member, upper lithophysal zone. A geologic cross section through Exile Hill showing the location of the NRST is presented in Figure 1-2.

The NRST excavation consisted of three parts:

- a box cut to form safety benches and to allow safe construction of the tunnel brow,

- a finished size of approximately $10-\mathrm{m}(32.8-\mathrm{ft})$ high by $10-\mathrm{m}$ (32.8-ft) wide tunnel with arched roof excavated to $0+60.2 \mathrm{~m}$, and

- an alcove (No. 1) driven at an angle of $82^{\circ}$ to the tunnel to provide access for testing/ characterization.

All parts of the NRST were excavated in generally poor rock mass conditions that resulted from the presence of cavernous lithophysae, minor fault and shear structures, vertical jointing, and weathering effects due to surface proximity. The construction took place in unsaturated, highly fractured rocks and no water flow of construction significance was encountered.

Ground support requirements were relatively heavy due to the poor rock quality. Temporary ground support was provided by split set rockbolts and wire mesh. The permanent support in the tunnel brow consisted of steel lattice girders embedded in fibercrete. Beyond the brow area, final support consisted of $3-\mathrm{m}, 4.9-\mathrm{m}$ and $7.3-\mathrm{m}$ (10-ft, 16-ft and 24-ft) long, fully grouted, untensioned rockbolts with a nominal $15.2 \mathrm{~cm}(6 \mathrm{in})$ of fibercrete. 


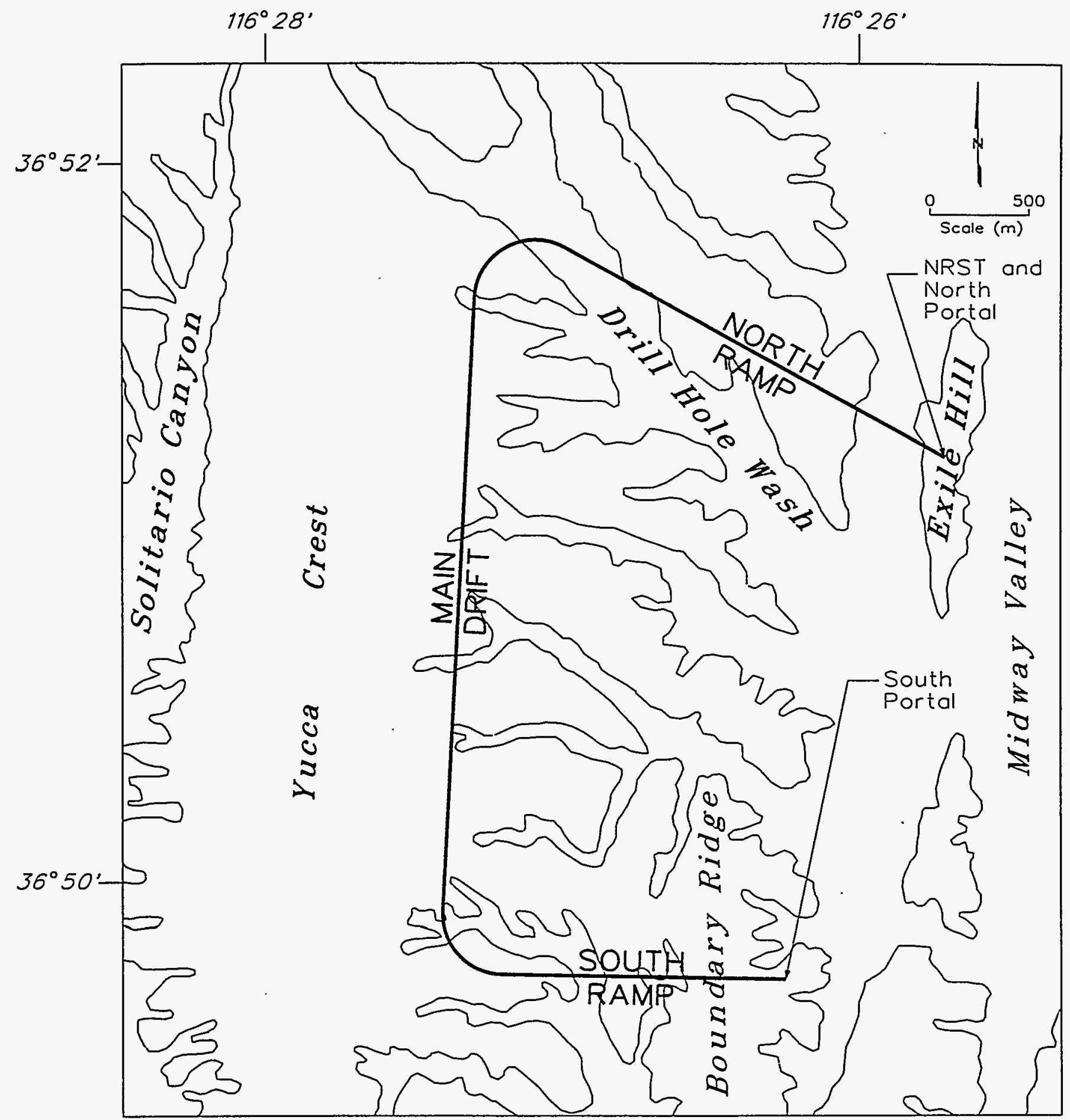

Figure 1-1. Plan map showing the ESF access tunnels. 


\section{Rev 1}

CROSS SECTION CONSTRUCTED

ALONG RAMP ALIGNMENT - AZIMUTH $299^{\circ}$

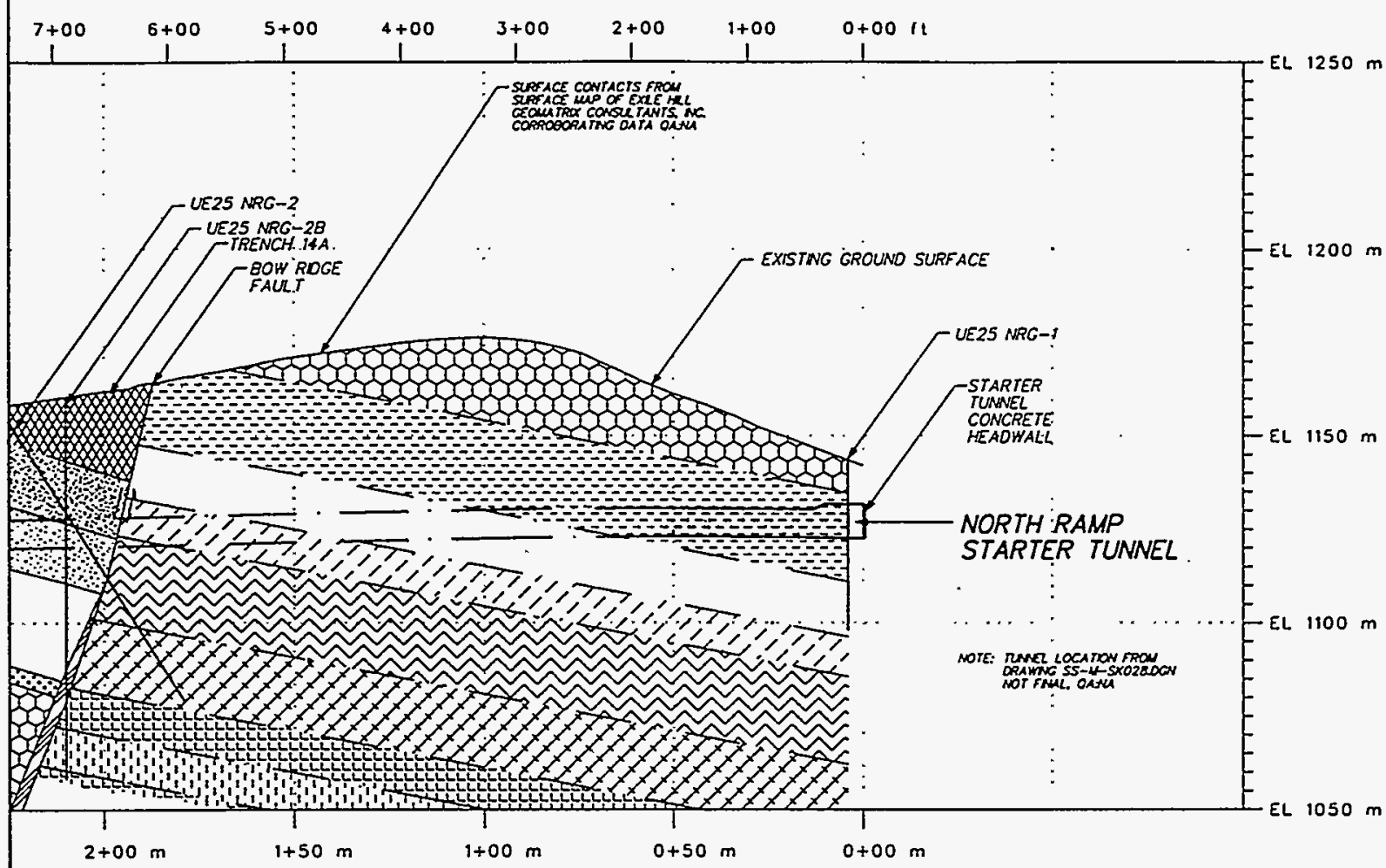

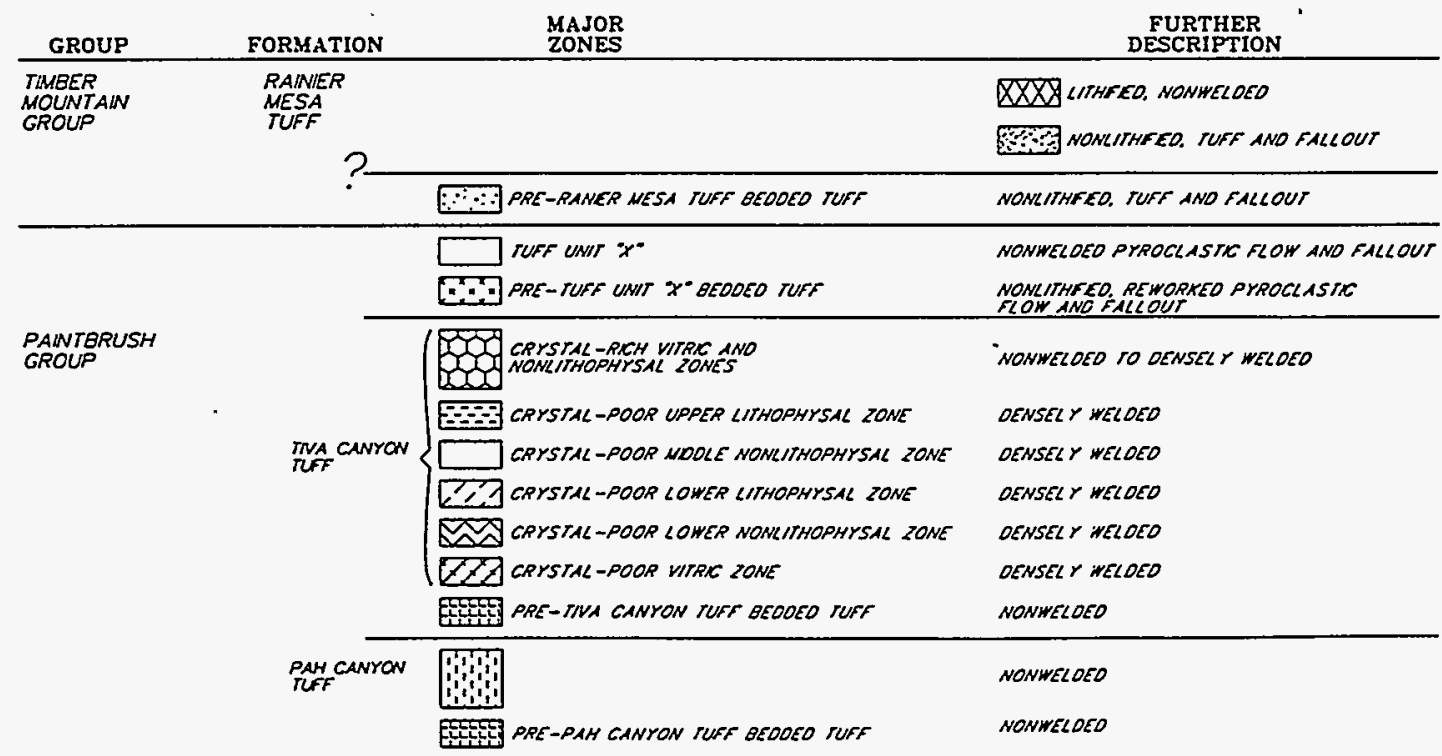

Figure 1-2. Cross section through Exile Hill showing the North Ramp Starter Tunnel. 


\subsection{Scope}

This report presents the results of design verification (DV) studies conducted during construction of the NRST between North Ramp stations $0+00$ and $0+60 \mathrm{~m}$. Data were collected in three of the four design verification experiments:

- evaluation of mining methods,

- evaluation of ground support systems, and

- monitoring drift stability.

The overall objectives of these design verification experiments are to monitor and observe the long-term behavior of openings in the range of rock conditions to be encountered in the potential repository host rock, to observe and evaluate the construction of the ESF with respect to implications for repository construction and performance, and to collect information for design of the ventilation systems in the repository underground facility. The ventilation studies were not implemented in the NRST monitoring.

Table 1-1 lists more specific objectives and activities within each of the design verification experiments implemented in the NRST. In Table 1-2, the study activities are correlated with specific investigations that were performed in the NRST and the specific data to be collected.

Two activities, blast seismic monitoring and rock quality evaluation, were conducted in parallel with the excavation process. These data were developed for the upper heading and bench excavations in the tunnel and for the alcove. All other investigations were conducted as the final support was installed, hence, the influence of the excavation process on rock movement was not monitored. 


\section{Table 1-1. In Situ Design Verification Study Plan Experiments (8.3.1.15.1.8) Objectives and Activities}

\begin{tabular}{|c|c|c|c|}
\hline $\begin{array}{c}\text { SCP } \\
\text { Activity No. }\end{array}$ & $\begin{array}{l}\text { Study Plan } \\
\text { Experiment }\end{array}$ & Objectives & Activities \\
\hline$\overline{8.3 .1 .15 .1 .8 .1}$ & $\begin{array}{l}\text { Evaluation of } \\
\text { mining methods }\end{array}$ & $\begin{array}{l}\text { Record methods and equipment used, } \\
\text { describe resulting excavations in terms of } \\
\text { conformance to specifications and extent } \\
\text { of observable excavation effects, correlate } \\
\text { with rock mass quality } Q \text { and RMR. }\end{array}$ & $\begin{array}{l}\text { - Rock mass quality evaluation } \\
\text { - Monitoring blast vibrations } \\
\text { - Evaluate as-built mapping data } \\
\text { - Collect construction records on } \\
\text { blasting rounds }\end{array}$ \\
\hline 8.3 .1 .15 .1 .8 .2 & $\begin{array}{l}\text { Evaluation of } \\
\text { ground support } \\
\text { system }\end{array}$ & $\begin{array}{l}\text { Record installed ground support, correlate } \\
\text { with rock mass quality, measure } \\
\text { load-deformation response of some } \\
\text { ground support components, monitor in } \\
\text { situ loads on some supports, evaluate } \\
\text { performance in terms of deformations and } \\
\text { usability of excavations. }\end{array}$ & $\begin{array}{l}\text { - Collect ground support records } \\
\text { - Monitor rockbolt loads } \\
\text { - Monitor lattice girder convergence } \\
\text { - Observe shotcrete cracks }\end{array}$ \\
\hline 8.3 .1 .15 .1 .8 .4 & $\begin{array}{l}\text { Monitor drift } \\
\text { stability }\end{array}$ & $\begin{array}{l}\text { Measure cross-drift convergence } \\
\text { throughout the ESF and at several } \\
\text { intersections, monitor rock movement } \\
\text { with borehole extensometers, record rock } \\
\text { falls and required maintenance. }\end{array}$ & $\begin{array}{l}\text { - Measure cross-drift convergence } \\
\text { - Measure intersection convergence } \\
\text { - Monitor rock displacements } \\
\text { - Observe rock falls }\end{array}$ \\
\hline
\end{tabular}

\subsection{Quality Assurance}

Information and data presented in this report were developed and documented under a fully qualified Quality Assurance (QA) program. The information was documented in scientific notebooks in accordance with SNL's Quality Assurance Implementing Procedure (QAIP) 20-2. Traceability of the information and data is outlined in Appendix A.

\subsection{Report Organization}

This report is organized into six sections and appendices. Following this introduction, Section 2.0 describes the NRST construction, the layout, and location of the construction monitoring instruments and the specific activities. Section 3.0 presents summaries of the 
Rev 1

\section{Table 1-2. Specific Investigations Conducted in the North Ramp Starter Tunnel}

\begin{tabular}{ccc}
$\begin{array}{c}\text { Study Plan } \\
\text { Experiment }\end{array}$ & $\begin{array}{c}\text { Study Plan } \\
\text { Activity }\end{array}$ & $\begin{array}{c}\text { Specific } \\
\text { Investigation }\end{array}$ \\
\hline
\end{tabular}

Evaluate mining Rock mass quality Scanline mapping methods

Blast monitoring Far-field

Near-field

Evaluate as-built mapping data

Obtain USBR detailed mapping data

Evaluate ground Collect ground support systems support records
Collect construction records

Obtain constructor records on - Provide data to correlate with blast blasting Obtain constructor records on support design, installation

Correlate support with rock - Verify adequacy of design approach mass quality

Monitor ground support

Install rockbolt load cells - Verify performance of rockbolts Install lattice girder convergence pins

- Verify lattice girder performance and loading

- Verify fibercrete performance

Inspect fibercrete cracking

\begin{tabular}{llll}
\hline $\begin{array}{l}\text { Monitor drift } \\
\text { stability }\end{array}$ & $\begin{array}{l}\text { Cross drift } \\
\text { convergence } \\
\text { Intersection } \\
\text { convergence }\end{array}$ & $\begin{array}{l}\text { Install convergence pins } \\
\text { Install convergence pins and } \\
\text { extensometers at tunnel/ } \\
\text { alcove intersection }\end{array}$ & $\cdot$ - Veasure drift closure to verify stability \\
& Rock displacements & $\begin{array}{l}\text { Install multi-point } \\
\text { extensometers }\end{array}$ & •Verify rock mass stability \\
\hline \hline
\end{tabular}

construction monitoring data, with the resulting assessments of design/performance verification discussed in Section 4.0. Summary and conclusions are presented in Section 5.0. References are presented in Section 6.0 .

Appendices present some specific data from this work and other information that support the results. 


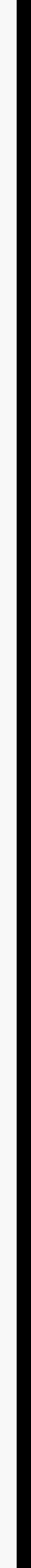


Rev 1

\subsection{NRST Layout and Configuration of Monitoring Instrumentation}

\subsection{Introduction}

This section of the report describes the construction of the NRST and the associated monitoring and site characterization activities. Excavation of the NRST included three separate elements: the box cut, the starter tunnel, and Alcove No. 1. Monitoring of the construction consisted of geotechnical observations of the exposed rock conditions, measurements of blasting seismic response, and installation of long-term monitoring instruments in the rock mass and on selected ground support components. Detailed structural mapping of the NRST was performed by the U.S. Bureau of Reclamation ${ }^{1}$ (USBR) in an associated investigation.

\subsection{Layout and Configuration}

Construction of the NRST consisted of the three elements of box cut, tunnel, and Alcove No. 1. A plan map showing the layout and configuration of the NRST with respect to the surface topography and surface facilities is presented in Figure 2-1.

\subsubsection{Box Cut}

The box cut was excavated to remove loose unstable material to allow development of the NRST portal. The tuff rocks of the Tiva Canyon upper lithophysal zone were excavated by mechanical ripping to form a portal face $21.3 \mathrm{~m}$ (70 ft) high by $41.1 \mathrm{~m}$ (135 ft) wide. The north

\footnotetext{
${ }^{1}$ Characterization of Structural Features in the Site Area, Study Plan 8.3.1.4.2.2.
} 


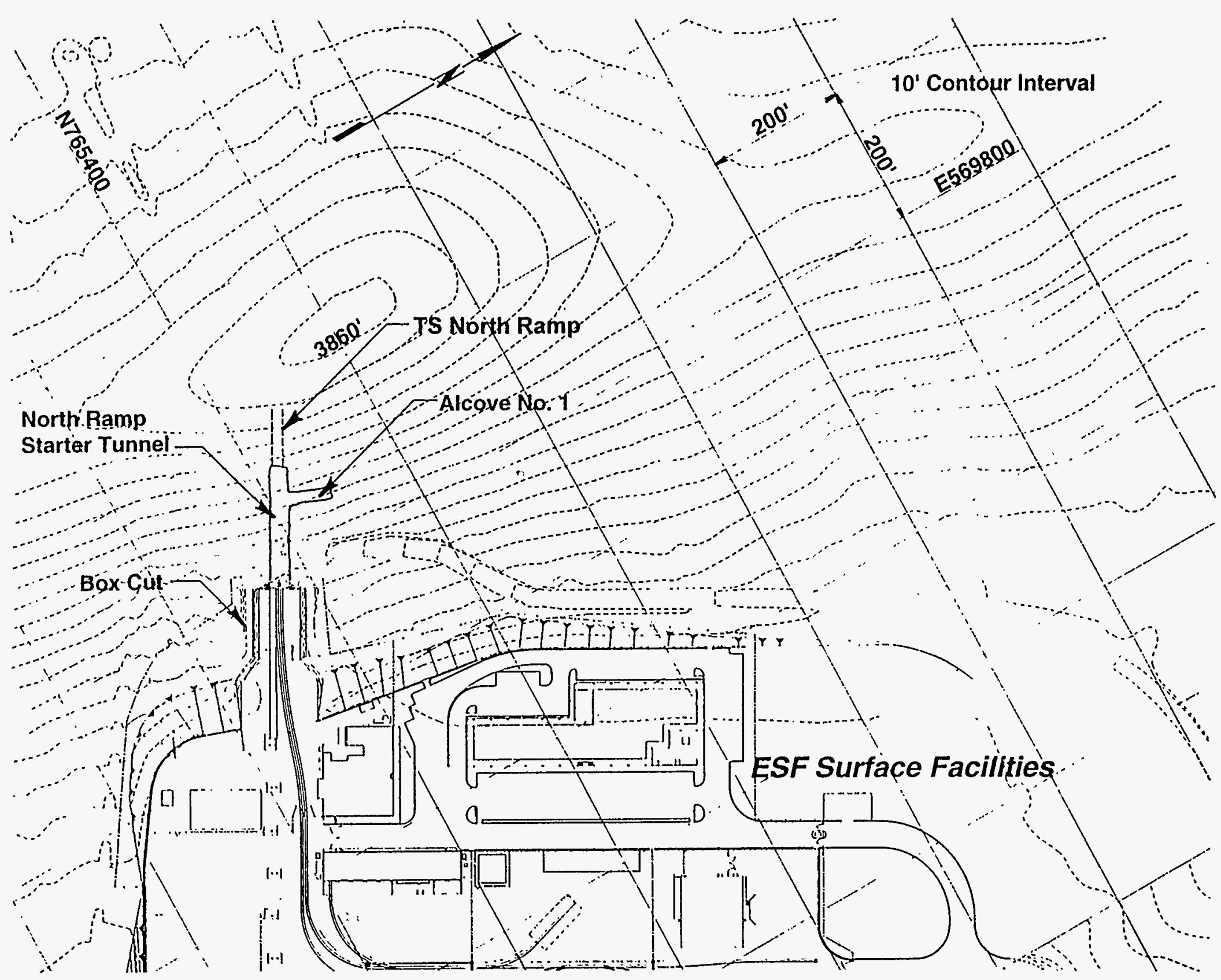

Figure 2-1. Plan drawing of the ESF surface facilities and NRST. 
Rev 1

and south walls were sloped by the formation of two benches and covered by 9-gage chain-link mesh secured by split set rockbolts. The portal face was later bolted using $6.1-\mathrm{m}(20-\mathrm{ft})$ long hollow rebar rockbolts which were grouted in place with cementitious grout The portal face was then fibercreted with a minimum thickness of $10.2 \mathrm{~cm}$ (4 in) which covered all mesh and bolts.

\subsubsection{Tunnel}

The tunnel was excavated nominally $9.8 \mathrm{~m}(32.3 \mathrm{ft})$ high by $9.9 \mathrm{~m}(32.5 \mathrm{ft})$ wide in an arched shape as shown in Figure 2-2. It was constructed in two passes consisting of a top heading and bench. Excavation was by conventional mining using drill-and-blast techniques. Loose rock was scaled and temporary rock support consisting of split set rockbolts with 100-mm by $100-\mathrm{mm}$ (4-in by 4 -in) welded wire mesh was installed after each blast round. Final support of fully grouted bolts and fibercrete was installed incrementally after completion of each phase of the excavation.

2.2.2.1 Top Heading. The top heading was accessed from an earth ramp built within the box cut. Figure 2-2 presents a cross section illustrating the nominal tunnel dimensions and shape. The top heading was excavated in two passes, a pilot drive followed by slashing of the north and south ribs. The nominal height was $5.2 \mathrm{~m}(17 \mathrm{ft})$ with a $9.9-\mathrm{m}(32.5-\mathrm{ft})$ width. The earth ramp was then removed from the box cut to allow access to the bench.

2.2.2.2 Bench. The bench was excavated by full-face horizontal drilling and blasting. The center bench cut was excavated one round ahead of the north and south cuts; however, after the initial rounds, the slashes were completed and subsequently all three cuts were blasted at the same time. Initial ground support consisting of split sets and welded wire mesh were installed in the ribs. 
SAND95-1675

Rev 1

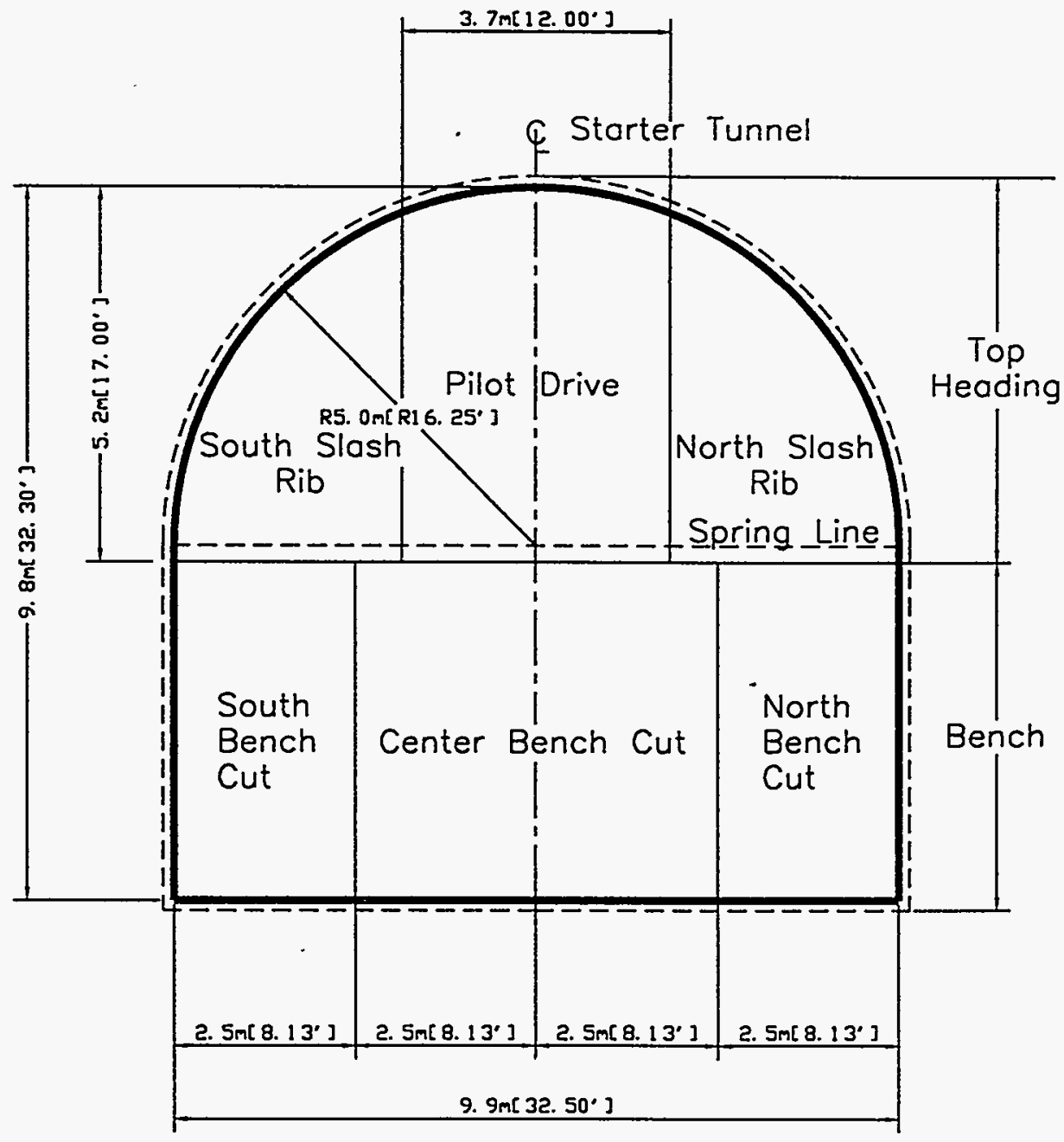

Figure 2-2. Cross section of starter tunnel illustrating top headings and bench configuration (from ESF Package 1A, YMP-025-1-MING-MG135, Rev 3). 
2.2.2.3 Ground Support. The final ground support system was installed following removal of the bench to full length of the NRST. This support consisted of untensioned grouted rockbolts between $3 \mathrm{~m}(10 \mathrm{ft})$ and $7.3 \mathrm{~m}(24 \mathrm{ft})$ long on $1.2 \mathrm{~m} \mathrm{(4ft)} \mathrm{centers,} 152-\mathrm{mm}$ by $152-\mathrm{mm}$ (6-in by 6-in) welded wire mesh, and a nominal thickness of $15.2 \mathrm{~cm}$ ( 6 in) of fibercrete. Steel lattice girders were installed near the portal and were completely embedded in fibercrete. Some additional fully grouted bolts were also installed through the fibercrete.

\subsubsection{Alcove No. 1}

Alcove No. 1 was excavated in the direction $\mathrm{N} 21^{\circ} \mathrm{E}$ at station $0+42.7 \mathrm{~m}(1+40 \mathrm{ft})$ as shown in plan view in Figure 2-1. The alcove had an arched cross section with nominal height of $5.2 \mathrm{~m}(17 \mathrm{ft})$ and a width of $5.8 \mathrm{~m}(19.0 \mathrm{ft})$ and was $22.9 \mathrm{~m}(75 \mathrm{ft})$ long. The alcove was excavated by conventional drill and blast using full-face blast rounds.

\subsection{Construction Monitoring Activities}

Construction monitoring activities were conducted in two phases. In the first phase, rock mass quality data, blasting seismic data, and temporary convergence data were collected during construction activities. After completion of the tunnel and alcove, final instrumentation in the form of convergence points, rockbolt load cells, instrumented rockbolts, extensometers, and stress change gages were installed and connected into a central data logging system. This section of the report describes each of these activities and the specific instrumentation installed. 


\subsubsection{Rock Mass Quality Assessments}

Rock mass quality assessments were made incrementally during the excavation of the top heading, bench, and Alcove No. 1. The rock mass quality indices were developed using the $\mathrm{Q}$ (Barton et al. 1974) and the RMR (Bieniawski 1979) systems. Individual parameters were subjectively assessed based on descriptive tables published for each system, with the exception of RQD which was assessed using a correlation between fracture frequency and RQD reported by Hudson and Priest (1979). Calculations and parameters are described in Table 2-1.

\section{Table 2-1. Rock Mass Quality Indices Employed in NRST}

\begin{tabular}{rlrl} 
NGI $-\mathbf{Q}$ & \multicolumn{1}{c}{$\mathrm{RMR}$} \\
\hline $\mathrm{Q}=\frac{\mathrm{RQD}}{\mathrm{J}_{\mathrm{N}}} \cdot \frac{\mathrm{J}_{\mathrm{R}}}{\mathrm{J}_{\mathrm{A}}} \cdot \frac{\mathrm{J}_{\mathrm{W}}}{\mathrm{SRF}}$ & $\mathrm{RMR}$ & $=\mathrm{C}+\mathrm{I}_{\mathrm{RQD}}+\mathrm{JS}+\mathrm{JC}+\mathrm{JW}+\mathrm{AJ}$ \\
where & where & \\
$\mathrm{RQD}$ & $=100 \mathrm{e}^{-0.1 \lambda}+(0.1 \lambda+1.0)$ & $\mathrm{C}$ & $=$ rock strength rating \\
$\lambda$ & $=$ average fracture frequency $\left(\mathrm{m}^{-1}\right)$ & $\mathrm{I}_{\mathrm{RQD}}$ & $=\mathrm{RQD}$ rating \\
$\mathrm{J}_{\mathrm{N}}$ & $=$ joint set number & $\mathrm{JS}$ & $=$ joint spacing parameter \\
$\mathrm{J}_{\mathrm{R}}$ & $=$ joint roughness number & $\mathrm{JC}$ & $=$ joint characteristics parameter \\
$\mathrm{J}_{\mathrm{A}}$ & $=$ joint alteration number & $\mathrm{JW}$ & $=$ joint water parameter \\
$\mathrm{J}_{\mathrm{W}}$ & $=$ joint water reduction factor & $\mathrm{AJO}$ & $=$ joint orientation adjustment \\
$\mathrm{SRF}$ & $=$ stress reduction factor & & \\
\hline \hline
\end{tabular}

Data were developed for different increments of the tunnel length during excavation, depending upon access for description. The RQD estimate was generated for three lines: one horizontal on the wall, one vertical on the wall, and one horizontal across the tunnel or bench face. Fracture frequency was determined by counting fractures along the scanline, with sheared or rubblized zones accounted for by length-weighted averaging using $\mathrm{RQD}=0 \%$ for the 
rubblized zone. Lithophysal cavities were considered by counting them as one fracture if the diameter was less than approximately $76.2 \mathrm{~mm}$ ( 3 in) or as two fractures if the diameter was greater than approximately $76.2 \mathrm{~mm}(3 \mathrm{in}) . \mathrm{RQD}$ was averaged for the three lines, the average value used as the upper value of the range, and the minimum of the three lines was used as the low value of the range.

Visual observations of the characteristics of the rock were used to estimate the range of conditions existing in the interval being examined for each of the other parameters in Table 2-1. The upper and lower values were then used to estimate a range of $Q$ for each interval of the upper bench and both $Q$ and RMR for the lower bench and Alcove No. 1. The $Q$ system can be used to assess the ground support requirements by using design charts. Appendix F provides background on the design charts and ground support categories.

\subsubsection{Blasting Seismic Monitoring}

Blasting seismic monitoring was performed to measure peak particle velocity (PPV) in the far-field ( $>3 \mathrm{~m}, 10 \mathrm{ft}$ ) for the top heading, bench, and Alcove No. 1 blasting, and in the near-field ( $<3 \mathrm{~m}, 10 \mathrm{ft})$ for the initial Alcove No. 1 blasts in an attempt to correlate blast-induced damage with PPV. Each of these activities is discussed separately in the following sections.

2.3.2.1 Far-Field Monitoring. Far-field monitoring was conducted in two separate phases for each of the top heading and bench mining activities. The monitoring was performed using blasting seismograph equipment manufactured by Vibratech Engineers, Inc. of Pittsburgh, Pennsylvania. Two instrument types were utilized, an Everlert 6000 and Everlert II. These systems had similar configurations and specifications and were equipped with one three-axis 
Rev 1

geophone and one blast air-pressure monitor. Resolutions of the particle velocity were $0.099 \mathrm{~mm} / \mathrm{sec}(0.0039 \mathrm{in} / \mathrm{sec})$ for the Everlert 6000 and $0.1239 \mathrm{~mm} / \mathrm{sec}(0.00488 \mathrm{in} / \mathrm{sec})$ for the Everlert II over the frequency ranges of $2-200 \mathrm{~Hz}$ and $2-250 \mathrm{~Hz}$, respectively. Accuracy was specified as $\pm 3 \mathrm{Db}$ over the frequency range and the dynamic range of the instruments was $0-203.2 \mathrm{~mm} / \mathrm{sec}(0-8 \mathrm{in} / \mathrm{sec})$ and $0-254.0 \mathrm{~mm} / \mathrm{sec}(0-10 \mathrm{in} / \mathrm{sec})$, respectively.

Both instruments were event triggered and capable of storing multiple events. Records of individual events were printed intermittently and correlated with individual blasts by using constructor records. Figure 2-3 shows an example of an individual record from the Everlert II. Each record contains the PPV, peak frequency, peak vector sum, the wave form of each of the three transducers, and calibration checks for each transducer. Blast air pressures were not monitored.

The two blasting seismographs were placed at different distances from the face in protected locations. Geophones were coupled directly to rock surfaces by placing sand bags on top of the instrument cases. Five different geophone locations were used to monitor the top heading blasts, and an additional two locations were used for the bench blasts. The coordinates are listed in Table 2-2 and illustrated in Figure 2-4. Geophone stations 1 and 2 were utilized for the initial blasting to form the top heading. After the top heading had advanced several rounds, the blast monitors were moved to geophone stations 3 and 4 for the majority of the top heading blasts. Station 5 was only used for two rounds, and then the geophones were returned to station 3. The box cut ramp was then removed and stations 6 and 7 were established to monitor the bench blasts. 


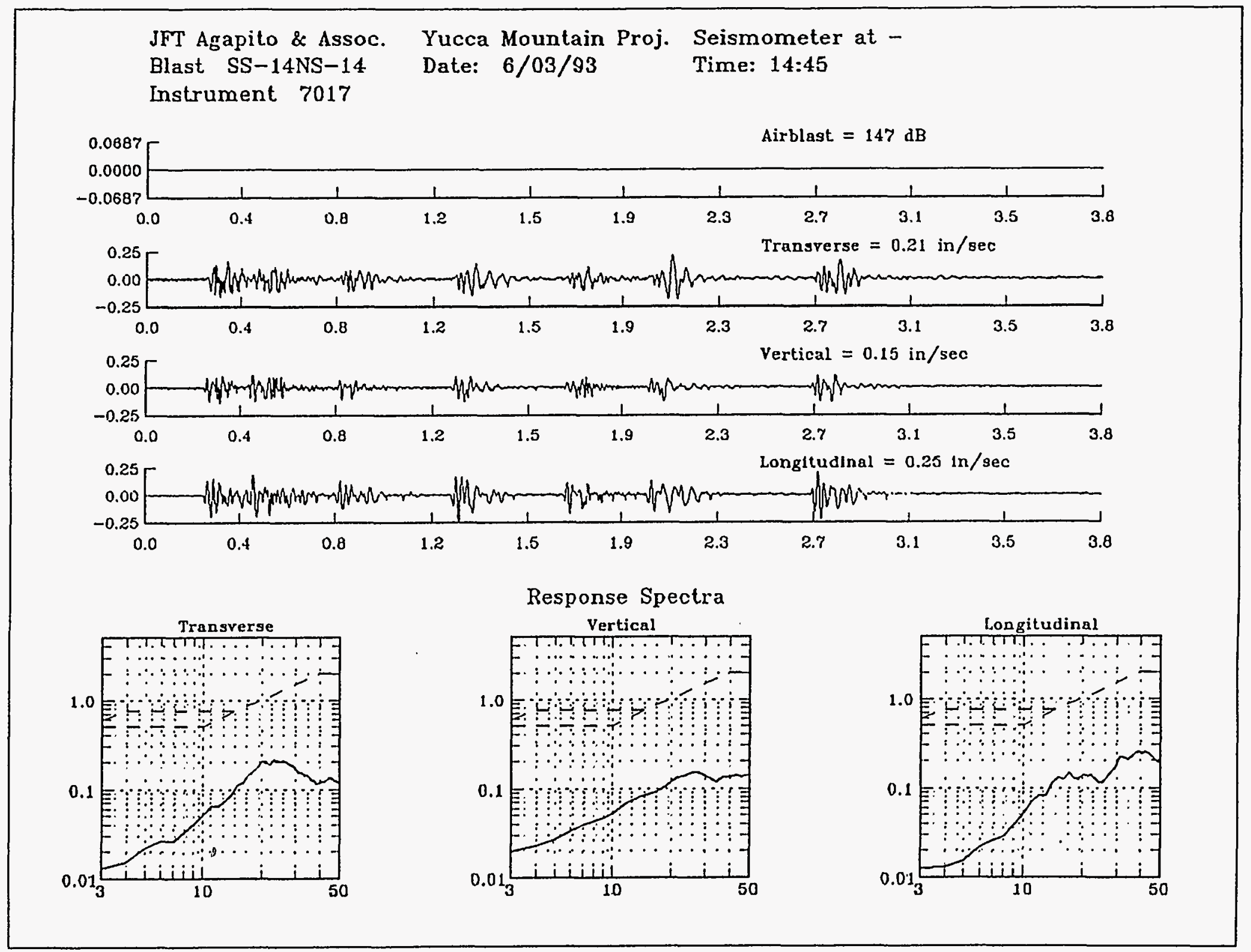

Figure 2-3. Example of Everlert II blasting seismic records. 


\begin{tabular}{|c|c|c|c|c|}
\hline \multirow{2}{*}{$\begin{array}{l}\text { Geophone } \\
\text { Station }\end{array}$} & \multicolumn{2}{|c|}{ North } & \multicolumn{2}{|c|}{ East } \\
\hline & (m) & (ft) & (m) & (ft) \\
\hline 1 & $233,267.9$ & $765,305.2$ & $173,740.7$ & $570,008.4$ \\
\hline 2 & $233,253.7$ & $765,258.6$ & $173,799.9$ & $570,202.9$ \\
\hline 3 & $233,283.5$ & $765,356.4$ & $173,703.4$ & $569,886.1$ \\
\hline 4 & $233,291.1$ & $765,381.3$ & $173,685.8$ & $569,828.5$ \\
\hline 5 & $233,286.6$ & $765,366.5$ & $173,678.6$ & $569,804.8$ \\
\hline $6^{*}$ & $233,290.3$ & $765,378.9$ & $173,686.0$ & $569,828.9$ \\
\hline $7^{*}$ & $233,291.6$ & $765,383.0$ & $173,675.0$ & $569,793.0$ \\
\hline
\end{tabular}

2.3.2.2 Near-Field Monitoring. Near-field blast monitoring was performed during excavation of Alcove No. 1 to measure PPV at small distances (1 and $2.4 \mathrm{~m}$ ) from the excavation perimeter and to attempt to observe blasting related damage in the wall of the alcove. Figure 2-5 illustrates the layout of the monitoring holes that were drilled from the NRST parallel to the axis of Alcove No. 1.

- Two holes each contained two geophones oriented to measure the compressional and vertical shear-wave vibrations. Vibration in the horizontal shear plane was not measured. The geophones, model GS-20DX-10Hz manufactured by OYO Geospace, were grouted $3 \mathrm{~m}$ deep in the monitoring holes located at $1 \mathrm{~m}$ and $2.4 \mathrm{~m}$ from the Alcove No. 1 perimeter at a height of $2.7 \mathrm{~m}$ above the floor. These geophones had a flat response over a frequency range of 15 to $<500 \mathrm{~Hz}$ and they were coupled to a Hewlett-Packard HP-54112D digital oscilloscope. Recording was done at a rate of 5000 samples per second for the duration of the blast, approximately 12 seconds. 


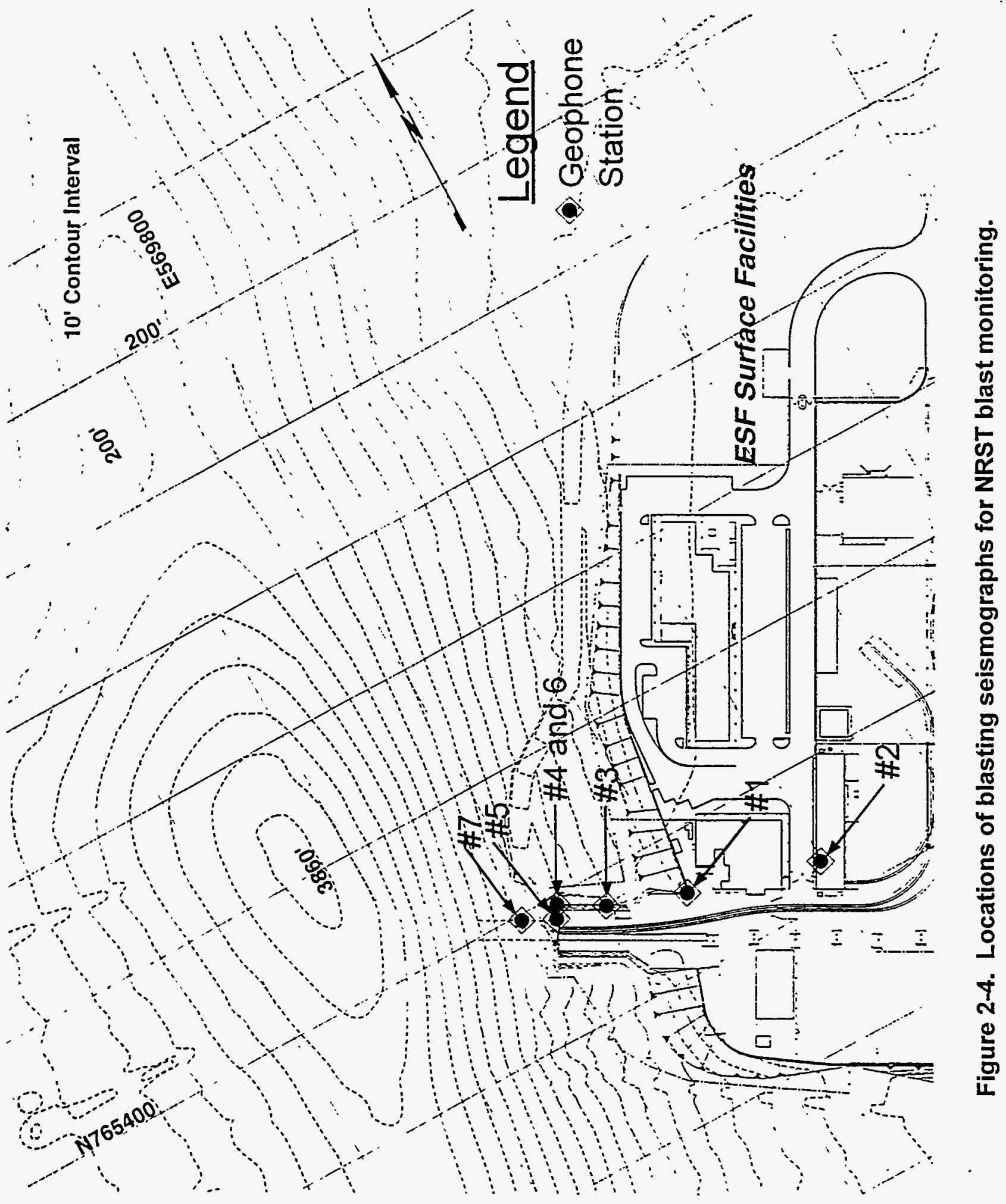


Rev 1

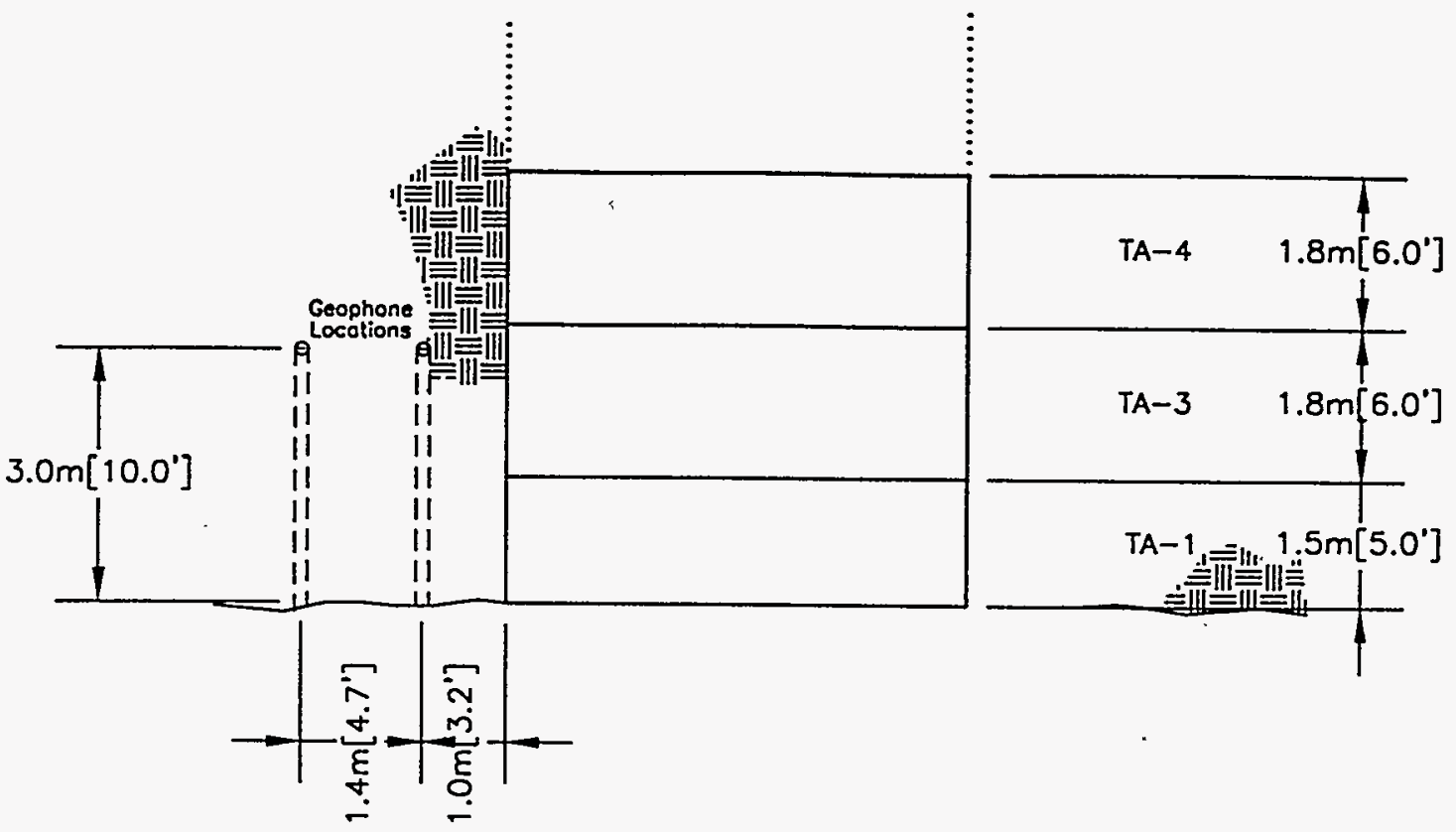

Plan View

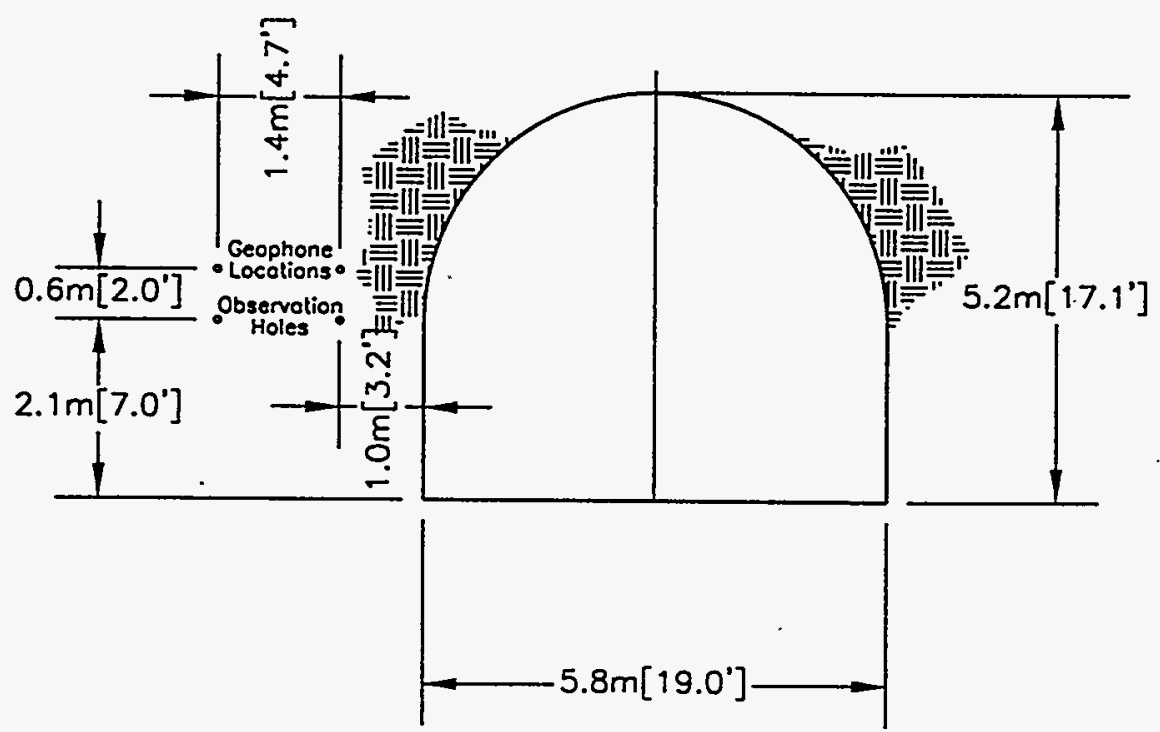

Cross Section

Figure 2-5. Layout of near-field blast monitoring instrument and damage inspection holes. 


\subsubsection{Ground Support Monitoring}

The performance of three types of ground support were monitored:

- lattice girders,

- rockbolts, and

- fibercrete.

The specific monitoring methods and instrumentation are described in the following subsections.

2.3.3.1 Lattice Girders. Steel lattice girders were installed in the first $10 \mathrm{~m}(32.8 \mathrm{ft})$ of the NRST and then embedded in fibercrete with a minimum cover of $38 \mathrm{~mm}\left(1 \frac{1}{2} \mathrm{in}\right)$. The lattice girders were 3-bar model CP70/6/10 manufactured by Commercial Pantex Sika, Inc. of Louisville, Kentucky. The seven lattice girders were installed in eight sections and secured to the rock by rockbolts. The lattice girders were set on wood blocking to provide a footing for the girders prior to their encapsulation in fibercrete.

Convergence point anchors were attached directly to girders No. 4 and No. 7 prior to application of the fibercrete. Figure 2-6 shows a plan drawing of the NRST portal with general locations of the lattice girder instrumentation. Girders No. 4 and No. 7 were located at ramp stations $0+4.6 \mathrm{~m}(0+15 \mathrm{ft})$ and $0+9.1 \mathrm{~m}(0+30 \mathrm{ft})$, respectively. Figure $2-7$ shows a generalized cross section of the opening, the location of convergence points, the chords measured, and the nomenclature used to identify the chords. Appendix B contains a D-size as-built plan drawing of the NRST and Alcove No. 1 with the location of each gage. Appendix C contains a D-size drawing that shows a schematic of the instrument stations in the NRST. 


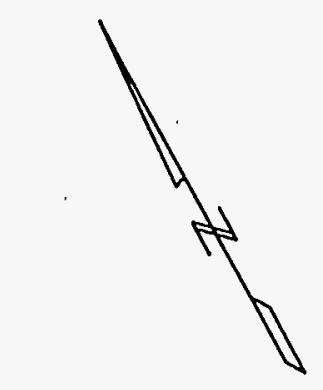

Convergence .Convergence

Points Points

NR Sto. $0+9.1 \mathrm{~m}$ NR Sto. $0+4.6 \mathrm{~m}$

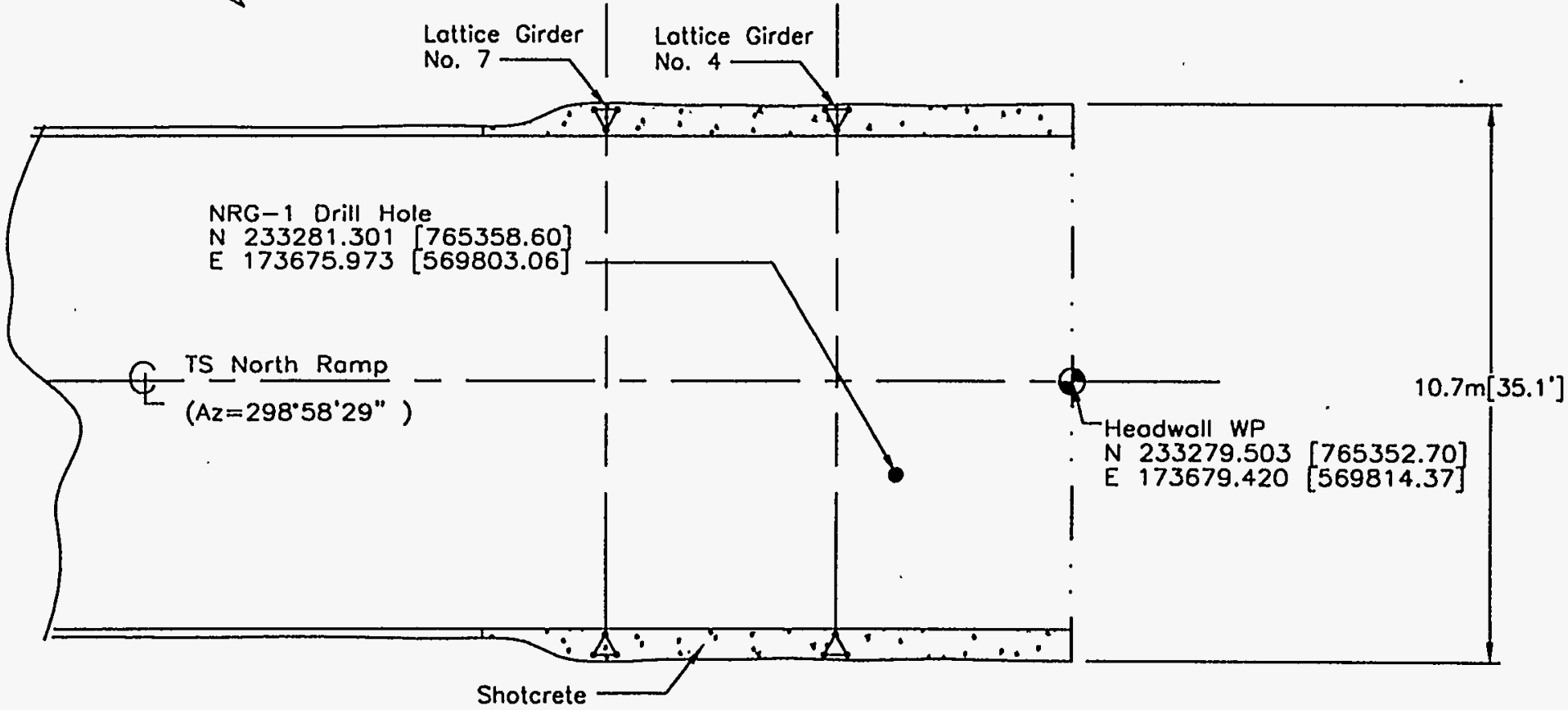

Figure 2-6. Plan drawing of NRST portal area showing location of lattice girders with convergence point stations 0+4.6 $\mathrm{m}$ and 0+9.1 $\mathrm{m}$ (from ESF Package 1A, YMP-025-1-MING-MG135, Rev 3). 
Rev 1
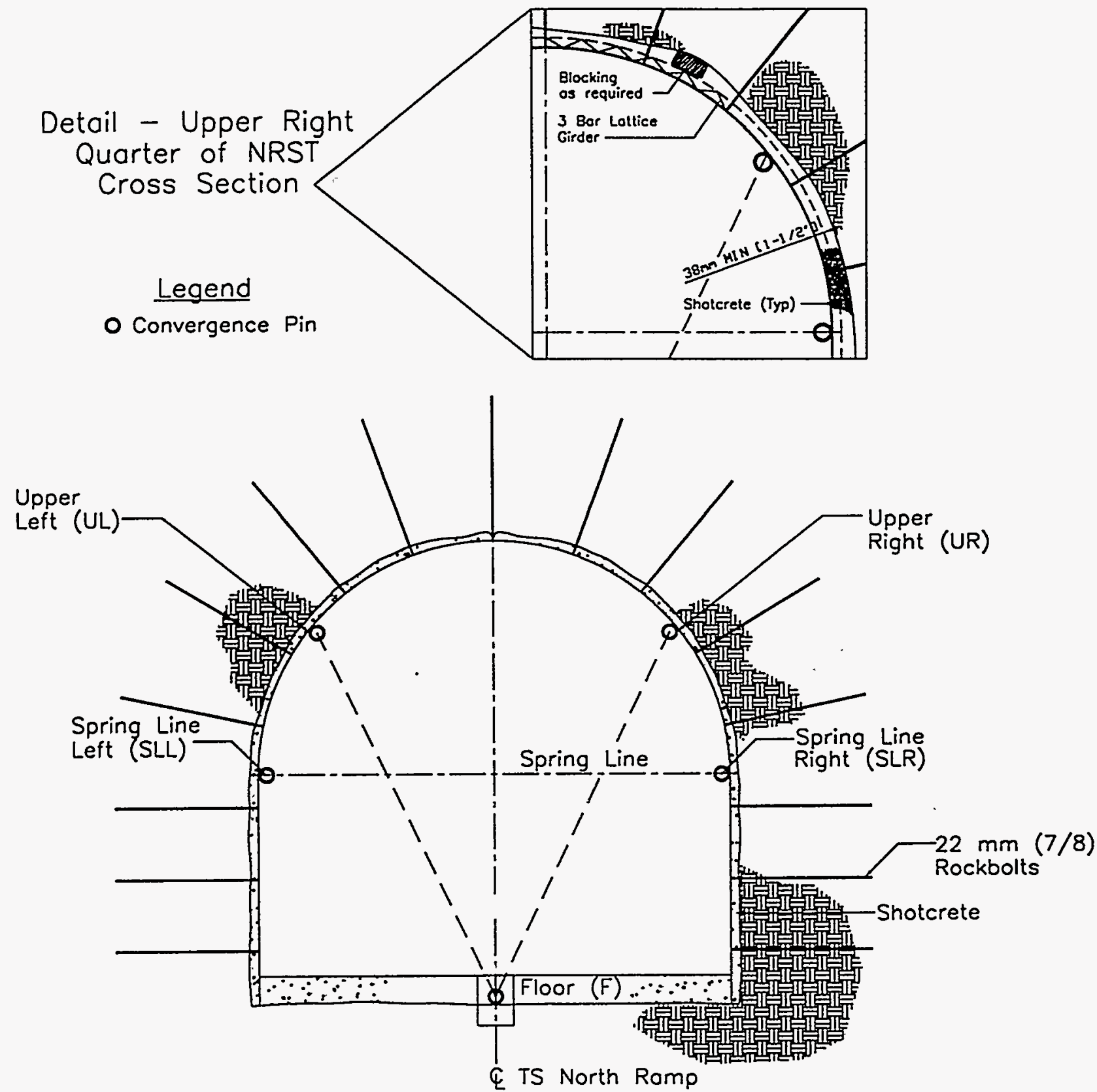

Figure 2-7. Generalized cross section of NRST convergence points installed on lattice girders, looking northwest (from ESF Package 1A, YMP-025-1-MING-MG152 Rev 1 and YMP-025-1-MING-MG153 Rev 1). 
2.3.3.2 Rockbolt Load. Two types of instrumentation were installed to monitor rockbolt load:

- rockbolt load cells (RBLCs) and

- instrumented rockbolts (IRBs).

Arrays of the RBLCs were installed at six stations in the NRST and the IRBs at five locations in Alcove No. 1. The locations, number, and types of instruments are listed in Table 2-3.

The face above the portal (highwall station $0+00 \mathrm{~m}$ ) was rock bolted using $6.1-\mathrm{m}(20-\mathrm{ft})$ long hollow $\# 9^{2}$ rebar bolts with couplings and $\# 7$ by $3 \mathrm{~m}$ (10-ft) bolts. The bolts were drilled in using sacrificial bits, then grouted in place using cementitious grout. The bolts were untensioned. The locations of the rockbolts and rockbolt load cells on the portal face (highwall) are shown in Figure 2-8.

Rockbolt pattern in the main tunnel of the NRST went through several modifications. The final configuration consisted of fifteen bolts: nine 3-7.3-m (10-24-ft) long bolts above the spring line and six 3-m (10-ft) long bolts in the ribs. All bolts were untensioned grouted, using cementitious grout. The bolts above spring line were \#9 $(28.6 \mathrm{~mm} ; 1.125 \mathrm{in})$ bolts and were pull tested to $249.1 \mathrm{kN}(56,000 \mathrm{lbs})$. The rib bolts were \#7 (22.2 mm; $8.75 \mathrm{in})$ diameter and were pull tested to $111.2 \mathrm{kN}(25,000 \mathrm{lbs})$. The typical bolt pattern is shown in Figure 2-9.

The main tunnel bolts and portal face were instrumented with Geokon Model Nos. 4900-45-2 and 4900-40-1.5 vibrating wire rock bolt load cells (RBLCs) with capacities of 200.2 and $177.9 \mathrm{kN}(45,000$ and $40,000 \mathrm{lbs})$, respectively. The accuracy was specified at $0.5 \%$ of full-scale capacity. Each load cell contains three vibrating wire strain gages, the output

${ }^{2} \# 9$ rebar refers to rebar with a diameter approximately $9 / 8$ of an inch. 


\section{Table 2-3. Location and Type of Instumented Rockbolts}

\begin{tabular}{|c|c|c|c|c|c|c|c|c|}
\hline $\begin{array}{l}\text { NRST } \\
\text { Station* } \\
\text { (m) }\end{array}$ & $\begin{array}{l}\text { Alcove No. } 1 \\
\text { Station }^{\dagger} \\
\text { (m) }\end{array}$ & $\begin{array}{l}\text { Construction } \\
\text { Reference }^{\ddagger}\end{array}$ & $\begin{array}{c}\text { Type of } \\
\text { Bolt } \\
\end{array}$ & $\begin{array}{c}\text { Type of } \\
\text { Instrument }\end{array}$ & $\begin{array}{l}\text { Length } \dagger \dagger \\
\text { (m) }\end{array}$ & $\begin{array}{c}\text { Diameter } \dagger \dagger \\
(\mathbf{m m})\end{array}$ & $\begin{array}{c}\text { No. of } \\
\text { Instruments }\end{array}$ & $\begin{array}{c}\text { Bolts Pull } \\
\text { Tested } \dagger \dagger \\
(\mathbf{k N}) \\
\end{array}$ \\
\hline $0+00 \mathrm{~m}$ & N/A & Highwall $1,9,10$ & Grouted & RBLC & $3,6.1$ & $22.2,28.6$ & 3 & NT \\
\hline $0+16.8 \mathrm{~m}$ & N/A & $\mathrm{R} 9 \mathrm{C}, 2 \mathrm{R}, 1 \mathrm{~L}$ & Grouted & RBLC & $3,4.9$ & $22.2,28.6$ & 3 & $111.2,249.1$ \\
\hline $0+27.4 \mathrm{~m}$ & N/A & $\mathrm{R} 16 \mathrm{C}, 3 \mathrm{R}, 2 \mathrm{~L}$ & Grouted & RBLC & $3,4.9$ & $22.2,28.6$ & 3 & $111.2,249.1$ \\
\hline $0+33.5 \mathrm{~m}$ & N/A & $\mathrm{R} 20 \mathrm{IR}, 3 \mathrm{R}, 2 \mathrm{~L}$ & Grouted & RBLC & $4.9,7.3$ & 28.6 & 3 & 249.1 \\
\hline $0+42.7 \mathrm{~m}$ & N/A & $\mathrm{R} 26 \mathrm{C}, 2 \mathrm{R}, 3 \mathrm{~L}$ & Grouted & RBLC & 4.9 & 28.6 & 3 & 249.1 \\
\hline $0+56.3 \mathrm{~m}$ & N/A & $\mathrm{R} 35 \mathrm{C}, 2 \mathrm{R}, 2 \mathrm{~L}$ & Grouted & RBLC & 4.9 & 28.6 & 3 & 249.1 \\
\hline $0+42.7 \mathrm{~m}$ & $0+4.6 \mathrm{~m}$ & N/A & Point Anchored & IRB & 3 & 19.0 & 2 & $\mathrm{NT}^{* *}$ \\
\hline $0+42.7 \mathrm{~m}$ & $0+11.6 \mathrm{~m}$ & N/A & Point Anchored & IRB & 3 & 19.0 & 1 & NT \\
\hline $0+42.7 \mathrm{~m}$ & $0+14.0 \mathrm{~m}$ & N/A & Point Anchored & IRB & 3 & 19.0 & 1 & NT \\
\hline $0+42.7 \mathrm{~m}$ & $0+17.7 \mathrm{~m}$ & N/A & Point Anchored & IRB & 3 & 19.0 & 1 & NT \\
\hline $0+42.7 \mathrm{~m}$ & $0+23.8 \mathrm{~m}$ & N/A & Point Anchored & IRB & 3 & 19.0 & 1 & NT \\
\hline \multicolumn{9}{|c|}{$\begin{array}{l}\text { Measured from Portal } 0+00 \mathrm{~m} \text { increasing westward. } \\
\text { † Measured from NRST centerline increasing northward. } \\
\text { †RST rockbolts installed in "rings" (R) containing a center (C) bolt, } 4 \text { bolts left (L), and } 4 \text { bolts right (R) of centerline. } \\
\text { ** Not tested - NT. } \\
\text { †† Preliminary }\end{array}$} \\
\hline
\end{tabular}




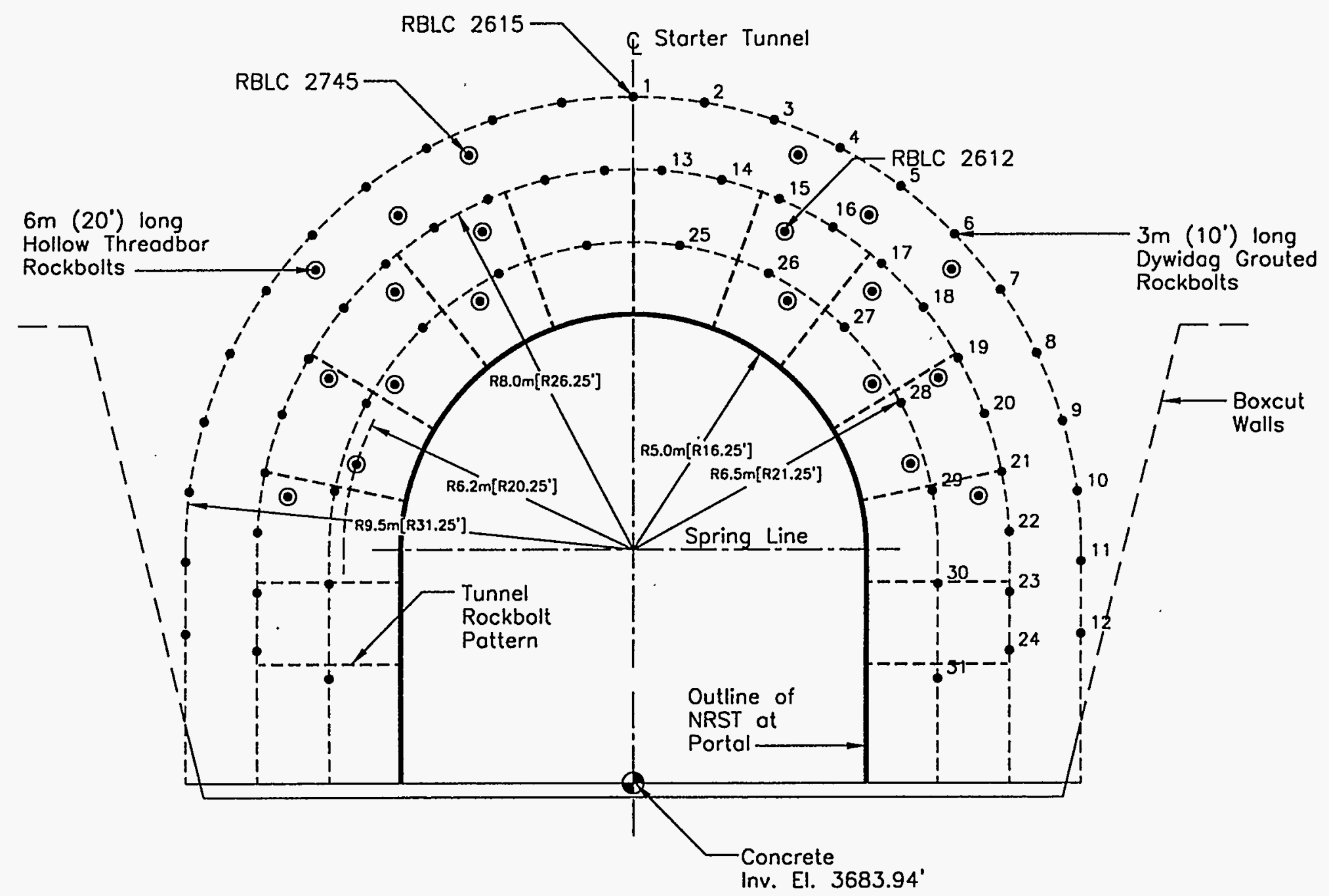

Figure 2-8. Schematic of rockbolt pattern on the portal face (highwall), showing the locations of the RBLCs looking northwest (from ESF Package 1A, YMP-025-1-MING-MG137, Rev 2). 
Rev 1

Typical hollow core pumpable cementgrouted $3048 \mathrm{~mm}$ (10 ft) nominal rockbolt

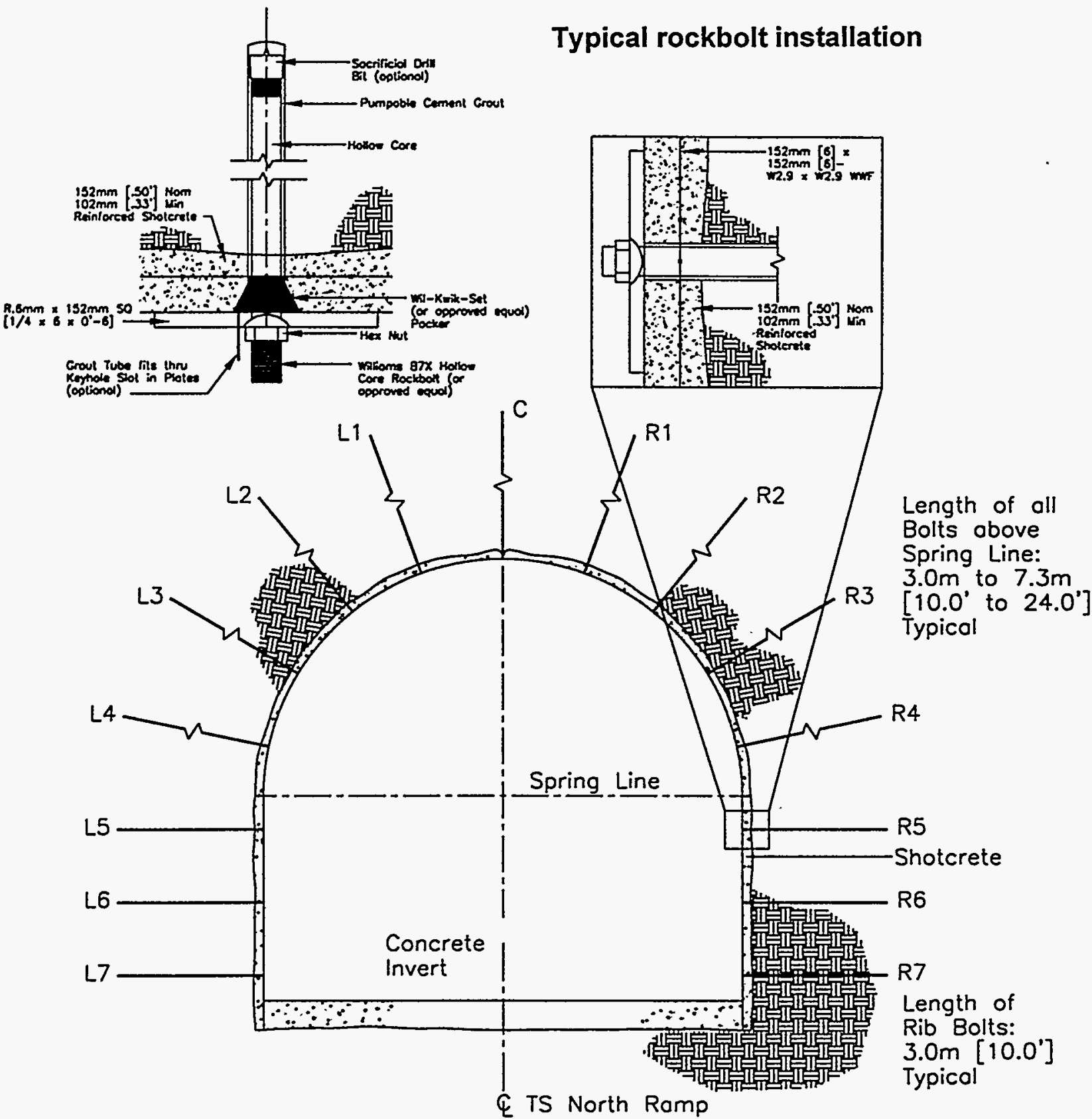

Figure 2-9. General cross section of the NRST showing pattern of grouted rockbolts installed for final support (from ESF Package 1A, YMP-025-1-MING-MG143, Rev 3). 
of which is summed and used to calculate the total load. The three transducers allow for nonuniform loading of the load cell at the rough perimeter of the tunnel. The bolts were installed on extensions that allowed attachment through the hollow load cell loaded against a steel bearing plate.

Instrumented rockbolts (IRBs), installed in Alcove No. 1, were Roctest model IRB-H10. The bolts were 19-mm (3/4-in) diameter high-strength steel (1060) with 32-mm (11/4-in) expansion shell anchors set at a nominal depth of $3 \mathrm{~m}(10 \mathrm{ft})$. The IRB is instrumented with a single vibrating wire transducer placed in a 6.4-mm (1/4-in) hole drilled in the center of the bolt head. The transducer is secured in the hole by set screws.

\subsubsection{Tunnel Stability Monitoring}

Stability monitoring instrumentation in the tunnel and Alcove No. 1 consisted of both convergence measurements and borehole extensometers. Both single- and multi-point borehole extensometers (MPBXs) were installed; convergence was measured using a tape extensometer.

2.3.4.1 Convergence Monitoring. Arrays of convergence points were installed in the tunnel at five stations $(0+16.8 \mathrm{~m}, 0+27.4 \mathrm{~m}, 0+33.5 \mathrm{~m}, 0+42.7 \mathrm{~m}$, and $0+56.4 \mathrm{~m})$, corresponding to the locations of the rockbolt load cells. An additional station was installed just past the end of the girders at $0+11 \mathrm{~m}$. The convergence point layout within the tunnel cross section was identical to that of the portal girders. Only vertical and horizontal cords were established in the alcove. Figure 2-10 illustrates the arrangement of convergence points for both the main tunnel and the alcove. 
Rev 1

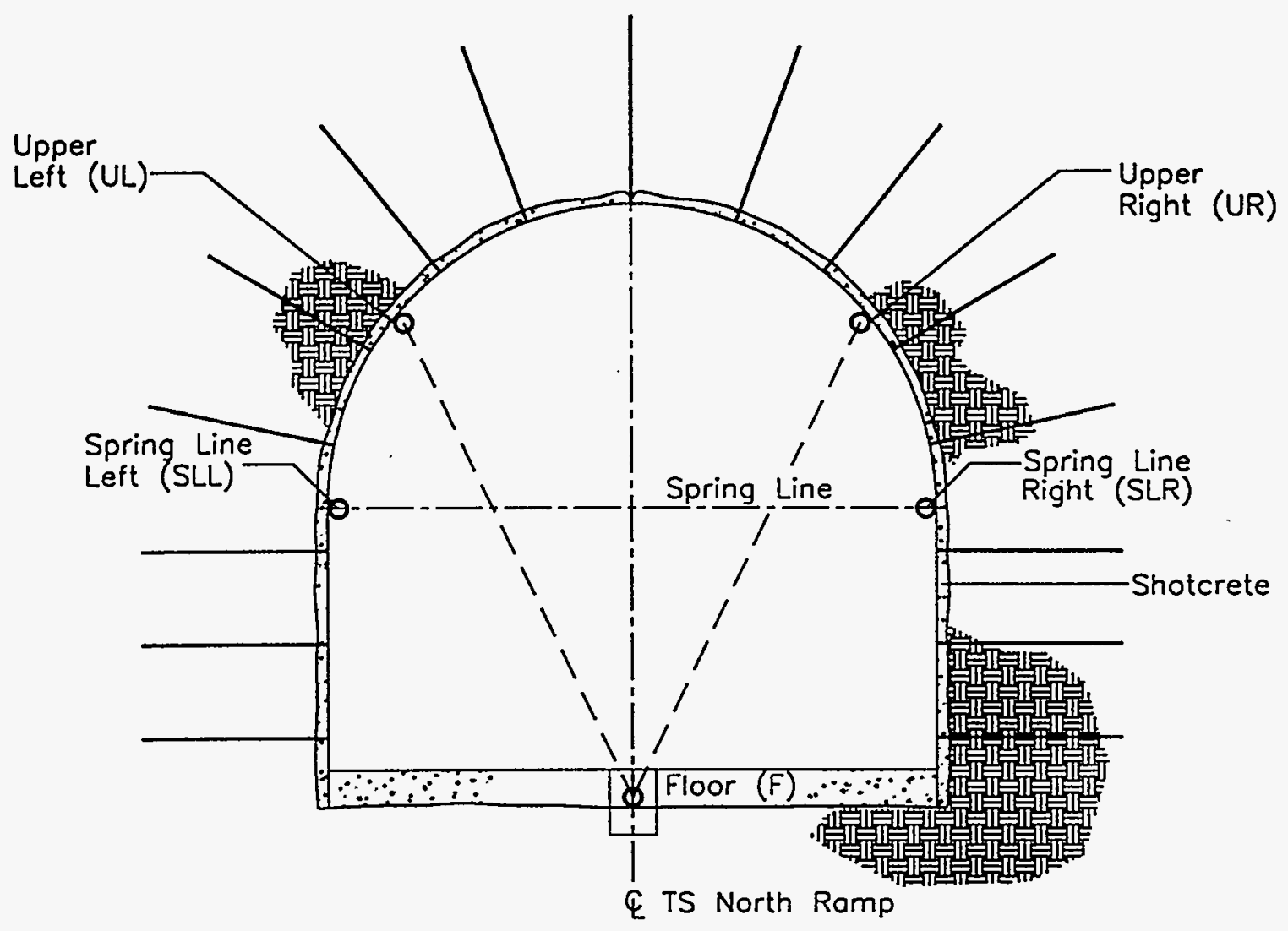

Main Tunnel, looking northwest.

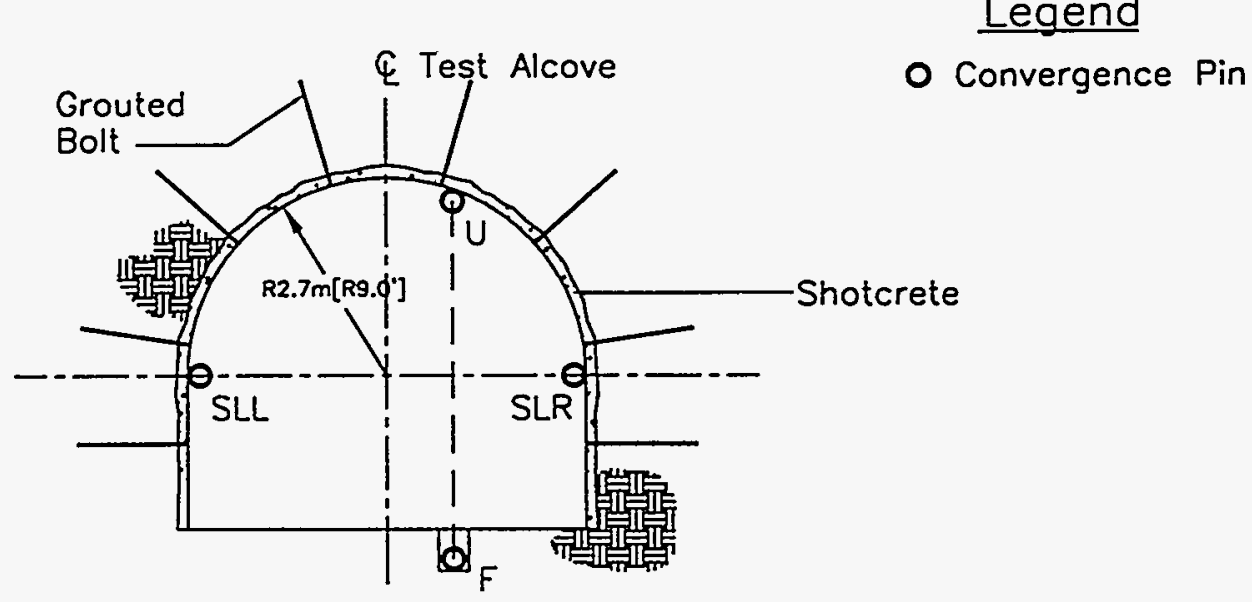

Alcove No. 1, looking north.

Figure 2-10. General convergence pin layout for the Main Tunnel and Alcove No. 1. 
The convergence points consisted of eyebolts anchored in a 150-mm (6-in) length of \#7

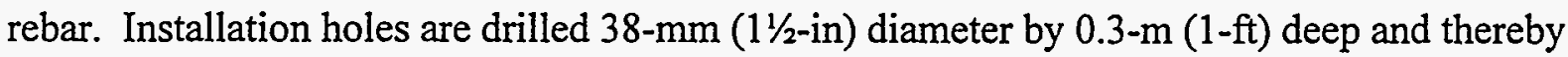
countersunk 76-mm (3-in) diameter for 76-mm ( 3 in) to allow the eyebolt to be recessed and protected from damage. The rebars were grouted in place using cementitious grout. Floor points were grouted $0.3-0.6 \mathrm{~m}(1-2 \mathrm{ft})$ into the rock through steel pipes set in holes drilled in the concrete floor. Steel covers were installed to protect the floor pins from damage.

Convergence stations installed in Alcove No. 1 consisted of vertical and horizontal chords as shown in Figure 2-10. The vertical chord was offset from the alcove centerline to accommodate the ventilation duct. Alcove No. 1 convergence stations were nominally placed at North Ramp station $0+42.7 \mathrm{~m}$ and Alcove No. 1 stations $0+4.6 \mathrm{~m}, 0+11.3 \mathrm{~m}, 0+17.7 \mathrm{~m}$, and 0+24.4 m increasing north from the North Ramp centerline.

2.3.4.2 Borehole Extensometers. Three MPBXs were installed at stations in the main tunnel, and one MPBX was installed in Alcove No. 1. In addition, two single-point borehole extensometers (SPBX) were installed in Alcove No. 1. Table 2-4 lists the station, orientation, and anchor depths for each of the NRST extensometers. Figure 2-11 shows the typical arrangements of the extensometers within the cross section of both the NRST main tunnel and Alcove No. 1.

All extensometers were Geokon model A5 equipped with model 4450-5 vibrating wire displacement transducers. Borros-type hydraulic anchors were inserted into the boreholes on stainless steel rods. The Borros anchor was used because the large lithophysae that occur in the Tiva Canyon upper lithophysal zone made the borehole diameter very irregular. The anchor had the capability of expanding to $0.3 \mathrm{~m}(1 \mathrm{ft})$ to accommodate the borehole irregularity. 
Rev 1

Table 2-4. Location, Orientation, and Anchor Depths for NRST Extensometers

North Ramp Alcove Type

Station* $^{*}(\mathrm{~m})$ Station $^{\dagger}(\mathrm{m})$ $0+42.7$

-

(n)

$\begin{array}{cc}\text { Type } & \text { Orientation } \\ \text { MPBX } & \text { Vertical up }\end{array}$

Anchor Nominal Anchor

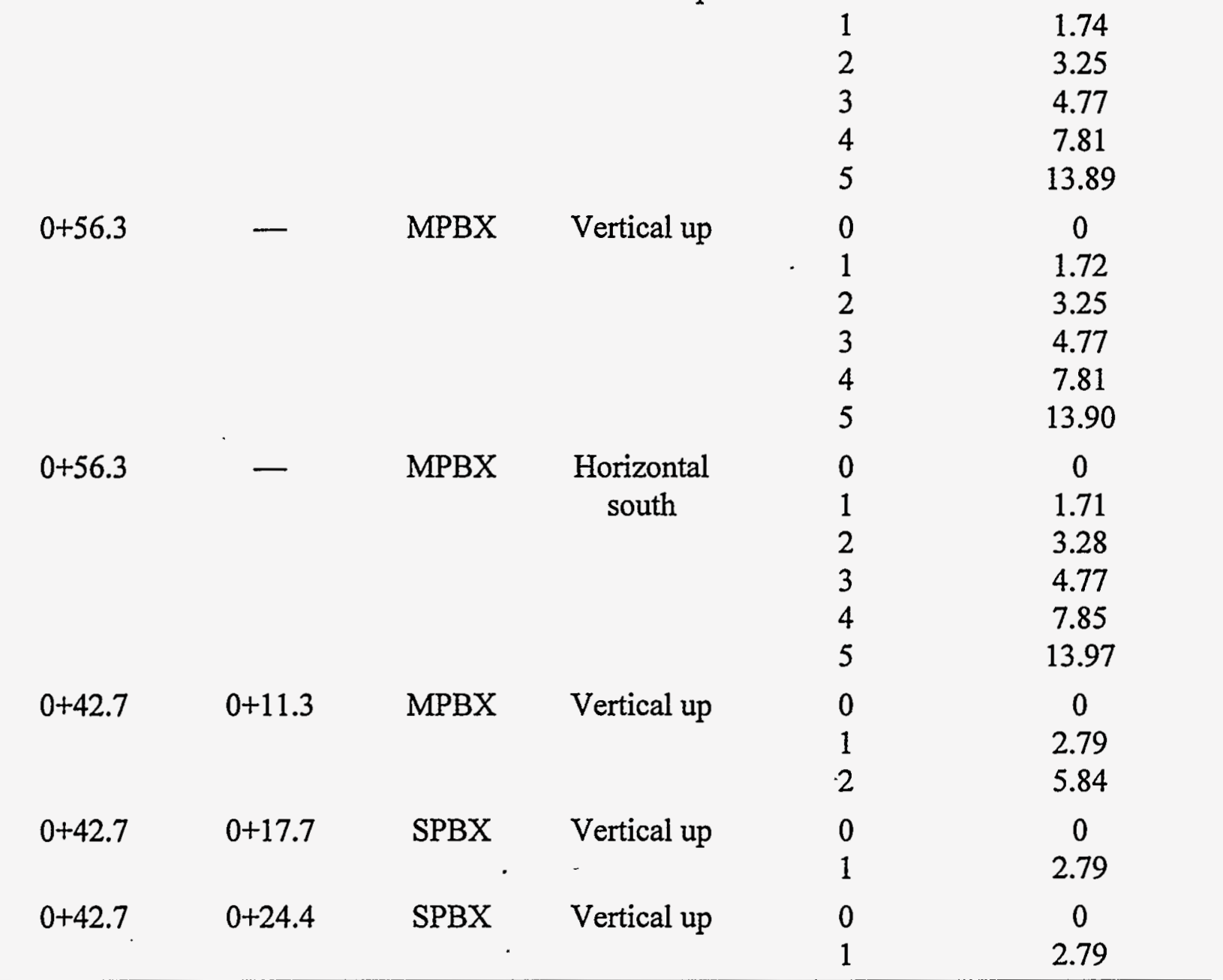

* From Portal 0+00 m.

$\dagger$ From ramp centerline NE along alcove centerline.

$\ddagger$ Anchor No. 0 is the attachment for instrumented head at the borehole collar. 
SAND95-1675

Rev 1

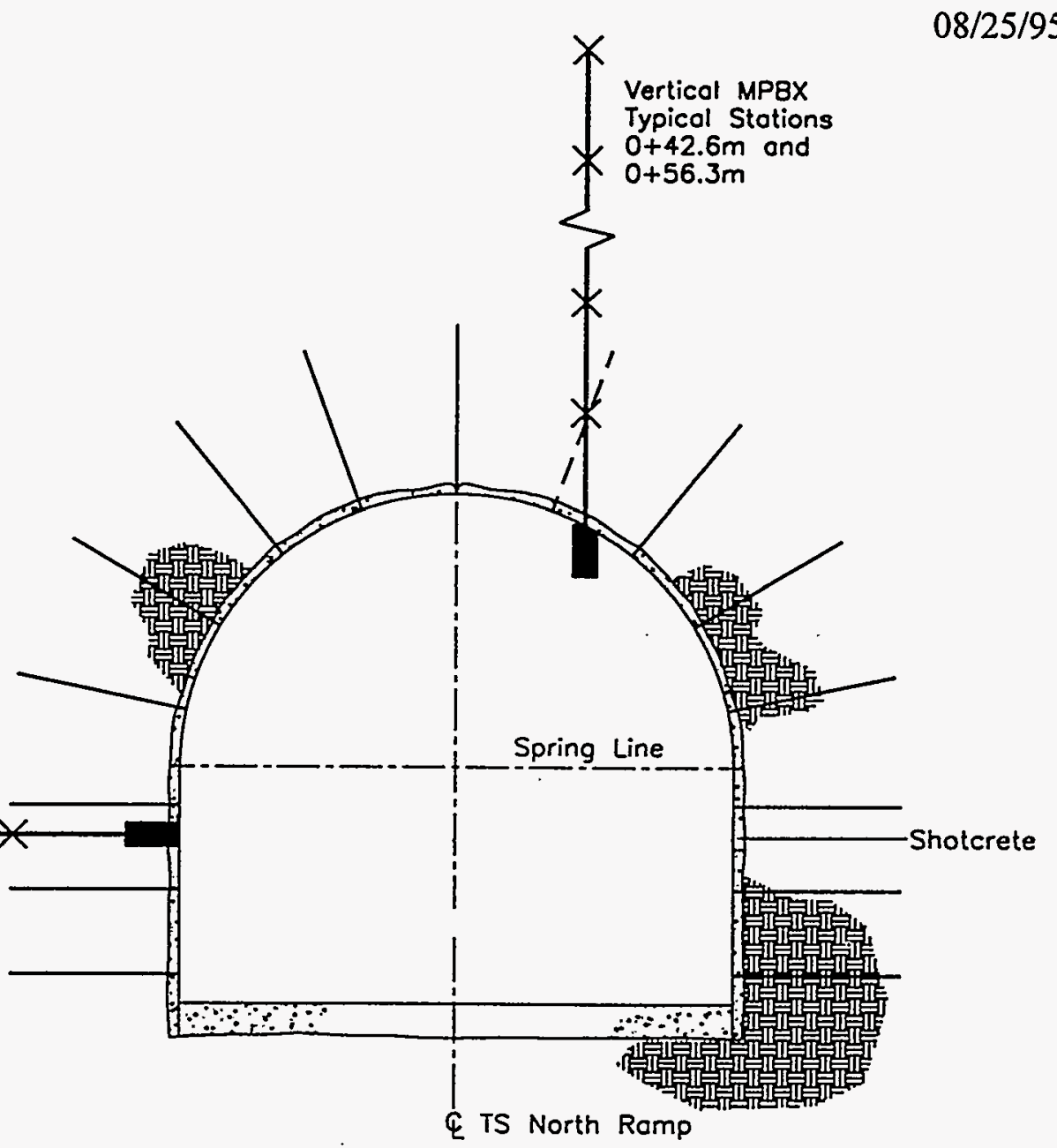

NRST Main Tunnel, looking northwest.

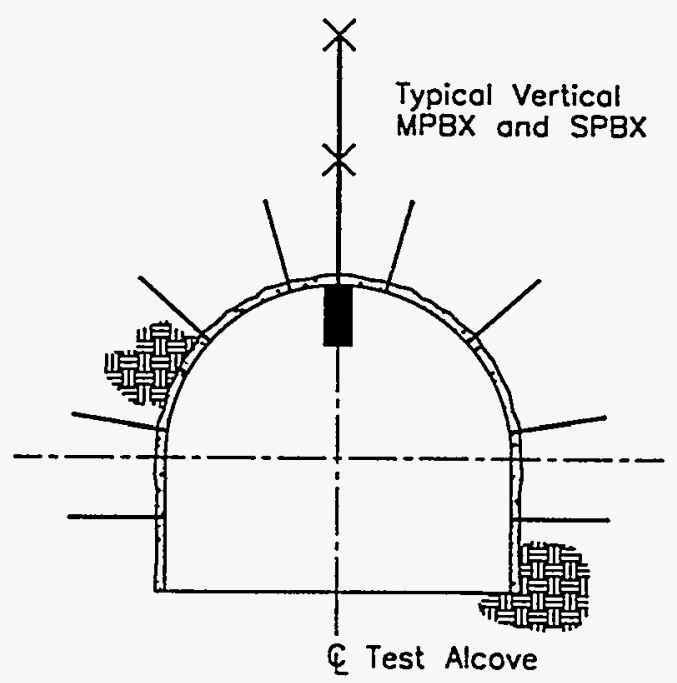

Alcove No. 1, looking north.

Figure 2-11. Cross sections of the NRST Main Tunnel and Alcove No. 1 showing typical configurations of the extensometers. 
Rev 1

\subsubsection{Stress Change Monitoring}

Borehole pressure cells (BHPCs) were installed to measure stress change in rock at the end of the NRST as the TBM excavated past the pressure cells. The BHPCs were installed in three holes drilled radially from the end of the NRST as shown in Figure 2-12, a schematic of the end of the NRST. The BHPCs were installed in three boreholes at different distances from the planned bored wall to be excavated by the TBM. Two BPHCs were placed in each borehole and were oriented to measure changes in the vertical stress and horizontal stress, respectively.

The borehole pressure cells are small flatjacks $51 \mathrm{~mm}(2 \mathrm{in})$ wide by $210 \mathrm{~mm}$ ( $8.25 \mathrm{in})$ long by $6.4-\mathrm{mm}(1 / 4-$ in) thick. These BHPCs, Geokon Model 3200, were precast in grout cylinders. The grout cylinders were then placed at the desired depths in the boreholes, oriented in the boreholes, and then grout was pumped into the boreholes to produce tight contact with the borehole walls. Geokon Model $4500 \mathrm{H}$ vibrating wire pressure transducers were used to monitor the flatjack pressure. After grouting the BHPCs, a concrete structure was constructed to aid the TBM in sumping into the face. This structure is shown in Figure 2-12.

The configuration of the individual BHPCs within each hole are listed in Table 2-5. The BHPCs were grouted on June 24, 1994. The grout was allowed to cure until August 3, 1994, then the BHPCs were pressurized to $0.724-0.759 \mathrm{MPa}(105-110 \mathrm{psi})$. The initial pressures are listed in Table 2-5. The pressurized flatjacks bled-off with time and were re-pressurized on October 4, 1994, during the TBM start-up and mining by the BHPCs. Applied pressure ranged from 1.035-1.279 MPa (150-200 psi) and the initial re-pressure levels are listed in Table 2-5. 
SAND95-1675

Rev 1
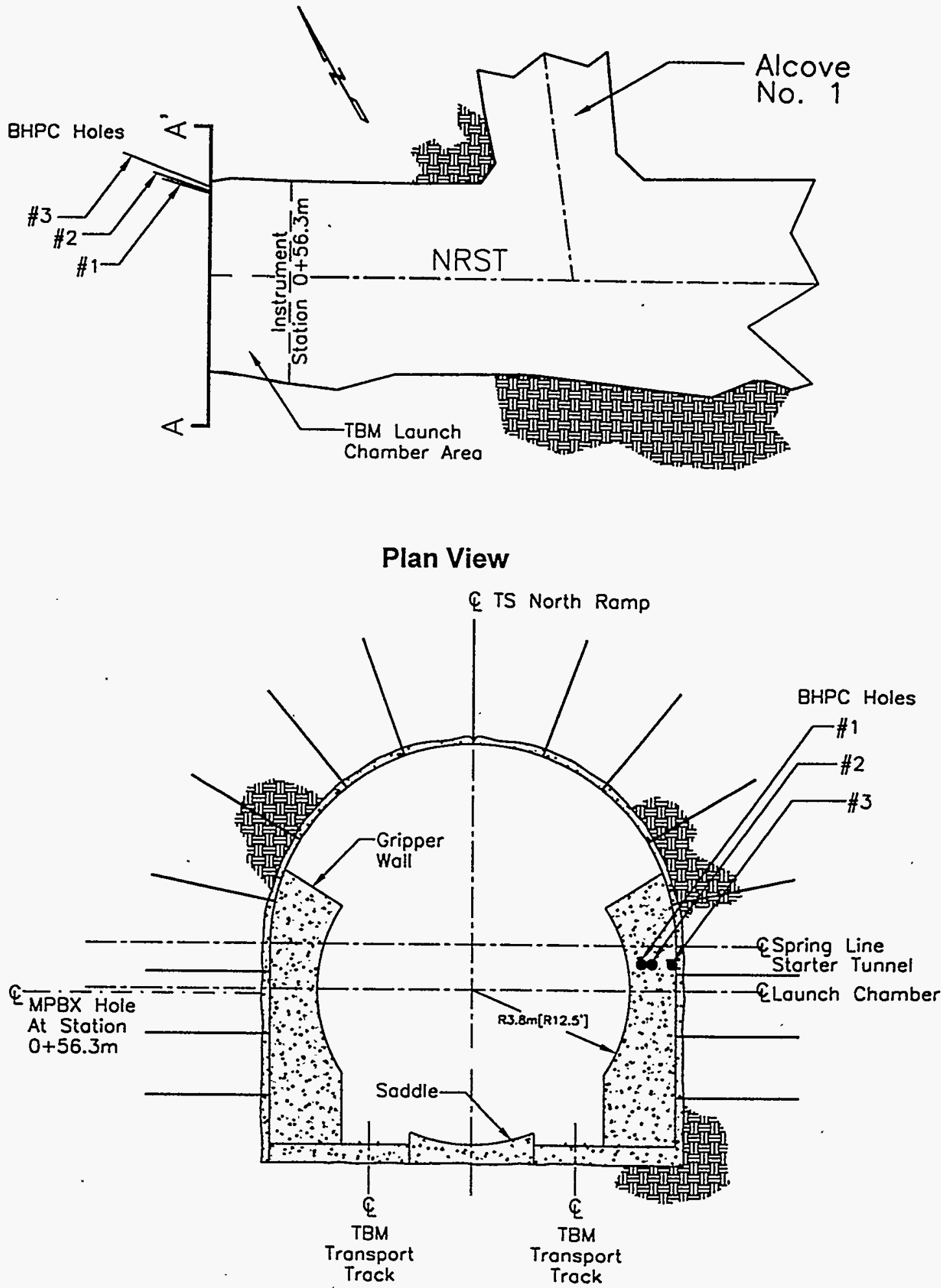

Cross Section A-A', looking northwest.

Figure 2-12. Schematic showing configuration of the TBM launch chamber in the NRST and location of the borehole pressure cells. 


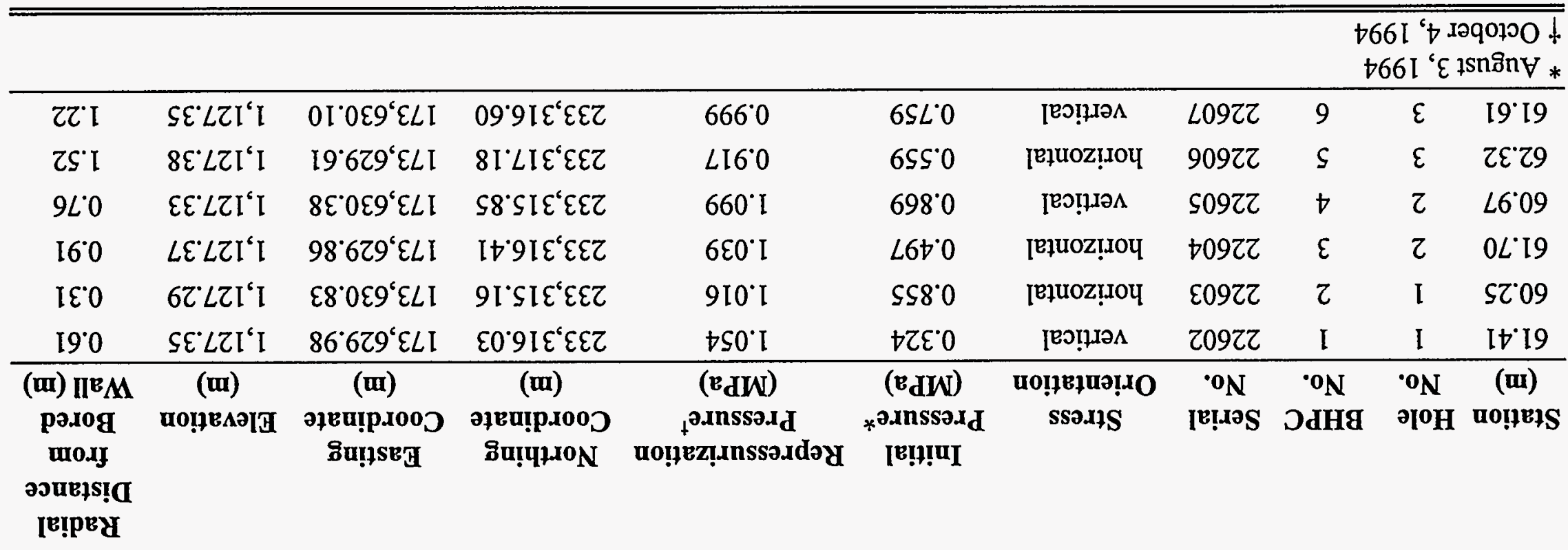




\subsection{Data Acquisition and Analysis}

\subsubsection{Manual Instrument Reading}

Instruments were read manually at installation and for the period up to April 30, 1994, when installation of the data acquisition system was complete. Convergence measurements were made using a Terrametrics Model 1600 tape extensometer. Remote reading instruments, with the exception of some temperature sensors, were all based on vibrating wire gages. These instruments were read with a Geokon GK-401 read-out instrument.

\subsubsection{Data Acquisition System}

A computer-based data acquisition system (DAS) was installed in Alcove No. 1 to automate monitoring of all electronic-based instrumentation. The system layout and connectivity is illustrated by the system drawing in Appendix C.

The DAS was designed and configured by Roctest. It was developed around a CR10 Central Measurement and Control Module manufactured by Campbell Scientific, Inc. The CR10 is a fully programmable data logger/controller built in a small, rugged, and sealed module. The CR10 was located in a junction box in the alcove and communicated with six Roctest RTX-248 analog multiplexers which were remotely located at junction boxes J1 through J6 throughout the NRST and Alcove No. 1.

In the normal operating mode, the CR10 reads each instrument four times a day and stores the data. Data were downloaded to a notebook computer on nominally one-month intervals to protect against overwriting. The DAS output is saved as an ASCII file that is 
Rev 1

incrementally updated, then backed up on 3.5-in disks and magnetic tape. These ASCII data are the digitized value of the gage output (generally, in the case of vibrating wire gages, this is the frequency squared of the wire). No manipulation of these ASCII data is permitted beyond updating the file with new data.

The data from the DAS are imported into a duplicate spreadsheet file using a macro program. Once verified, the data were separated by gage into individual spreadsheets.

Calibration factors are input into calculations in the spreadsheet files and the data are plotted for analysis and presentation. 
This page left intentionally blank. 


\subsection{Construction Monitoring Data}

\subsection{Introduction}

The results of the construction monitoring activities are presented in this section of the report. Rock mass quality evaluations are discussed for each of the top headings, bench and Alcove No. 1. Blasting seismic data are organized according to the top heading, and Alcove No. 1 excavations. The instrumentation data are organized by station/location and can be correlated with the USBR structural mapping data by referring to Appendix D.

Although most of the instrumentation was installed after all excavation had been completed, there were several instruments installed during mining. Figure 3-1 presents a historical schedule of events that indicates the interactions of the various data collection activities. Excavation of the main tunnel was initiated in April 1993 and the top heading was completed by mid-July 1993. During this period, rock mass quality assessment and blast monitoring were the main design verification activities performed. Midway through excavation of the top heading, the 6-m (20-ft) long grouted rockbolts were installed in the portal face (highwall) with three of the bolts instrumented in early June, as described in Section 2.3.3.2. The top heading portions of the portal girders were installed in mid-June and the lower portions were completed at the end of November after excavation of the bench. Excavation of the bench and collection of the rock mass quality data occurred between August and early October 1993. The only instrumentation that was in place during mining excavation were the portal face RBLCs, the upper portion of the lattice girder convergence points, and three additional RBLCs installed at station $0+16.8 \mathrm{~m}$. The remaining instruments in the main tunnel were installed between mid-October and mid-December 1993, during installation of the final support. 


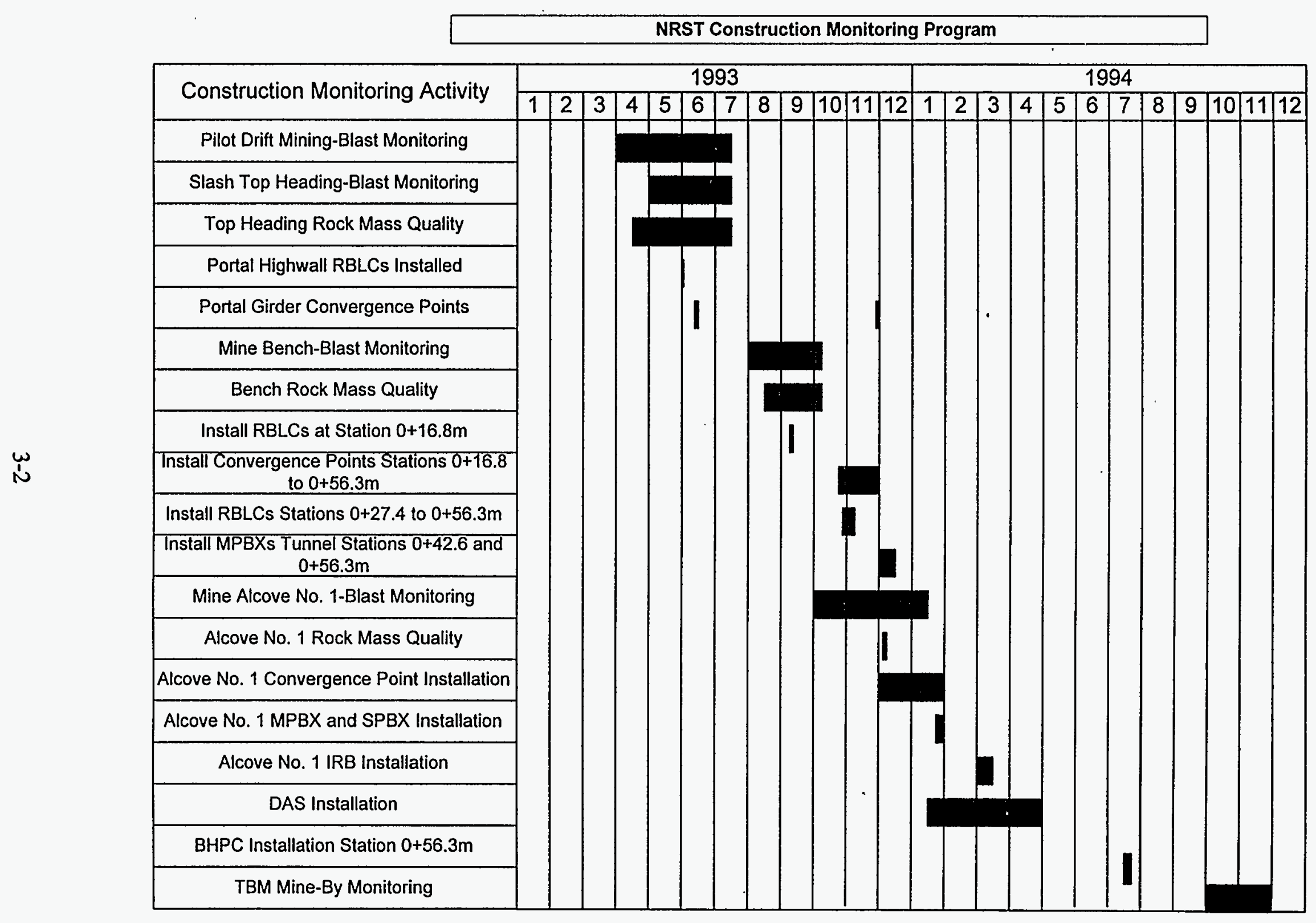

Figure 3-1. Schedule of activities in NRST construction monitoring program. 
Excavation of Alcove No. 1 began early October 1993 and was completed by mid-January 1994. Some convergence points were installed during excavation, however, the extensometers and IRBs were installed after completion of mining and during installation of the final support.

Borehole pressure cells were installed and grouted into boreholes near the end of June 1994. The cells were pressurized at the beginning of August 1994. The TBM was sumped-in to begin boring of the North Ramp near the end of September 1994.

These data are derived from a series of scientific notebooks developed during the report period. The traceability of the data into the subsequent analysis file and TDIFs is presented in Appendix A.

\subsection{Rock Mass Quality Data}

Rock mass quality assessments were conducted using both the $Q$ (Barton et al. 1974) and RMR (Bieniawski 1979) systems. These rock mass quality indices have been utilized as the basis for empirical design of tunnel ground support $(\mathrm{Q})$ and for estimation of rock mass mechanical properties (RMR) in the YMP Drift Design Methodology proposed by Hardy and Bauer (1991). These approaches have also been utilized to project construction conditions along the North Ramp (Brechtel et al. 1995) and as the basis of North Ramp ground support design.

The rock mass quality $Q$ and RMR for assessments performed in the top heading, bench, and Alcove No. 1 are presented in Table 3-1 as a range of the observed conditions. RMR was not evaluated in the top heading. Figures 3-2 and 3-3 graphically compare the range of the assessments as a function of tunnel stationing. The figures include the range of ground support 
Rev 1

Table 3-1. Range of Rock Mass Quality for the NRST

Tunnel

\begin{tabular}{|c|c|c|c|c|c|}
\hline & Location (ft) & $\boldsymbol{Q}_{\min }$ & $Q_{\max }$ & $R M R_{\min }$ & $\boldsymbol{R} M \boldsymbol{R}_{\max }$ \\
\hline \multirow{9}{*}{ 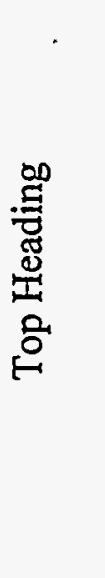 } & $0-10$ & 0.06 & 0.38 & NR & NR \\
\hline & $10-34$ & 0.07 & 0.24 & NR & NR \\
\hline & $34-54$ & 0.15 & 0.48 & NR & NR \\
\hline & $54-72$ & 0.73 & 1.83 & NR & NR \\
\hline & $72-95$ & 0.17 & 0.86 & NR & NR \\
\hline & $97-115$ & 0.68 & 2.80 & NR & NR \\
\hline & $116-129$ & 0.66 & 1.80 & NR & NR \\
\hline & $129-160$ & 0.97 & 2.28 & NR & NR \\
\hline & $160-195$ & 0.31 & 4.40 & NR & NR \\
\hline \multirow{5}{*}{$\begin{array}{l}\stackrel{5}{0} \\
\stackrel{0}{0} \\
\infty\end{array}$} & $2-40$ & 0.05 & 0.24 & 34 & 61 \\
\hline & $40-85$ & 0.63 & 1.32 & 34 & 62 \\
\hline & $85-140$ & 0.37 & 17.40 & 45 & 68 \\
\hline & $140-172$ & 0.37 & 17.40 & 45 & 68 \\
\hline & $172-194$ & 0.16 & 7.60 & 37 & 61 \\
\hline 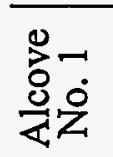 & $28-88$ & 0.36 & 2.78 & 30 & 63 \\
\hline
\end{tabular}

categories derived from the empirical ground support design charts developed by Barton et al. (1974) (see Appendix F). Length-weighted average values of $Q$ were calculated by

$$
\bar{Q}=\log _{10}^{-1}\left[\frac{\Sigma L_{i} \times \log _{10}\left(Q_{i}\right)}{\Sigma L_{i}}\right]
$$

where

$$
\begin{aligned}
& \bar{Q}=\text { length-weighted geometric mean } \\
& L_{i}=\text { length of interval } i \text {, and } \\
& Q_{i}=\text { rock mass quality } Q \text { for interval } i .
\end{aligned}
$$

These values and the range are summarized in Table 3-2. 
Rev 1

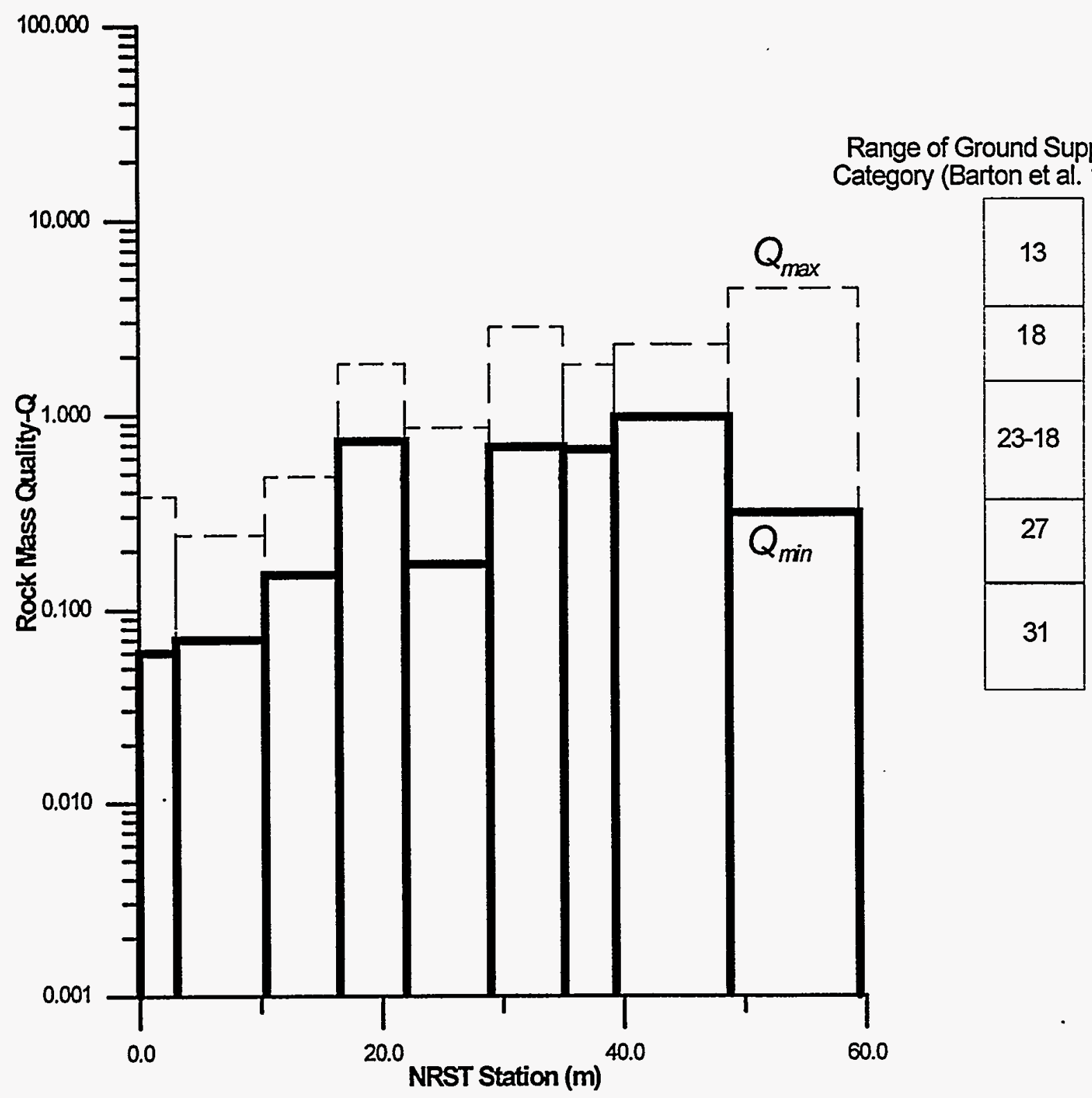

Figure 3-2. Variation of $Q_{m i n}$ and $Q_{\max }$ with NRST station for the Main Tunnel-Top Heading (see Appendix $F$ for definition of ground support categories in Barton et al. 1974). 
SAND95-1675

$\operatorname{Rev} 1$

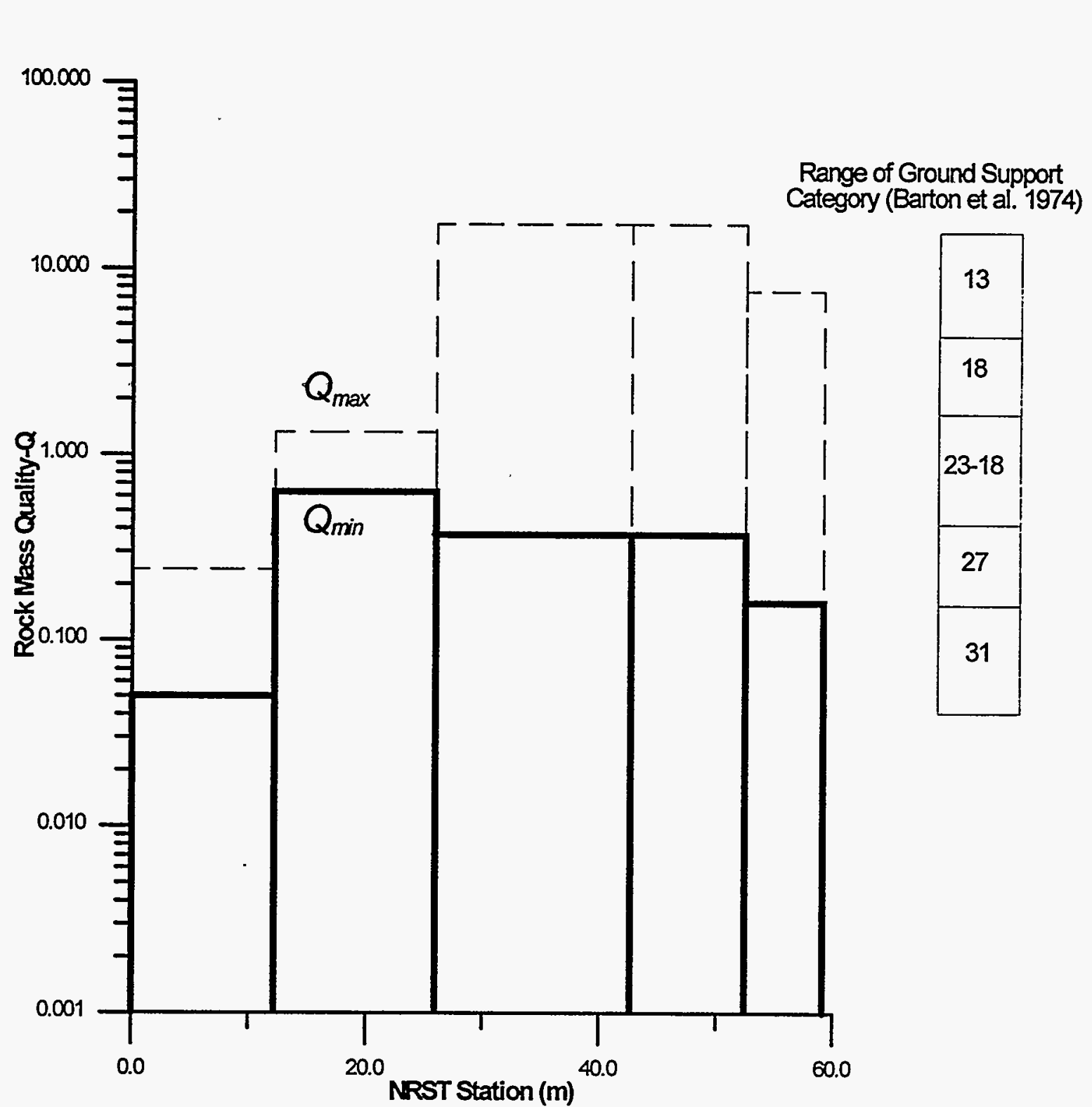

Figure 3-3. Variation of $Q_{\min }$ and $Q_{\max }$ with NRST station for the Main Tunnel bench (see Appendix $F$ for definition of ground support categories in Barton et al. 1974).

\begin{tabular}{lcccc}
\hline \hline \multicolumn{5}{l}{ Table 3-2. Length-Weighted Log Mean Values of $Q_{\min }$ and } \\
$Q_{\max }-$ NRST Main Tunnel \\
NRST Section & Range $Q_{\min }$ & $\bar{Q}_{\min }$ & Range $Q_{\max }$ & $\bar{Q}_{\max }$ \\
\hline Top Heading & $0.06-0.97$ & 0.30 & $0.38-2.80$ & 1.06 \\
Bench & $0.05-0.63$ & 0.24 & $0.24-17.40$ & 1.82 \\
Alcove No. 1 & NM $^{*}$ & 0.36 & NM & 2.78 \\
\hline
\end{tabular}

*NM-Alcove included in one assessment. 
The tables and figures indicate a general trend for increasing rock mass quality with increased depth of NRST penetration from the portal face. This was due to increased distance from the source of weathering and the gradual cross cutting of the Tiva Canyon upper lithophysal zone which correlated with a gradual reduction in size of the lithophysae that occurred at the bottom of the zone. This change is clearly shown by the two high values of $Q(17.40)$ in the bench excavation near the end of the NRST.

The variation of the individual parameters used to determine $Q$ are shown as frequency of occurrence histograms in Figure 3-4, where all data from the NRST have been grouped together. The $Q_{\min }$ data are impacted by the presence of near-vertical shear zones/broken zones that have undergone relatively small movements. These zones were localized but impacted overbreak and ground support requirements locally. The $\mathrm{Q}_{\max }$ values are representative of the character of the rock between these larger near-vertical structures.

Length-weighted average values of RMR for the bench were 39.4 and 64.4 for the $R M R_{\text {min }}$ and $R M R_{\max }$, respectively.

\subsection{Blast Monitoring}

The seismic records of the blasting events provided several types of information that were useful in assessing performance. The analog records of the data allowed individual events to be correlated with the delays used to detonate groups of holes. This allowed the construction of correlations between scaled distance and PPV, which could be compared with other data to assess comparable performance. It also provided a basis for adjusting the design of the blast to reduce PPV at any given delay. PPVs were derived directly from the seismic records and correlated with details on charge weight and blasting delays taken from blasting records 


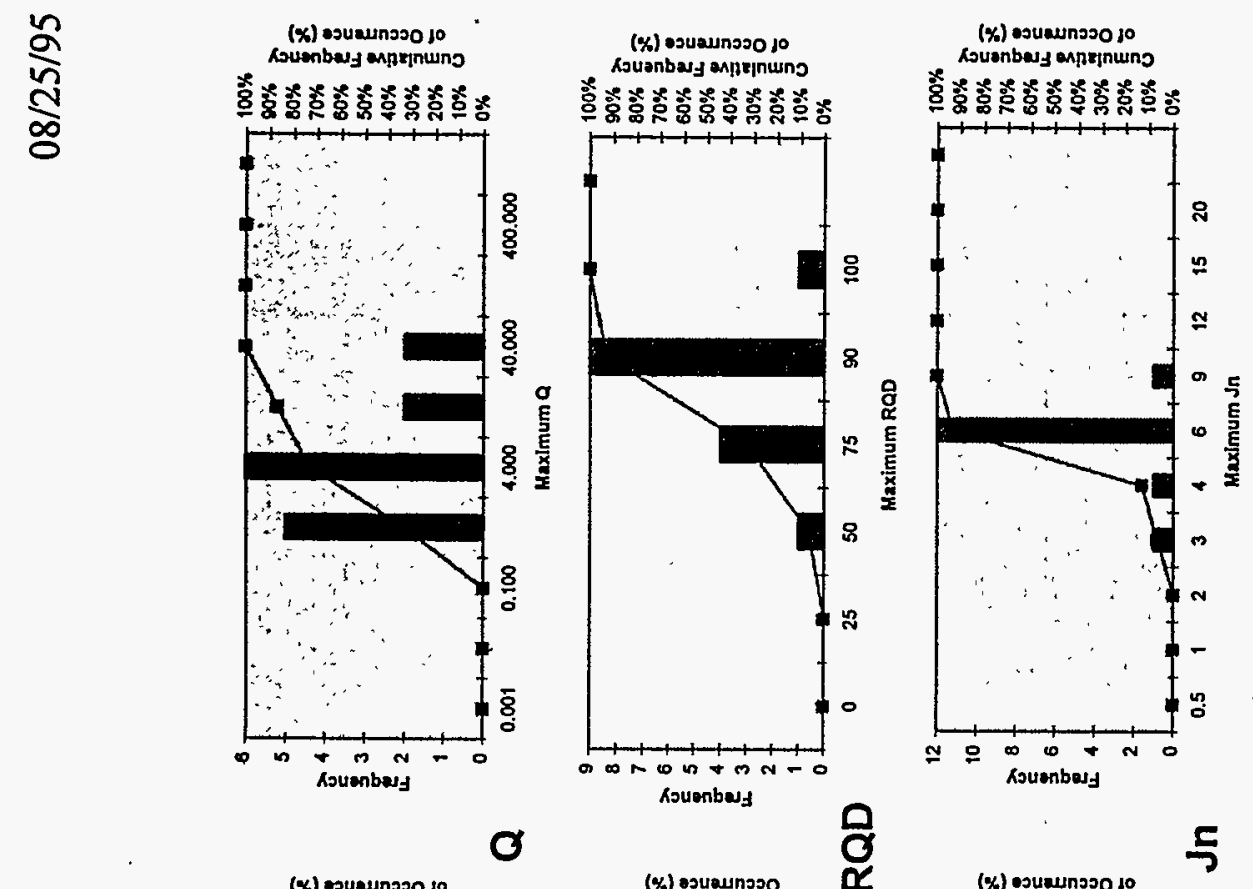

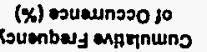

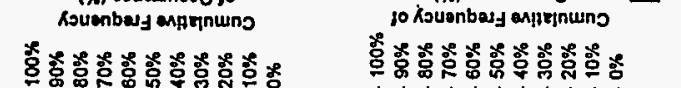
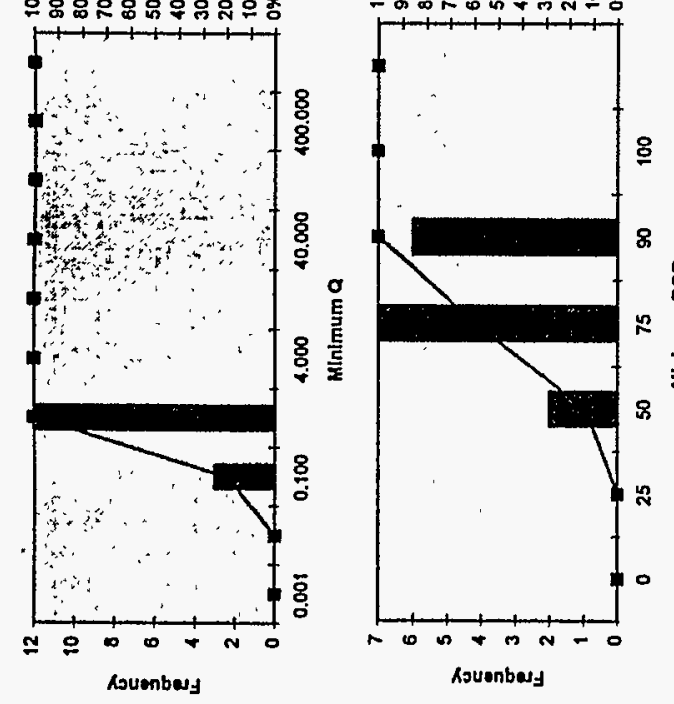

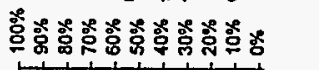
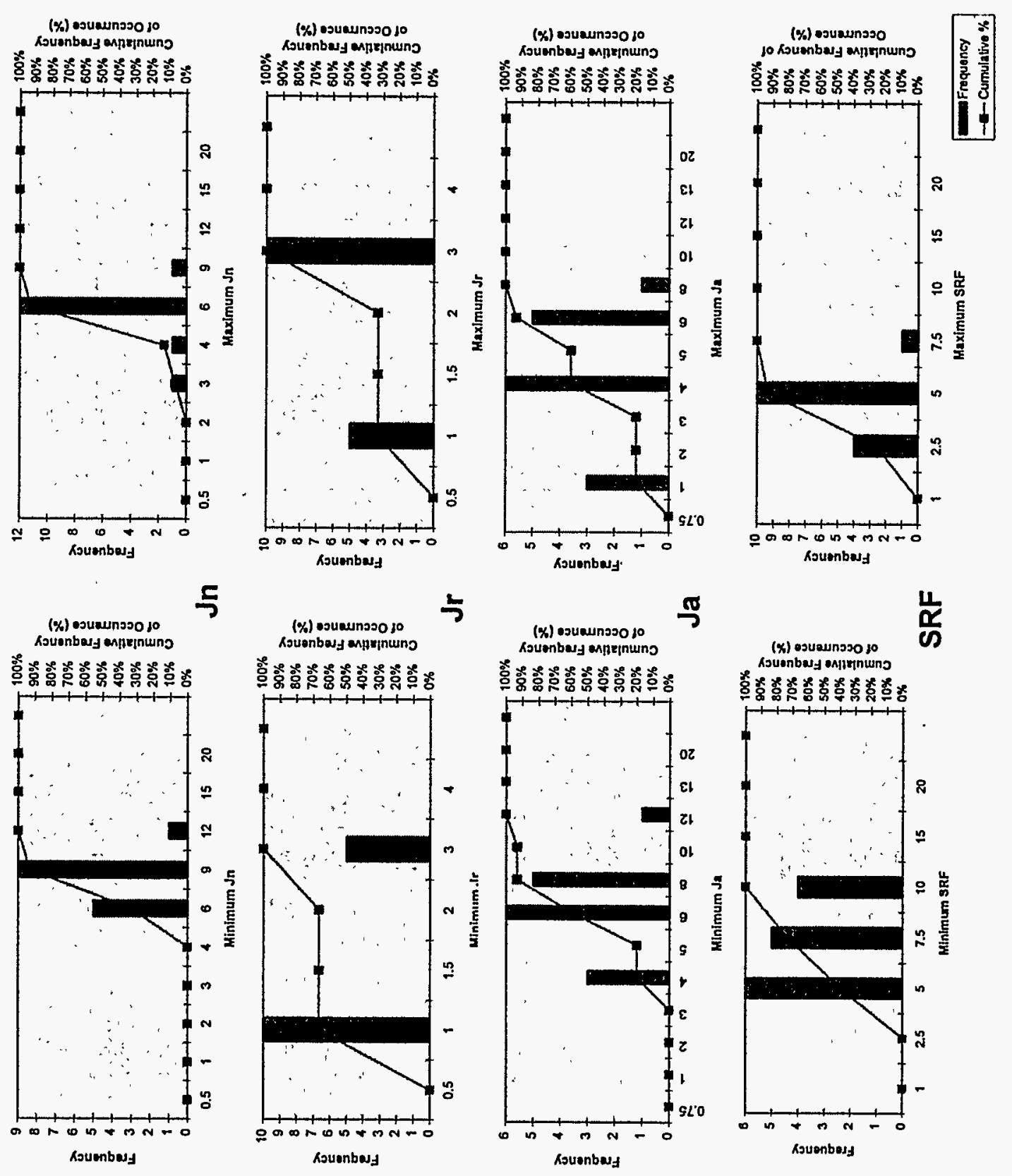

.

$0^{\frac{5}{2}}$
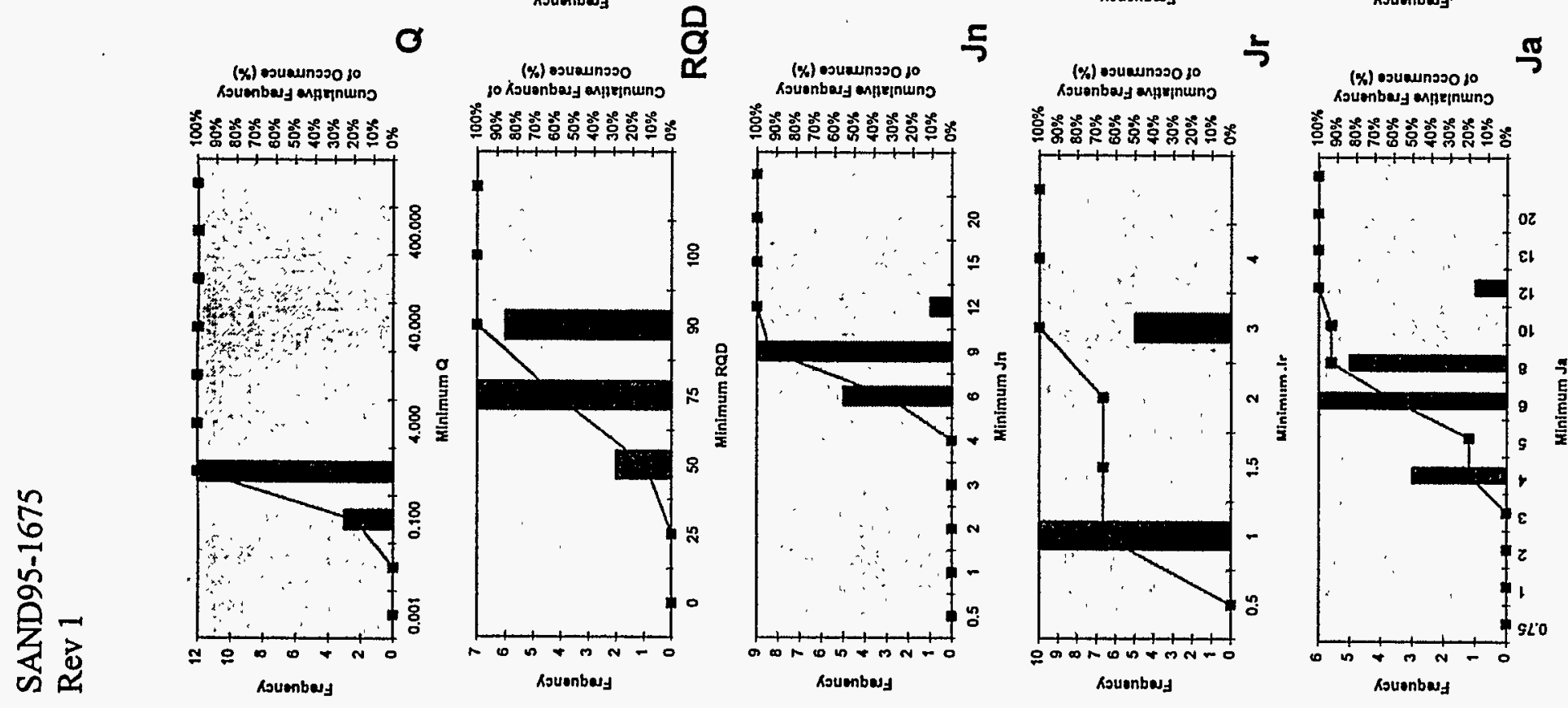

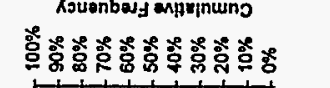
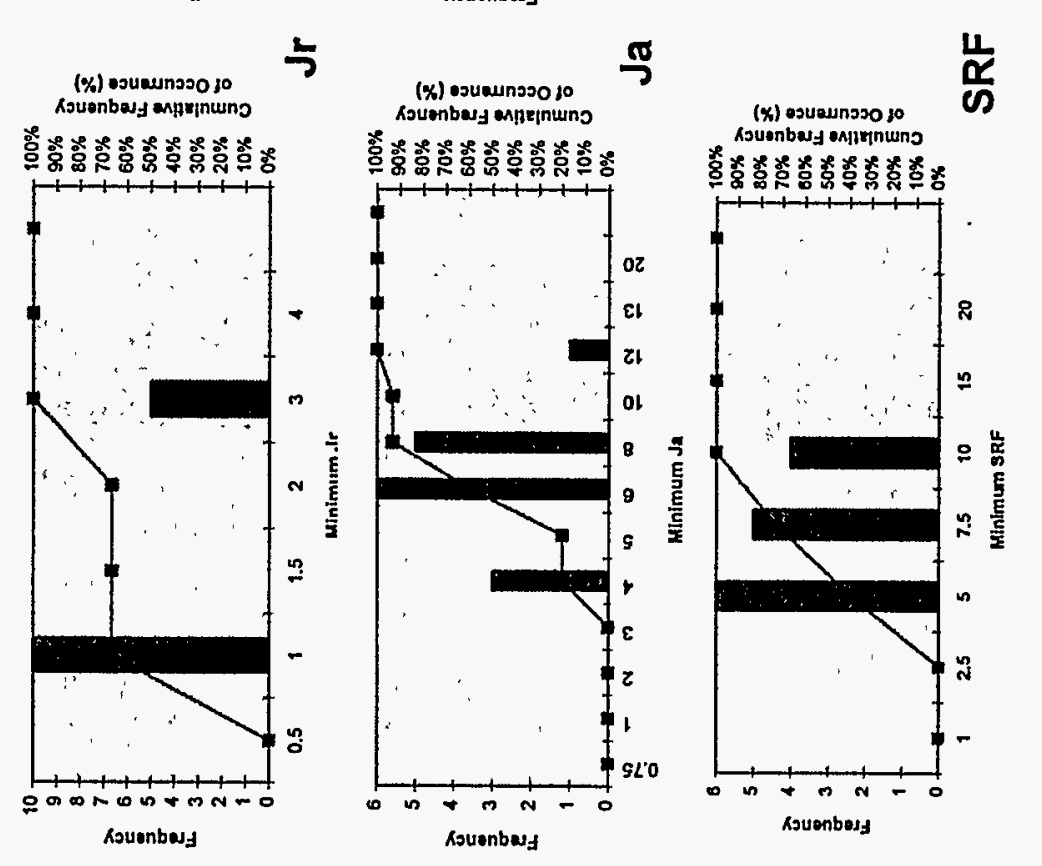
Rev 1

maintained by the constructor, REECo. These data were derived for the top heading blasting events and the Alcove No. 1 blasting experiments. Data recorded in the bench mining were similar in PPV magnitude, peak frequency and distance, but were not included in the analysis.

\subsubsection{Scaled Distance Results for NRST Top Heading Blasting}

The scaling of distance is used to develop attenuation relationships between PPV and distance, when both the distance and weight of explosive detonated are varied. The two most common approaches divide the distance by the square root and cube root of explosive weight, respectively.

The attenuation relationship is calculated by Equations 3-2 and 3-3 for the two different scaling approaches (Dowding 1985).

$$
\begin{aligned}
& P P V=A\left(R / W^{1 / 2}\right)^{B} \\
& P P V=A\left(R / W^{1 / 3}\right)^{B}
\end{aligned}
$$

where

$$
\begin{aligned}
& P P V \quad=\text { peak particle velocity, } \\
& R \quad=\text { distance from seismograph to the blast, } \\
& W \quad=\text { weight of explosive detonated to produce the PPV, and } \\
& A, B \quad=\text { constants. }
\end{aligned}
$$

The two blasting seismic monitors used for recording the top heading blasting were located at five different recording stations as described in Section 2.0. For each blast, the distances between the seismic monitor and the center of the blast were determined using the northing and easting coordinates. Elevations were not considered in calculation of distance. 
Each seismic record consisted of an analog record of the blast and the time that corresponded to the occurrence of the PPV. Using this time of occurrence, the corresponding charge weights were extracted from the blasting records.

Curve fits of PPV versus scaled distance (SD), as calculated by Equations 3-2 or 3-3, were performed using a computer program based on the Simplex algorithm described by Caceci (1984). The results of the curve fit are listed in Table 3-3 and plots of the data and curve fits are presented in Figures 3-5 and 3-6. The numerical data are presented in Appendix E.

$\overline{\text { Table 3-3. Comparison of Curve Fits of PPV versus SD using Equations 3-2 and }}$ 3-3

\begin{tabular}{|c|c|c|c|c|}
\hline \multirow[b]{2}{*}{ Scaling Law } & \multicolumn{2}{|c|}{$\mathrm{PPV}(\mathrm{in} / \mathrm{sec})=\mathrm{A} \times \mathrm{SD}^{\mathrm{B}}$} & \multirow{2}{*}{$\begin{array}{l}\text { Standard } \\
\text { Deviation }\end{array}$} & \multirow[b]{2}{*}{ Estimated Error } \\
\hline & $\mathrm{A}$ & $\bar{B}$ & & \\
\hline $\mathrm{SD}=\mathrm{R} / \mathrm{W}^{1 / 2}$ & 23 & -1.1 & 0.45 & 0.047 \\
\hline $\mathrm{SD}=\mathrm{R} / \mathrm{W}^{1 / 3}$ & 133 & -1.5 & 0.39 & 0.040 \\
\hline
\end{tabular}

Figure 3-5 compares the measured PPV to a general relationship reported by Dupont (1980) to be typical for attenuation of blasting energy with conventional explosives. The relationship is

$$
P P V=160\left(\frac{R}{W^{1 / 2}}\right)^{1.6}
$$

The scatter in the NRST blasting data is typical and the results are grouped around the relationship in Equation 3-4. The difference is due to site-specific conditions and would be expected. 
Rev 1

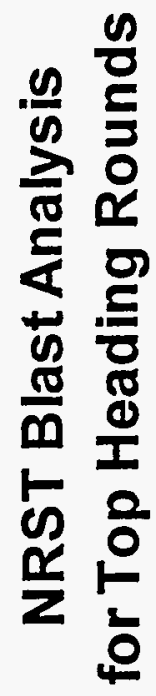

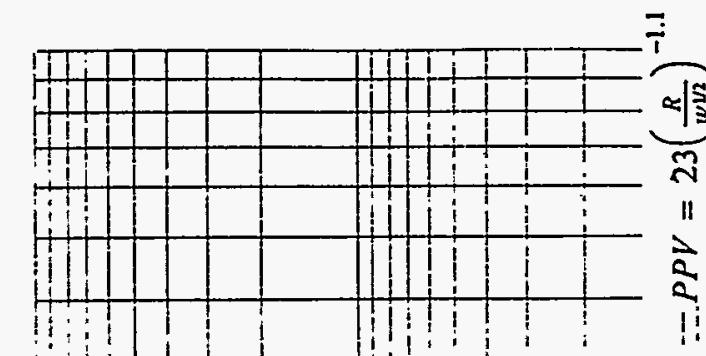

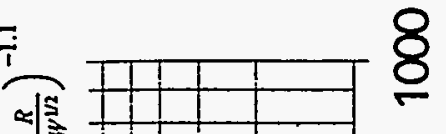

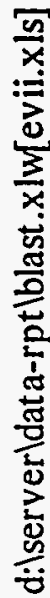

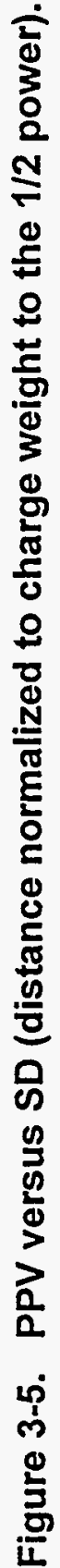

8
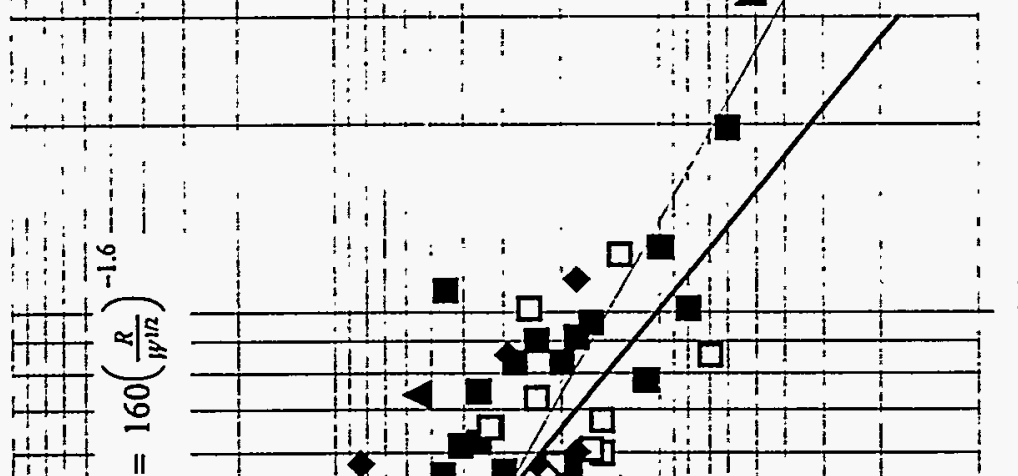

8

余

은
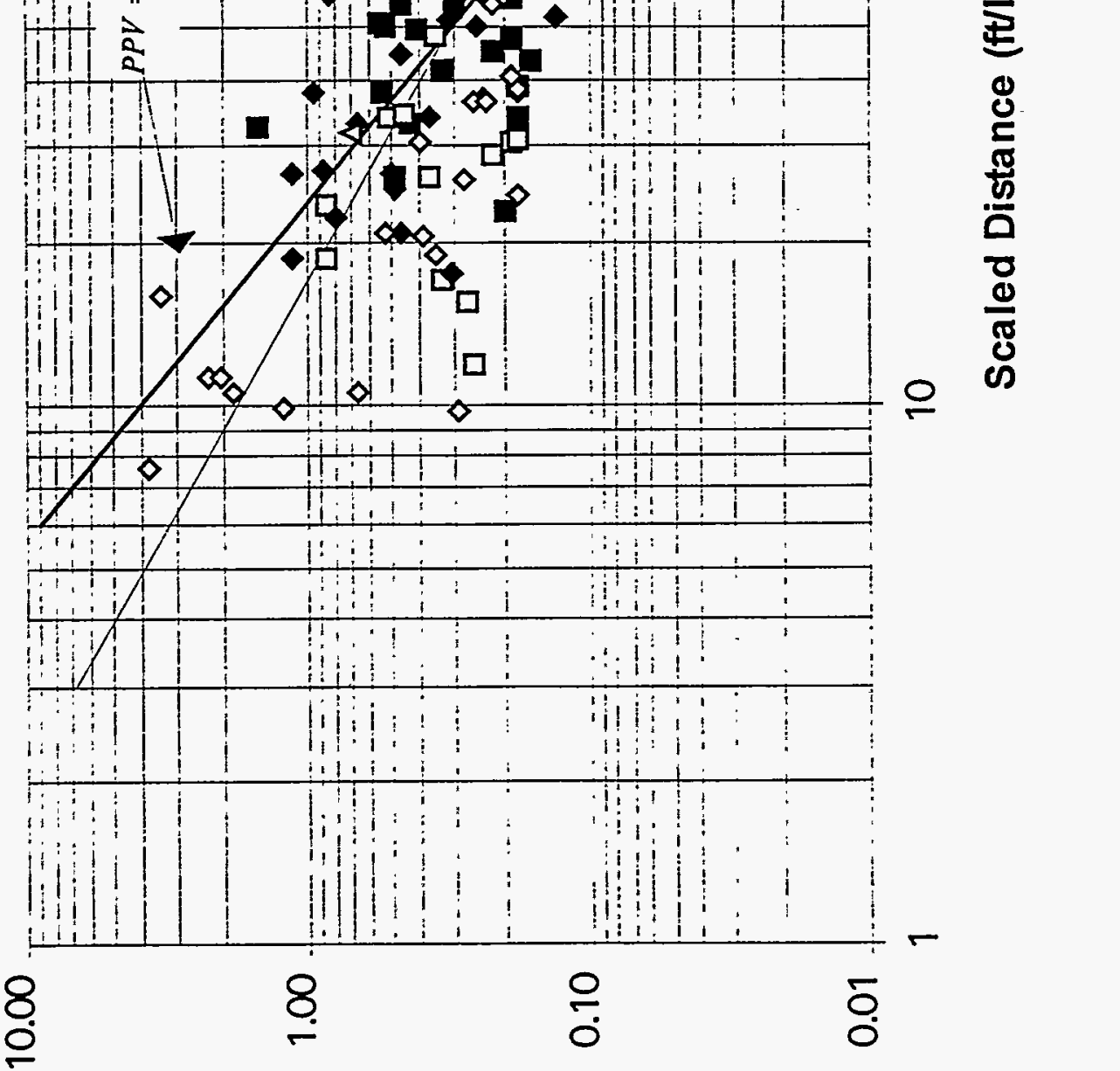

(כәs/u!) ^dd 


\section{NRST Blast Analysis for Top Heading Rounds}

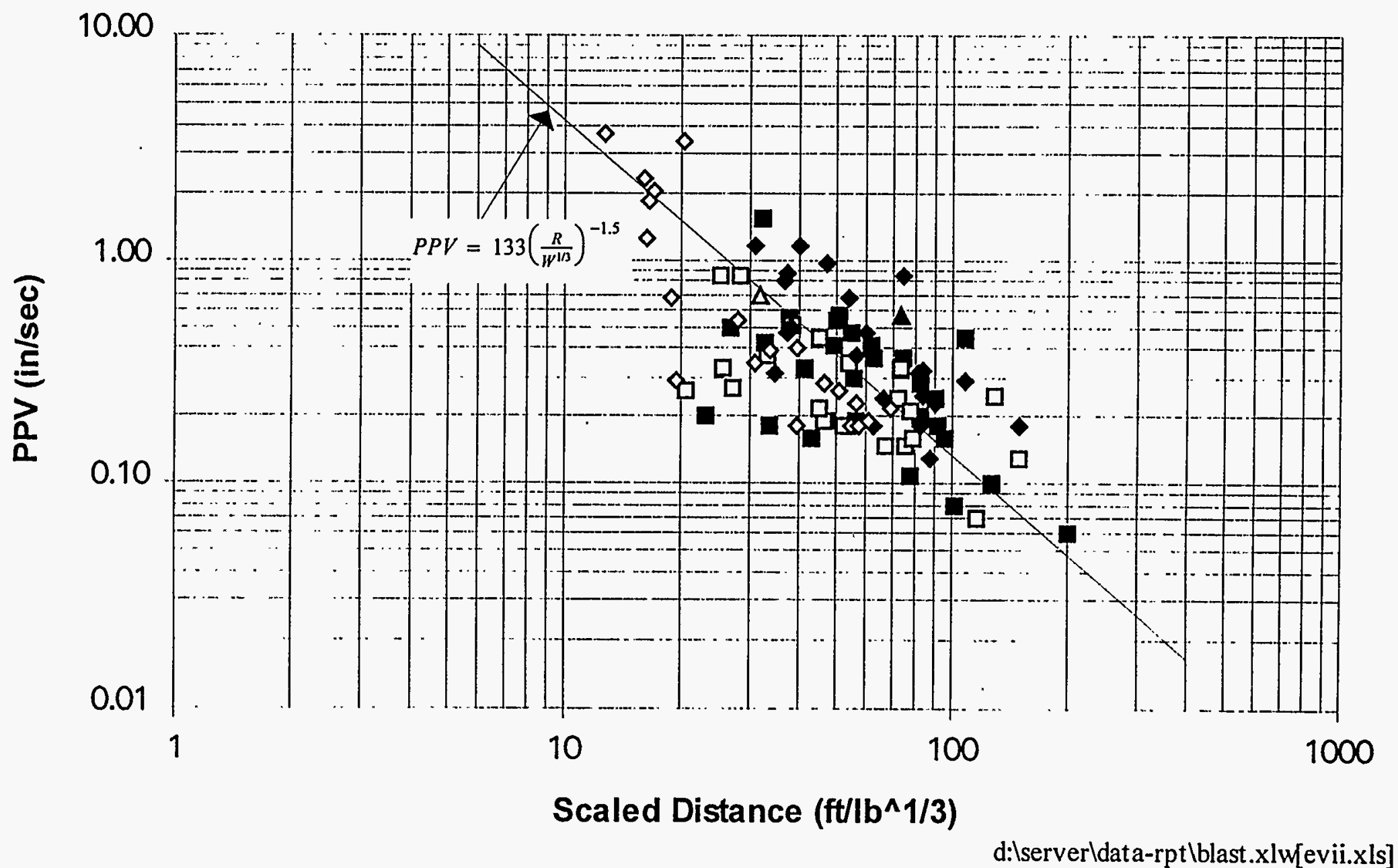

Figure 3-6. PPV versus SD (distance normalized to charge weight to the $1 / 3$ power). 


\subsubsection{Alcove No. 1 Near-Field Blast Monitoring}

Blast damage associated with the excavation of Alcove No. 1 within the NRST was evaluated by monitoring near-field blast vibrations and by making video observations of boreholes in an attempt to determine the extent of damage. A quantitative correlation of PPV with rock damage was then attempted using an approach similar to work done by Holmberg and Persson (1979).

The layout of the monitoring, shown earlier in Figure 2-5, Section 2.3.2.2 was designed to develop data from the first three blast rounds in the Alcove No. 1. Sets of two observation and two instrumentation holes were drilled parallel to the excavation. The observation holes were video logged before blasting and after the fourth round in the Alcove No. 1.

The instrument holes each contained two geophones connected to a four-channel digital oscilloscope. The geophones were oriented to monitor compressional and shear wave vibrations in the horizontal plane. The vertical component was not monitored. During data reduction the vertical component was assumed to be the average of the horizontal components so that a comparison could be made to other triaxial data acquired from the NRST blast monitoring.

The data from three of the first four blasts, TA-1, TA-3 and TA-4, were used for this analysis. Blast TA-2 was not used because it was only a trim round.

To analyze the near-field seismic data, the time of each wavelet peak recorded by the oscilloscope was correlated with a specific delay for each blast. Both single or multiple holes were initiated by a given delay. The asymmetrical design of the blast monitoring layout with respect to the opening resulted in some uncertainty in determining which holes affected the particle velocities measured by the geophones. The burn resulted in a void or disturbed zone in 
Rev 1

the center of the round, thereby disrupting the wave path to the geophones located on the west side of the round. Because of this, blast holes located east of the blast centerline were not included in the charge weight or distance calculations. The perimeter holes used to determine charge weight were limited to those at the west margin of the round up to a height of $3.3 \mathrm{~m}$ (11 ft). The distance from the blast hole to the geophones was determined by using the horizontal distance for delays initiating single holes, however, for multiple holes initiated by the same delay, the horizontal distance to the geometric center of the holes was used.

PPVs were determined from the amplitudes recorded for each wavelet peak associated with a given delay. A vector sum of the particle velocities for each peak was then determined using Equation 3-5:

$$
P P V(\text { total })=\left[P V(\text { comp })^{2}+P V(\text { shear })^{2}+P V(\text { vert })^{2}\right]^{1 / 2}
$$

where one of the two measured components is a peak value and the vertical component of velocity was assumed to be the mean of the two horizontal components. This assumption was based upon examination of the far-field blasting records.

The two scaling relationships presented in Equations 3-2 and 3-3 were used, and the near-field data were combined with the far-field data developed for the NRST top headings (Section 3.3.2) to establish a combined correlation between PPV and scaled distance. The resulting linear regressions are listed in Table 3-4 and shown graphically in Figures 3-7 and 3-8. A listing of the near-field data is presented in Appendix E.

\section{Table 3-4. Combined Near-Field/Far-Field Curve Fit}

\begin{tabular}{lcccc} 
& $\mathbf{5}$ & $\mathbf{P P V}=\mathbf{A}(\mathbf{S D})^{\mathbf{B}}$ \\
\cline { 2 - 5 } & $\mathbf{A}$ & $\mathbf{B}$ & $\mathbf{R}^{2 *}$ & Standard Error \\
\hline $\mathrm{SD}=\mathrm{R} / \mathrm{W}^{1 / 2}$ & 46 & -1.3 & 0.76 & 0.34 \\
$\mathrm{SD}=\mathrm{R} / \mathrm{W}^{1 / 3}$ & 89 & -1.4 & 0.82 & 0.33 \\
\hline${ }^{*} \mathrm{R}^{2}-$ Correlation coefficient $^{2}$ & & & \\
\hline \hline
\end{tabular}


Rev 1

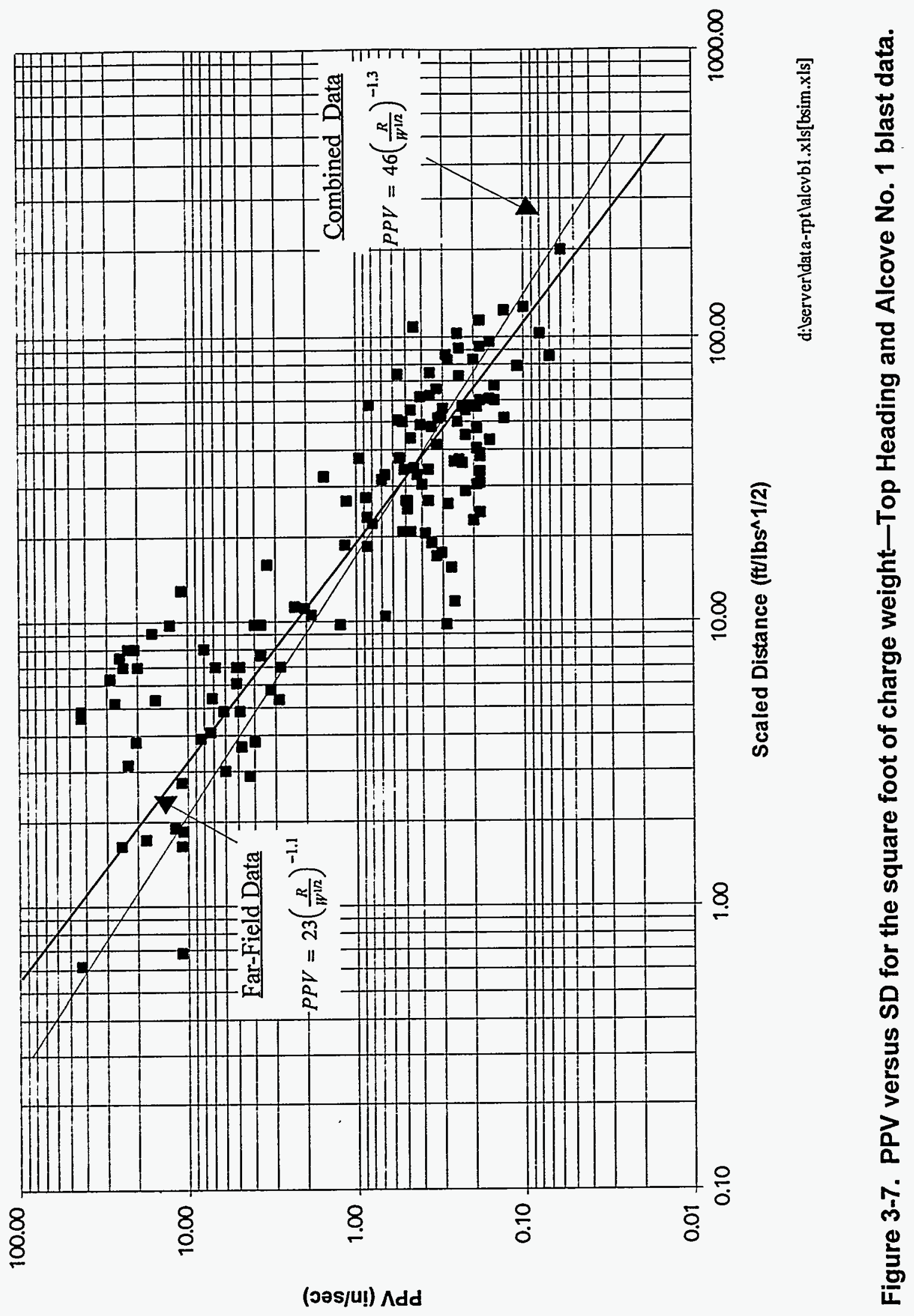


SAND95-1675

$08 / 25 / 95$

Rev 1

8

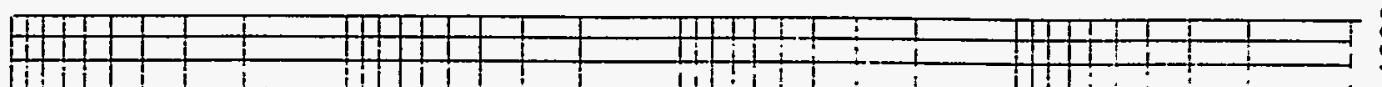

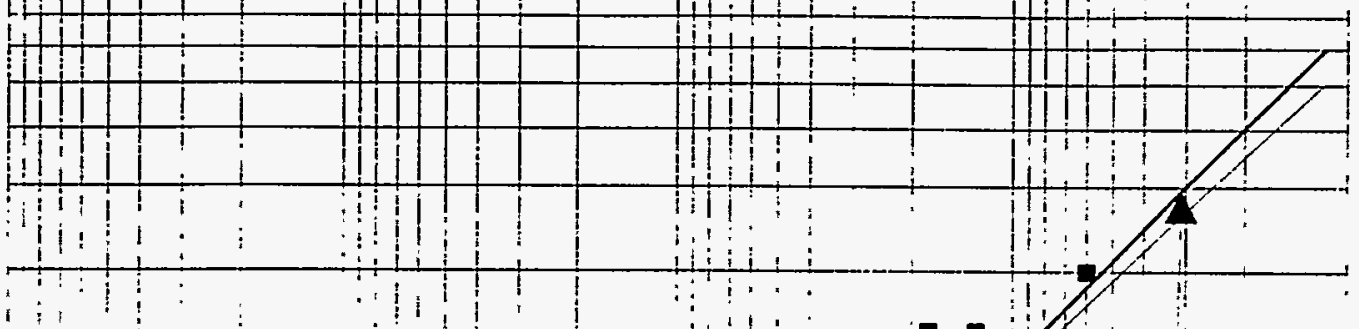

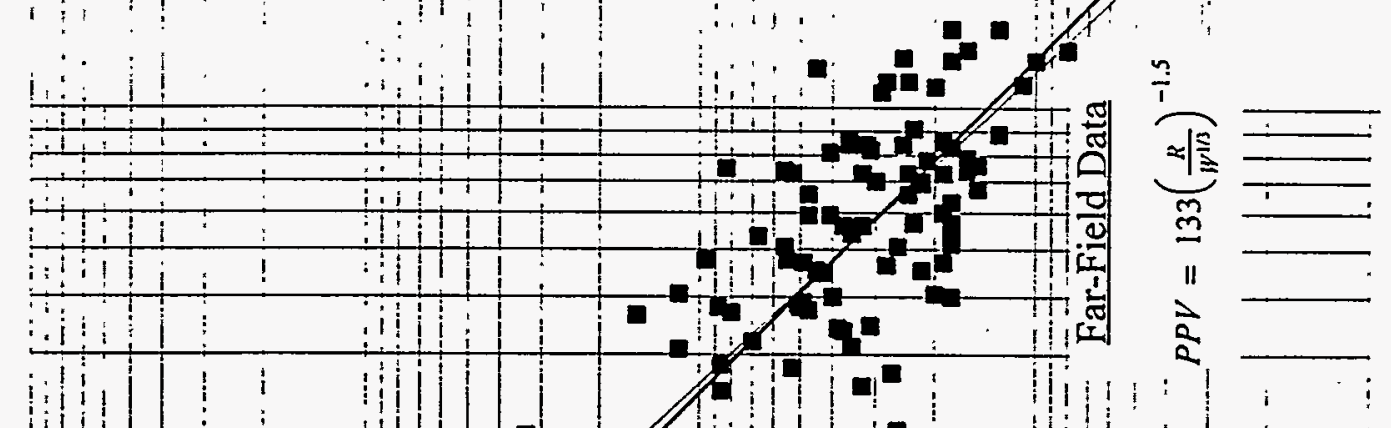

8

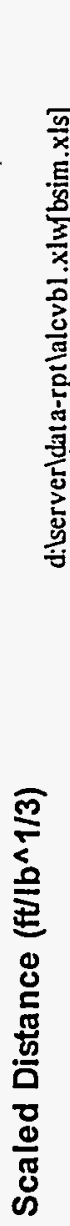

(

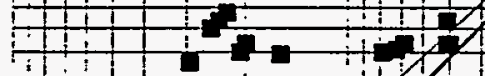

.

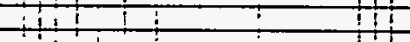

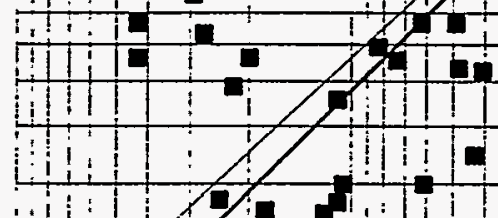
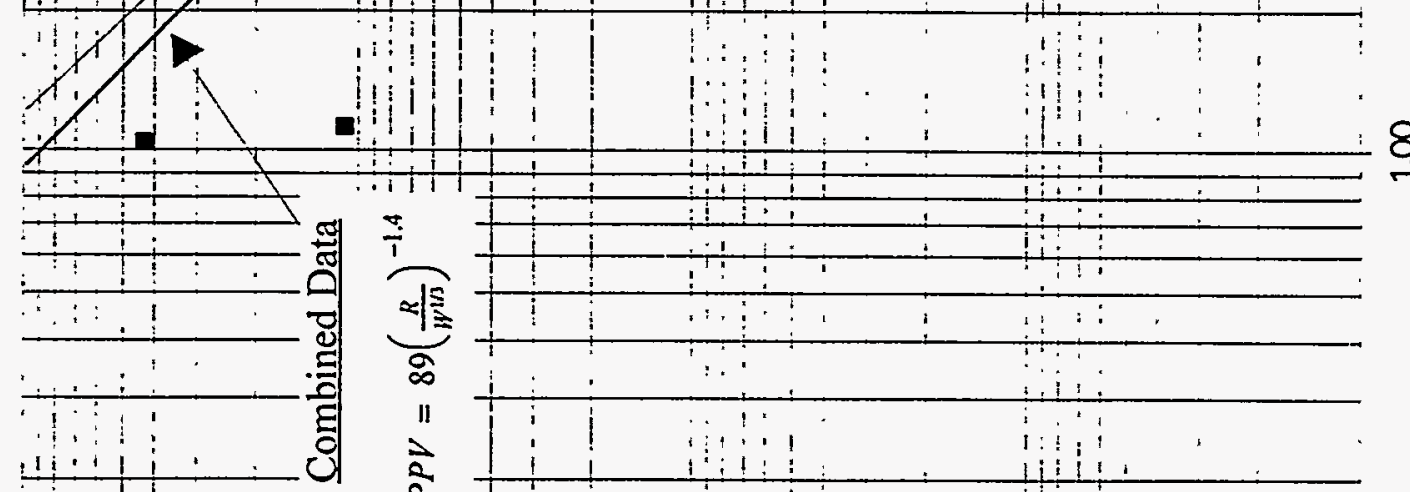

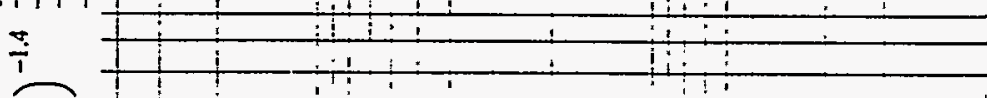

평

Af
21

क

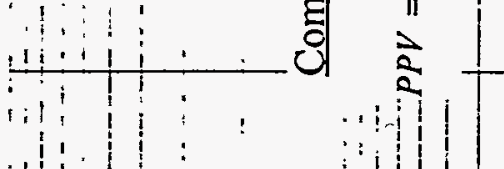

8

8

inil

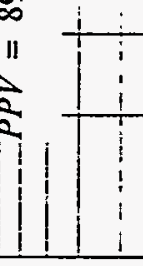
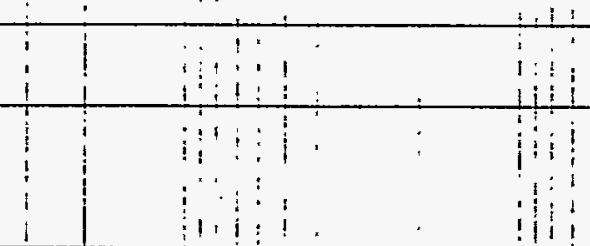

1: : $1:$

8

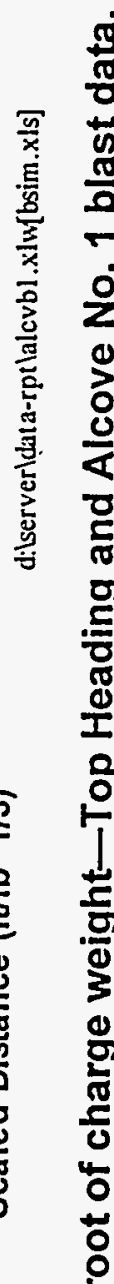

吕

$\stackrel{\Xi}{E}$

는

क

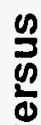

$\$$

$\frac{1}{2}$

$\stackrel{\infty}{\infty}$

(oos/u!) ^dd 
Rev 1

The curve fits of combined near-field and far-field blast monitoring data are compared to curve fits of the far-field data in the two figures. The curves are quite similar and suggest that extension of the scaling criteria to the near-field is appropriate in the frequency range monitored.

\subsubsection{Evaluation of Blast Damage by Borehole Video Logs}

The observation boreholes were video borescoped before blasting and after blast round TA-4. The intention of the borescope logging was to determine the difference in the number of fractures before and after blasting as done by Holmberg and Persson (1979). However, grout from nearby rockbolts had penetrated the observation holes between observations. Qualitative observations made during the post-blast video logging indicated that some of the grout had fractured in the holes nearest the Alcove No. 1, $0.91 \mathrm{~m}(3 \mathrm{ft})$ from the blast boundary, but not in

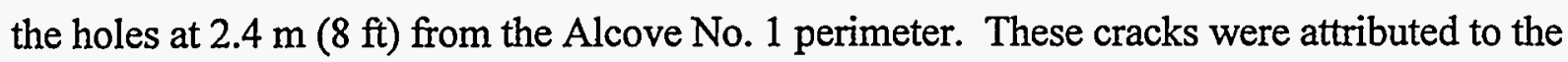
blasting and were used in place of a fracture counting approach.

Figure 3-9 shows the velocity histories for the holes at $0.91 \mathrm{~m}(3 \mathrm{ft})$ and $2.4 \mathrm{~m}(8 \mathrm{ft})$ from the Alcove No. 1 wall and compares them to the range of PPV reported to cause rock damage by Holmberg and Persson (1979). A maximum PPV of $1100 \mathrm{~mm} / \mathrm{sec}(43 \mathrm{in} / \mathrm{sec})$ was recorded for the hole at $0.91 \mathrm{~m}(3 \mathrm{ft})$ and $650 \mathrm{~mm} / \mathrm{sec}(25 \mathrm{in} / \mathrm{sec})$ for the hole at $2.4 \mathrm{~m}(8 \mathrm{ft})$. Holmberg and Persson indicate that blast damage begins in the range of $700-1000 \mathrm{~mm} / \mathrm{sec}(28-39 \mathrm{in} / \mathrm{sec})$. The results of the borehole inspection are consistent with this range.

\subsection{Instrumentation Results}

The results of monitoring the instrumentation installed in the NRST are presented in this section for the time period between installation and the end of June 1995. The data are presented 
SAND95-1675

Rev 1

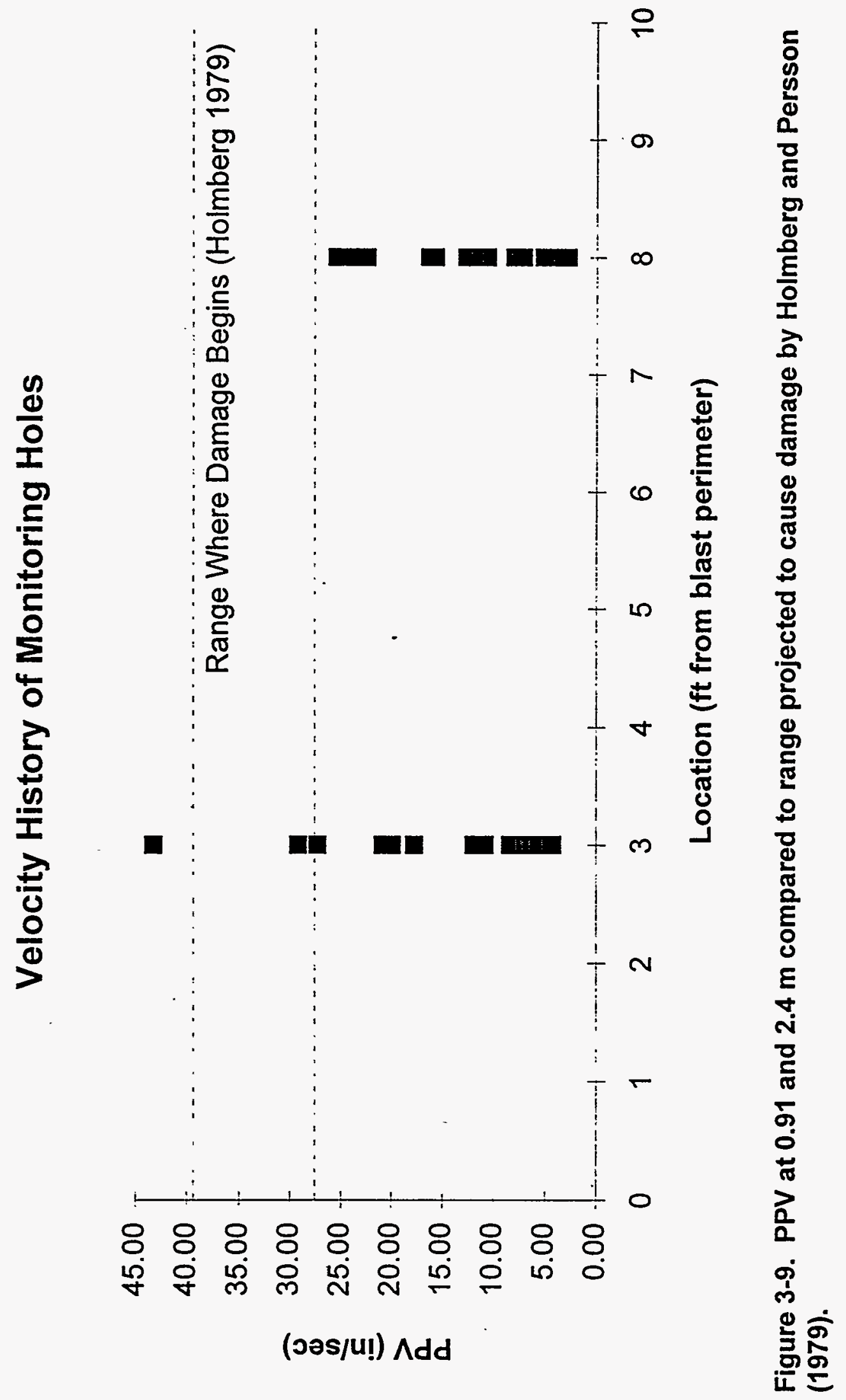


Rev 1

by increasing NRST stations (distance) beginning with the portal highwall or face. This section also presents the results of monitoring at station $0+56.3 \mathrm{~m}$ as the TBM excavated past the installed BHPC instruments.

\subsubsection{NRST Main Tunnel Sections}

3.4.1.1 Station $0+00 \mathrm{~m}$-Portal Face (Highwall). Data from the three rockbolt load cells installed at the portal face are presented in Figure 3-10. The rockbolts were installed untensioned and fully grouted along their lengths of $6.1 \mathrm{~m}$ (2612 North, 2615 South) and $3 \mathrm{~m}$ (2614 Center), respectively. The load cells were attached after grout cure and initial loads were set between $9.79-21.13 \mathrm{kN}(2200-4750 \mathrm{lbs})$. The response of all three cells was characterized by load bleed-off until July 31, 1993, when excavation of the NRST bench was begun. A small increase in load, possibly associated with bench excavation, was observed in 2612 North. This was immediately followed by continued load bleed-off which stabilized around January 1994. Since that time, 2612 North and 2614 South have exhibited long-period oscillations with the load increasing and decreasing within a bracket of roughly $6.67 \mathrm{kN}(1500 \mathrm{lbs})$.

The rockbolts were manufactured from high-strength steel with specified yield loads of $159.9 \mathrm{kN}(36,000 \mathrm{lbs})$ and ultimate load of $239.9 \mathrm{kN}(54,000 \mathrm{lbs})$ for the \#7 bolt. Yield load for the \#9 bolts was $267 \mathrm{kN}(60,000 \mathrm{lbs})$ and ultimate load was $356 \mathrm{kN}(80,000 \mathrm{lbs})$. The maximum load observed at installation was approximately $21.1 \mathrm{kN}(4,750 \mathrm{lbs})$ or $8 \%$ of yield load. Load changes observed at the head of the bolts since installation indicate all stresses at the head of the bolt are currently less than the yield stress. 
SAND95-1675

Rev 1

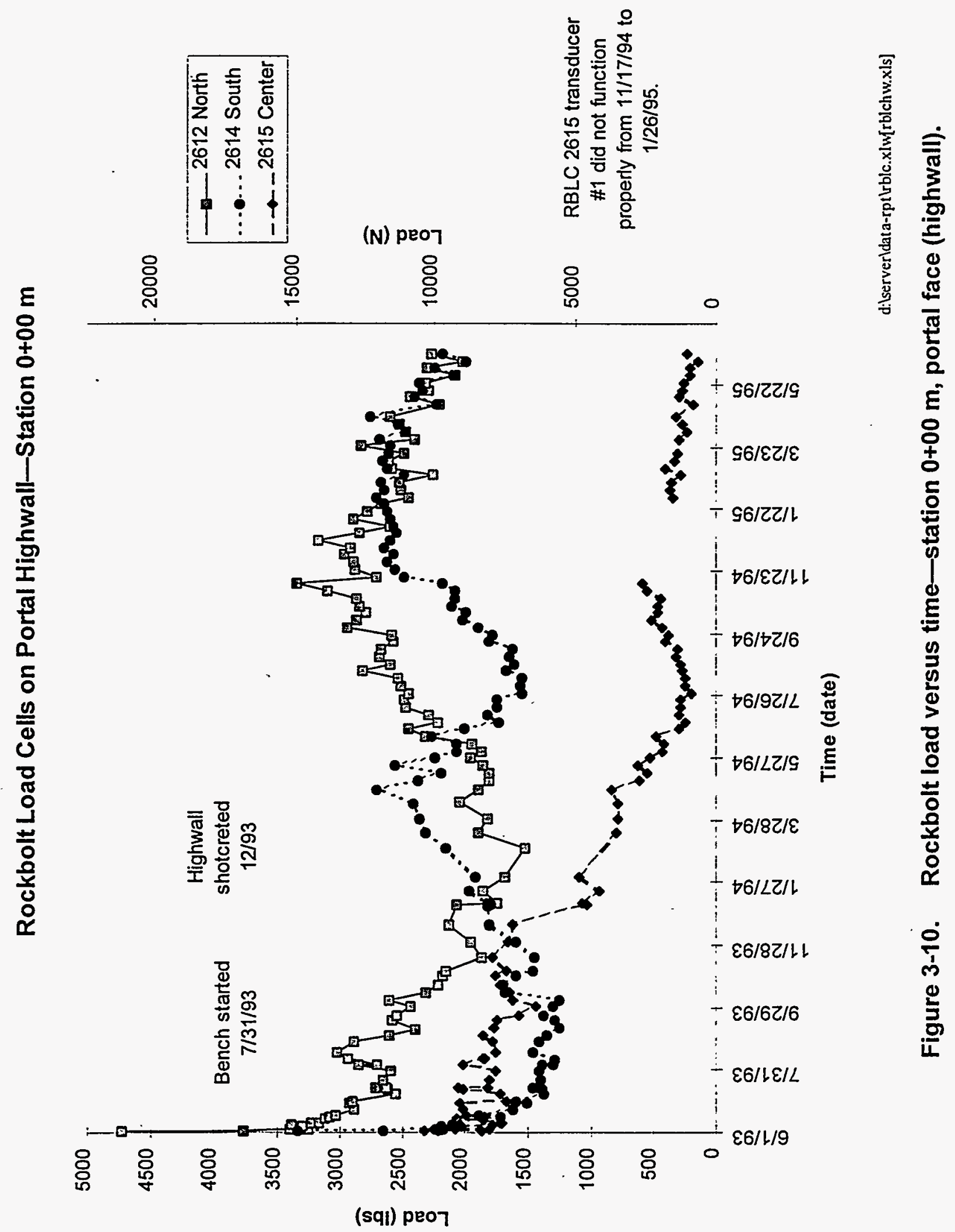




\subsubsection{Portal Lattice Girder Convergence-Stations $0+4.6 \mathrm{~m}$ and $0+9.1 \mathrm{~m}$.}

Lattice girder convergence history is presented in Figures 3-11 and 3-12 for girders \#4 and \#7, respectively. Convergence at both stations exhibited similar characteristics and magnitudes. The change in the horizontal chords (SLL-SLR) indicated generally increasing closure with time from installation to August 1994, then stabilizing beyond this time. The horizontal chords were established at installation before excavation of the bench. Closure stabilized immediately after installation, but then began to increase with excavation of the bench in August and September 1993. Closure of the horizontal chords exhibited another period of stability after removal of the bench was completed, then another sharp increase to the currently indicated plateau.

The floor pins were reestablished after removal of the bench and embedment of the lattice girders in shotcrete. Roof-to-floor closure oscillated with no real trend until roughly December 1994, at which point both stations indicated an increase in the roof-to-floor chord lengths. This period of time corresponds to movement of the TBM into the tunnel and sumping in of the cutter head. These construction activities may have resulted in settlement displacements in the floor that account for the apparent expansion in the vertical direction. The trend of the latest three measurements at lattice girder \#4 has been increased roof-to-floor closure at rates between $0.009 \mathrm{~mm} /$ day $(0.00035 \mathrm{in} /$ day $)$ and $0.0011 \mathrm{~mm} /$ day $(0.00043 \mathrm{in} /$ day $)$; similar values occur for lattice girder \#7.

3.4.1.3 Tunnel Convergence-Station $0+10.7 \mathrm{~m}$. Convergence data for station $0+10.7 \mathrm{~m}$ in the main tunnel is presented in Figure 3-13. This station is just beyond the lattice girders in rock supported by shotcrete and rockbolts. The pattern of convergence is similar to both lattice girder stations. The horizontal chord indicates steady closure up to $4.4 \mathrm{~mm}$ 


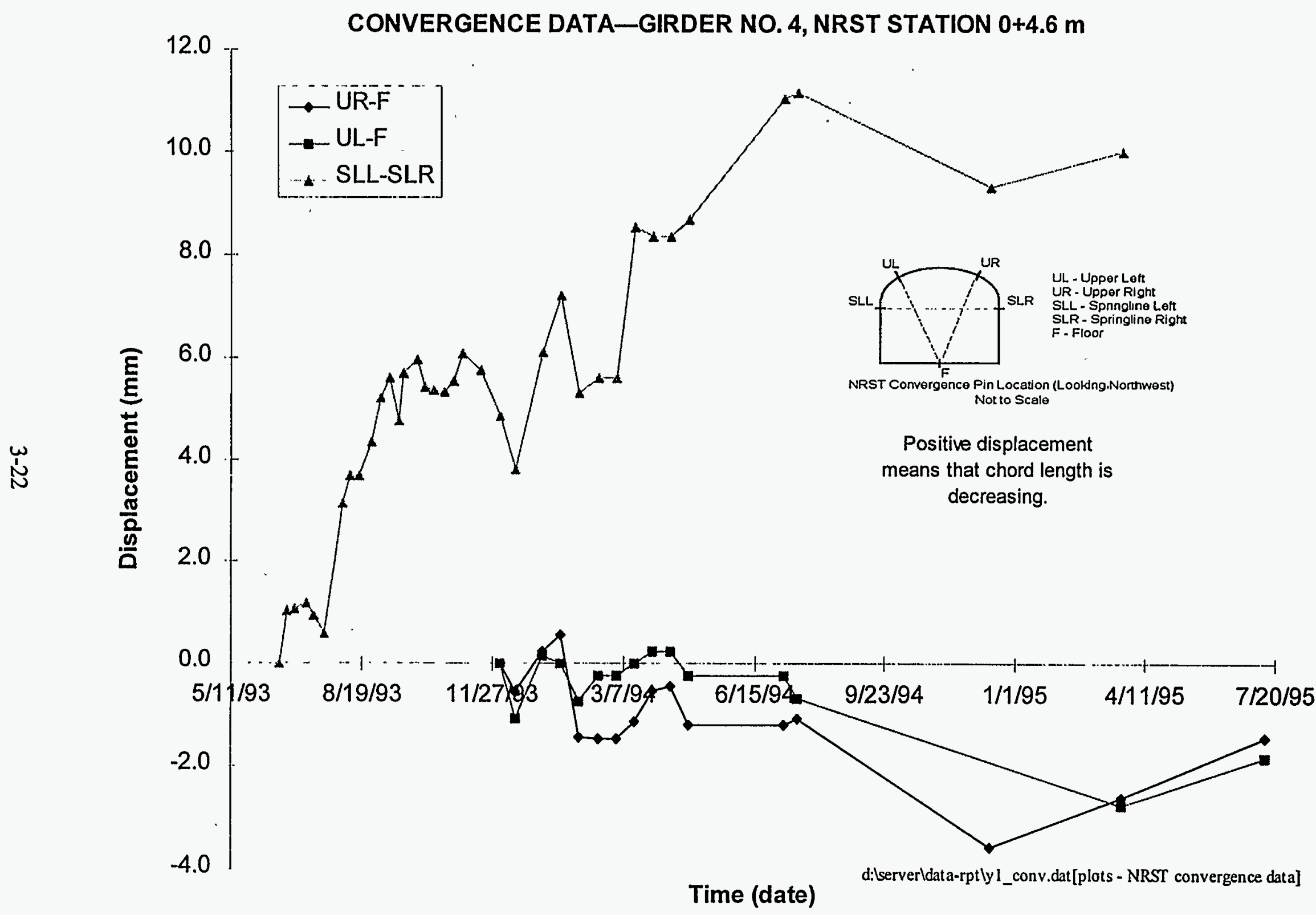

Time (date)

Figure 3-11. Convergence versus time for lattice girder No. 4 at NRST station $0+4.6 \mathrm{~m}$. 
CONVERGENCE DATA-GIRDER NO. 7, NRST STATION 0+9.1 m

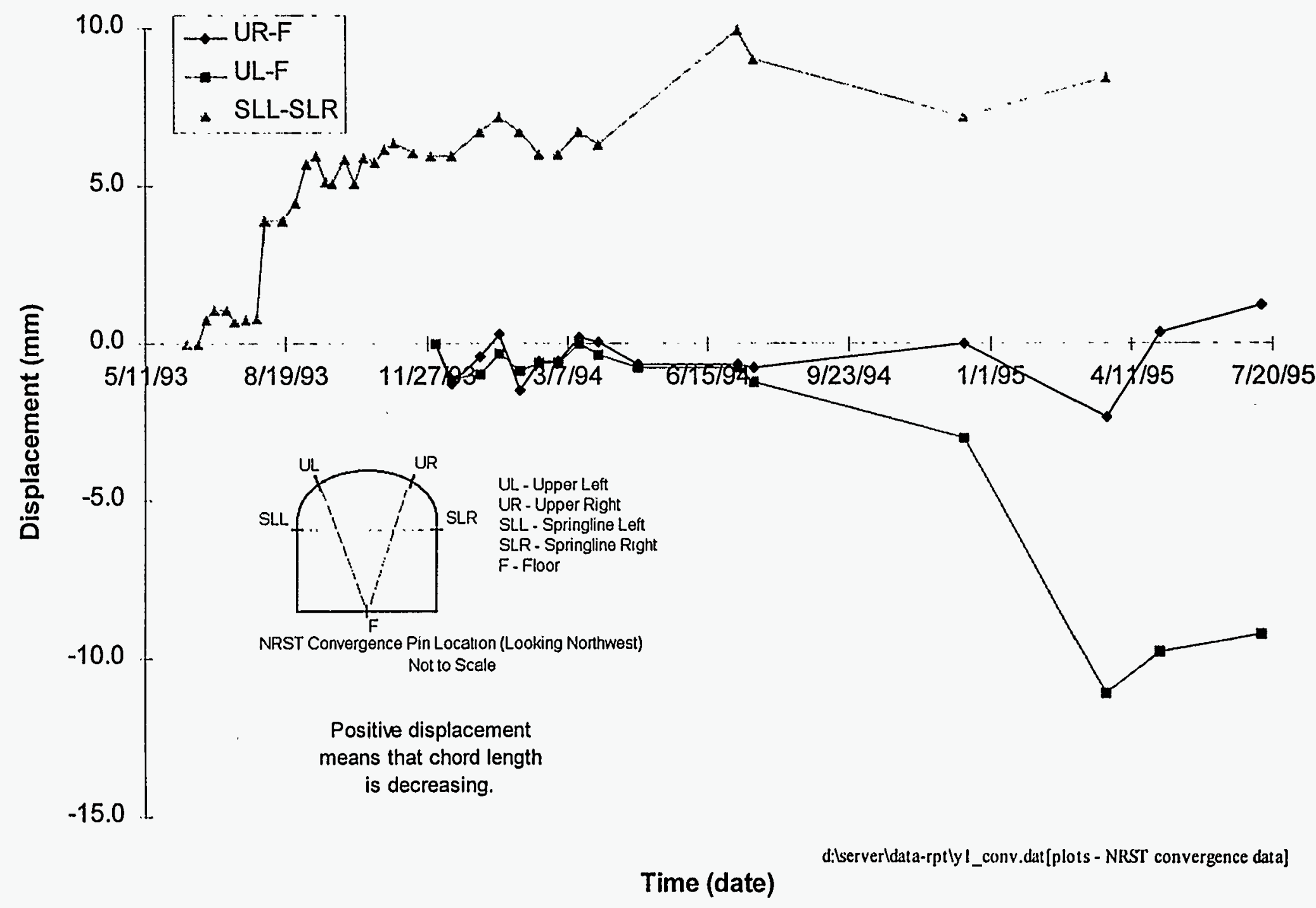

Figure 3-12. Convergence versus time for lattice girder No. 7 at NRST station 0+9.1 m. 


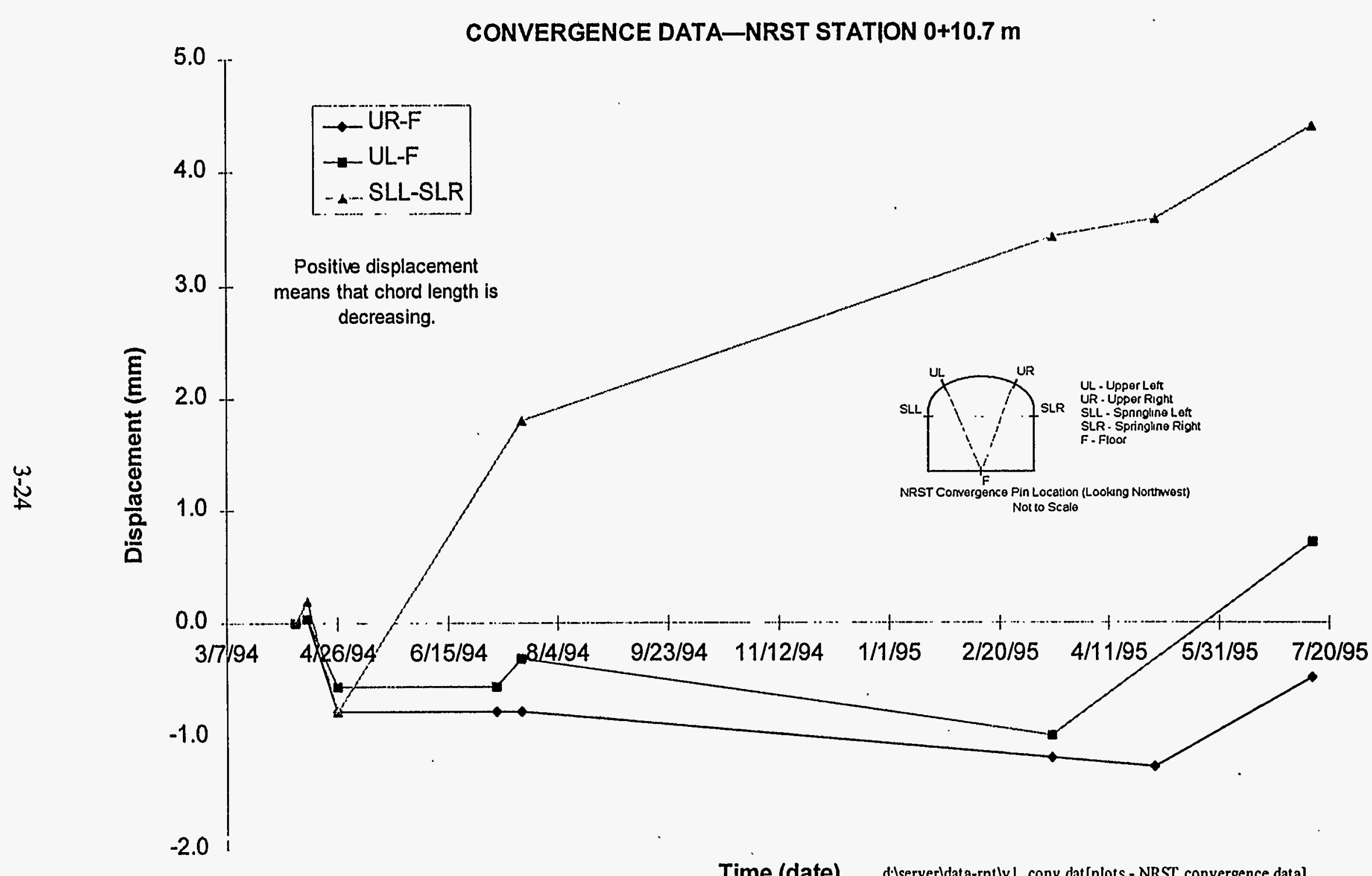

Time (date) dilserverldata-rptly!_conv.dat[plots - NRST convergence data]

Figure 3-13. Convergence versus time-NRST station 0+10.7 m. 
Rev 1

( $0.173 \mathrm{in})$ and a closure rate of $0.0114 \mathrm{~mm} /$ day $(0.0004 \mathrm{in} /$ day $)$. Roof-to-floor chords indicated very small expansion, $1.3 \mathrm{~mm}$ maximum, then a change in direction to tunnel closure in the most recent reading with closure rates of 0.011 (0.0004 in/day) and $0.014 \mathrm{~mm} /$ day $(0.0006 \mathrm{in} /$ day $)$.

\subsubsection{Convergence and Rockbolt Load-NRST Station 0+16.8 m.}

Convergence data for station 0+16.8 $\mathrm{m}$ are presented in Figure 3-14 and indicate behavior very similar to the lattice girders and station $0+10.7 \mathrm{~m}$. All chords were established in November 1993 after installation of the final ground support. The horizontal chord indicates a trend of continued closure with one period where closure rates dropped to zero. The current maximum horizontal closure had reached $7.1 \mathrm{~mm}$ ( $0.279 \mathrm{in})$ by July 1995 with the closure rate equal to $0.009 \mathrm{~mm} /$ day $(0.0004 \mathrm{in} / \mathrm{day})$. The roof-to-floor chords showed very small expansions up to the time that the TBM was launched. In late December 1994, the roof-to-floor chords indicated a further expansion (up to a maximum $-3.6 \mathrm{~mm}(-0.14$ in) that may be associated with settlement of the floor due to the TBM loading. The roof-to-floor chords have indicated closure since January 1995 with a maximum change of $2.8 \mathrm{~mm}(0.111 \mathrm{in})$ and closure rates of $0.020 \mathrm{~mm} /$ day (0.0008 in/day) and $0.010 \mathrm{~mm} /$ day (0.0004 in/day) for UL-F and UR-F, respectively.

Rockbolt loads for station $0+16.8 \mathrm{~m}$ are presented in Figure 3-15. The load history of all three instruments indicate initial load bleed-off followed by very stable load-time behavior. All bolts were untensioned, fully grouted, and pull tested to levels at least $111.2 \mathrm{kN}(25,000 \mathrm{lbs})$ prior to installation of the load cells. The peak bolt load generated by torquing the nut attaching the load cell at the bolt head was $31.6 \mathrm{kN}(7100 \mathrm{lbs})$ or $11.8 \%$ of yield strength.

\subsubsection{Convergence and Rockbolt Load-NRST Station 0+27.4 m.}

Convergence data for station $0+27.4 \mathrm{~m}$ are presented graphically in Figure 3-16. There is considerable scatter in the data up to July 1994; however, the general character of the curves are 


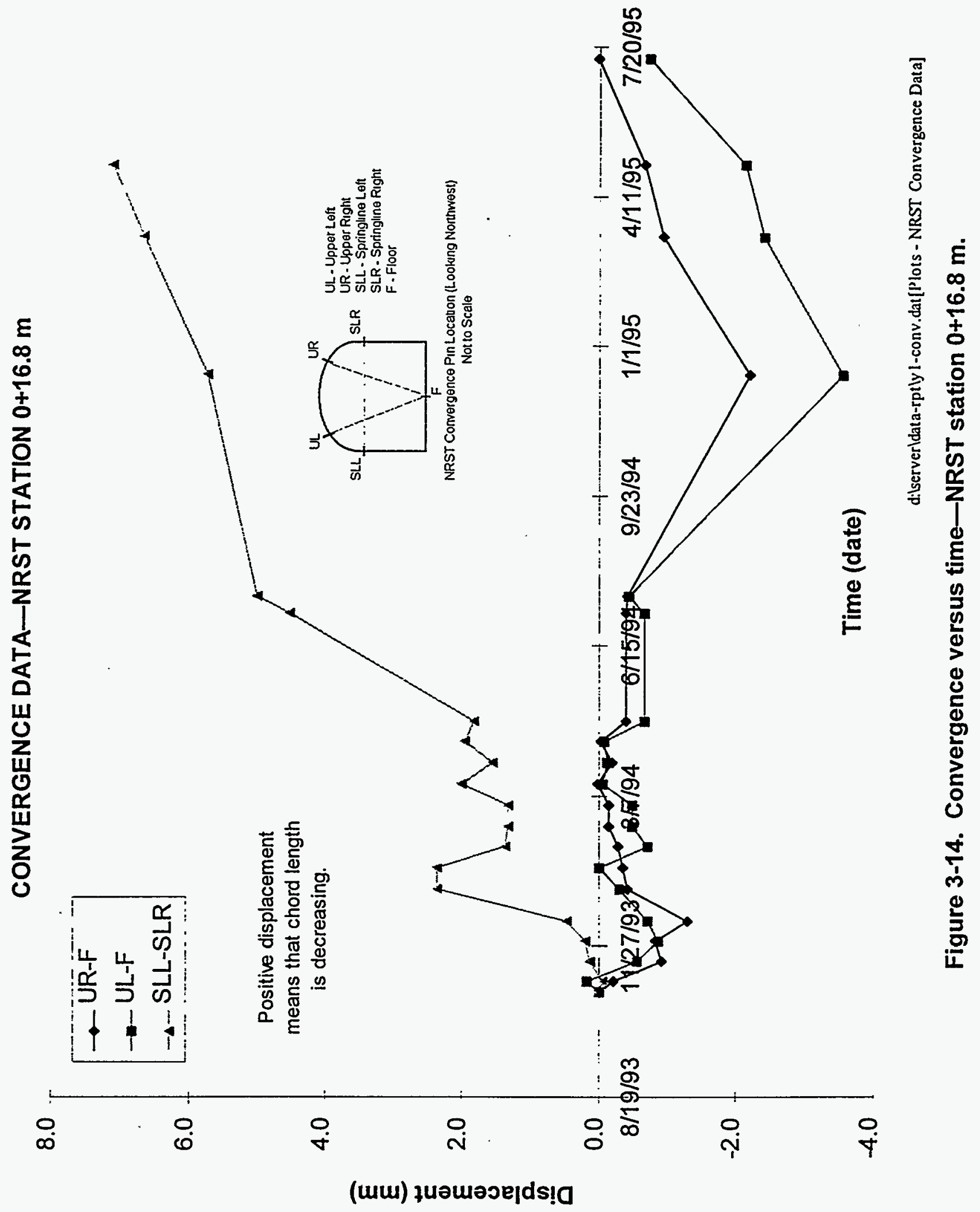


Rev 1

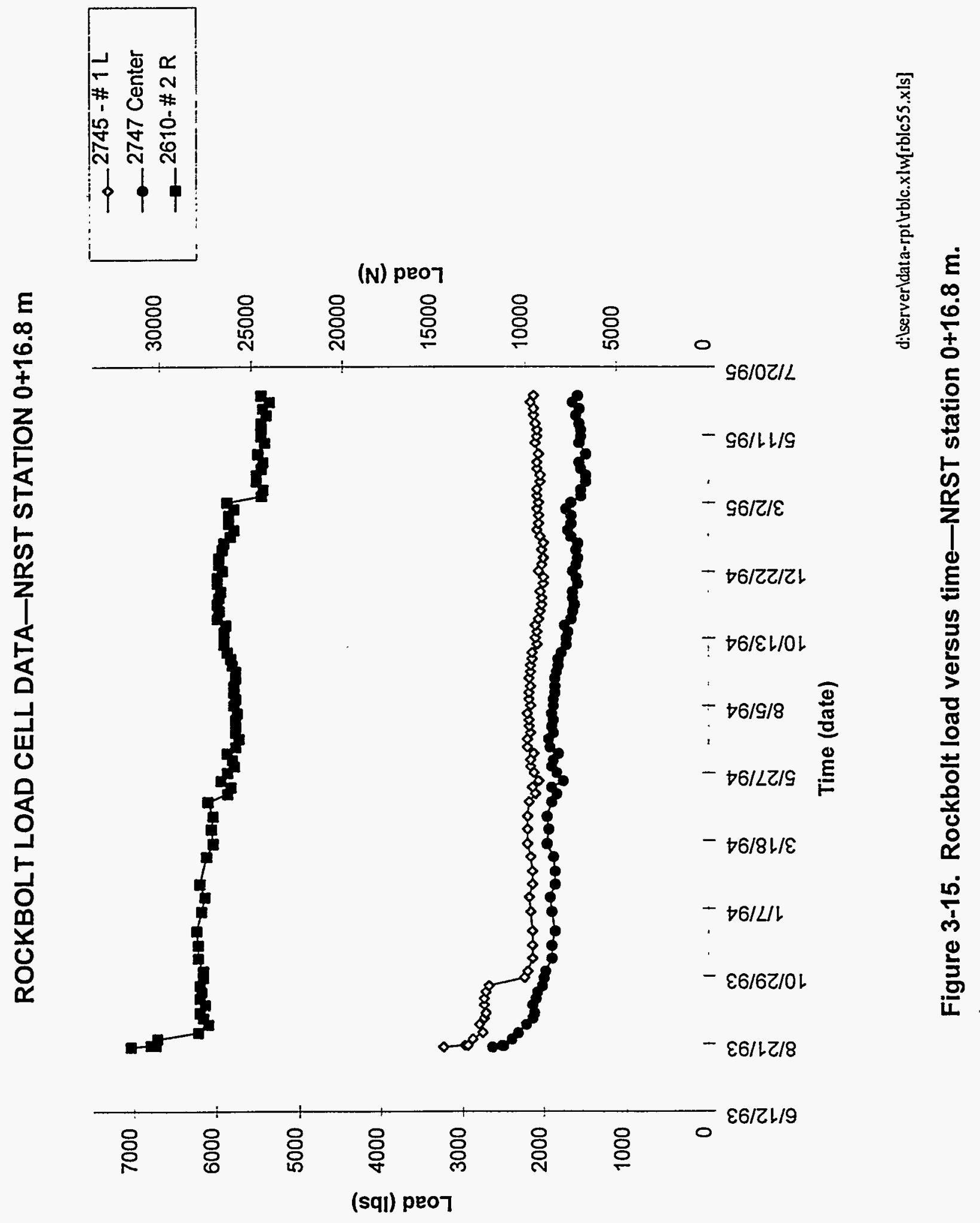




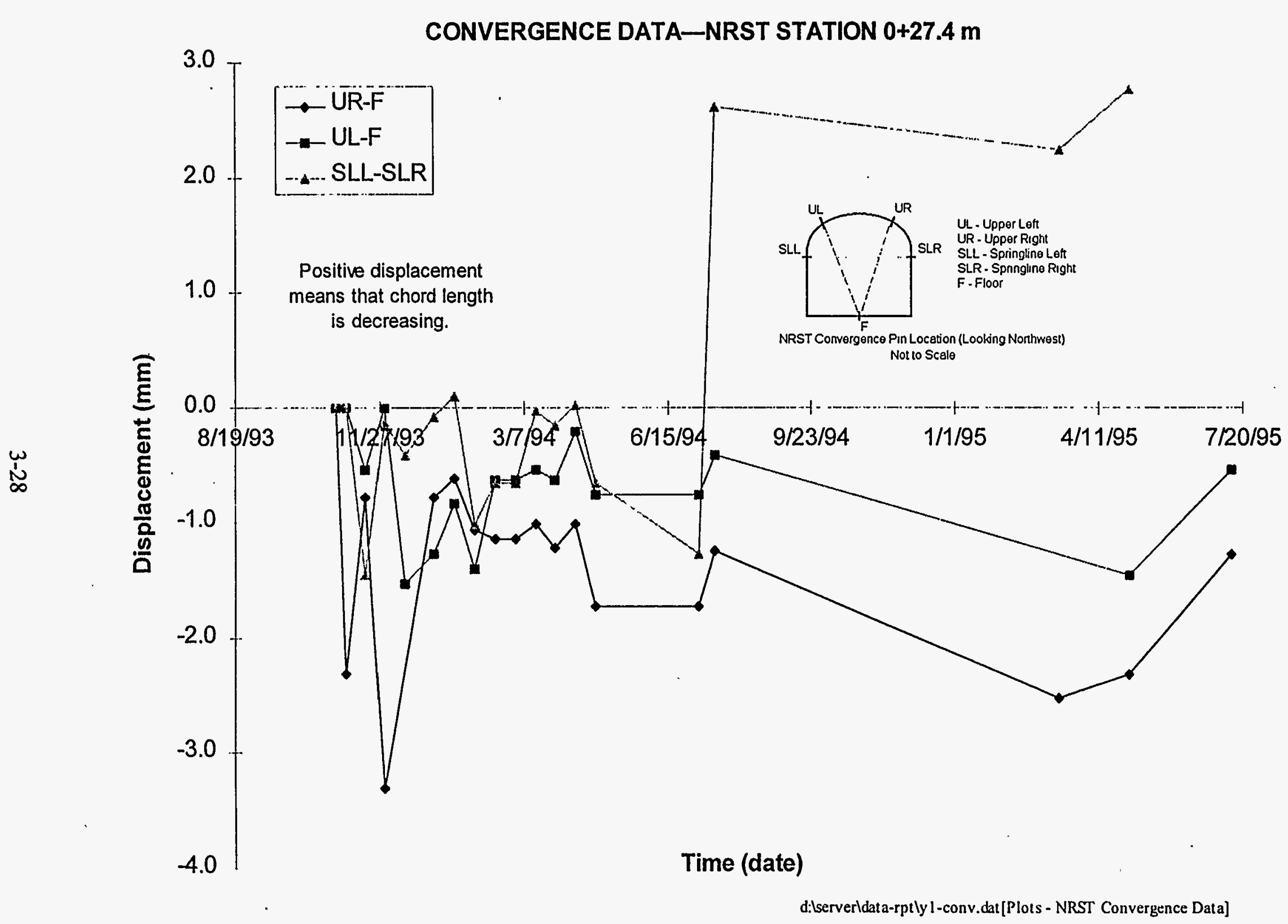

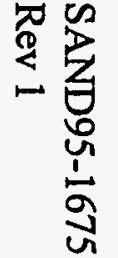

Convergence Data)

Figure 3-16. Convergence versus time-NRST station 0+27.4 m. 
Rev 1

similar to trends at the lattice girders and at stations $0+10.7 \mathrm{~m}$ and $0+16.8 \mathrm{~m}$. The horizontal chord indicates a maximum closure of $2.8 \mathrm{~m}(0.109 \mathrm{in})$. Peak rates of closure were $0.045 \mathrm{~mm} /$ day (0.0018 in/day); however, closure rates have stabilized since mid-June 1994. The roof-to-floor chords show considerable scatter and general expansion up to a peak value of $-2.5 \mathrm{~m}(-0.1 \mathrm{in})$. This trend changes to closure after January 1995 with rates up to $0.015 \mathrm{~mm} /$ day (0.0006 in/day) in July 1995 .

Rockbolt load at the head of the grouted bolts is presented in Figure 3-17. Installation loads generated by torquing the nut against the load cell ranged between $27.1 \mathrm{kN}(6100 \mathrm{lbs})$ and $33.6 \mathrm{kN}(7550 \mathrm{lbs})$. After initial load bleed-off, the bolts have been generally stable or have shown slight reductions in load. Peak load at the bolt head is less than $11.2 \%$ of the yield load.

\subsubsection{Convergence and Rockbolt Load-NRST Station $0+33.5 \mathrm{~m}$.}

Convergence data for station $0+33.5 \mathrm{~m}$ is presented graphically in Figure $3-18$. The convergence history is similar to stations $0+4.6 \mathrm{~m}, 0+9.1 \mathrm{~m}, 0+10.7 \mathrm{~m}, 0+16.8 \mathrm{~m}$, and $0+27.4 \mathrm{~m}$ with the exception that the roof-to-floor chords indicate continued expansion. Peak closure on the horizontal chord had reached $3.7 \mathrm{~mm}(0.146 \mathrm{in})$, but closure rates were near zero at the last reading in mid-March 1995. Roof-to-floor chords have reached a maximum expansive deformation of $3.4 \mathrm{~mm}(-0.133 \mathrm{in})$.

Rockbolt load cell data are presented graphically in Figure 3-19. Installation loads varied from 29.3 to $41.4 \mathrm{kN}$ (6580 to $9320 \mathrm{lbs}$ ). Load histories have been generally stable with slightly increasing trends in the \#3R and \#1R locations. Peak installation loads were less than $15.5 \%$ of the yield load at the bolt head. 
Rev 1

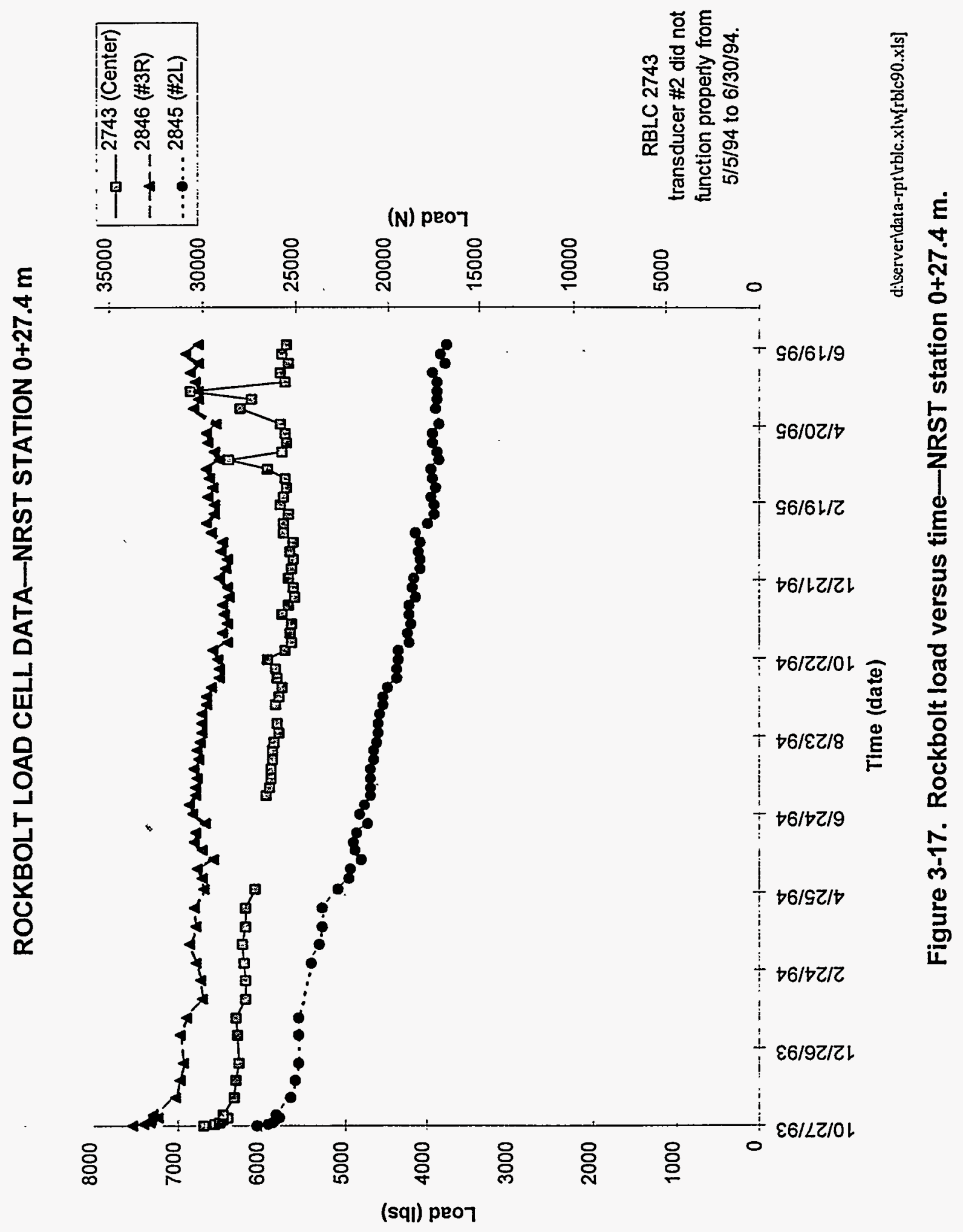




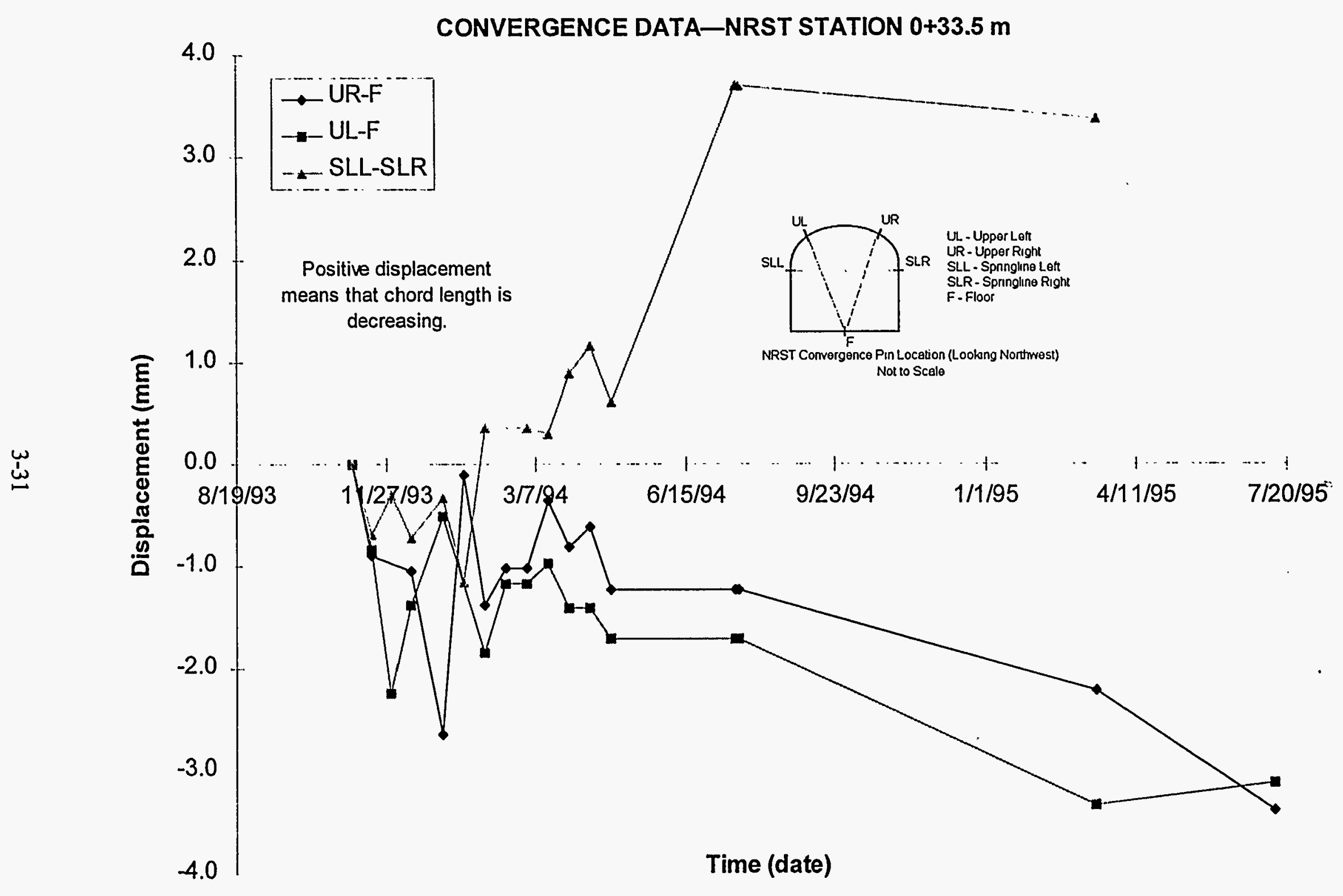

d:Iserverldata-rptly 1-conv.dat [Plots - NRST Convergence Data]

Figure 3-18. Convergence versus time-NRST station $0+33.5 \mathrm{~m}$. 
ROCKBOLT LOAD CELL DATA-NRST STATION 0+33.5 m

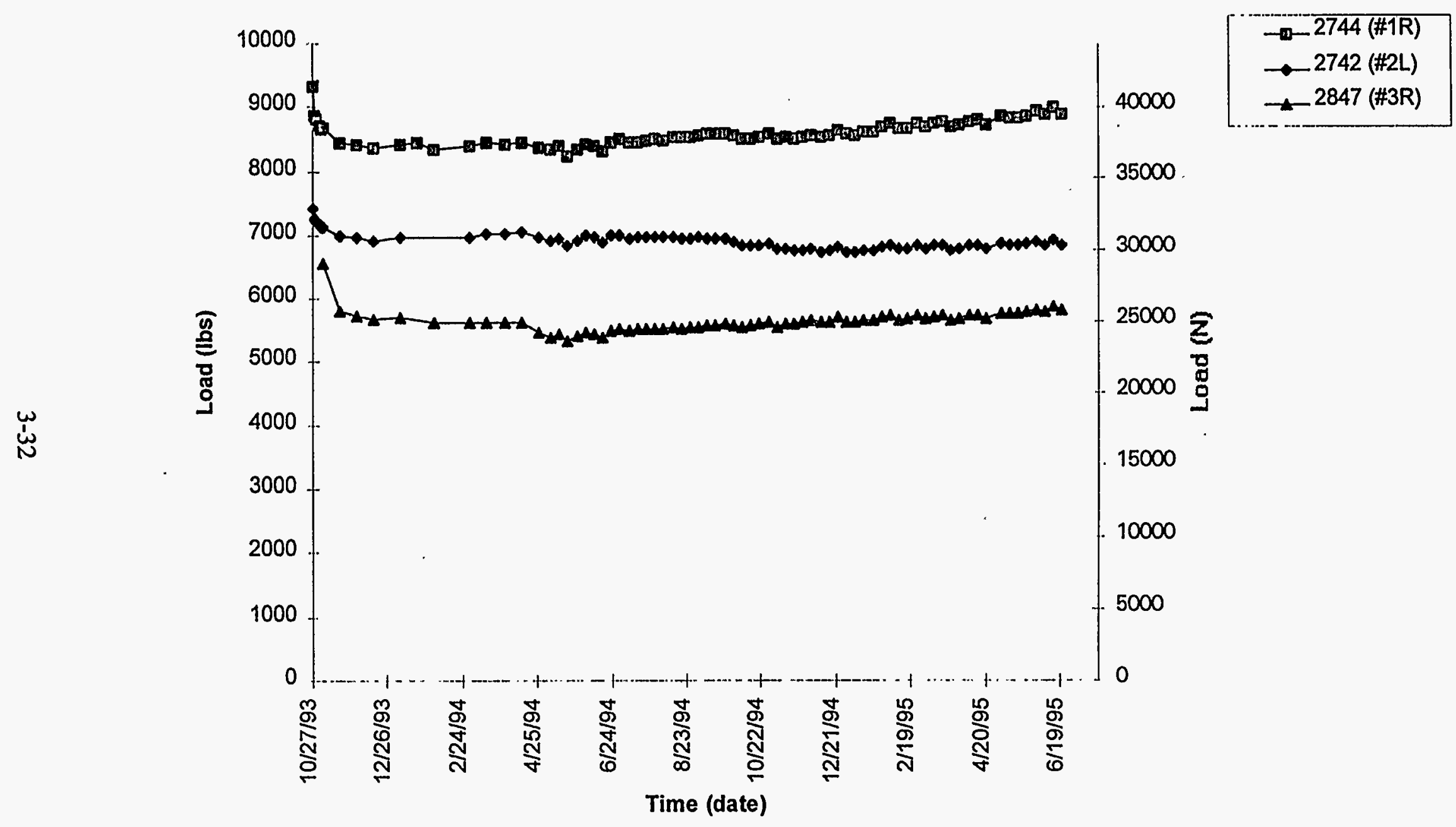

Figure 3-19. Rockbolt load versus time-NRST station $0+33.5 \mathrm{~m}$. 
Rev 1

\subsubsection{Displacement and Rockbolt Load-NRST Station 0+42.7 m.}

Convergence data for station $0+42.7 \mathrm{~m}$ is presented in Figure 3-20. The arrangement at 0+42.7 $\mathrm{m}$ was slightly different because of the intersection with Alcove No. 1. Roof-to-floor chords have the same arrangement, however, two horizontal chords were measured to convergence pins on the west and east sides of the alcove entrance. The pattern of convergence is similar to the previous stations, with the horizontal chords (SLL-A1L, SLL-A1R) showing closure and reaching an apparent plateau with increasing time. Maximum closure had reached $8.4 \mathrm{~mm}(0.332 \mathrm{in})$ before reversing direction. Closure rates at March 1995 were a maximum of $0.025 \mathrm{~mm} /$ day $(0.001 \mathrm{~mm} /$ day). Roof-to-floor chords showed general stable behavior until the July 1995 reading with indicated closure rates of $0.024 \mathrm{~mm} /$ day $(0.0009 \mathrm{in} /$ day $)$ and $-0.038 \mathrm{~mm} /$ day $(-0.0015 \mathrm{in} /$ day) for UL-F and UR-F, respectively.

Data from the five-point MPBX installed vertically at station $0+42.7 \mathrm{~m}$ is presented in Figure 3-21. The initial pattern of displacement change was typical, with the deepest anchor showing the greatest change and the shallowest anchor showing the least change. The displacements indicated closure, or movement, of the rock surface into the excavation. All gages abruptly reversed direction around February 15,1994 , and the pattern of change became irregular in all but the anchor at $1.7 \mathrm{~m}$ which showed a consistent pattern of closure at a very low rate. The maximum change as of June 1995 was $0.60 \mathrm{~mm}(0.024 \mathrm{in})$ recorded at the shallowest anchor. Seven-day interval displacement rates are shown graphically in Figure 3-22, and indicate an oscillatory pattern around zero with relatively low rates of change $(0.004 \mathrm{~mm} /$ day, $0.0002 \mathrm{in} /$ day) in June 1995.

Rockbolt load as a function of time is shown graphically in Figure 3-23. Following the initial load bleed-off, the bolts exhibit different behaviors; however, the amount of load change is 


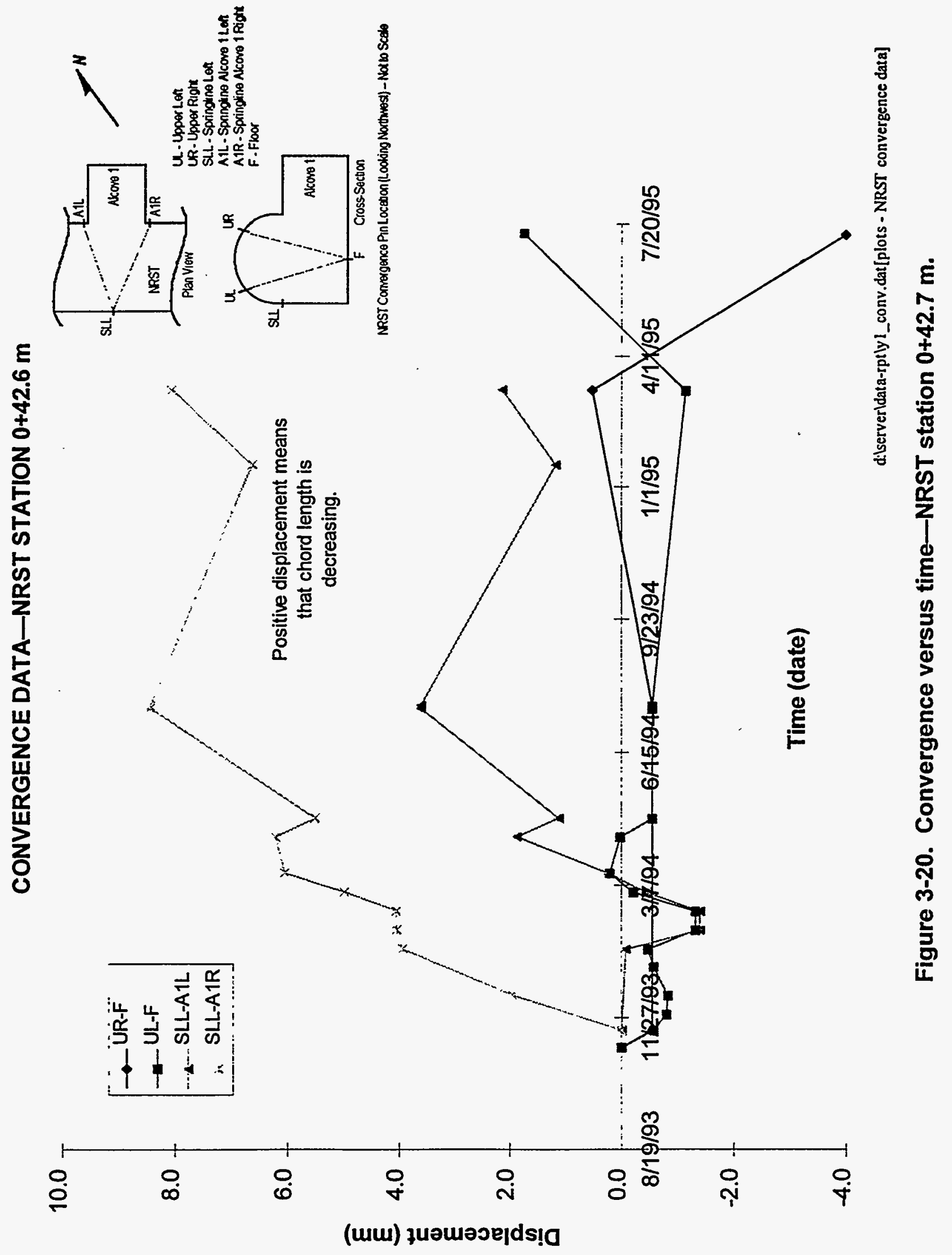




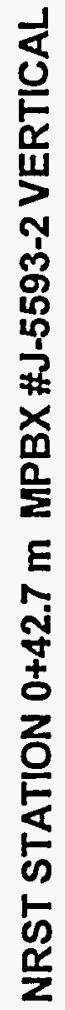

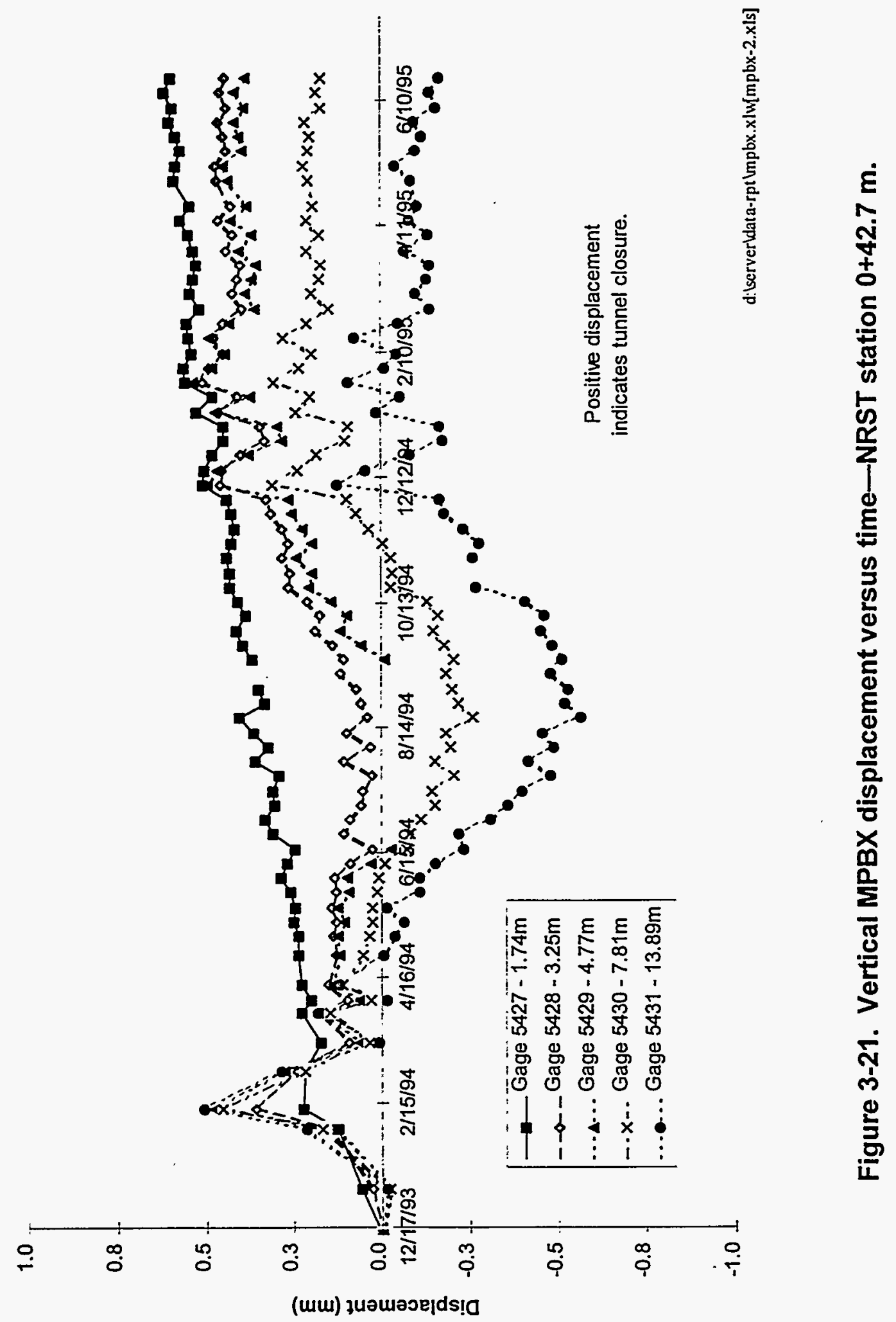


DISPLACEMENT RATE-NRST STATION 0+42.7 m MPBX \#J-5593-2 VERTICAL

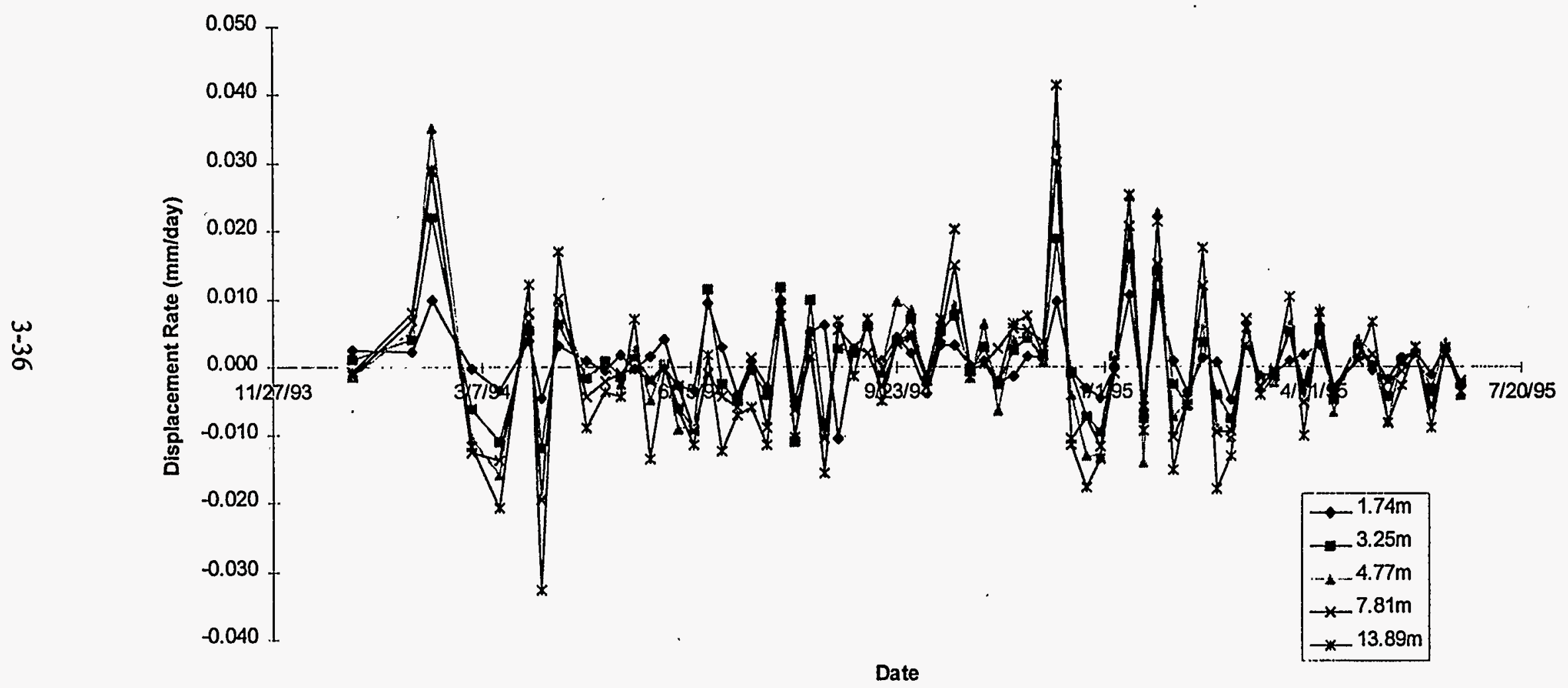

d:Lerverldata-rptumpbx.xlw[mpbx-2:x|s]

Figure 3-22. Vertical MPBX displacement rates versus time-NRST station 0+42.7 m. 


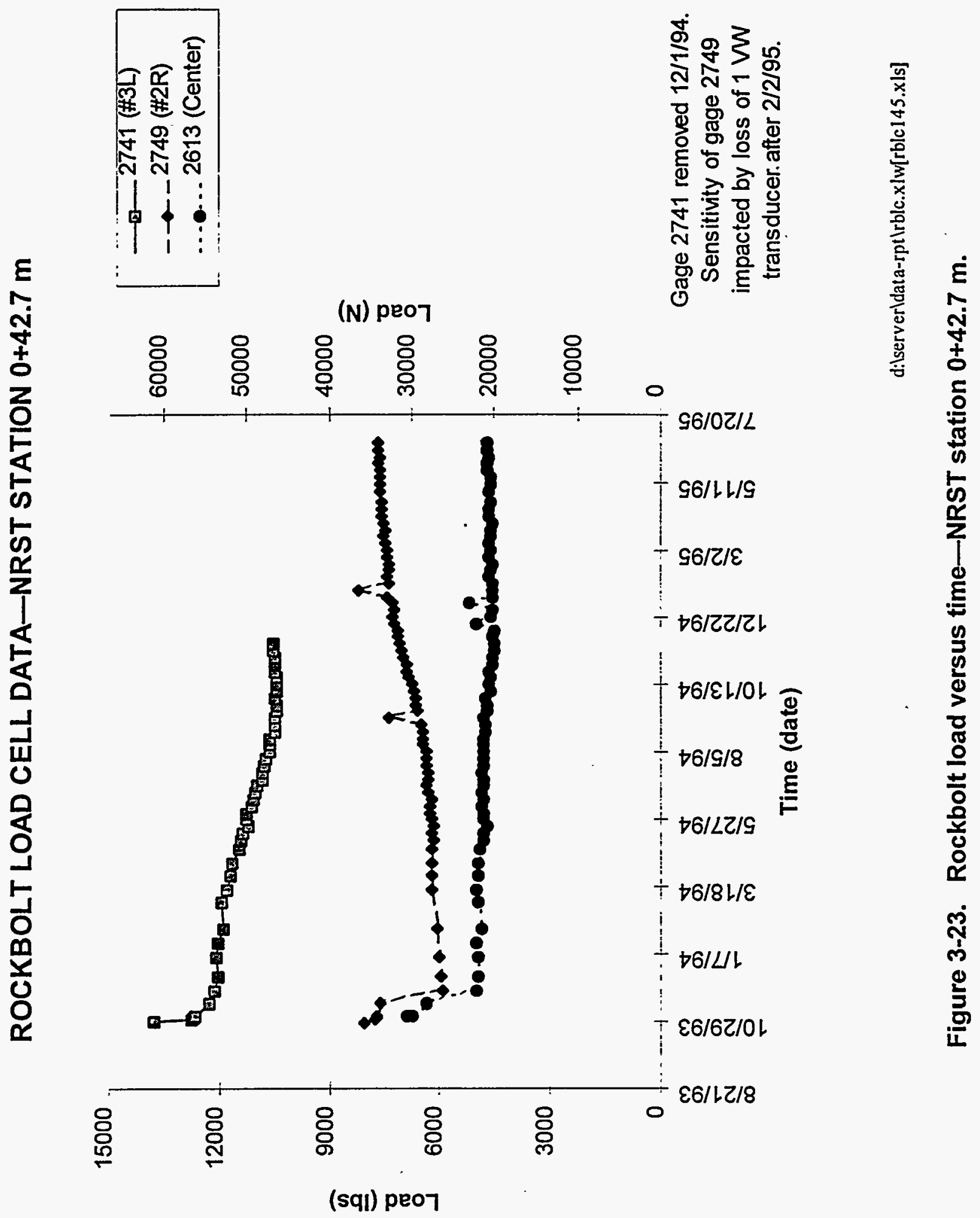


Rev 1

small with regard to the bolt strength. Peak installation load was $23.0 \%$ of the bolt yield strength. Rates of change in bolt load were low.

\subsubsection{Displacement and Rockbolt Load-NRST Station 0+56.3 m.}

Convergence data for station $0+56.3 \mathrm{~m}$ is presented in Figure 3-24. The two roof-to-floor chords exhibit similar patterns of closure with a peak value of $3.6 \mathrm{~mm}(0.140 \mathrm{in})$. The maximum rate of closure was $0.093 \mathrm{~mm} /$ day $(0.0037 \mathrm{in} /$ day), however, closure rates as calculated from the last two readings were zero for both chords. The horizontal chord showed a maximum closure of $1.4 \mathrm{~m}$ ( 0.056 in). Currently, only the roof-to-floor chords are being measured at this station because the spring line was covered by the concrete bearing structure shown in Section 2.3.5, Figure 2-12, used to launch the TBM.

Rock displacement as measured by the vertical MPBX at station $0+56.3 \mathrm{~m}$ is presented in Figure 3-25. This extensometer shows a consistent pattern of displacements between the anchors at each depth, however, the anchor at $3.25 \mathrm{~m}$ has the greatest displacement. The displacements at 4.77 and $7.81 \mathrm{~m}$ are also transposed. Typically, the deeper anchors will indicate greater displacement than shallower anchors if all deformations are due to rock deforming into the tunnel. The changes exhibited in Figure 3-25 are probably due to minute movements at anchors. This may be due to the irregularity of the hole due to the poor rock quality and the use of the Borros-type hydraulic anchors.

The maximum closure displacement was small up to July 1995 with a value of $2.35 \mathrm{~mm}$ (0.093 in). Rates of displacement calculated for seven-day intervals, shown in Figure 3-26, were a maximum of $0.005 \mathrm{~mm} /$ day (0.0002 in/day) from the most recent readings in June 1995.

The displacement record for the horizontal MPBX is presented in Figure 3-27. The pattern of change is very similar to that exhibited by the vertical anchor. A special verification 


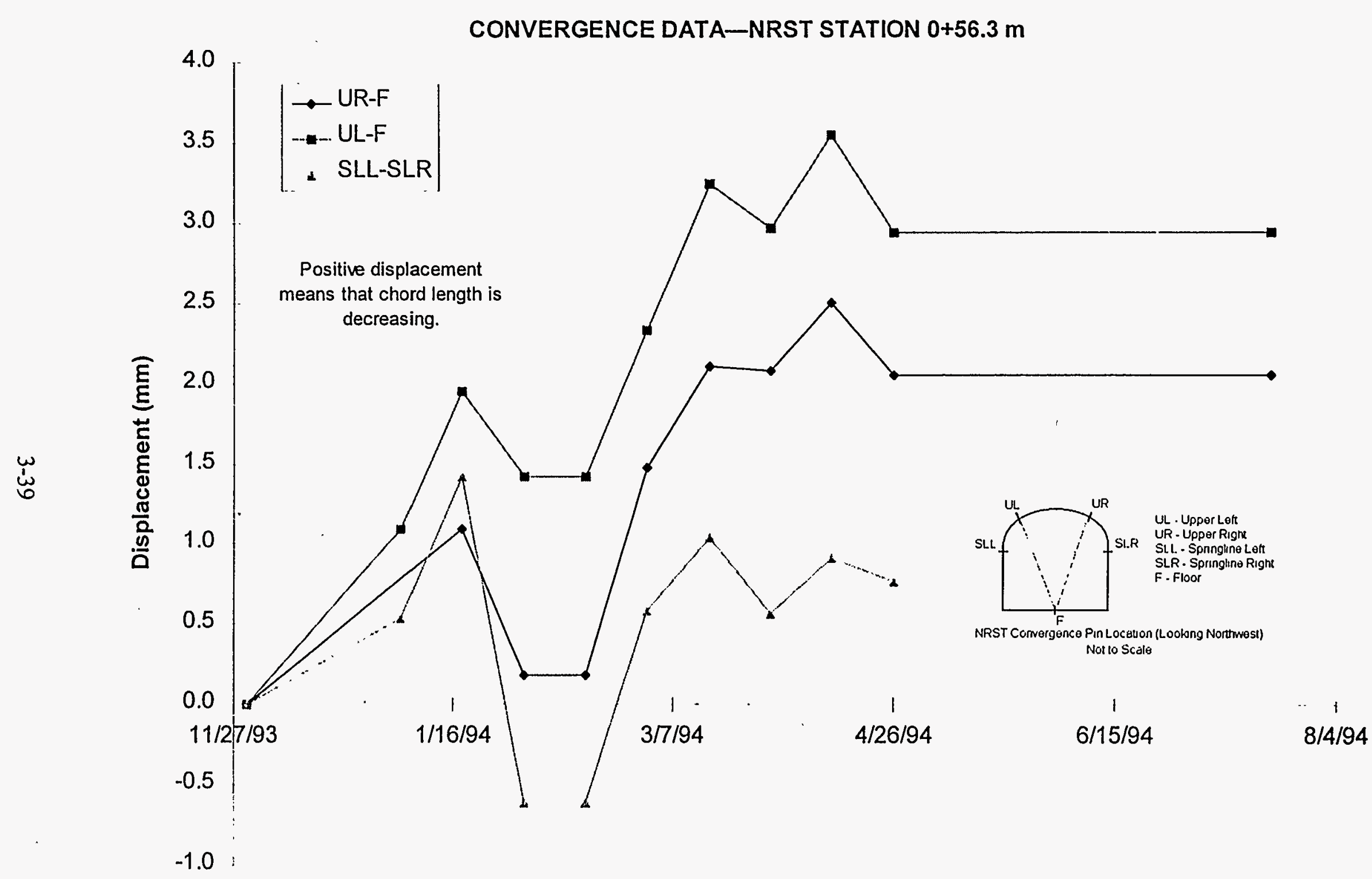

Time (date)

ditserverldata-rptly 1_conv, dat[plots - NRST convergence data]

Figure 3-24. Convergence versus time-NRST station $0+56.3 \mathrm{~m}$. 


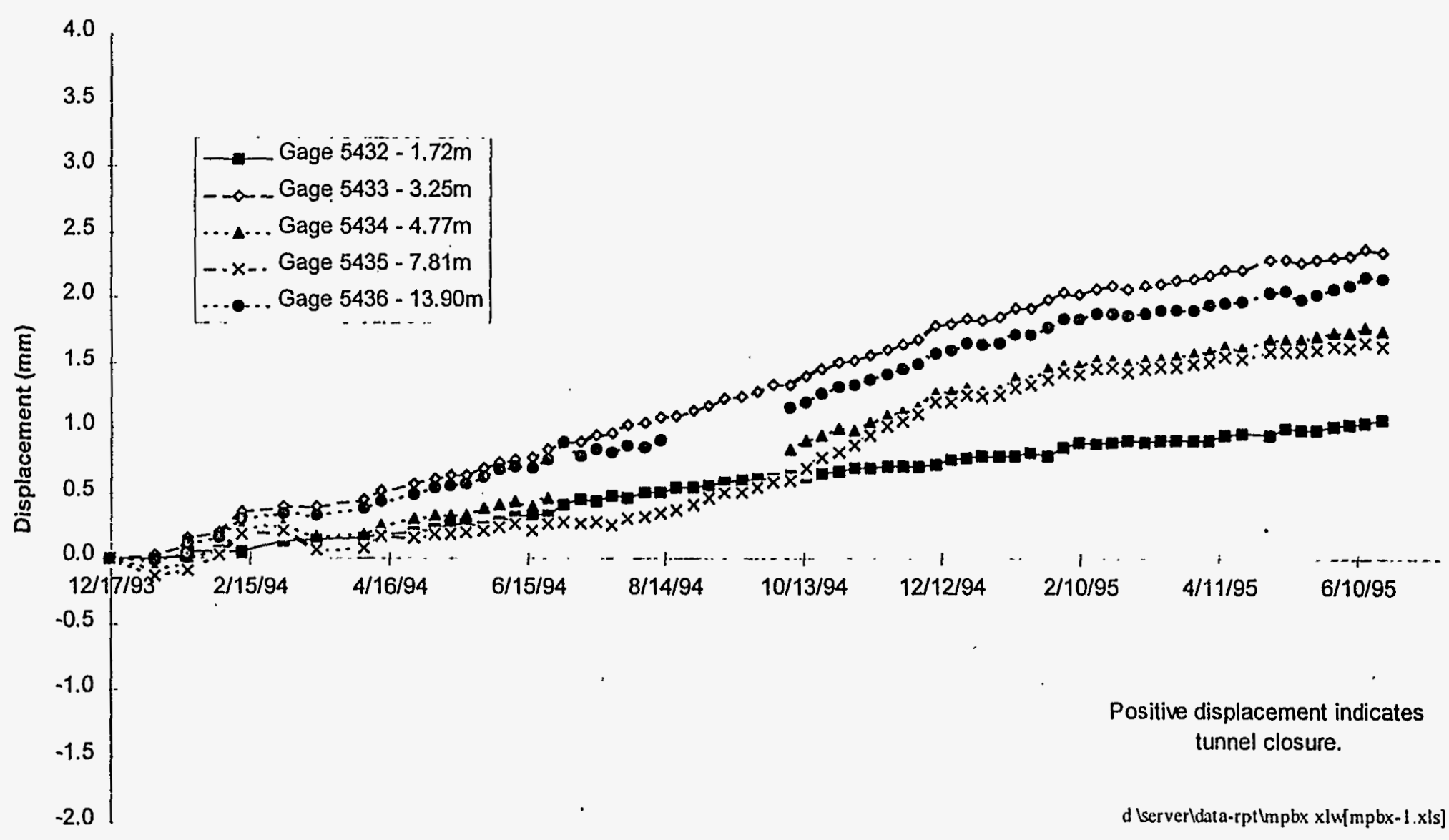

Figure 3-25. Vertical MPBX displacement versus time-NRST station $0+56.3 \mathrm{~m}$. 


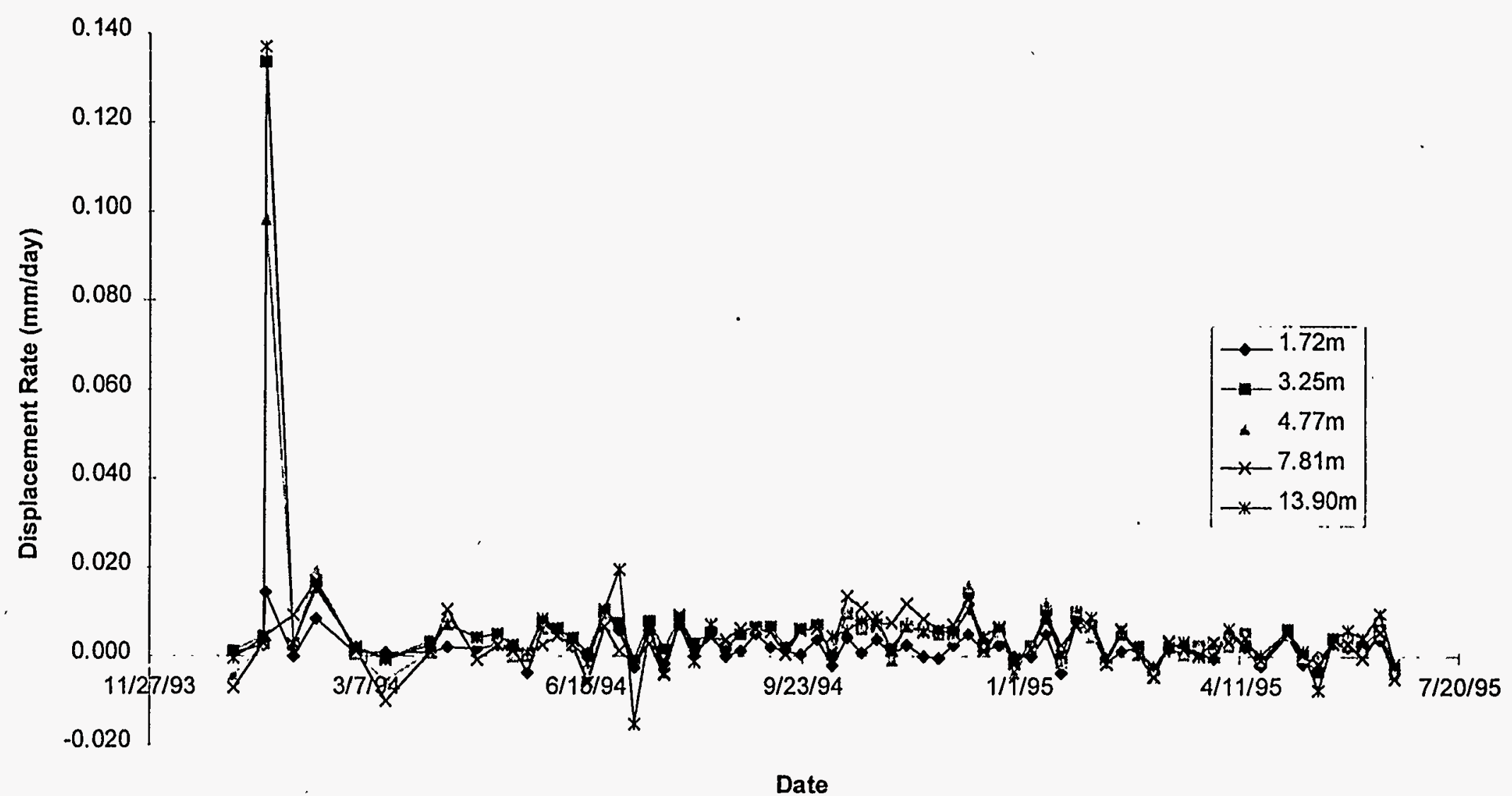

d:lserverldata-rptlmpbx.xlw[mpbx-1.xls]

Figure 3-26. Vertical MPBX displacement rates versus time-NRST station $0+56.3 \mathrm{~m}$. 


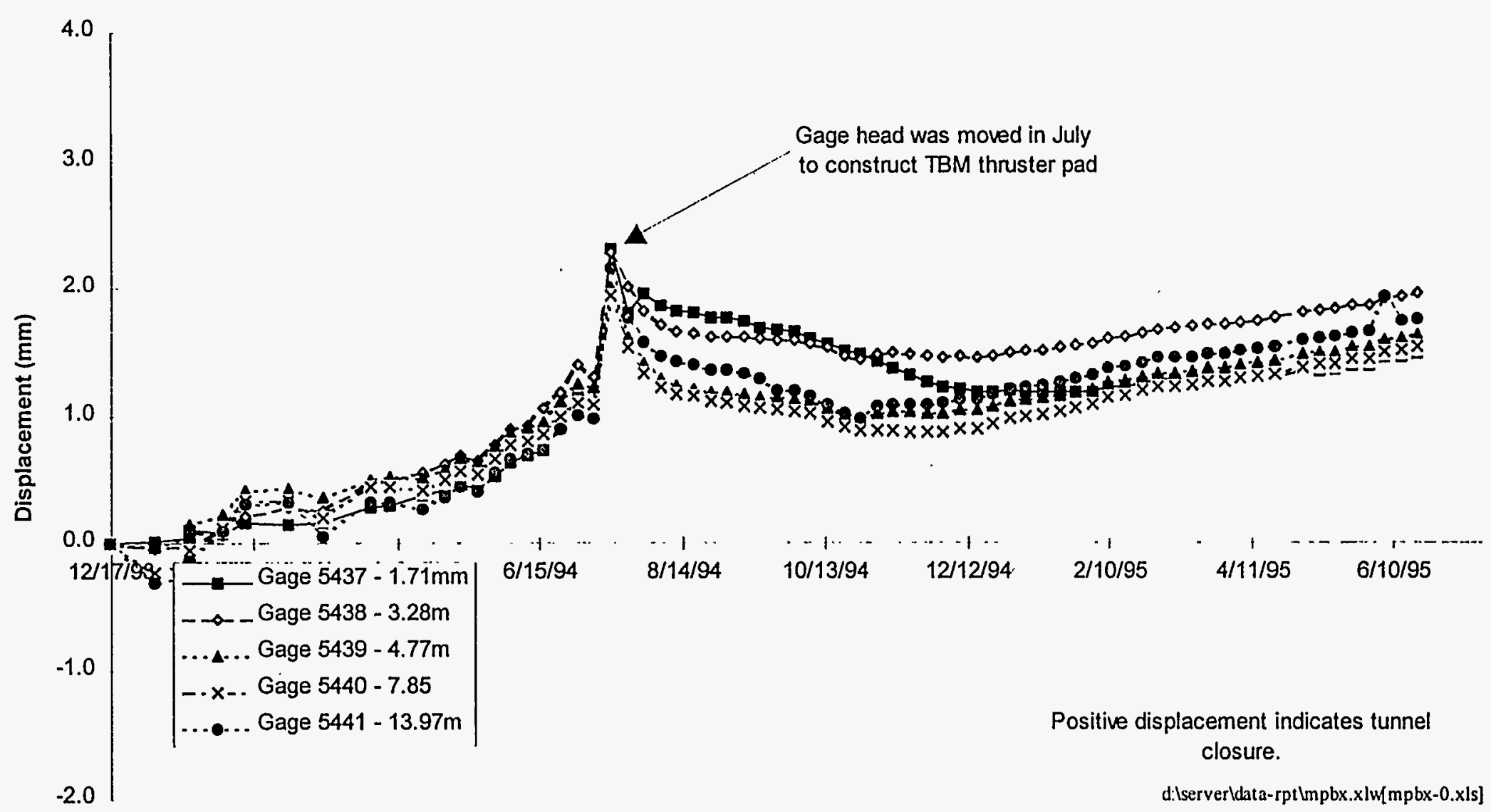

Figure 3-27. Horizontal MPBX displacement versus time-NRST station $0+56.3 \mathrm{~m}$. 
$\operatorname{Rev} 1$

exercise was therefore performed on all NRST MPBX instruments to assure that the association between individual transducers and the data acquisition system (DAS) output was correct. The physical verification confirmed the records. Displacements indicated initial closure up to à maximum of $1.41 \mathrm{~mm}(0.055 \mathrm{in})$ on June 30,1994 . The peak value was followed by a small decrease in all gages suggesting stabilization on July 7, 1994. At this time, the instrument head was disassembled to install extensions to the rods because the horizontal MPBX was located within the wall where the TBM thruster pad was to be constructed. A concrete form was inserted into the thruster pad to allow access to the MPBX. The record beyond July 7, 1994 reflects the adjustment of the instruments. The displacement then decreases until the end of 1994 and shows a general trend of increasing closure through June 1995. The total displacement is relatively small with a maximum value of $1.95 \mathrm{~mm}$ (0.077 in).

Displacements rates were calculated for seven-day intervals and are presented in Figure 3-28. The rates have reduced with time and were a maximum of $0.0035 \mathrm{~mm} / \mathrm{day}$ (0.0001 in/day) in June 1995.

Rockbolt load cells at station $0+56.3 \mathrm{~m}$ have all shown constant load levels with time as shown by Figure 3-29. Peak installation load was less than $16.0 \%$ of the yield load.

\subsubsection{Alcove No. 1}

\subsubsection{Alcove No. 1 Convergence Stations $0+4.6 \mathrm{~m}, 0+11.3 \mathrm{~m}, 0+17.7 \mathrm{~m}$} and $0+24.4 \mathrm{~m}$. The results of convergence measurements performed in Alcove No. 1 are presented in Figure 3-30 through 3-33. Convergence at each of the Alcove No. 1 stations display the same general pattern, with initial high rates of closure and with the closure curves tending to reverse by February 1995. The horizontal chord has shown the greatest change at all 
DISPLACEMENT RATE-NRST STATION 0+56.3 m MPBX \#J-5593-0 HORIZONTAL

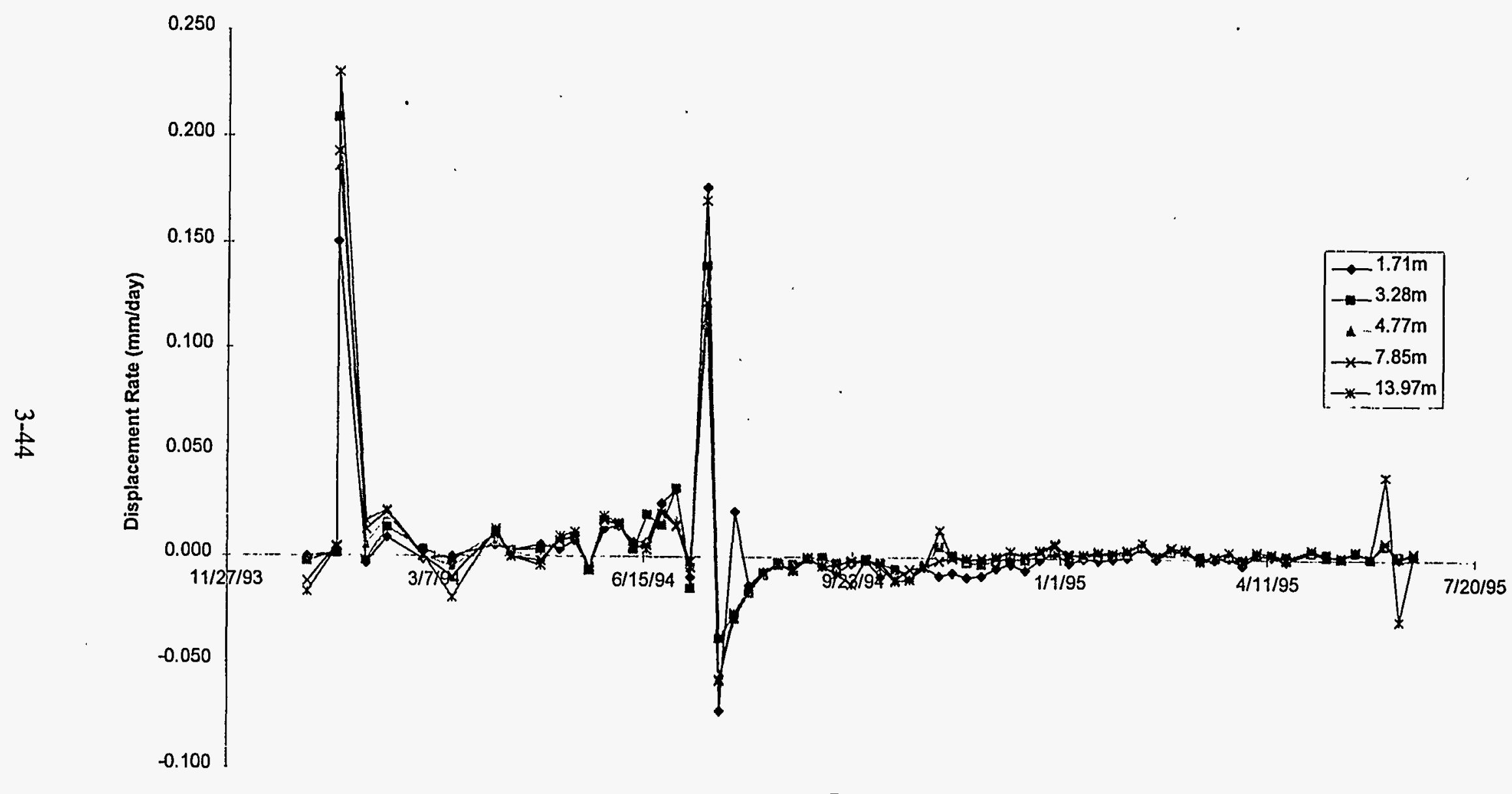

Date

dilserverldata-rptumpbx.xlwumpbx-0.xis]

Figure 3-28. Horizontal MPBX displacement rates versus time-NRST station $0+56.3 \mathrm{~m}$. 


\section{$s \boldsymbol{s}-\varepsilon$}

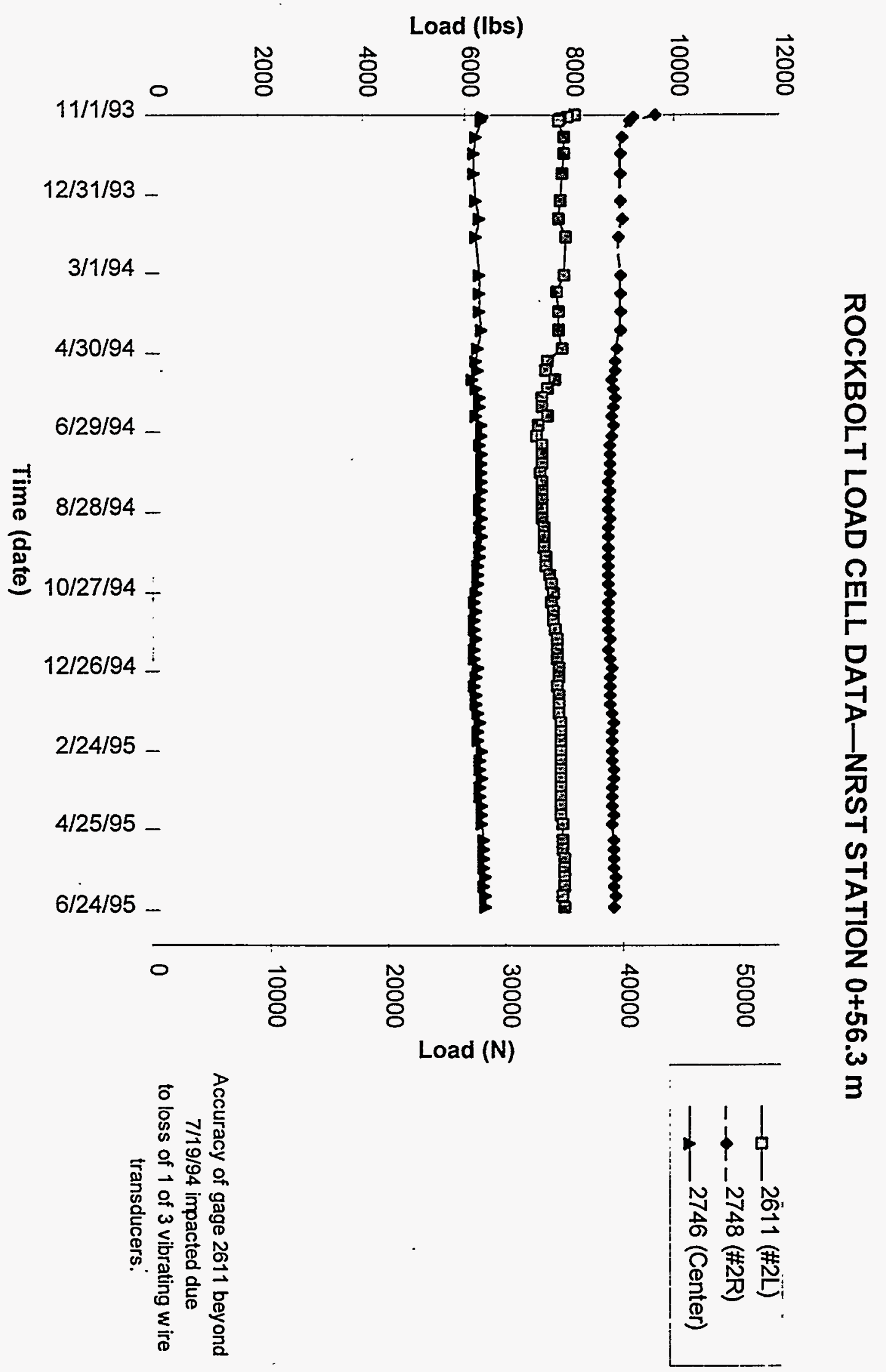




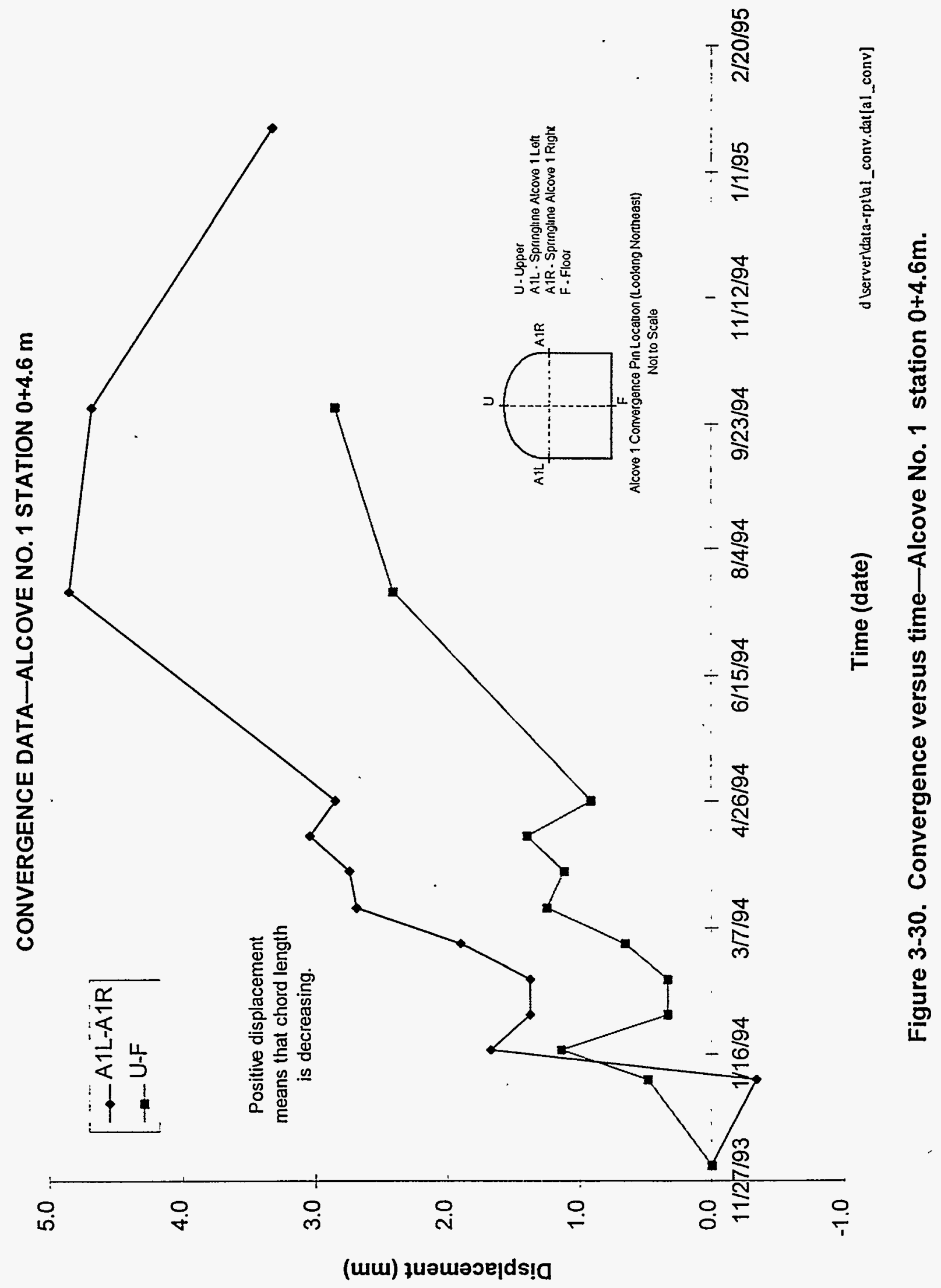




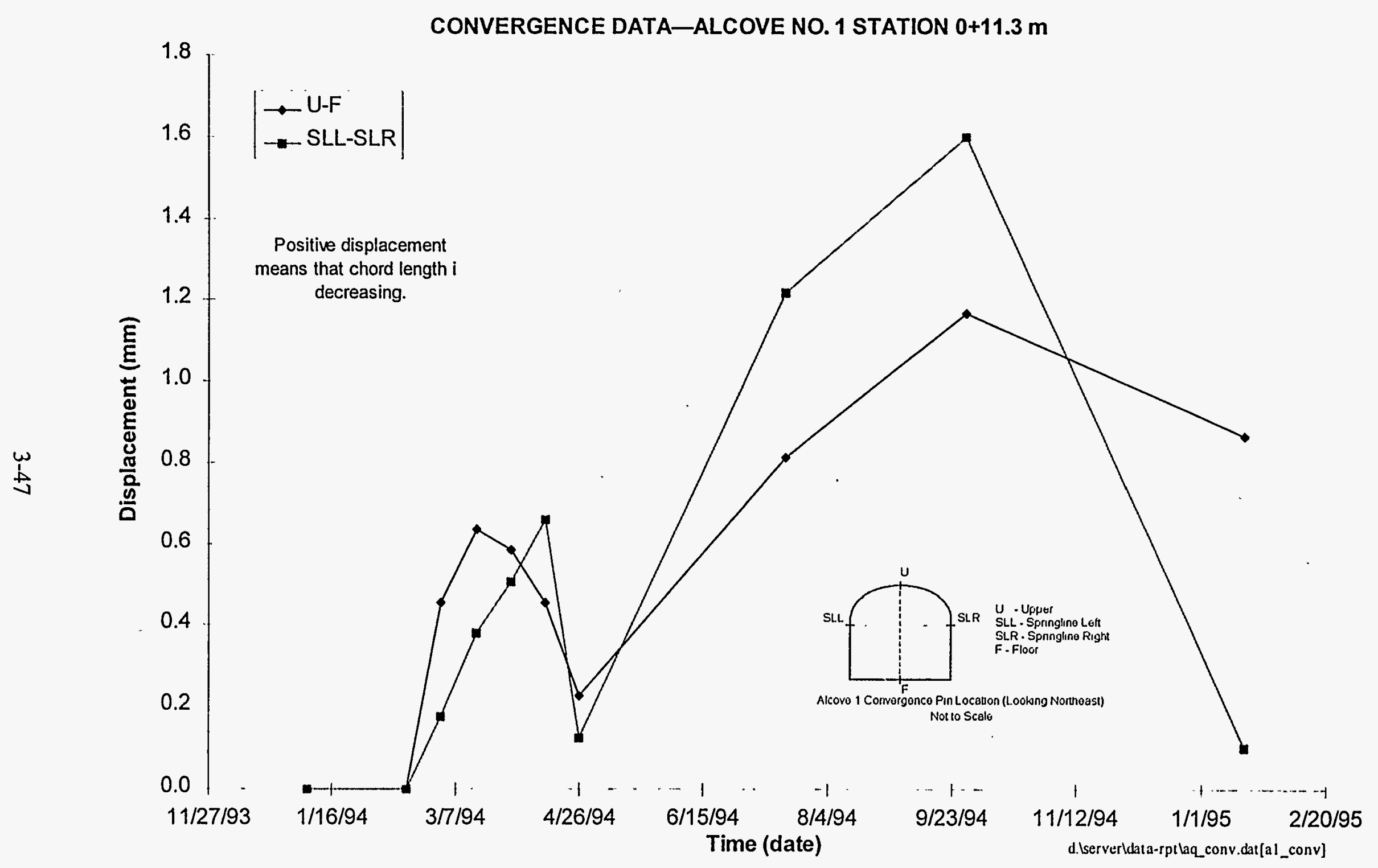

Figure 3-31. Convergence versus time-Alcove No. 1 station $0+11.3 \mathrm{~m}$. 


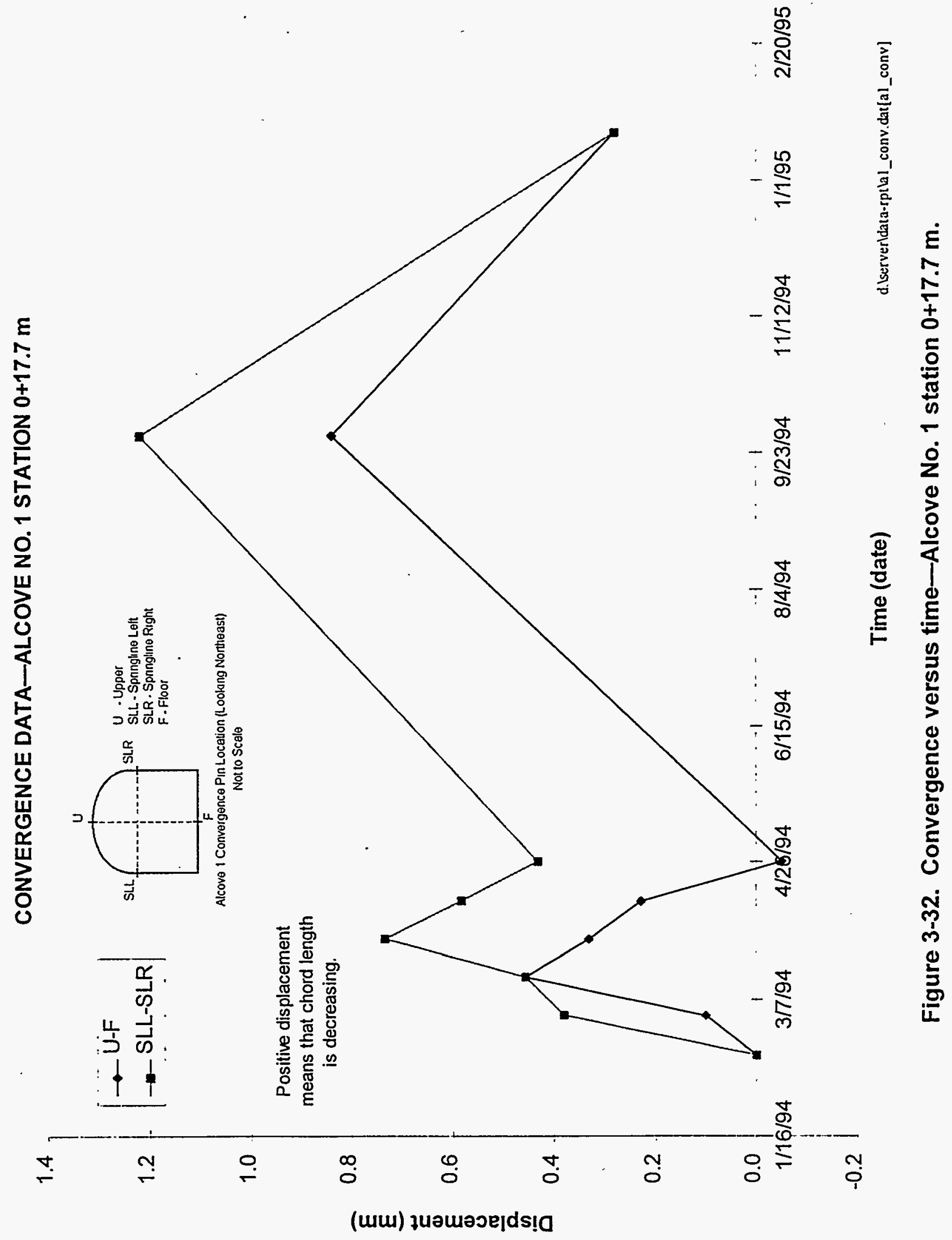


Rev 1

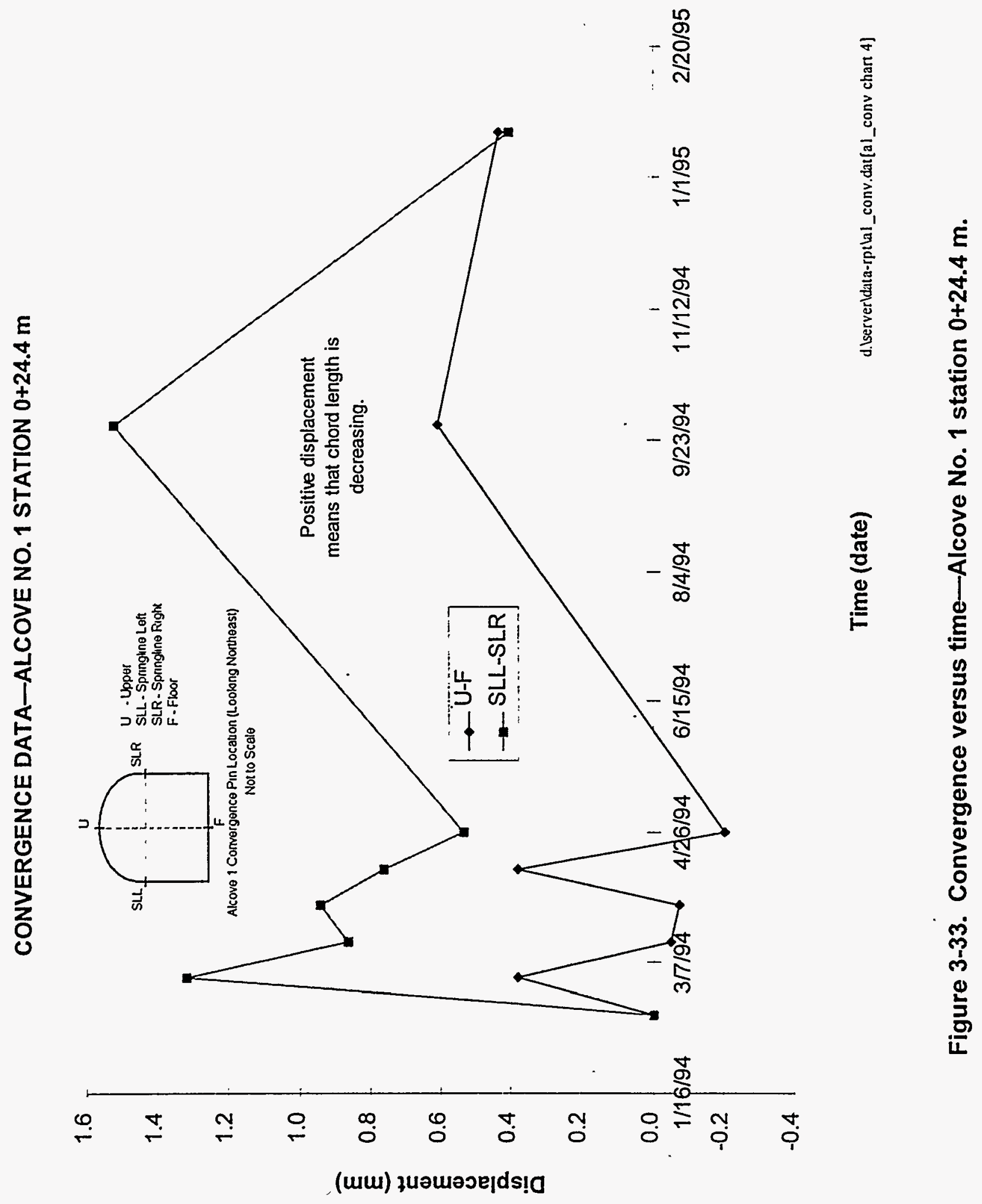


Rev 1

stations with a peak value of $4.85 \mathrm{~mm}(0.191 \mathrm{in})$ at Alcove No. 1 station $0+4.6 \mathrm{~m}$. The maximum vertical closure was at the same station and reached $2.85 \mathrm{~mm}(0.112 \mathrm{in})$. All stations have shown expansive changes in the most current readings, with the exception of the vertical chord at station $0+4.6 \mathrm{~m}$ which had a closure rate of $0.006 \mathrm{~mm} /$ day $(0.0002 \mathrm{in} /$ day).

\subsubsection{Alcove No. 1 Extensometer Data-Stations $0+11.3 \mathrm{~m}, 0+17.7 \mathrm{~m}$ and}

0+24.4 m. Extensometer data is presented in Figure 3-34 for the vertical MPBX at Alcove No. 1 station $0+11.3 \mathrm{~m}$ and the vertical single-point borehole extensometer (SPBX) at Alcove No. 1 station $0+24.4 \mathrm{~m}$. The instruments at both locations indicate closure in the vertical direction, with the maximum value equal to $2.1 \mathrm{~mm}(0.082$ in) occurring at the beginning of September 1994. A slight expansion then occurred, and closure at a reduced rate resumed in December 1994. Closure rates at the end of the monitoring period in June 1995 were -0.004 $\mathrm{mm} /$ day $(-0.0002 \mathrm{in} /$ day $)$ and $-0.002 \mathrm{~mm} /$ day $(-0.0001 \mathrm{in} /$ day $)$ at Alcove No. 1 stations $0+11.3$ and 0+24.4 m, respectively. Displacement rates are shown graphically in Figure 3-35.

The instrument at $0+17.7 \mathrm{~m}$ has produced unreliable data due to transducer malfunction.

\subsubsection{Instrumented Rockbolts-Alcove No. 1 Stations $0+4.6 \mathrm{~m}, 0+11.5 \mathrm{~m}$,} 0+14.0 m, 0+17.7 $\mathrm{m}$ and $0+23.8 \mathrm{~m}$. Load data for the instrumented rockbolts in Alcove No. 1 are presented in Figures 3-36 and 3-37. Bolts at Alcove No. 1 station $0+4.6 \mathrm{~m}$ include a crown bolt and a bolt located at the east rib. Both these instruments show initial tension bleed-off followed by some increase in load. At the end of the monitoring period, June 1995, the maximum indicated bolt load was $38.4 \mathrm{kN}(8,640 \mathrm{lbs})$. Yield strength of the IRBs is considerably lower than the that were used for permanent support. Due to reduction of area by the hollow center of the $19.1 \mathrm{~mm}$ ( $3 / 4$ in) type 1060 steel bolt required for insertion of the strain gage, yield strength is specified at $68.1 \mathrm{kN}(15,300 \mathrm{lbs})$. 


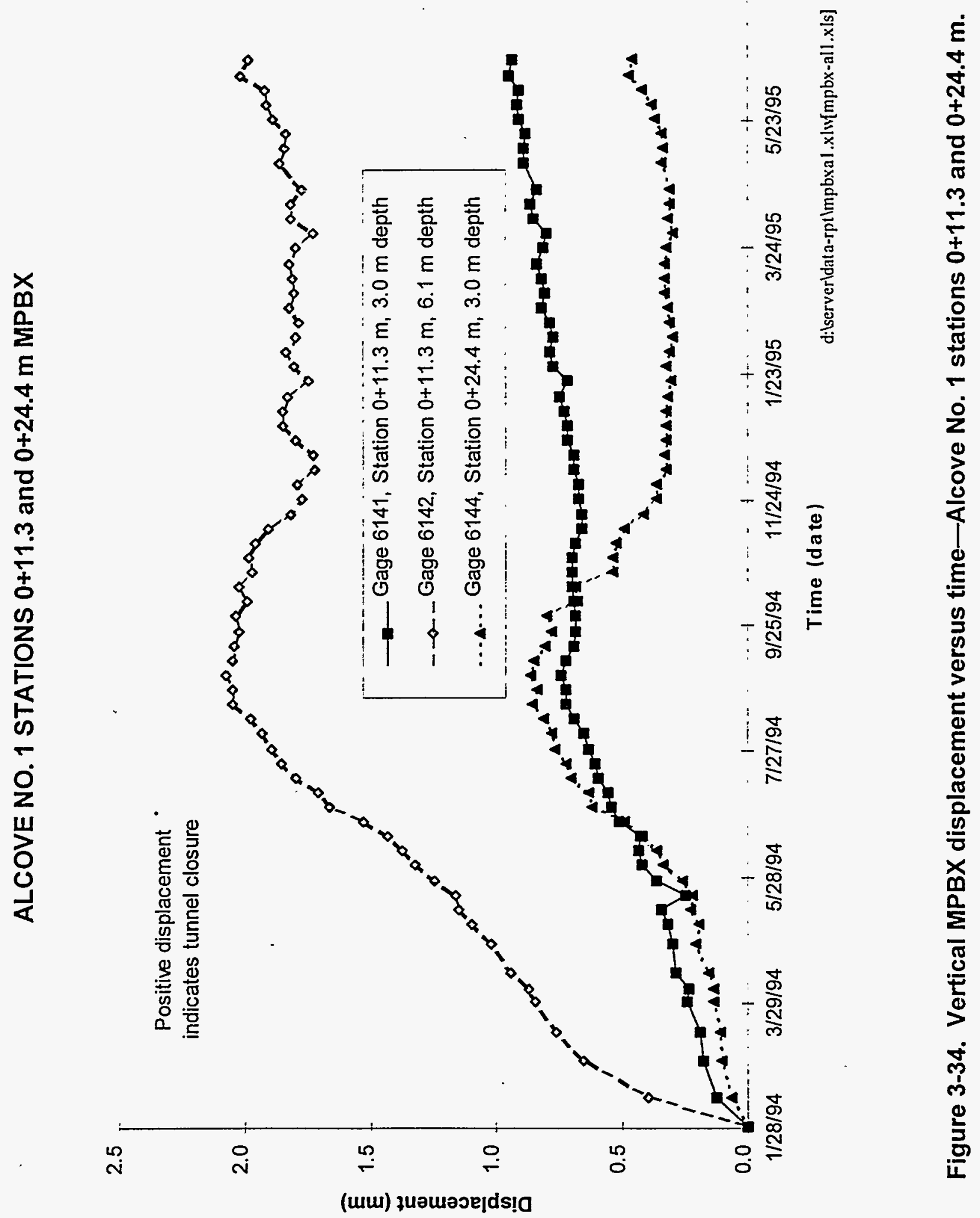




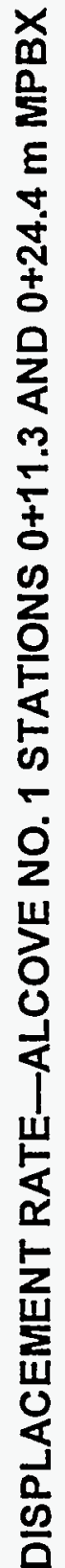

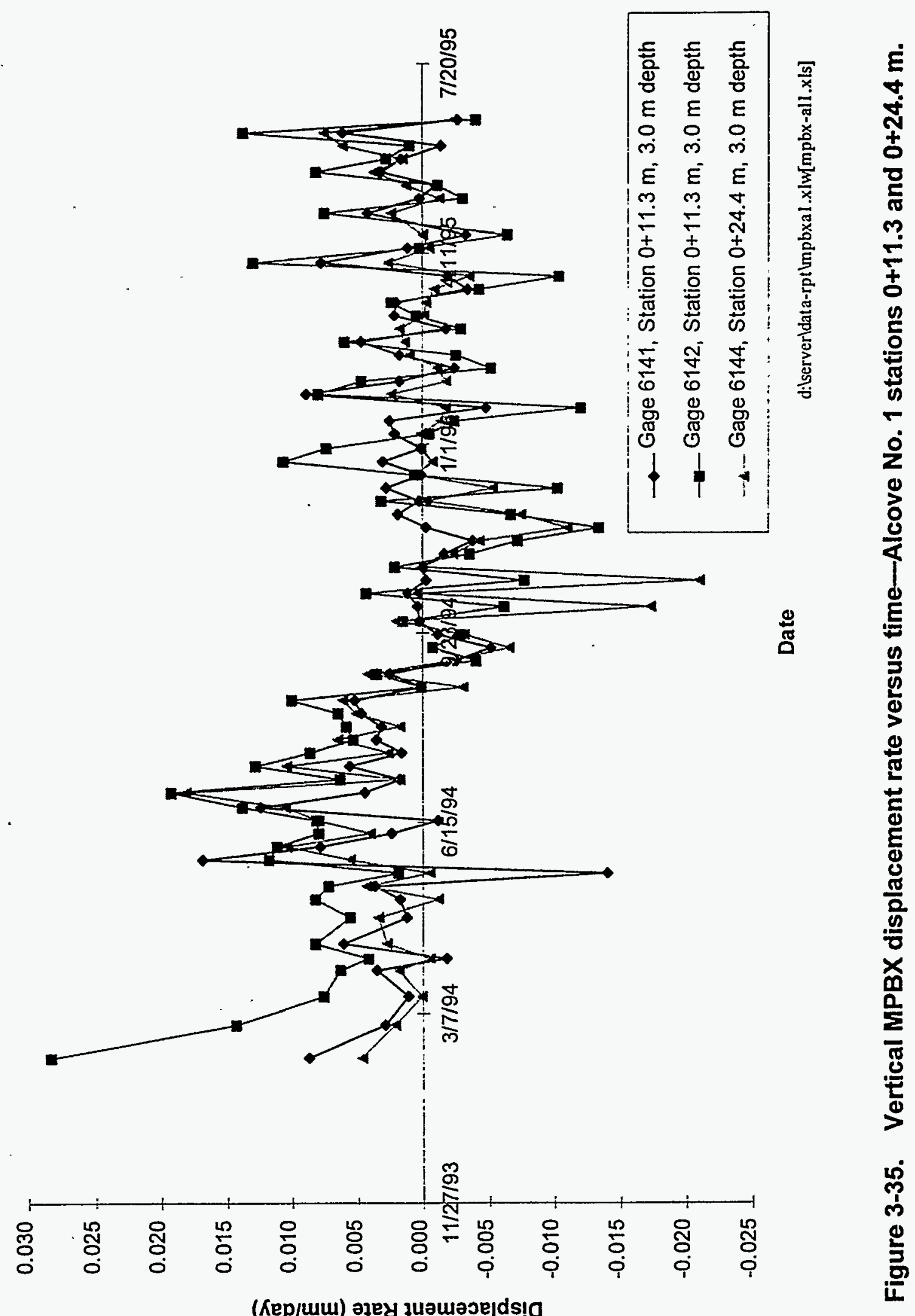


INSTRUMENTED ROCKBOLT-ALCOVE NO. 1 STATION $0+4.6 \mathrm{~m}$

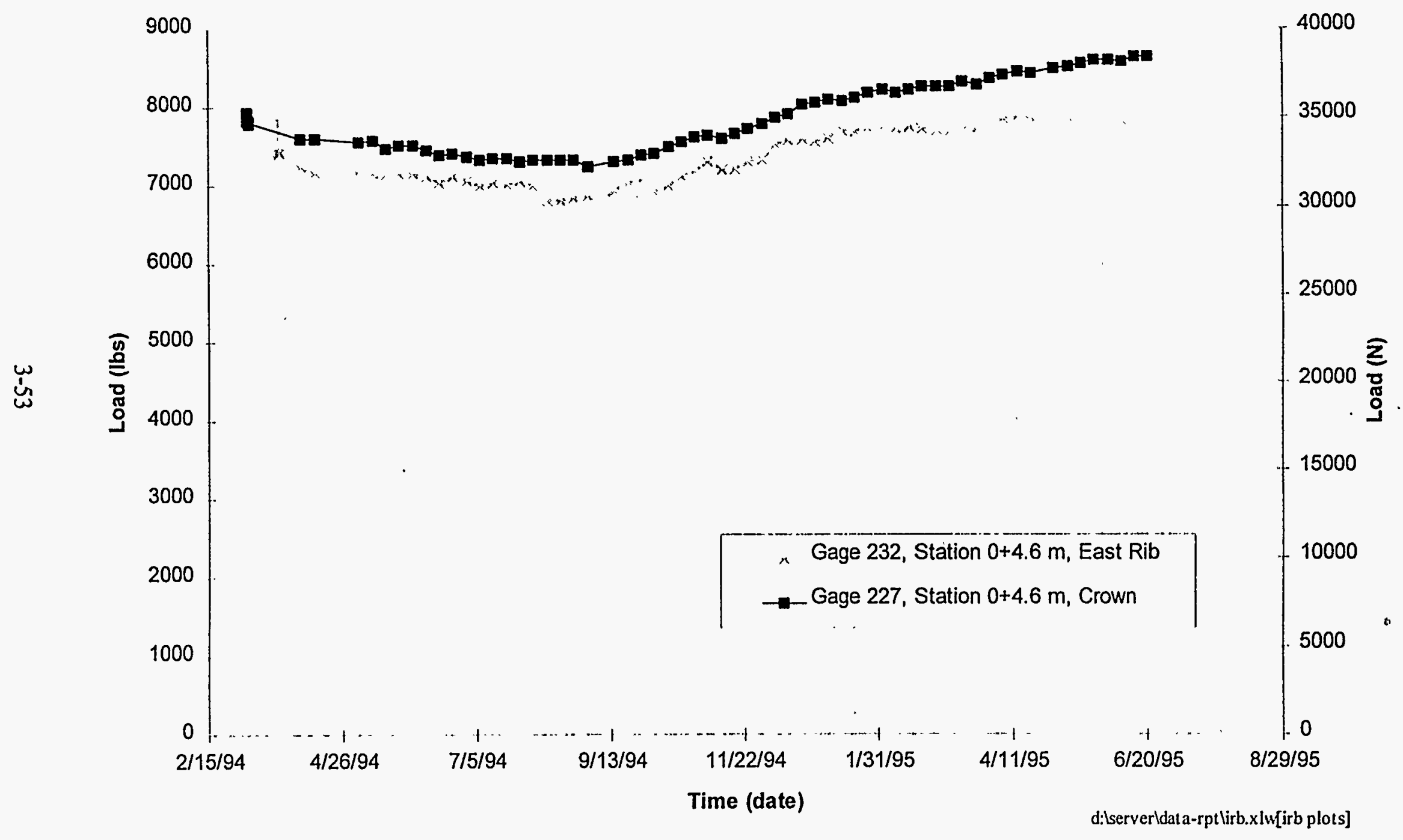

Figure 3-36. Rockbolt load versus time-Alcove No. 1 station $0+4.6 \mathrm{~m}$. 
INSTRUMENTED ROCKBOLT-ALCOVE NO. 1 STATIONS $0+11.5,0+14.0,0+17.7$ and $0+23.8 \mathrm{~m}$

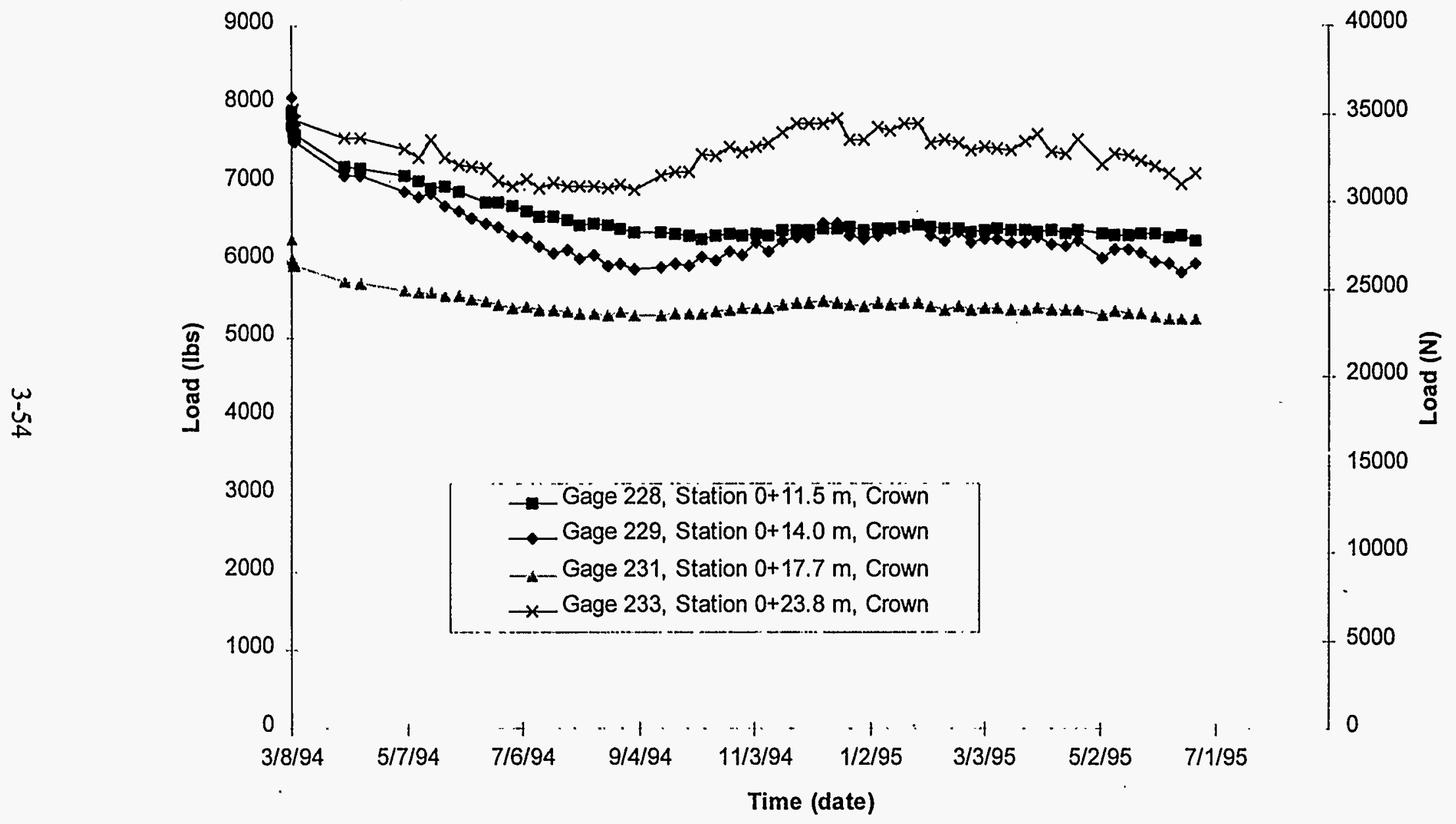

d:Iserverldata-rptlirb.xlw[irb plots]

Figure 3-37. Rockbolt load versus time-Alcove No. 1 stations $0+11.5,0+14.0,0+17.7$ and $0+23.8 \mathrm{~m}$. 
Rev 1

Similar levels of load and change in load are indicated for the bolts at Alcove No. 1 stations $0+11.5,0+14.0,0+17.7$ and $0+23.8 \mathrm{~m}$.

\subsection{Fibercrete Condition}

The condition of the fibercrete has been evaluated by inspection and mapping of cracks in August 1995. Mapping was performed by visual inspection using a tape referenced to known tunnel stationing. The mapping was limited to the north wall and crown in the Main Tunnel because the conveyor belt and ventilation line obscured the south wall and crown. Visual estimates of aperture width are noted on the maps. The resulting maps are presented in Appendix G.

The observed cracks appear to be primarily related to shrinkage and the installation of rockbolts, hangers and control boxes. They do not appear to be associated with structural conditions within the rock mass. There is no indication of excessive deformation or debonding.

\subsection{BHPC Response During TBM Mine-by}

BHPCs were installed at NRST station $0+60.2 \mathrm{~m}$ to attempt to monitor stress changes induced by the TBM as it excavated past the gages. Location and orientation of the gages was described in Section 2.3.5. The BHPCs were placed in three holes and oriented to measure vertical and horizontal stress change at increasing radial distances $(0.3$ to $1.5 \mathrm{~m})$ from the tunnel wall near the spring line. Change in stress near the tunnel wall would be induced by the advance of the tunnel past the BHPCs and later by the pressure exerted by the TBM gripper pads. 
Placement of the BHPCs was controlled by access limitations at the end of the NRST. Holes had to be drilled from the step between the NRST and machine-mined excavation at $0+60.2 \mathrm{~m}$. The holes had to be nearly parallel to the North Ramp alignment to allow measurement of the radial stress change.

The BHPCs were initially pressurized to levels estimated to be in the range of existing in situ stress, based upon the depth of the tunnel. The initial pressure (see Table 2-5) was used as the reference pressure and subsequent pressures reported as the change in pressure from the initial pressures. Figure 3-38 presents the pressure history of BHPC Nos. 1 and 2 for the period immediately before and after mine-by. Table 3-5 lists the schedule of TBM advance for a distance of $14.2 \mathrm{~m}$ from the end of the NRST. BHPC response was heavily impacted by the temperature variations which produced daily pressure changes on the order of $0.3 \mathrm{MPa}$ (50 psi) or roughly $40 \%$ of the vertical stress expected at this depth. No stress relief was detected as the TBM sumped in and cut to 0+63 m. Data for BHPC Nos. 1 and 2 for this period are presented in Figure 3-38, and show no detectable offset within the pattern of the daily temperature-induced changes.

Bleed-off of pressure had reduced the internal pressure in the BHPCs to near zero. The BHPCs were, therefore, repressurized on October 4, 1995. This repressurization was followed by rapid pressure reduction which may have masked stress changes as the TBM advanced beyond the gage locations between October 6 and October 17, 1994. Typically, the pressure in a BHPC will decrease for some period of time after repressurization and then stabilize. Both BHPCs Nos. 1 and 2 show this behavior after repressurization. Because mining commenced immediately after the repressurization, the pressure record of the response of the BHPCs to mining was difficult to interpret. 


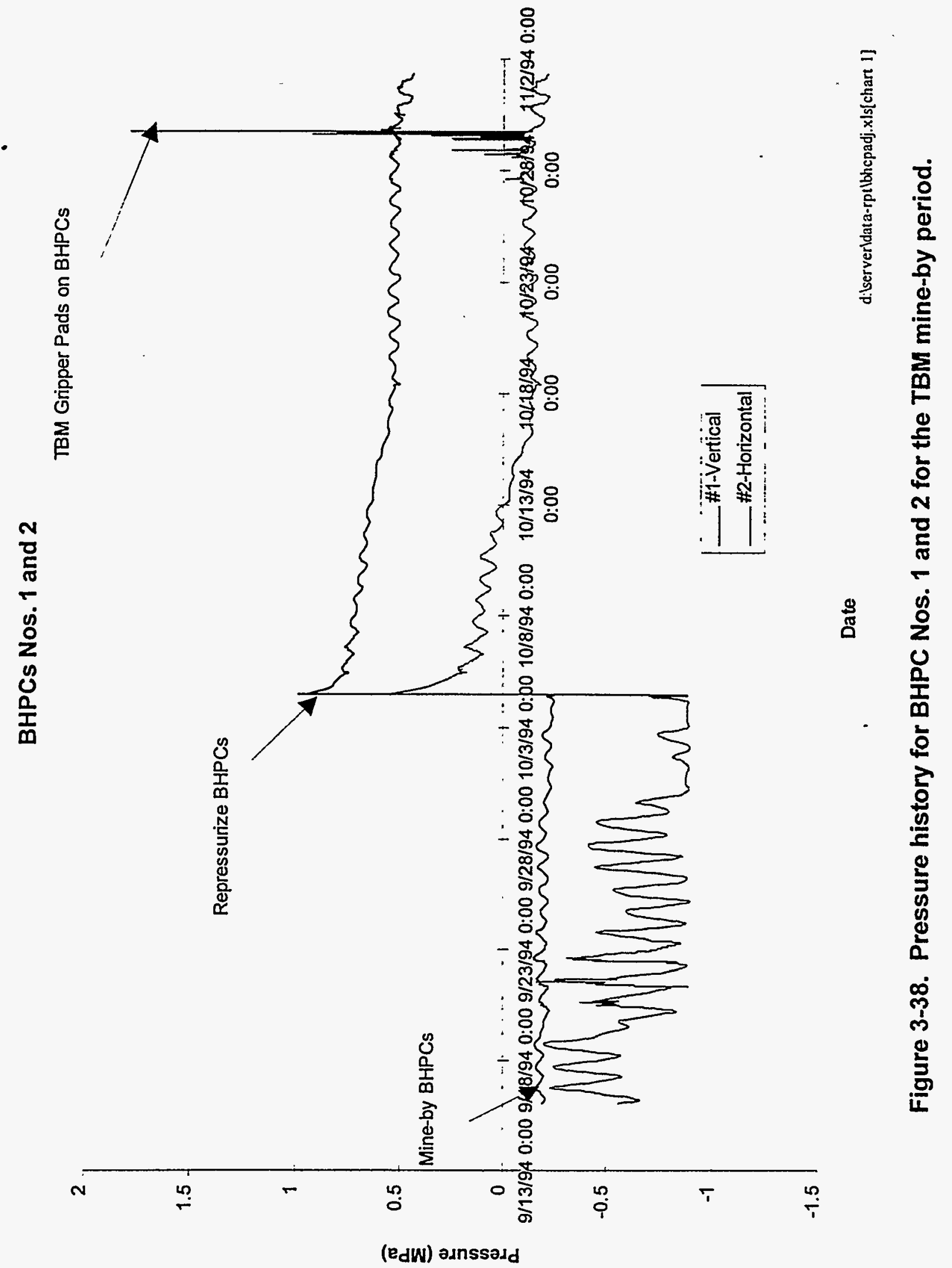


Rev 1

\section{Table 3-5. Schedule of TBM Advance Between $0+60.2$ and $0+74.4 \mathrm{~m}$}

\begin{tabular}{cccl} 
Date & $\begin{array}{c}\text { TBM Penetration } \\
(\mathbf{m})\end{array}$ & $\begin{array}{c}\text { Location of Face } \\
(\mathbf{m})\end{array}$ & \multicolumn{1}{c}{ Comments } \\
\hline $9-19-94$ & 0.00 & $0+60.2$ & \\
$9-20-94$ & 1.88 & $0+62.1$ & $\begin{array}{l}\text { Start excavation, mine-by BHPC Nos. 1, 2, } \\
\text { 3 and 4. }\end{array}$ \\
$9-21-94$ & 0.81 & $0+62.9$ & $\begin{array}{l}\text { Mine-by BHPC Nos. 5 and 6. } \\
9-22-94\end{array}$ \\
$10-5-94$ & 0.14 & $0+63.0$ & TBM stopped for adjustment. \\
$10-6-94$ & 1.62 & $0+64.7$ & Repressurized BHPCs 10-4-95. \\
$10-10-94$ & 0.60 & $0+65.3$ & \\
$10-17-94$ & 0.59 & $0+65.9$ & \\
$10-27-94$ & 0.48 & $0+66.3$ & \\
$10-28-94$ & 1.80 & $0+68.1$ & \\
$10-29-94$ & 1.30 & $0+69.4$ & TBM gripper pads directly over gages. \\
$10-30-94$ & 3.75 & $0+73.1$ & \\
$10-31-94$ & 0.27 & $0+73.4$ & \\
\hline
\end{tabular}

The BHPC pressure stabilized prior to the time at which the TBM gripper pads were directly next to the BHPCs. Each pressure response of BHPC Nos. 1 and 2 to the gripper pad pressure occurred on October 28, 29 and 30, 1994, after which no response was indicated.

The effects of the TBM gripper pads on the BHPCs are shown in Figures 3-39 and 3-40 for the horizontal (radial) and vertical stress changes, respectively. Gripper pad effects became apparent in the horizontal direction as early as October 28, 1994 and were greatest in BHPC No. 2 which was nearest the tunnel perimeter. The greatest change occurred on October 29, 1994 when the gripper pad was immediately over BHPC No. 2. A similar, large change occurred in BHPC No. 3 immediately after response from BHPC No. 2 stopped. BHPC No. 5, located farthest from the tunnel wall, showed very little response. 


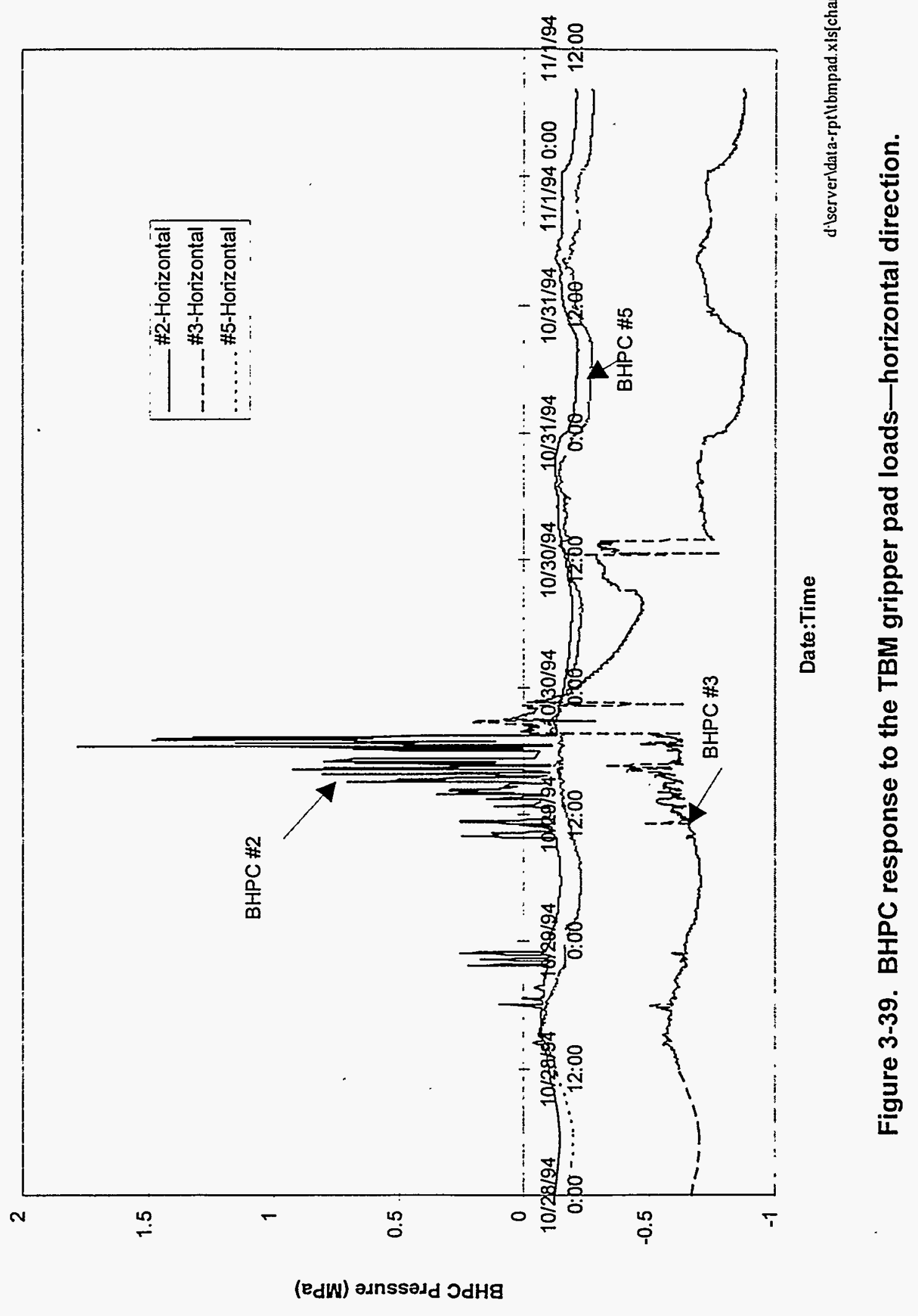




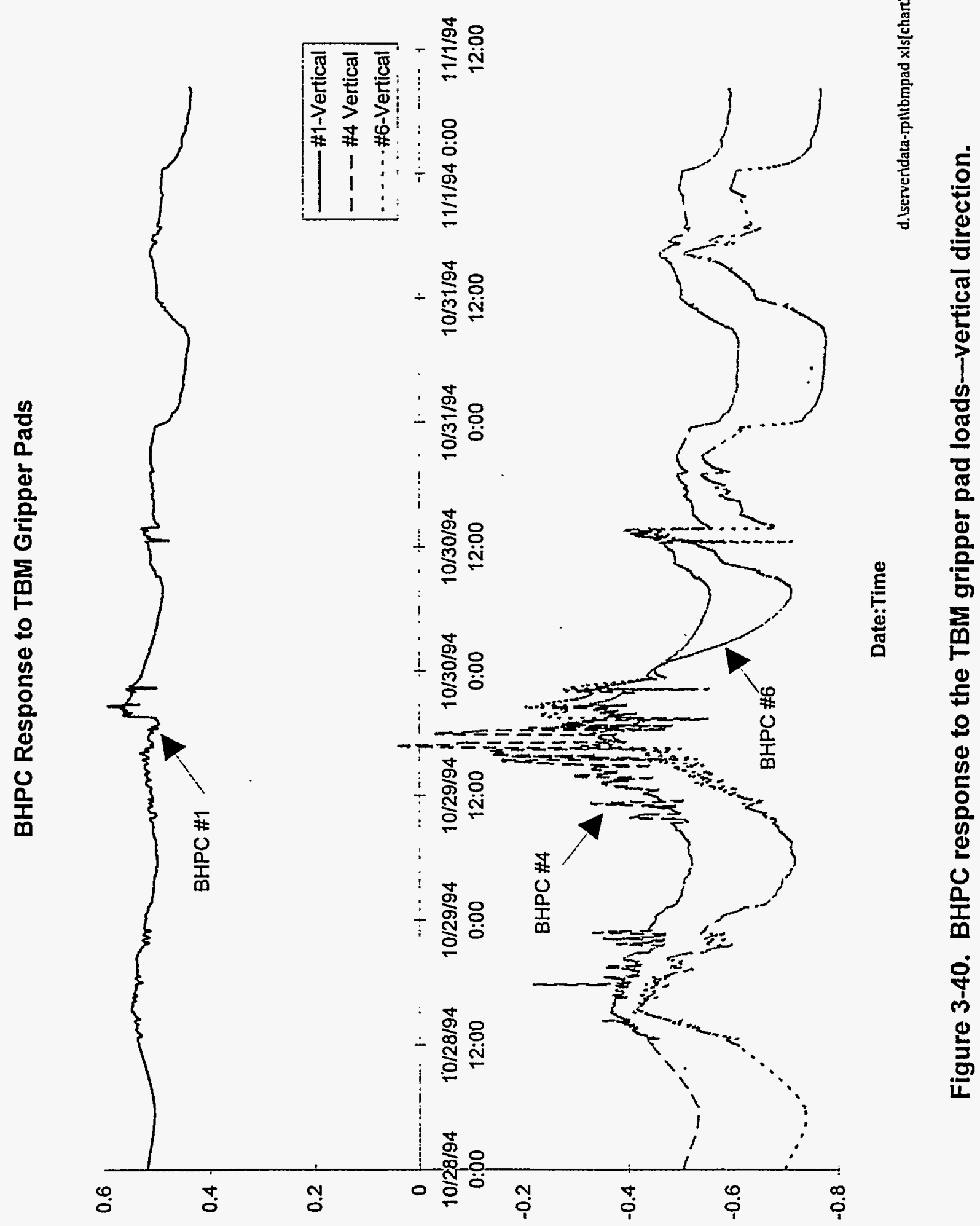

(EdW) adnssadd OdHG 
The vertical stress change was less pronounced, as shown in Figure 3-40. BHPC No. 1, closest to the tunnel wall, showed the smallest response with the deepest gages showing the greatest change.

The rock in the area of the BHPC installations was effected by the presence of a large fractured zone that crosscut the NRST face and passed into the north rib just beyond the BHPCs, as shown in Figure 3-41. The existence of this large structure may have impacted the changes of stress that occurred when the TBM mined past the gage, and may have impacted stress distribution during application of the gripper pads. 


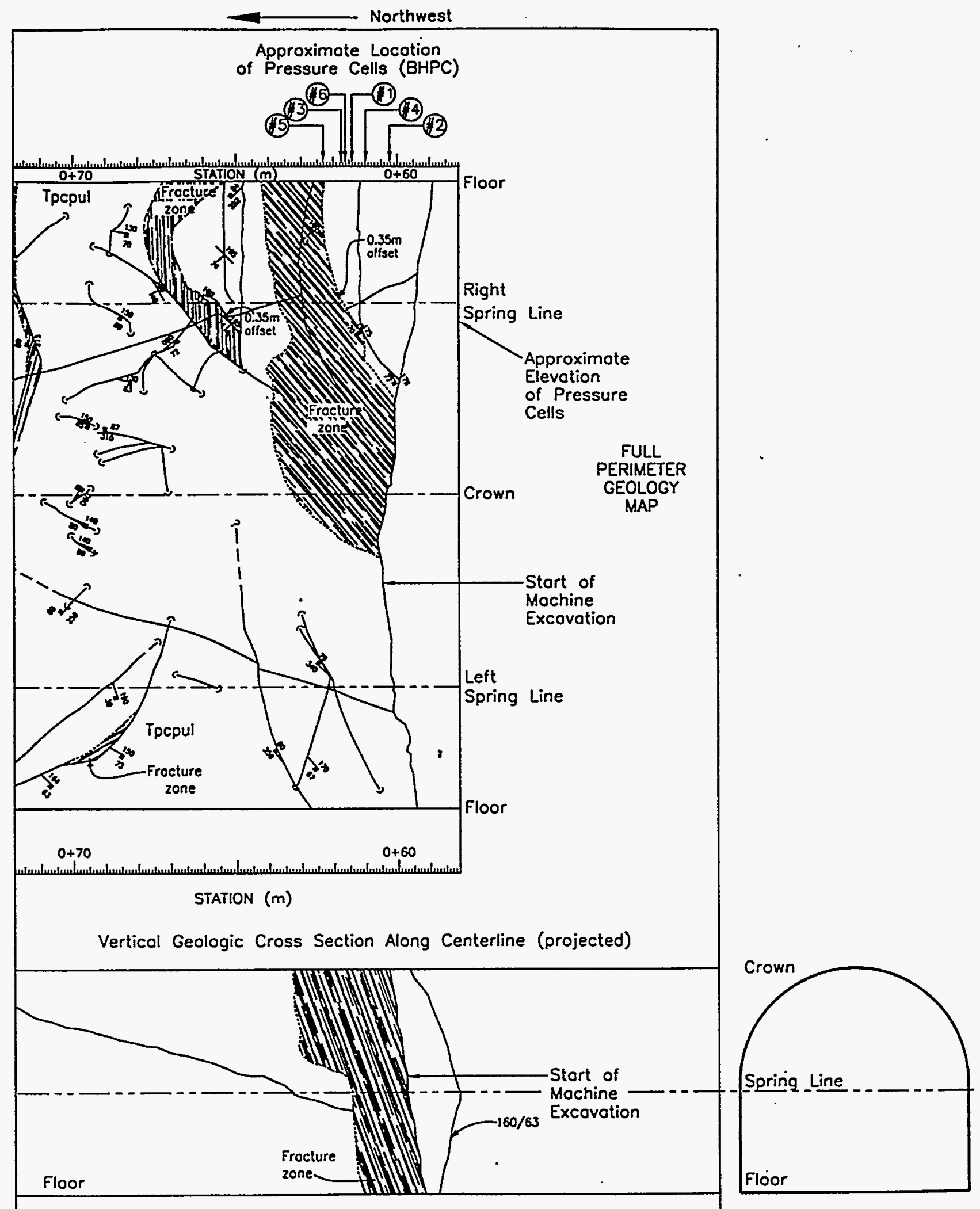

Figure 3-41. Structural geology of the North Ramp in the vicinity of the BHPCs (from detailed line survey from North Ramp of the ESF, stations $0+60 \mathrm{~m}$ to $4+00$, U.S. Bureau of Reclamation, DTN: GS950508314224.002. 


\subsection{North Ramp Starter Tunnel-Design/Performance Verification}

\subsection{Introduction}

The monitoring activities performed in the In Situ Design Verification studies are conducted to satisfy requirements in 10 CFR 60, subpart F-Performance Confirmation Program $\S 60.141$ Confirmation of Geotechnical and Design Parameters. This section of the Code of Federal Regulations requires a "continuing program of surveillance, measurement, testing, and geologic mapping shall be conducted to ensure that geotechnical and design parameters are confirmed..." It also specifies that "as a minimum, measurements shall be made of rock deformations and displacement changes, changes in rock stress and strain...," and that "these measurements and observations shall be compared with the original design bases and assumptions" to determine if there is a need for modifications of design or construction methods.

Data produced by the design verification activities are identified as repository design data needs (TRW 1995) in the areas of:

- deformation around openings (3.8.1),

- convergence around openings (3.8.2), and

- ground support load and deformation (3.8.3).

The results of the NRST monitoring support the assessment of "Rock Mass Performance Parameters" for the evaluation of emplacement drift design and for development of acceptance criteria for subsurface openings. 
Rev 1

The functional requirements of the NRST make stability mandatory because it will provide the only access to the ESF until completion of the Main Drift and South Ramp. As part of the ESF permanent structures, systems, and components, the NRST is required to have a maintainable service life of 100 years (DOE 1995). It therefore controls the progress of all activities associated with ESF construction and testing in the early phases of site characterization. The NRST monitoring provides a basis to assess overall stability, to indicate requirements for maintenance, and to verify success of any maintenance efforts.

Although rock stability is a requirement in several 10 CFR 60 regulations, they do not provide specific ranges that are needed to judge performance. Initial project-imposed goals were defined in the Site Characterization Plan (SCP) (DOE 1988). These tentative goals were summarized by Hardy and Bauer (1991) as a basis for evaluating the YMP Drift Design Methodology and are presented in Table 4-1. Assuming the NRST is a main access excavation, the goals will be used as a basis to evaluate the data observations contained in this report. Other criteria from the general tunneling industry will also be discussed as a basis of comparison.

\subsection{Monitoring Mining Methods-Blast Monitoring}

During construction of the NRST, the monitoring mining methods (construction monitoring) experiment was confined to monitoring ground motion (PPV), as well as observational assessments of overbreak and damage in the rock surrounding the openings. 
Rev 1

\section{Table 4-1. Stability Performance Measures and Goals for Repository Drifts (Hardy and Bauer 1991)}

\section{Performance \\ Measure}

Limit rock damage

\section{Tentative Goal from SCP} (DOE 1988)

\author{
Impact \\ on Design
}
Overbreak $<15 \mathrm{~cm}$ average
Measurable excavation-
technique-induced damage limited to
within $1 \mathrm{~m}$ of the excavation*

Selection of construction methods

Closure
Access drifts
Closure rate $<1 \mathrm{~mm} / \mathrm{yr}$
Total closure in ramps $<7 \mathrm{~cm}$ in $100 \mathrm{yr}^{\dagger}$
Conservative ground support
Conservative ground support

Rock Fall

Main access drifts No rock falls

Conservative ground support design

Maintenance

Main access drifts Inspection and minor maintenance will be performed on a continuing basis

Major maintenance frequencies $* *>100$ yr Selection of ground support materials, conservative design

* SCP recommends blast-induced fracture extent into intact rock $<7.5 \mathrm{~cm}$ average.

† Deformation expected to be significantly less.

$¥$ Not currently in SCP, recommended by Hardy and Bauer (1991).

** SCP recommends > 25 yr, value of 100-yr recommended by Hardy and Bauer (1991).

Both the NRST main tunnel and Alcove No. 1 were excavated using the drill-and-blast mining method. Controlled blasting procedures were implemented to minimize blast-induced damage to the excavation perimeter. Blast damage can result in loosening of the surrounding rock mass which increases ground support requirements and long-term maintenance. Specific Nuclear Regulatory Commission (NRC) regulatory language, 10 CFR 60, subpart E-Technical Criteria $\S 60.133(f)$, requires "excavation methods that will limit the potential for creating a preferential pathway for groundwater or radioactive waste migration to the accessible 
environment." The ESF Design Requirements (DOE 1995) estimate the rock mass altered by the excavation will be within $1.5 \mathrm{~m}$ of the excavated surface.

Excavation of the NRST produced substantial overbreak on existing structural features in spite of the use of perimeter blasting procedures and in many instances violated the criteria in Table 4-1 of $<15 \mathrm{~cm}$. Perimeter holes did not generally produce idealized half-casts in the tunnel perimeter. A similar result, limited borehole half-casts, had been reported by Zimmerman et al. (1988) during controlled blasting for a mine-by experiment in fractured, welded tuffs in G-Tunnel. Maximum reported overbreak in the G-Tunnel experiment was $0.6 \mathrm{~m}(2 \mathrm{ft})$ which occurred in a faulted section.

Monitoring of the blasts indicated that reduced quantities of explosives detonated per delay and the long period between detonations were successful in controlling PPVs. Delays utilized in the blasting could be correlated with individual seismic peaks in the blasting seismic records. Comparison of near-field seismic motion from the Alcove No. 1 blasting to far-field data (see Section 3.3) indicated similar trends in PPV versus scaled distance. The near-field monitoring indicated that PPVs, with dominant frequencies below $300 \mathrm{~Hz}$, dropped below $700 \mathrm{~mm} / \mathrm{sec}(28 \mathrm{in} / \mathrm{sec})$ between $0.91 \mathrm{~m}(3 \mathrm{ft})$ and $2.44 \mathrm{~m}(8 \mathrm{ft})$ from the Alcove No. 1 perimeter. Visual observations of borehole walls at these distances indicated that motions induced on existing joint structure were sufficient to cause cracking in grout coatings along pre-existing fractures on the inside of the boreholes at $0.91 \mathrm{~m}(3 \mathrm{ft})$ but not at $2.44 \mathrm{~m}(8 \mathrm{ft})$. Rock damage was reported at PPVs above $700 \mathrm{~mm} / \mathrm{sec}(28 \mathrm{in} / \mathrm{sec})$ by Holmberg and Perrson (1979). The observations suggest that the Table 4-1 criteria of limiting measurable blast damage to within $1 \mathrm{~m}$ of the excavation perimeter may have been satisfied. 
Rev 1

All blast monitoring conducted in the NRST and Alcove No. 1 used geophones (velocity sensors) with a flat frequency response up to $300 \mathrm{~Hz}$. Recent results reported by Yang et al. (1993) indicate that near-field PPVs are substantially higher at very high frequencies $(9000 \mathrm{~Hz})$, and that geophone frequency ranges typically used for blast monitoring are not sufficiently high. They report PPVs of over $6000 \mathrm{~mm} / \mathrm{sec}(236.5 \mathrm{in} / \mathrm{sec})$ at a distance of $1 \mathrm{~m}$ and that typical charge weight scaling laws underestimated the PPV substantially at distances of less than $10 \mathrm{~m}$ ( $32.8 \mathrm{ft})$.

There has been very little data developed on the effects of frequency on intact rock damage. Dowding (1985) emphasized the importance of frequency in controlling damage to structures adjacent to blasting. Assessments of damage to underground structures were generally based on amplification factors that occurred as free-field motion intersected a tunnel. There are currently no data available on the impacts of high frequency, free-field seismic motion on the rock mass very close to the blast. However, future near-field monitoring at YMP should be based on accelerometers and recording systems that can capture the high frequency data.

\subsection{Monitoring Ground Support Systems}

The ground support installed during the construction of the NRST included rockbolts, steel lattice girders, and fibercrete. Monitoring of rockbolts was accomplished using RBLCs, as well as IRBs. In addition to monitoring within the NRST, three RBLCs were installed on rockbolts on the vertical "box-cut" face above the tunnel portal. Closure pins were attached to the lattice girders in the first $10 \mathrm{~m}(32.8 \mathrm{ft})$ to monitor displacement of this component of the ground support system. 


\subsubsection{Rockbolt Load}

RBLCs were installed in groups of three at stations along the entire NRST, and IRBs were installed on bolts within Alcove No. 1. The permanent ground support in both excavations

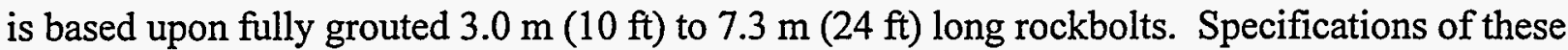
bolts are (Williams 1995):

- nominal diameter from $22.2 \mathrm{~mm}$ (7/8 in) to $28.6 \mathrm{~mm}$ (1.13 in),

- yield load from $159.9 \mathrm{kN}(36,000 \mathrm{lbs})$ to $269.9 \mathrm{kN}(60,000 \mathrm{lbs})$, and

- ultimate load from $239.9 \mathrm{kN}$ ( $54,000 \mathrm{lbs})$ to $355.9 \mathrm{kN}(80,000 \mathrm{lbs})$.

The bolts were installed by drilling the bar into the rock with a sacrificial bit, then grouting the bolt in place with a pumpable thixotropic cement grout. After grout cure, most instrumented bolts in the main tunnel were pull tested to between $111.1 \mathrm{kN}$ and $249.1 \mathrm{kN}$ to confirm the rock-grout-bolt bond.

The RBLCs were attached to the rockbolts with extension couplers and then loaded against a plate set against the tunnel perimeter by torquing up the retaining nut. These installation loads varied between $10.4 \mathrm{kN}(2335 \mathrm{lbs})$ and $42.8 \mathrm{kN}$ (9635 lbs), well below the range of bolt yield strength. All bolts underwent load bleed-off and have settled into generally stable patterns through the monitoring period (installation to June 1995). Figure 4-1 presents a graphical comparison of the installation load and final load for the monitoring period to the bolt specifications. 


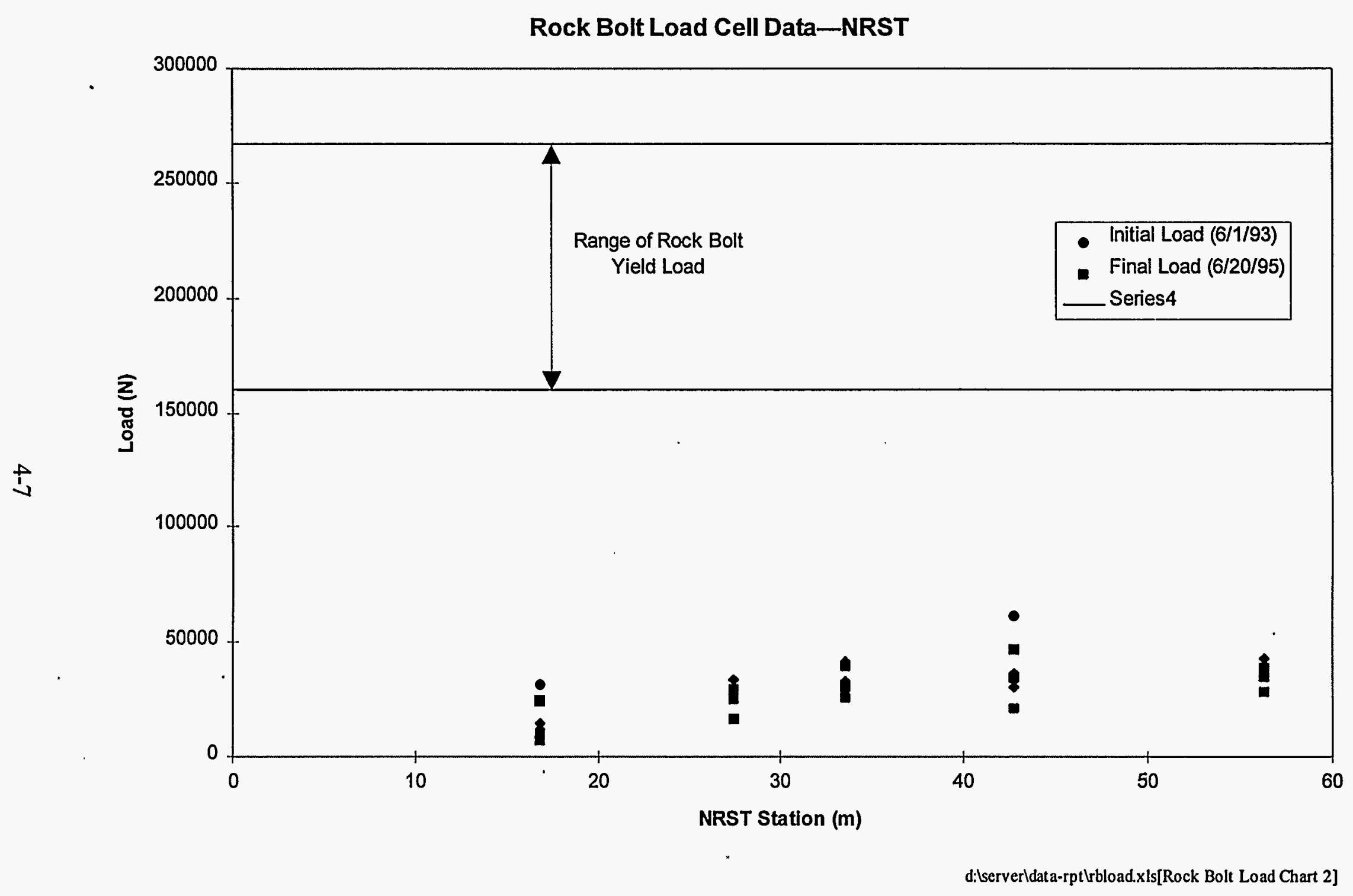

Figure 4-1. Comparison of bolt load history to bolt yield strength for different stations in the NRST. 
Rev 1

The grouted bolts were instrumented because they are the support system (in conjunction with mesh and fibercrete). Instrumentation of grouted rockbolts is generally not done because the grout column distributes bolt load into the grout/rock column by shear stress. This makes the load cell at the tunnel perimeter insensitive to loading that may occur at some depth into the rock. Bolt failure at some depth into the rock could therefore occur without the load cell seeing load changes in the range of bolt yield or ultimate strength.

This approach was modified in Alcove No. 1 by installing IRBs using conventional anchors without grouting to provide a comparison. Comparison between the IRB performance and RBLC performance indicates similar stable bolt loads with time. Figure 4-2 compares the bolt load at installation and at the end of the monitoring period to bolt yield strength for the Alcove No. 1 IRBs.

\subsubsection{Portal Girder Deformation}

Deformation of the portal girders embedded in shotcrete is tracked by the convergence data presented in Section 3.4.1.2. These deformations have apparently reached plateaus; however, they have both showed small rates of closure in the horizontal and inclined chords in the most recent measurements. These rates, $0.009 \mathrm{~mm} /$ day to $0.011 \mathrm{~mm} /$ day, are well below empirical values proposed by Bieniawski (1984) that would suggest pending instability $(0.05 \mathrm{~mm} /$ day or greater $)$. 


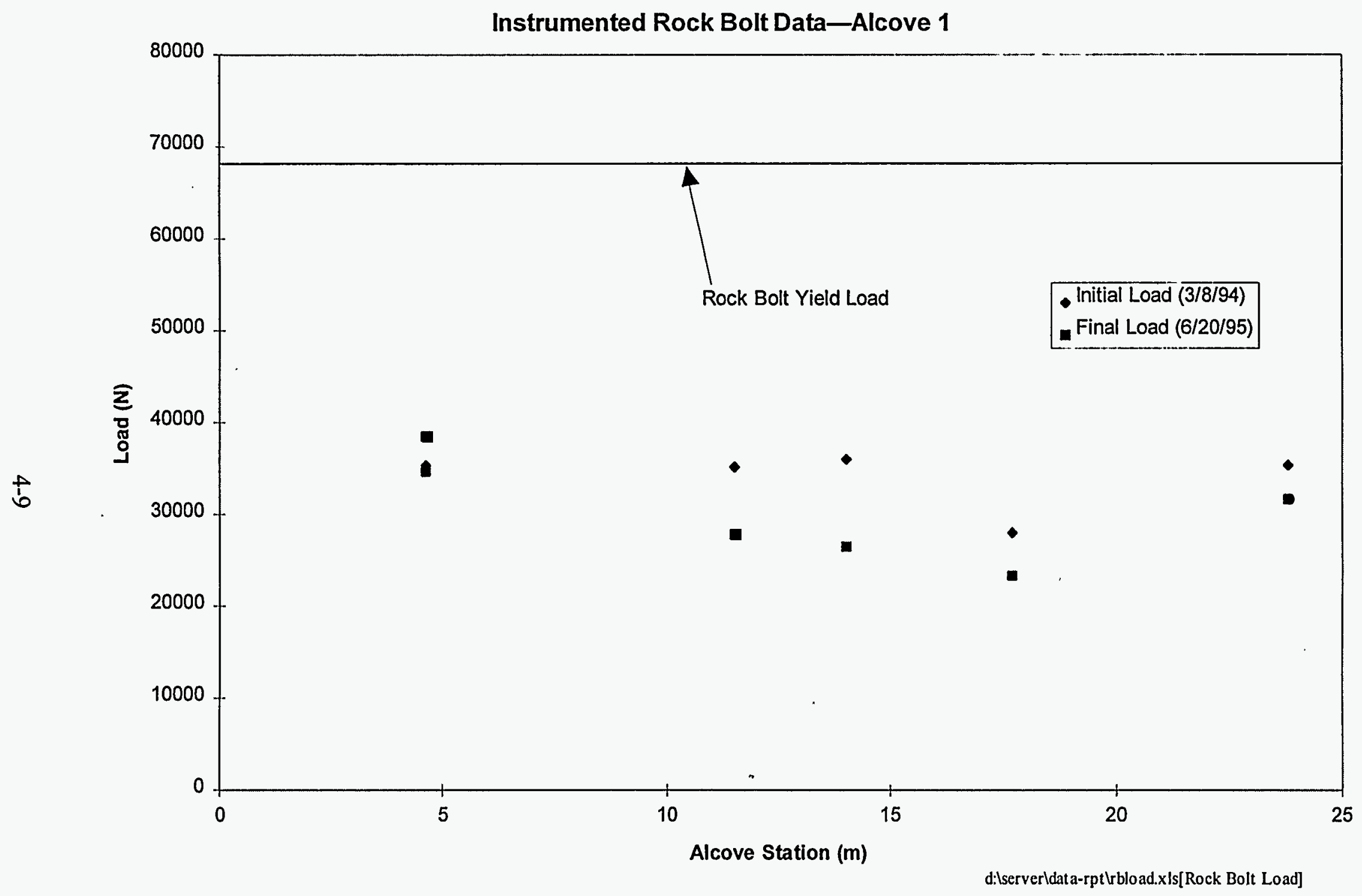

Figure 4-2. Comparison of bolt load history for IRBs in Alcove No. 1. 


\subsubsection{Visual Mapping of Fibercrete Cracking}

Some cracking has occurred in the fibercrete both on the highwall and within the NRST. This cracking was observed shortly after installation and was mapped as part of the In Situ Design Verification Study. The fibercrete in the vicinity of the cracks has been "sounded" and no evidence suggests that the fibercrete has debonded from the surrounding rock. The amount of cracking present is not considered anomalous at this time, however, the cracks will continue to be observed and compared to drift closure and RBLC data. This combined information will be used to determine whether remedial actions are required to arrest additional cracking or deterioration of the fibercrete.

\subsubsection{Verification of Ground Support Design}

Rock mass quality assessments in the NRST and Alcove No. 1 allowed empirical verification of the ground support installed in the NRST. The results of the assessments in individual sections of the excavations were presented in Section 3.2, Table 3-1, and length-weighted $\log$ mean values of $\mathrm{Q}$ were listed in Table 3-2. The range of mean values were used as the basis to assess the installed ground support using empirical design data from Barton et al. (1974).

Empirical ground support was correlated with rock mass quality $(\mathrm{Q})$ using a logarithmic scale for over 200 tunneling case histories by Barton et al. (1974). The case history data were used to develop ground support categories that were correlated with both $\mathrm{Q}$ and the excavation span divided by a factor called excavation support ratio (ESR). The ESR factor introduces an adjustment for the duty of the excavation. Temporary excavations, for example mine production 
Rev 1

excavations, have a large ESR (3-5). Underground civilian facilities, major highway tunnels, portals, power stations, etc. have an ESR of 1.0. YMP has adopted an ESR value of 1.0 for most of the ESF openings. ${ }^{1}$

The empirical ground support as described by Barton et al. (1974) is compared to installed ground support in Table 4-2. The table indicates that the installed ground support is consistent with the empirical ground support design approach in all areas of the NRST.

All data collected to monitor ground support performance for the NRST and Alcove No. 1 suggest that the installed ground support is performing within design specifications. Continued monitoring of all ground support instrumentation is required so that any deterioration in ground support performance is recorded and appropriate remedial measures taken.

\subsection{Monitoring Drift Stability}

Drift stability in the NRST was monitored by making displacement measurements in the rock mass using extensometers and by measuring overall closure using tape extensometers. These measurements have been compared with both empirical criteria and the tentative SCP goals in Table 4-1 to ascertain whether the drifts are performing according to design requirements. Performance requirements for underground structures are generally linked to their functional requirements. The ESF accesses require greater control of potential instabilities to assure that they are not manifested as deleterious rock movement and to allow continuity of function during the site characterization.

'ESF Ground Support Design Analysis, BABEE0000-01717-0200-00002, Rev. 00D. 

Support

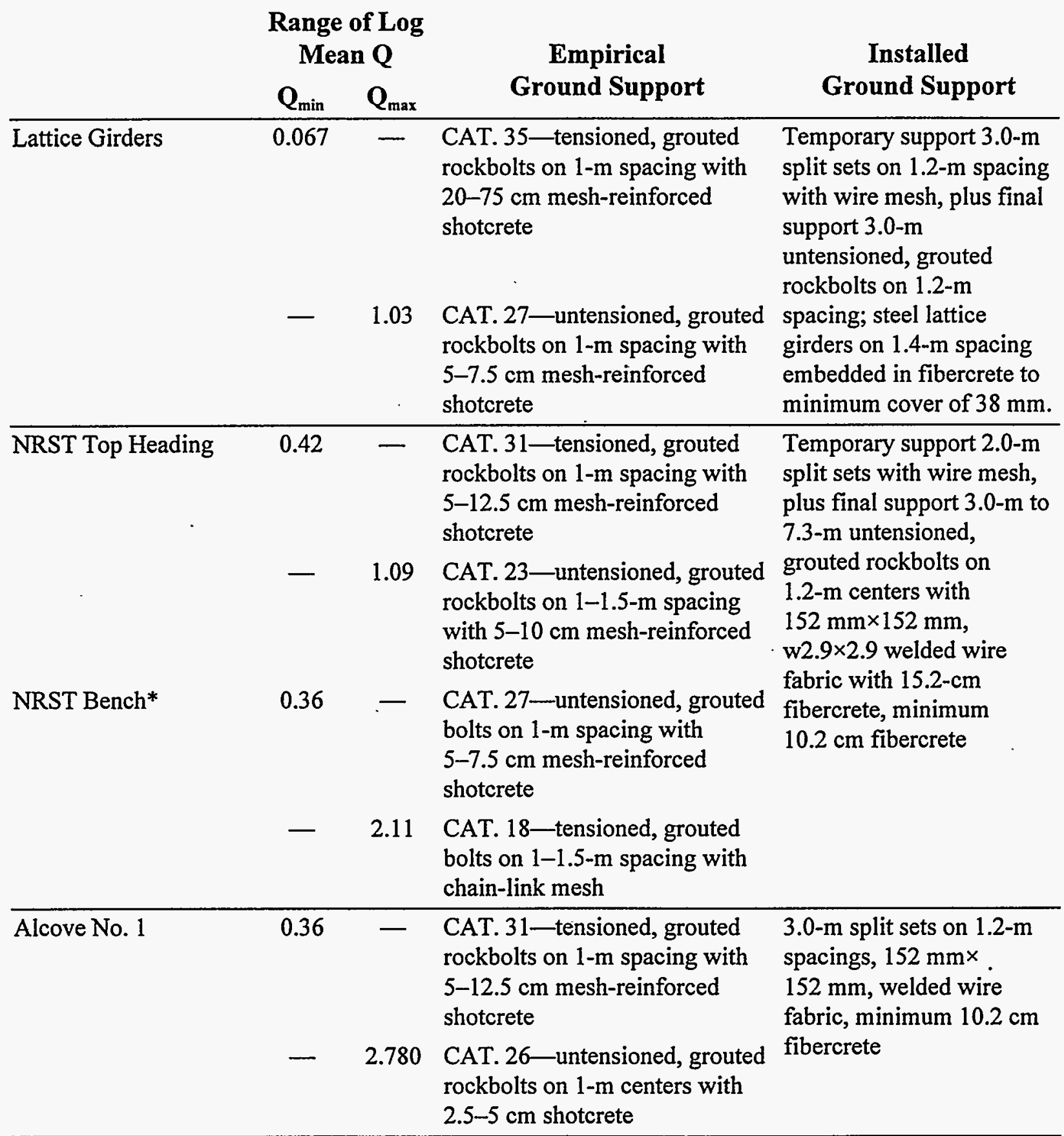

${ }^{*} \mathrm{Q}$ is multiplied by 2.5 , as per Barton et al. (1974), to determine wall support category. 
Empirical criteria relating measured displacements to underground opening stability were described by Bieniawski (1984):

- rates of displacement of the order of $0.001 \mathrm{~mm} /$ day $(0.0004 \mathrm{in} /$ day $)$ indicate stable conditions,

- rates of $0.05 \mathrm{~mm} /$ day ( $0.002 \mathrm{in} /$ day) are quite high and dangerous for wide chambers, and

- rates of over $1.0 \mathrm{~mm} /$ day ( $0.039 \mathrm{in} /$ day $)$ are excessive and call for additional support measures.

These criteria compare well with the tentative goal in Table $4-1$ of rates less than $1 \mathrm{~mm} / \mathrm{yr}$ ( $0.039 \mathrm{in} / \mathrm{yr})$ or an average rate of $0.0027 \mathrm{~mm} /$ day $(0.0004 \mathrm{in} /$ day $)$.

Displacement rate data from the monitoring records in Section 3.0 have been summarized and presented graphically in Figure 4-3 for comparison against the empirical criteria. The figure presents displacement rates from both convergence and extensometer measurements as a function of tunnel station and indicates that rates at the end of June 1995 are well below the empirical criteria of $0.05 \mathrm{~mm} /$ day $(0.002 \mathrm{in} /$ day $)$ for wide openings. The NRST width of $10 \mathrm{~m}(32.8 \mathrm{ft})$ would be considered at the lower end of the range of wide openings. However, the rates are generally higher than the SCP tentative yearly goal which would produce an average daily closure rate of $0.0027 \mathrm{~mm} /$ day $(0.0004 \mathrm{in} /$ day $)$. The low displacement rates were confirmed by RBLC records which indicated generally stable trends in bolt load change.

Alcove No. 1 convergence and extensometer data indicated generally expansive convergence deformations at the end of the monitoring period (June 1995). The maximum closure rate was $0.004 \mathrm{~mm} /$ day $(0.0002 \mathrm{in} /$ day $)$, well below the rate at which concern for stability would be indicated. These results are consistent with expected drift stability for an opening at shallow depth. 
Rev 1

\section{Comparison of NRST Closure Rates to Stability Criteria}

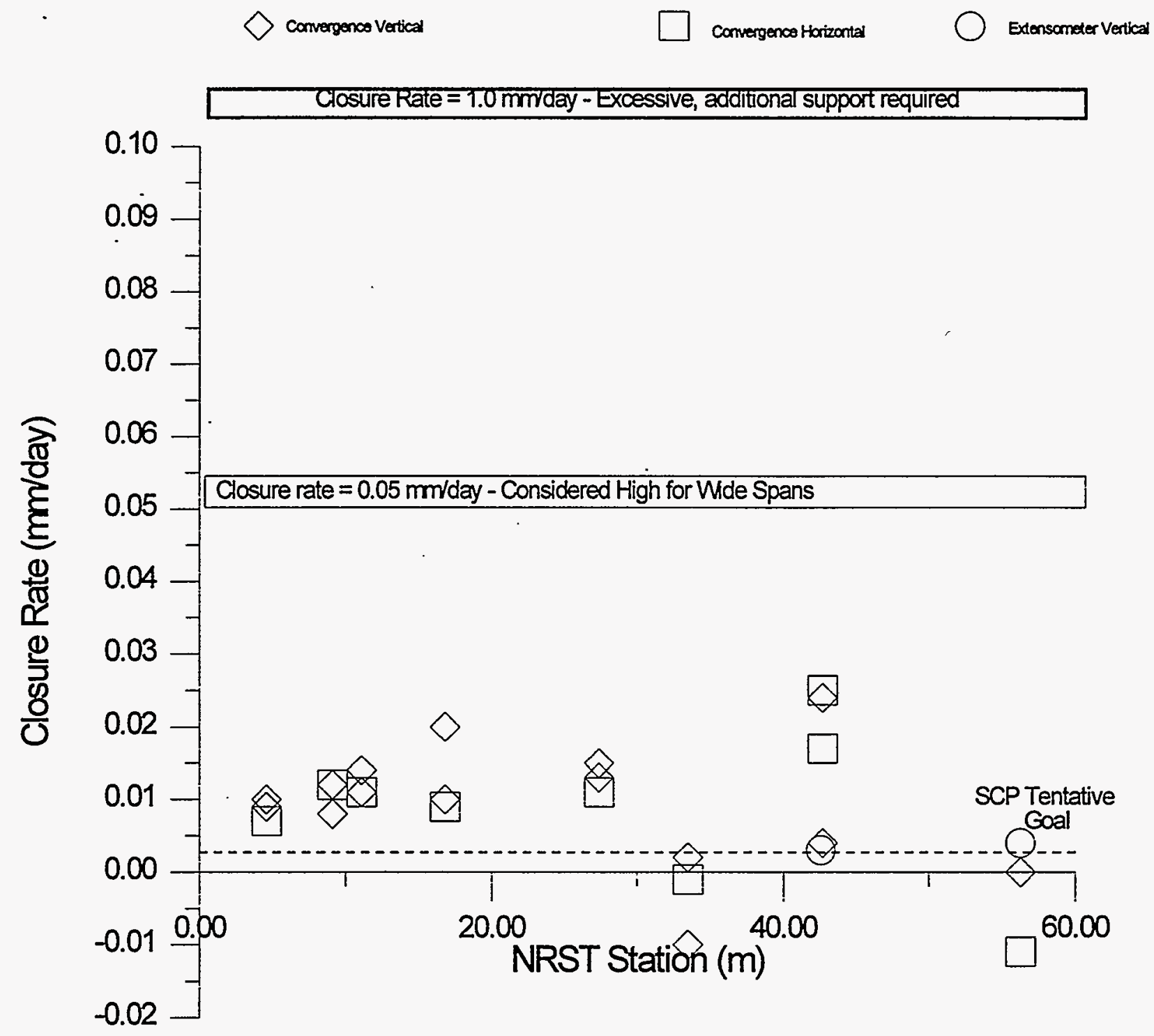

Figure 4-3. Comparison of NRST closure rates to stability criteria. 


\subsection{Summary and Conclusions}

Sandia National Laboratories is conducting ongoing in situ experiments and activities to support design verification of the underground openings for the proposed repository at Yucca Mountain. This report describes these experiments and activities conducted in the North Ramp Starter Tunnel and Alcove No. 1, including evaluation of the mining methods, evaluation of drift stability, and evaluation of ground supports. The measurements in and around the NRST are expected to continue throughout the life of the proposed repository. Therefore, the data presented in this report, April 1993 through June 1995, represent the first of a series of reports covering the design verification activities.

Installed instrumentation included rockbolt load cells, instrumented rockbolts, borehole extensometers, closure pins, and borehole pressure cells. In general, the instrumentation has performed well with the exception of the borehole pressure cells and have provided continuous data since installation. The borehole pressure cells showed excessive pressure bleed-off at low installation pressures ( $<2 \mathrm{MPa}, 290 \mathrm{psi})$ and had large daily temperature effects even after efforts to insulate the exposed transducers. BHPC performance may have been impacted by the relatively poor rock quality and high rates of air movement through the rock that may have caused convective temperature changes around the BHPCs.

Blasting seismic monitoring was conducted during excavation and rock mass quality was assessed for various intervals as they were excavated.

Evaluation of the data indicated the following main conclusions: 


\section{Rev 1}

- The range of rock mass quality data collected in the NRST was large $(Q=0.06-17.40)$ and indicated generally poor rock conditions.

- The installed ground support was consistent with ground support requirements indicated by the rock mass quality (Q) and empirical case history data reported by Barton et al. (1974).

- The performance of the instrumented ground support components, rockbolts, and lattice girders indicated that they are not currently being loaded excessively by ongoing tunnel deformation.

- The magnitude of closure measured in the tunnel after installation of the final ground support has been relatively small. The maximum closure was less than $12 \mathrm{~mm}(0.47 \mathrm{in})$ along horizontal chords. Maximum closure measured on inclined roof-to-floor chords was less than $2 \mathrm{~mm}(0.08 \mathrm{in})$

- Closure curves have generally reached plateau values since mid-1994. Since this time, displacement rates indicate both expansion and closure. This behavior is consistent with oscillations around a stable value due to long period thermal response because of the near-surface proximity.

- Closure rates, as measured by convergence points, at the end of the monitoring period, are relatively low by empirical tunneling criteria $(<0.02 \mathrm{~mm} /$ day, $0.0008 \mathrm{in} /$ day $)$, but are greater than the SCP tentative goal for average daily convergence of accesses of $0.0027 \mathrm{~mm} / \mathrm{day}$ ( $0.0004 \mathrm{in} /$ day). However, the rates reported are the most recent values taken from the end of the monitoring period and may represent cyclic thermal displacements, not continued long-term trends. Closure rates, as measured by vertical MPBXs where data points are collected daily, were less than $0.004 \mathrm{~mm} /$ day (0.00016 in/day). 
- Blasting monitoring data suggested that peak particle velocities produced by the controlled blasting procedures were consistent with good practice. The rock damage assessment performed suggested that the rock damage may have been consistent with tentative SCP goals.

- The results of monitoring instruments in the NRST indicate overall performance of the NRST that is consistent with the SCP goals for both long-term stability and the functional requirements. 
This page left intentionally blank. 


\subsection{References}

Barton, N.R., R. Lien, and J. Lunde (1974). Engineering Classification of Rock Masses for the Design of Tunnel Support, Rock Mechanics, 6:189-236, Springer Verlag. (NNA.8700406.0237)

Bieniawski, Z.T. (1979). Engineering Rock Mass Classification, Wiley-Interscience Publication, John Wiley \& Sons, New York, New York. (NNA.901005.0044)

Bieniawski, Z.T. (1984). Rock Mechanics Design in Mining and Tunneling, A.A. Balkema, Boston.

Brechtel, C.E., M. Lin, E.R. Martin, D.S. Kessel (1995). Geotechnical Characterization of the North Ramp of the Exploratory Studies Facility, SAND95-0488/1, Yucca Mountain Site Characterization Project, Sandia National Laboratories, Albuquerque, New Mexico. (MOL.19950502.0004)

Caceci, M.S., and W.P. Cacheris (1984). Fitting Curves of Data, Byte, May, pp. 340-362.

Department of Energy (DOE) (1988). Site Characterization Plan, Yucca Mountain Site, Nevada Research and Development Area, Nevada, DOE/RW-0199, Chapter 8. (HQ0.881201.0002).

Department of Energy (DOE) (1991). Yucca Mountain Site Characterization Project, Study Plan No. 8.3.1.14.2, Studies to Provide Soil and Rock Properties of Potential Locations of Surface and Subsurface Access Facilities, U.S. Geological Survey, November. (NNA.911108.0238) 
Department of Energy (DOE) (1995). Yucca Mountain Site Characterization Project, Exploration Studies Facility Design Requirements, Vol. 1, Rev. 1//CN-2, YMP/CM-0019.

Dowding, C.H. (1985). Blast Vibration Monitoring and Control, Prentice Hall, Englewood Cliff, New Jersey.

Dupont (1980). Blasters Handbook, 16th Edition, Wilmington, Delaware.

Hardy, M.P., and S.J. Bauer, 1991. Drift Design Methodology and Preliminary Application for the Yucca Mountain Site Characterization Project, SAND89-0837, Sandia National Laboratories, Albuquerque, New Mexico. (NNA.910808.0105)

Holmberg, R., and P. Persson (1979). Design of Tunnel Perimeter Blasthole Patterns to Prevent Rock Damage, Tunneling 79, Institute of Mining and Metallurgy, London, pp. 280-283. Hudson, J.A., and S.D. Priest (1979). Discontinuities and Rock Mass Geometry, International Journal of Rock Mechanics, Mining Sciences and Geomechanics Abstracts, Pergamon Press, 16(6):339-362. (NNA.900403.0399)

TRW Environmental Safety Systems, Inc. (1995). Repository Design Data Needs, BC0000000-01717-5705-00012, Rev. 00, Civilian Radioactive Waste Management System, Management and Operations Contractor.

Williams Form Engineering Corp. (1995). Rock Anchor Systems, No. 392, product literature, Williams Form Engineering Corp., Grand Rapids, Michigan.

Yang, R., W.F. Bawden, S. Talebi, and P. Rocque (1993). An Integrated Technique for Vibration Monitoring Adjacent to a Blast Hole, Canadian Institute of Mining (CIM) Bulletin, July-Aug, CIM 86(972):45-52. 
Rev 1

Zimmerman, R.M., R.A. Bellman, Jr., K.L. Mann, D.P. Zerga, M. Fowler, and R.L. Johnson

(1988). G-Tunnel Welded Tuff Mining Experiment Evaluations, SAND87-1433, Yucca

Mountain Project, Sandia National Laboratories, Albuquerque, New Mexico. 
This page left intentionally blank. 
Rev 1

\section{Appendix A \\ Traceability of NRST Data}

Data in this report were developed and documented in a series of scientific notebooks. The relationship of the notebook and traceability of the data into this report "Evaluation of Geotechnical Monitoring Data from the ESF North Ramp Starter Tunnel April 1994 to June 1995" are described in Figure A-1. The figure presents a flowchart showing the activities of data collection and linkage between scientific notebooks which are listed by their number (SN \#04, for example) and the notebook title. A central analysis file was developed to support preparation of the report and all relevant information from the scientific notebooks was assembled in this file. The data were submitted in the following interim data transmittals:

1. DTN: SNF32120393001.010—RBLC, IRB, and MPBX Data for the NRST/Alcove No. 1 (initial installation through June 20, 1995)

2. DTN: SNF33120393002.001-Convergence Pin Data for the NRST/Alcove No. 1 (initial installation through July 2, 1995)

3. DTN: SNF28021693001.005—Rock Mass Quality Assessments in the North Ramp Starter Tunnel-Top Heading, Bench, and Alcove No. 1

4. DTN: SNF28021693001.006-Map of Fibrecrete Surface Cracks—North Ramp Starter Tunnel

5. DTN: SNF28021693001.007-Blast Monitoring Data-North Ramp Starter Tunnel, Top Heading and Alcove No. 1

6. DTN: SNF28021693001.008—North Ramp Starter Tunnel, Borehole Pressure Cell Data Collected during TBM Mine-By 


\section{Traceability of Data for the North Ramp Starter Tunnel Data Report}

Sandia National Laboratories YMP WA-0065, Rev 3 and WA-011.6, Rev 1

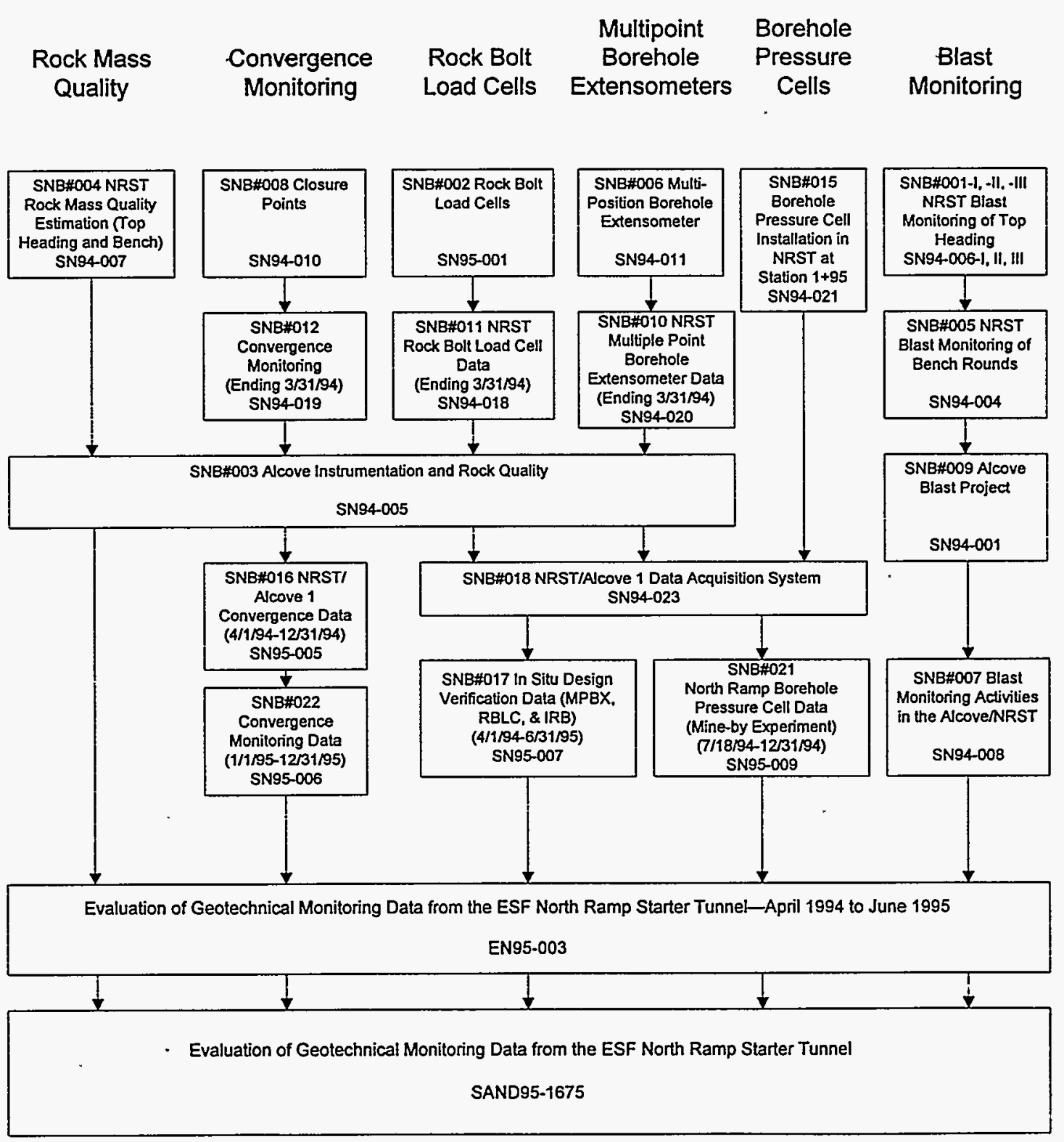

Figure A-1. Flow chart showing data collection activities and traceability of data in scientific notebooks. 


\section{Appendix B}

NRST Plan Map with Instrument Locations 


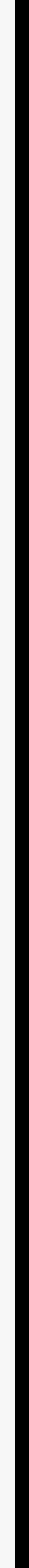




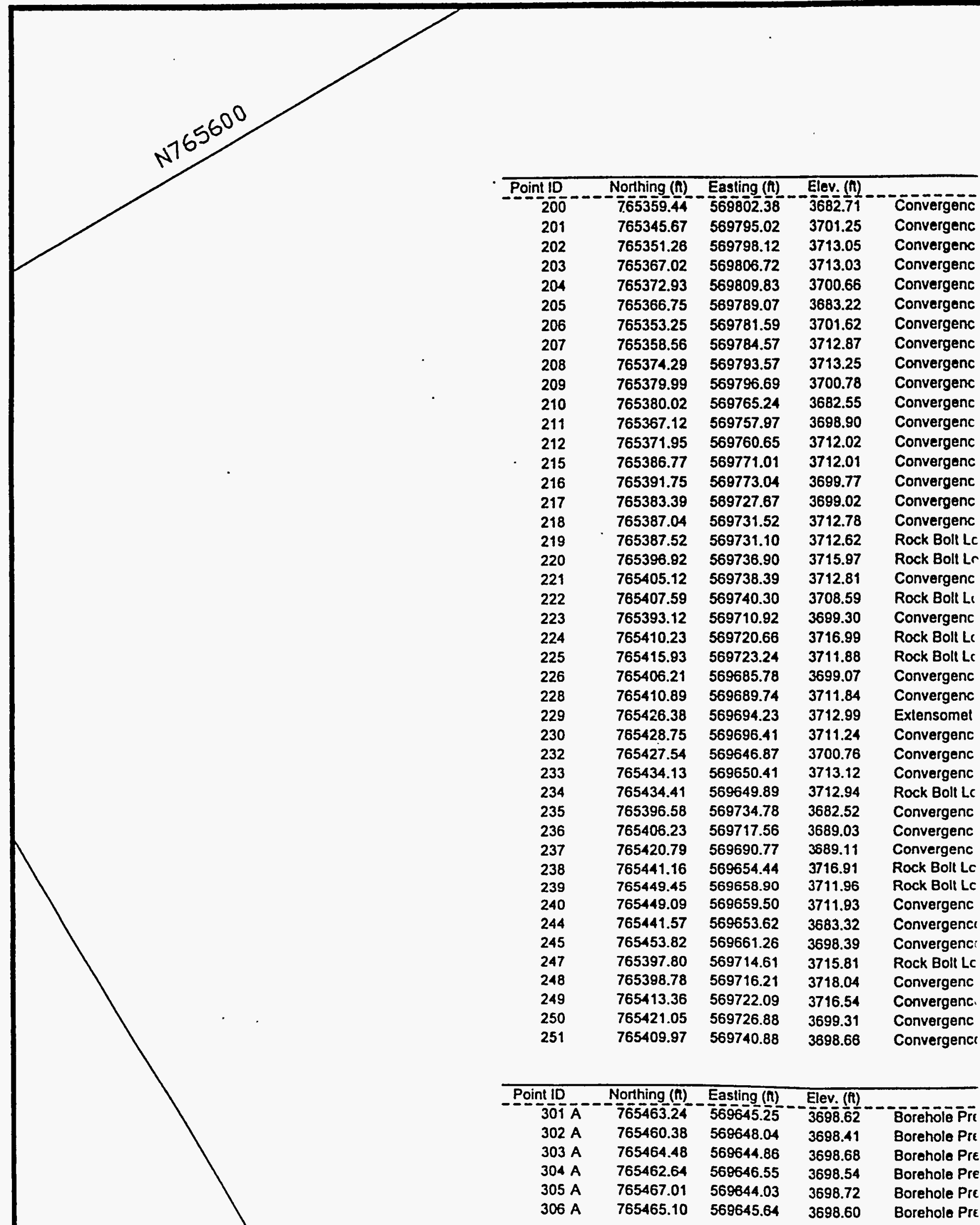


Elev. (n)

3713.05

3713.03

3700,66

3883.22

3701.62

3712,87

3713.25

3700.78

3682.55

3608.90

3712.02

3712.01

3690.77

3689.02

3712.78

3712.62

3715.97

3712.81

3708.59

3698.30

3716.98

3711.88

3699.07

3711.84

3712.89

3711.24

3700.76

3713.12

3712.94

3682.52

3689,03

3689.11

3716.91

3711.96

3711.83

3683.32

3698.39

3715.81

3718.04

3698.31

3688.66
3716.54

Descriplor

Convergence $\overline{p i n} 0+04 . \bar{F}$

Convergence Pin 0+04.6 SLL

Convergence Pin 0+04.6 UL.

Convergence Pin 0+04.6 UR

Convergence Pin 0+04.6 SLR

Convergence Pin 0+09.1 F

Convergence Pin 0+09.1 SLL

Convergence $P$ in $0+09.1 \mathrm{UL}$

Convergence Pin 0+09.1 UR

Convergence Pin 0+09.1 SLR

Convergence $\mathrm{Pin} 0+16.8 \mathrm{~F}$

Convergence Pin 0+16.8 SLL.

Convergence Pin 0+16.8 UL

Convergence Pin 0+16.8 UR

Convergence Pin $0+16.8$ SLR

Convergence Pin $0+27.4$ SLL

Convergence Pin $0+27.4$ UL

Rock Bolt Load Cell 0+27.4 L

Rock Boll Load Cell 0+27.4 C

Convergence Pin 0+27.4 UR

Rock Boll Load Cell 0+27.4R

Convergence Pin 0+33.5 SLL

Rock Boll Load Cell 0+33.5 C

Rock Bolt Load Cell 0+33.5 R

Convergence Pin 0+42.7 SLL

Convergence Pin 0+42.7 UL

Extensometer (MPBX) $0+42.7 \mathrm{~V}$

Convergence Pin 0+42.7 UR

Convergence Pin 0+56.3 SLL

Convergence $\mathrm{Pin} 0+56.3 \mathrm{UL}$

Rock Bolt Load Cell 0+56.3 L

Convergence Pin 0+27.4 F

Convergence $\mathrm{Pin} 0+33.5 \mathrm{~F}$

Convergence Pin $0+42.7 \mathrm{~F}$

Rock Bolt Load Cell 0+56.3 C

Rock Boll Load Cell 0+56.3 R

Convergence Pin $0+56.3$ UR

Convergence $P$ in $0+56.3 \mathrm{~F}$

Convergence Pin 0+56.3 SLR

Rock Boll Load Cell 0+33.5 L

Convergence Pin 0+33.5 UL

Convergence Pin $0+33.5$ UR

Convergence Pin $0+33.5$ SLR .

Convergence Pin 0+27.4 SLR

\section{Elev, (fi) _ _.}

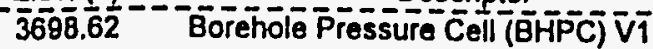

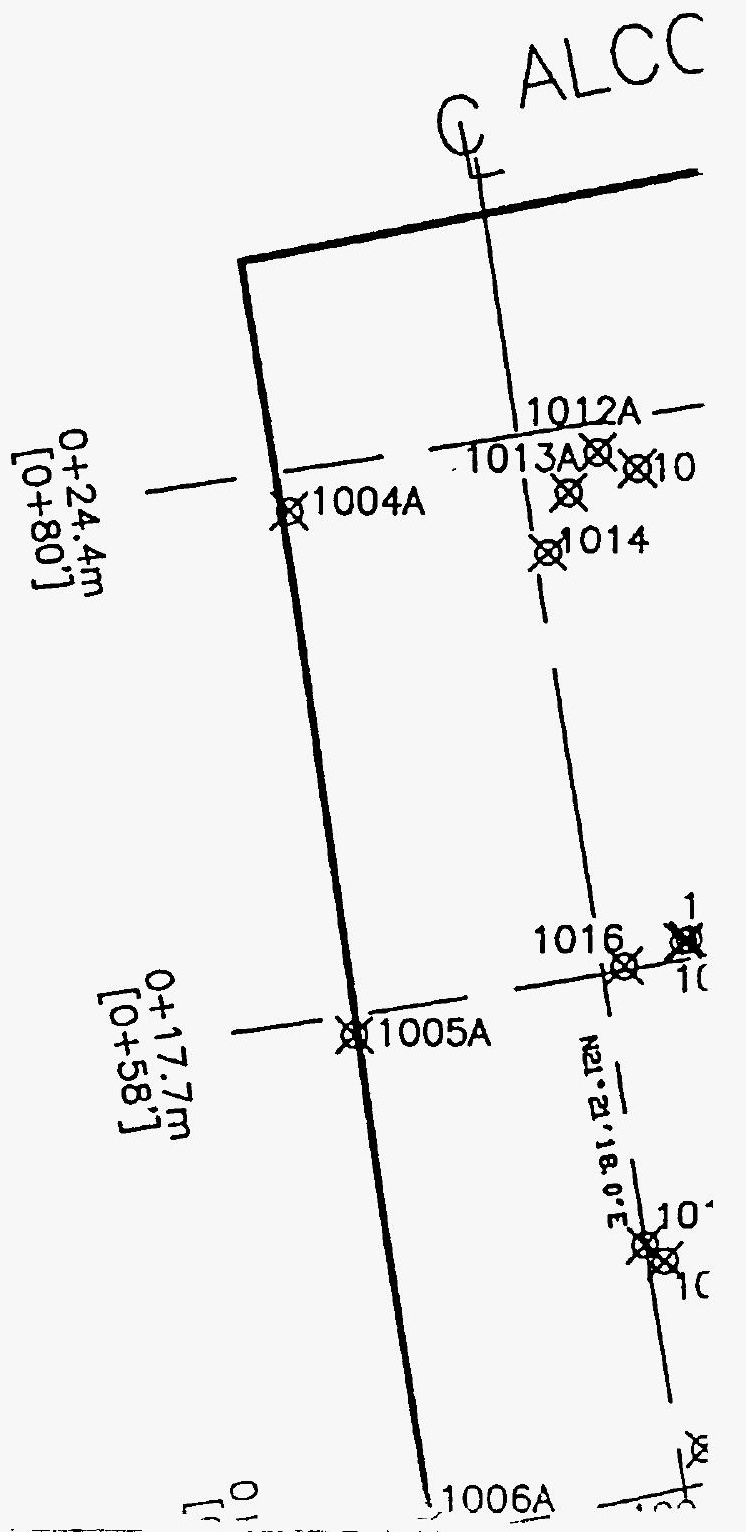




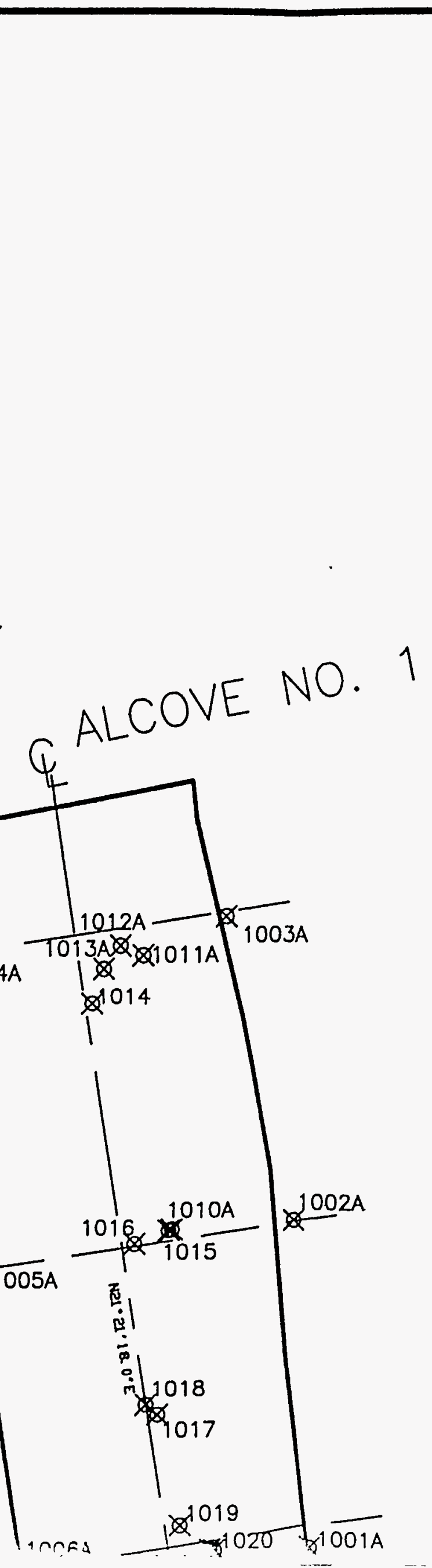




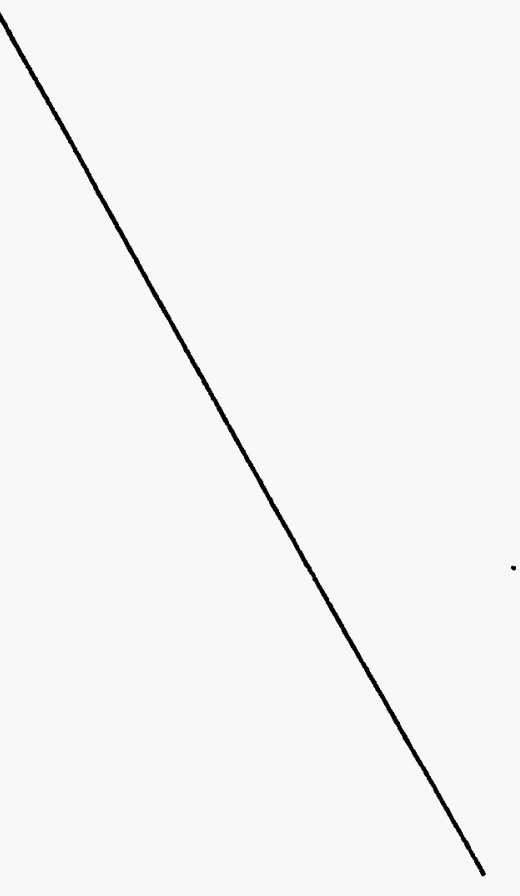

\begin{tabular}{|c|c|c|c|}
\hline$=\frac{1}{1000} \bar{A}-$ & $\begin{array}{l}\text { Northing (fi) } \\
\overline{7} \overline{6} 54 \overline{3} 2.79\end{array}$ & Easting (n) & $\begin{array}{l}\text { Elev. }(n) \\
-3682.32\end{array}$ \\
\hline $1001 \mathrm{~A}$ & 765450.01 & 569713.84 & 3693.01 \\
\hline $1002 \mathrm{~A}$ & 765470.21 & 569724.23 & 3892.42 \\
\hline $1003 \mathrm{~A}$ & 765490.89 & 568730.75 & 3893.84 \\
\hline $1004 \mathrm{~A}$ & 765497.03 & 568711.59 & 3693.12 \\
\hline $1005 \mathrm{~A}$ & 765477.52 & 568703.20 & 3692.89 \\
\hline $1006 \mathrm{~A}$ & 765458.06 & 569695.61 & 3692.85 \\
\hline $1007 \mathrm{~A}$ & 765440.66 & 569688.89 & 3693.07 \\
\hline $1008 \mathrm{~A}$ & 765434.86 & 569699.86 & 3683.86 \\
\hline $1008 \mathrm{~A}$ & 765453.41 & 569707.75 & 3684.51 \\
\hline $1010 \mathrm{~A}$ & 765474.00 & 569716.41 & 3684.37 \\
\hline $1011 \mathrm{~A}$ & 765491.45 & 569724.50 & 3685.02 \\
\hline $1012 \mathrm{~A}$ & 765482.81 & 569723.46 & 3702.94 \\
\hline $1013 \mathrm{~A}$ & 765482.02 & 569721.66 & 3703.31 \\
\hline 1014 & 765490.35 & 569719.75 & 3703.49 \\
\hline 1015 & 765473.84 & 569716.64 & 3701.56 \\
\hline 1018 & 765474.37 & 569713.90 & 3702.21 \\
\hline 1017 & 765463.30 & 569709.35 & 3702.53 \\
\hline 1018 & 765464.31 & 589709.00 & 3702.67 \\
\hline 1019 & 765455.88 & 569706.83 & 3702.64 \\
\hline 1020 & 765453.22 & 569707.89 & 3701.85 \\
\hline 1021 & 765452.26 & 568704.15 & 3701.58 \\
\hline 1022 & 765434.86 & 569698.84 & 3702.33 \\
\hline 1023 & 765433.57 & 589704.83 & 3899.42 \\
\hline 1024 & 765435.45 & 569898.76 & 3702.09 \\
\hline
\end{tabular}

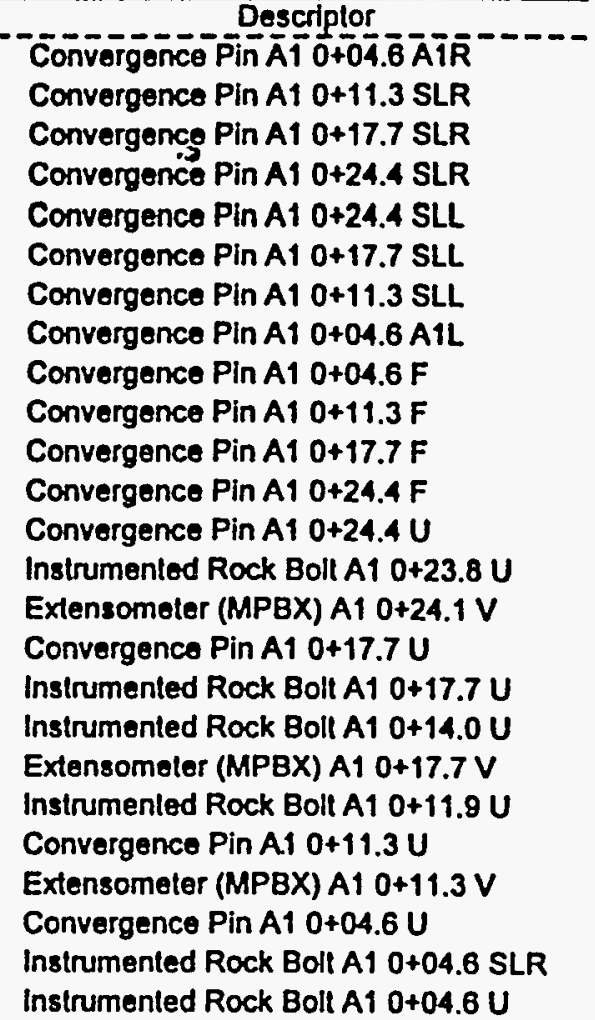

\begin{tabular}{|c|c|c|c|c|}
\hline Point 10 & 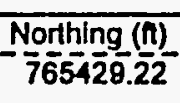 & Easting (it) & Elev. $\frac{(\pi)}{3687.37}$ & Extensomeler (MPBX) \\
\hline Point 10 & Northing (fi) & Easting $(n)$ & 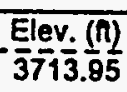 & Extensometer (Mescriplor \\
\hline $1001 \mathrm{~B}$ & 765408.81 & 588687.53 & 3707.41 & Rock Bolt Load Cell 0+42.7 L \\
\hline $1002 \mathrm{~B}$ & 765418.72 & 568692.55 & 3714.52 & Rock Boll Load Cell 0+42.7 C \\
\hline 10038 & 765428.02 & 569697.14 & 3711.24 & Rock Bolt Load Cell 0+42.7 R \\
\hline $1004 \mathrm{~B}$ & 765388.28 & 568770.71 & 3711.43 & Rock Bolt Load Cell 0+16.6 R \\
\hline $1005 \mathrm{~B}$ & 765374.40 & 569781.89 & 3714.19 & Rock Boll Load Cell 0+16.8 L \\
\hline $1006 \mathrm{~B}$ & 765379.15 & 569767.88 & 3715.38 & Rock Bolt Load Cell 0+16.8 C \\
\hline $1007 \mathrm{~B}$ & 765345.91 & 569806.63 & 3727.83 & Rock Bolt Load Cell 0+00.0 L \\
\hline $1008 \mathrm{~B}$ & 765357.53 & 569806.93 & 3731.13 & Rock Bolt Load Cell 0+00.0 C \\
\hline $1009 \mathrm{~B}$ & 765364.06 & 568816.42 & 3722.05 & Rock Boll Load Cell 0+00.0 R \\
\hline $1010 \mathrm{~B}$ & 765369.69 & 569783.27 & 3683.46 & Convergence $P$ in $0+10.7 F$ \\
\hline $1011 \mathrm{~B}$ & 765373.11 & 569786.58 & 3715.76 & Convergence Pin $0+10.7$ UR \\
\hline $1012 \mathrm{~B}$ & 765356.87 & 568774.39 & 3708.10 & Convergence Pin $0+10.7 \mathrm{SLL}$ \\
\hline $1013 \mathrm{~B}$ & 765363.22 & 569779.87 & 3715.88 & Convergence Pin 0+10.7 UL \\
\hline
\end{tabular}

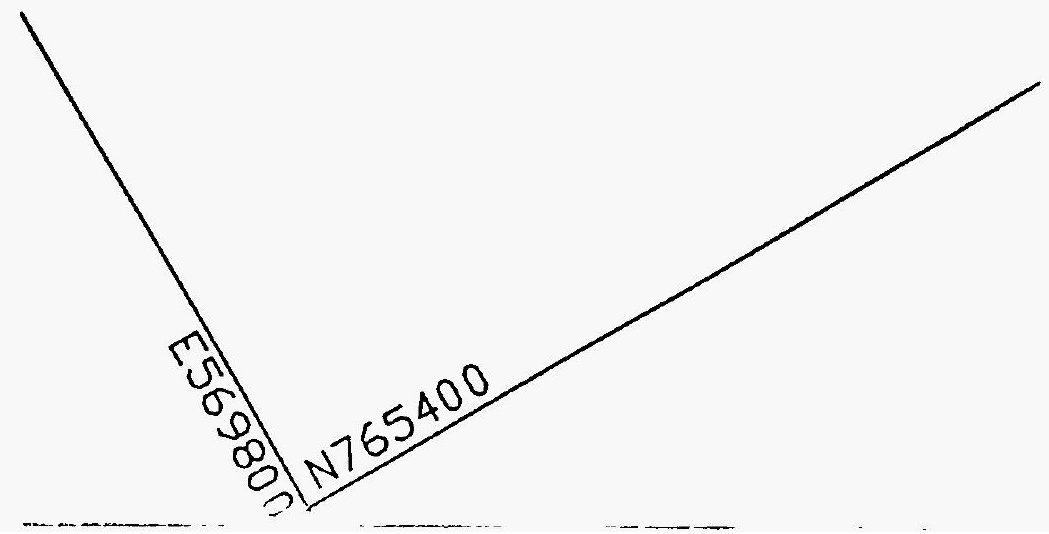



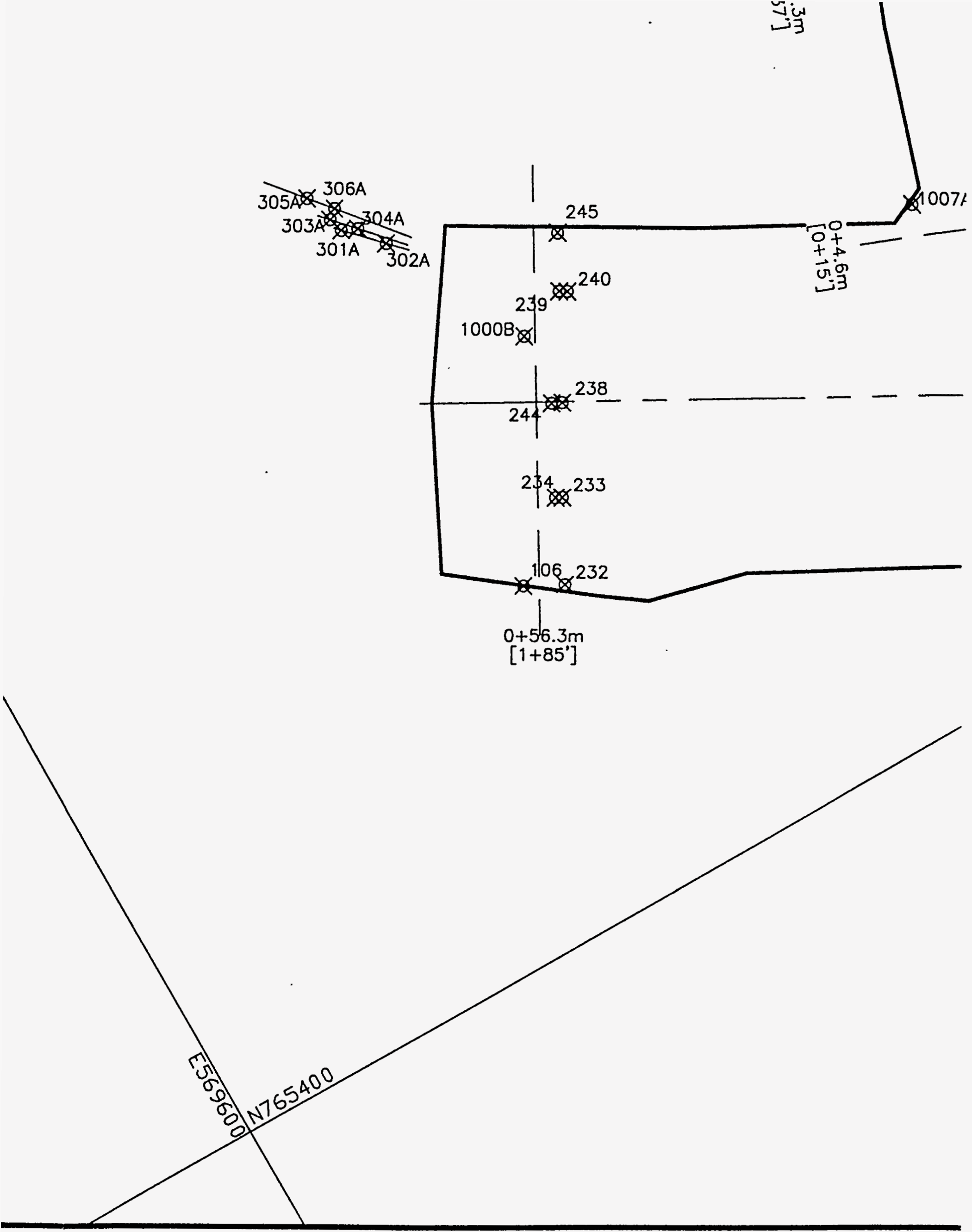


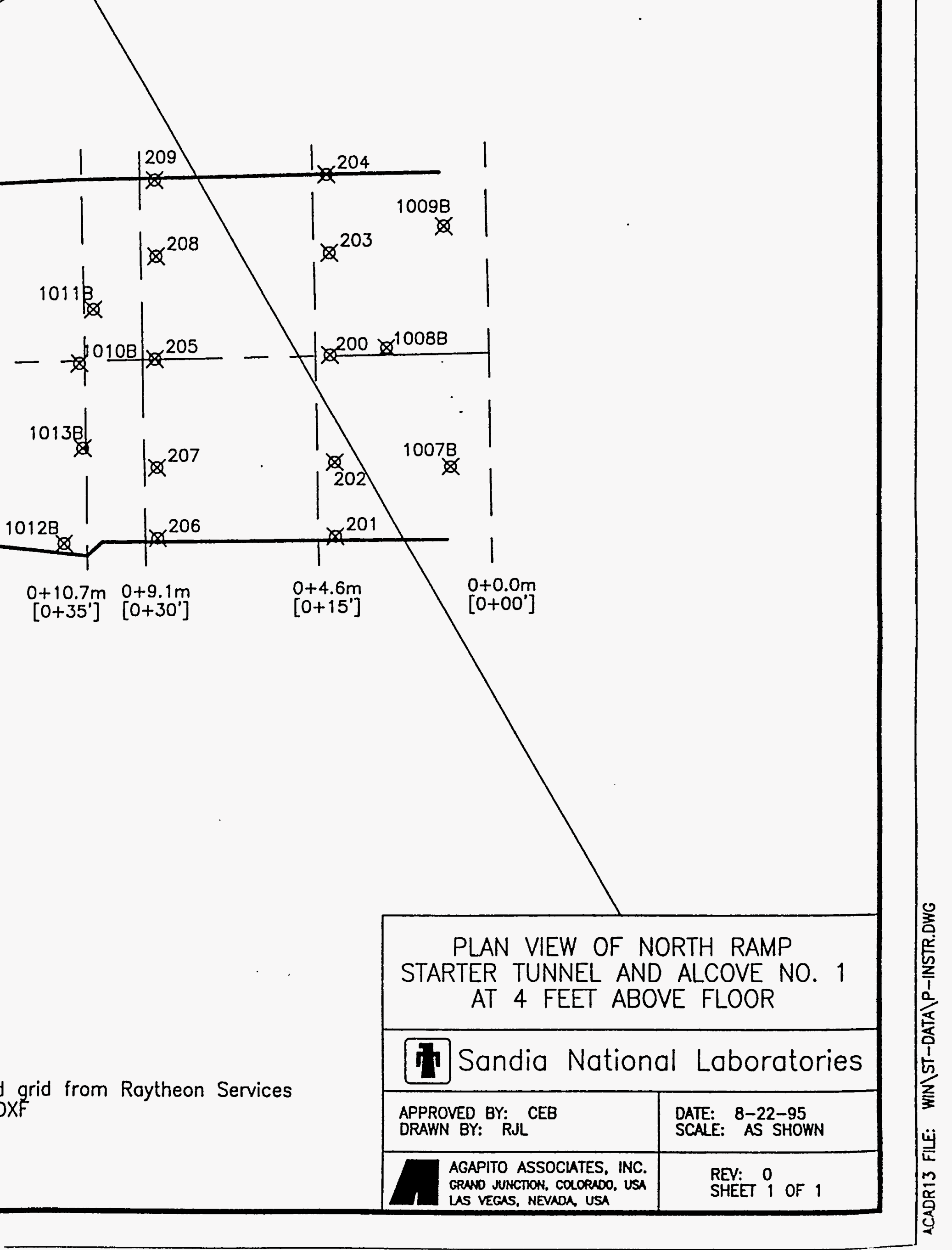


Rev 1

\section{Appendix C \\ NRST Instrument Stations and \\ Data Acquisition System}



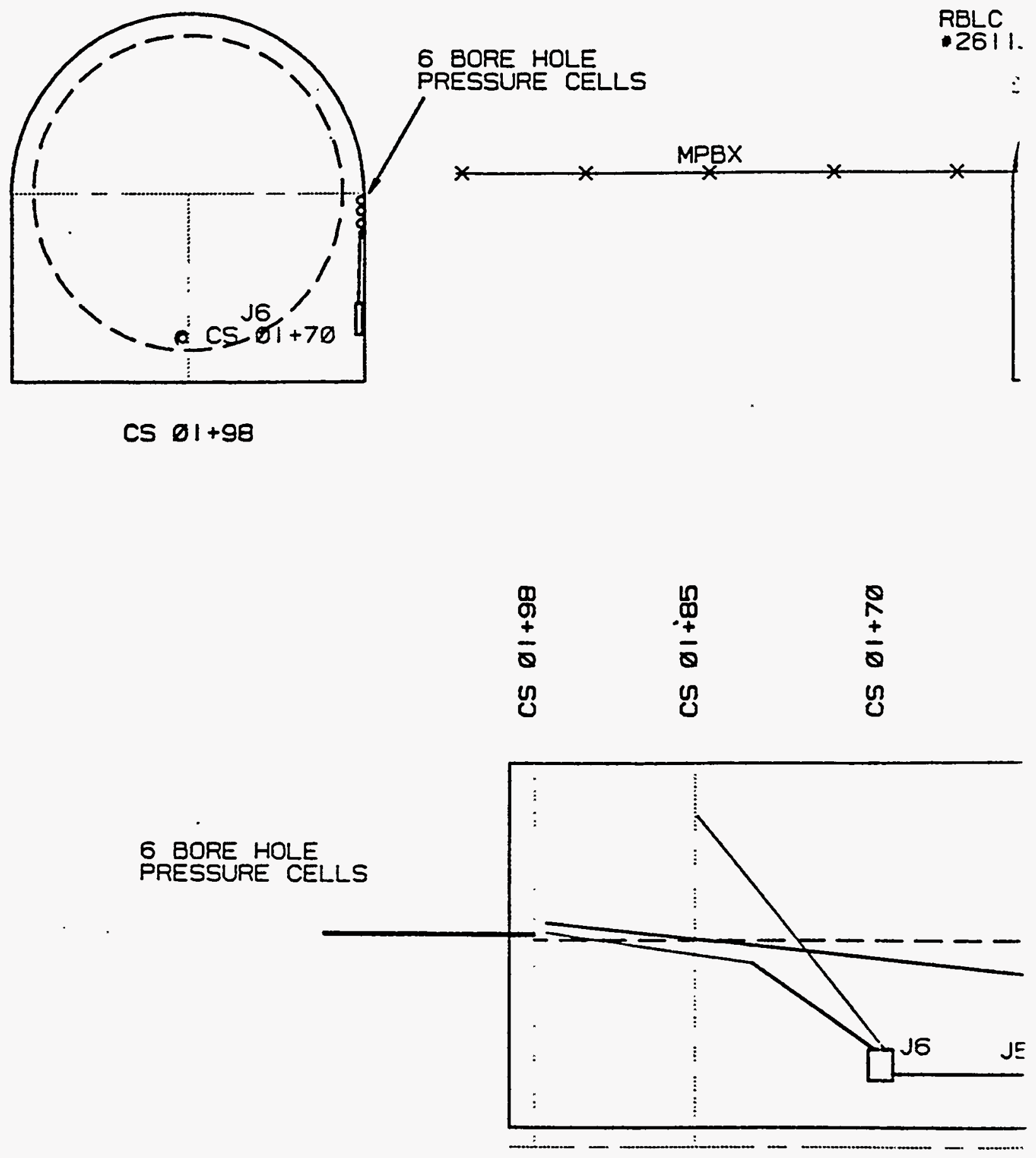

ALCOVE

TEST ALCOVE MEASUREMENTS

DATA 6 RBLC.

$\begin{array}{ll}4 & 1 \text { MPBX (2 POINT) } \\ & 2 \text { MPBX (SINGLE POINT) }\end{array}$

POWER

1 4PLEX

110 VAC 20A

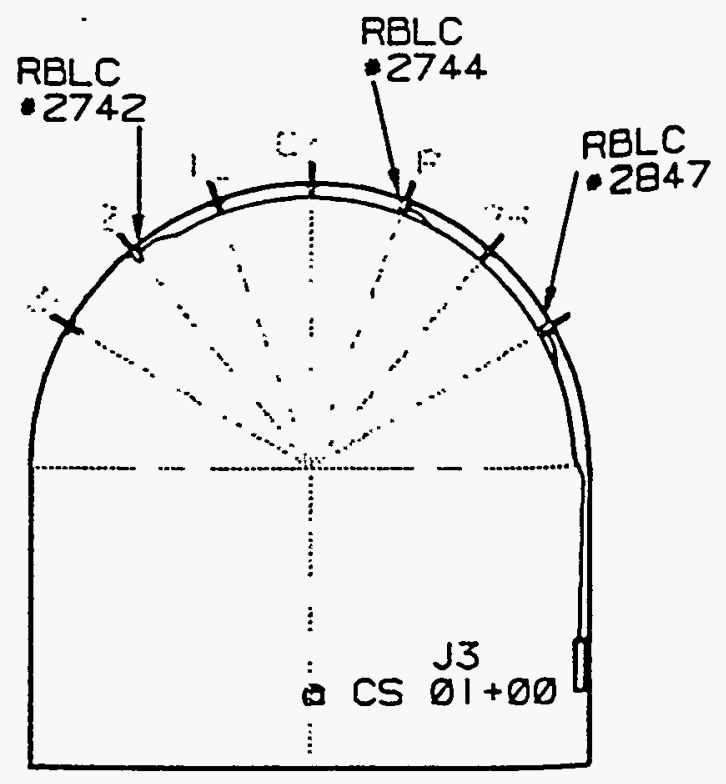

CS $01+10$ R2 $\theta$
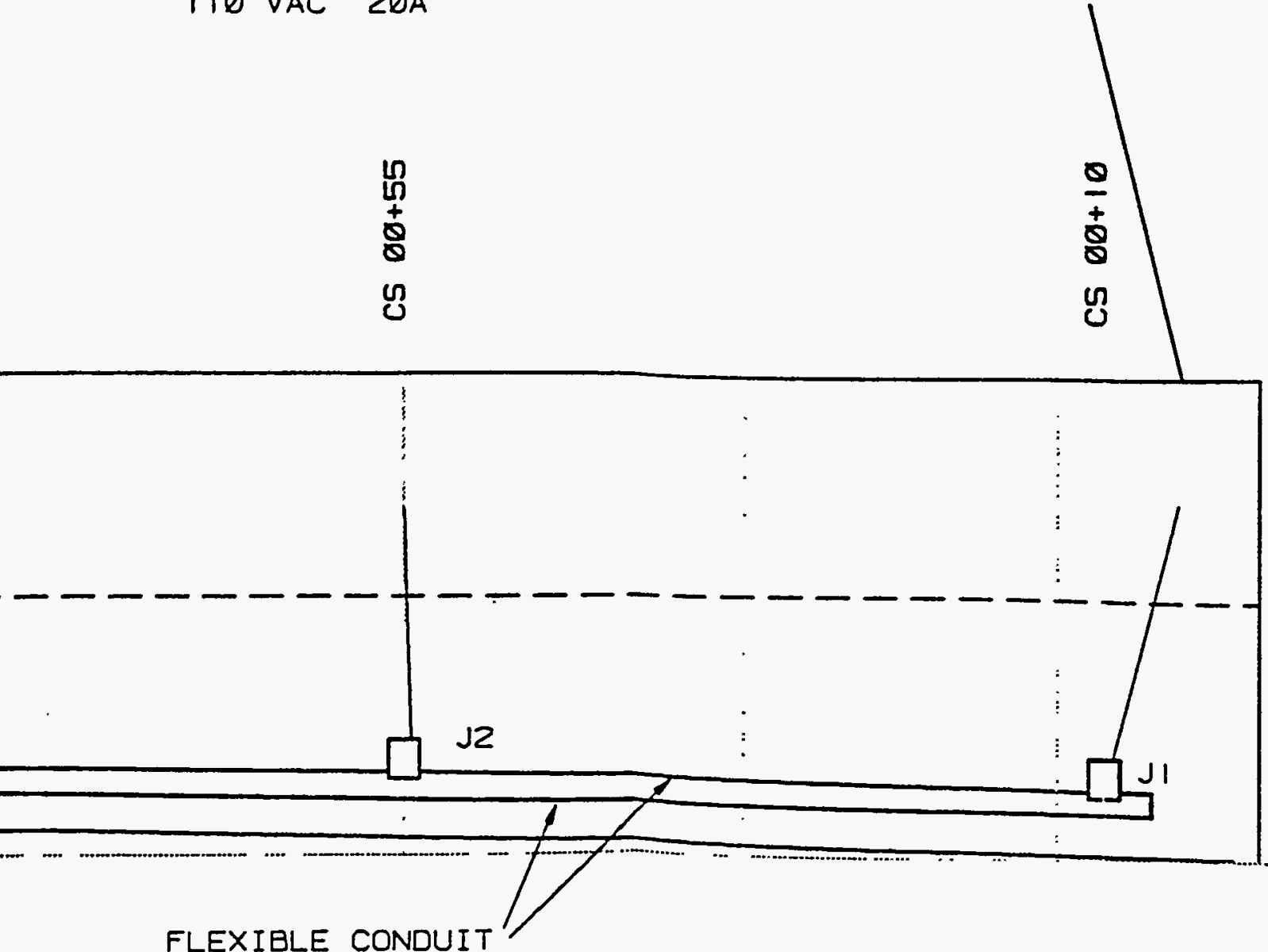

$\stackrel{\infty}{ \pm}$

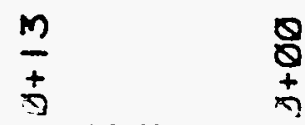




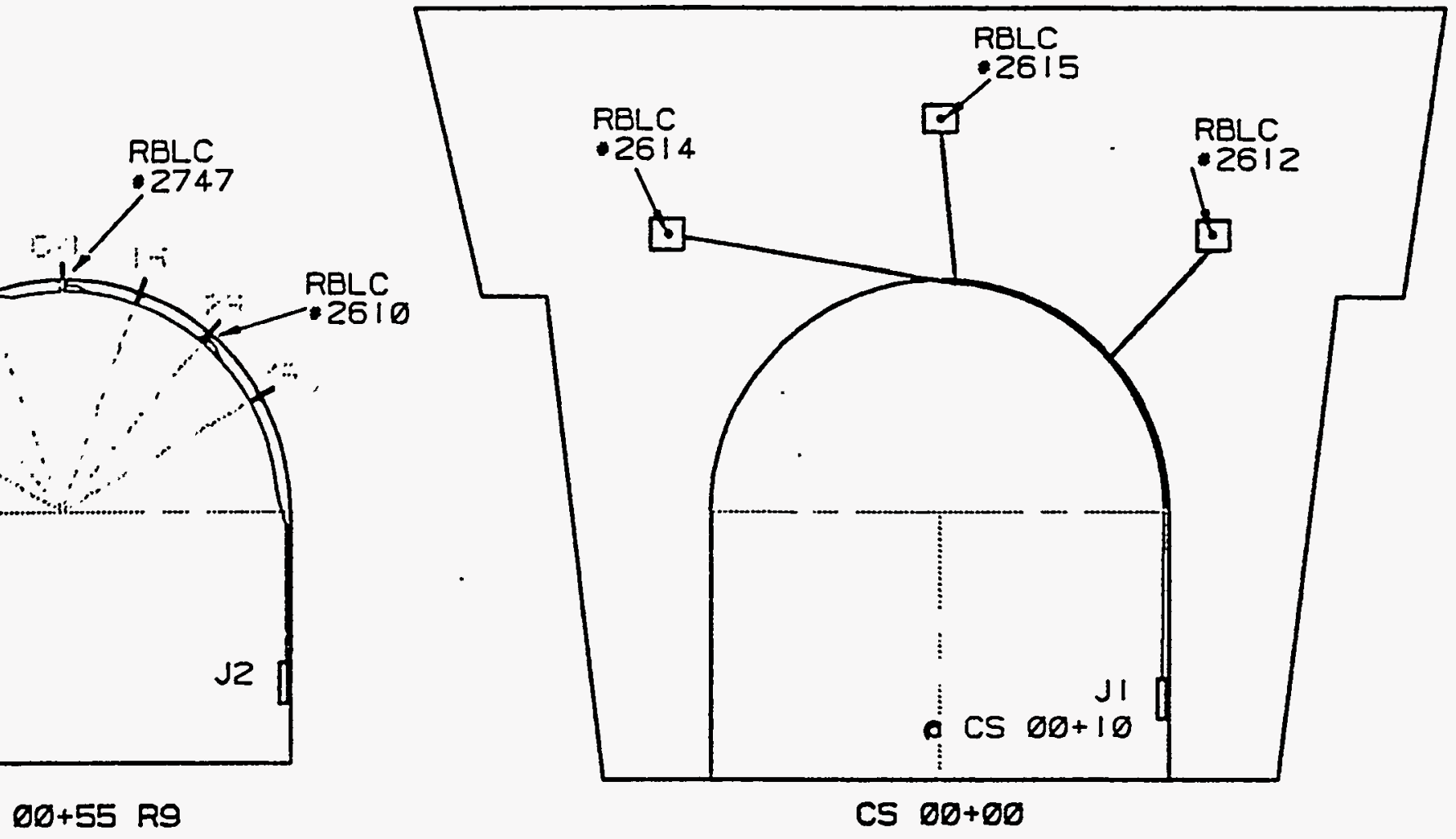

CANS ARE TO BE MOUNTED TO THE RIB WITH CENTER OF CAN AT 5. JURED INVERT.

IS JI THRU J6 AND THE DATA LOGGER CAN ARE FURNISHED BY SANDIA.

IS JI THRU J6 ARE $30^{\prime \prime} \times 24^{\prime \prime} \times 6^{\prime \prime}$.

SGER NEMA CAN IS $36^{n} \times 36^{n} \times 12$

IZES AND TYPES.

RANSDUCER

MPBX

RBLC

PRESSURE CELL
CABLE TYPE 7 PAIR 3SPS $\bullet 16$

QUAD 20 TSP
CABLE O/D SIZE

$1 / 2^{\circ}$

5/8"

$1 / 4^{\prime \prime}$

$3 / 4^{\circ}$

AND ASSOCIATED HARDWARE SUPPLIED AND INSTALLED BY REECO. IA =EニニESENTS REEC。 RESPNSIBILITY. 


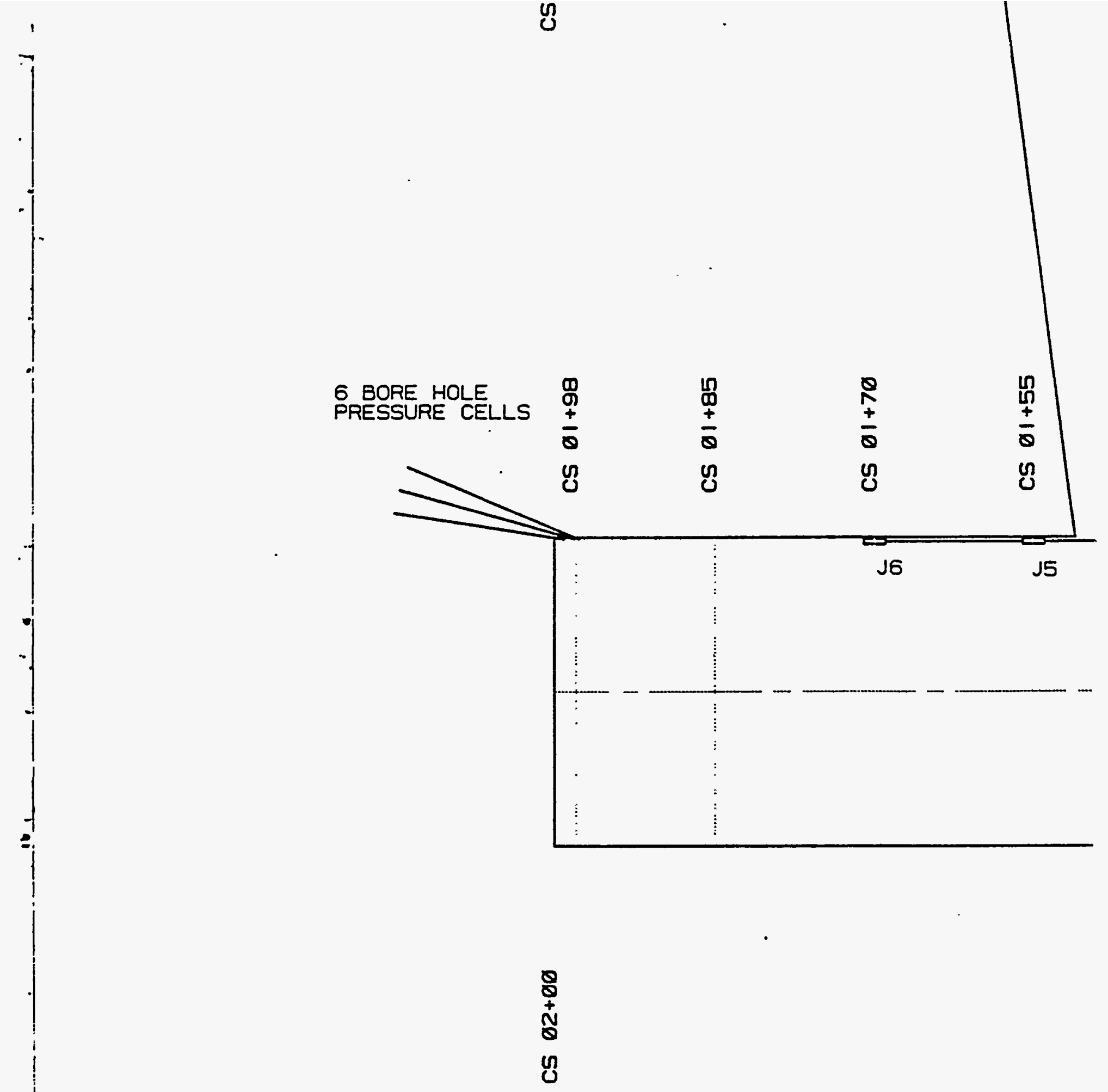




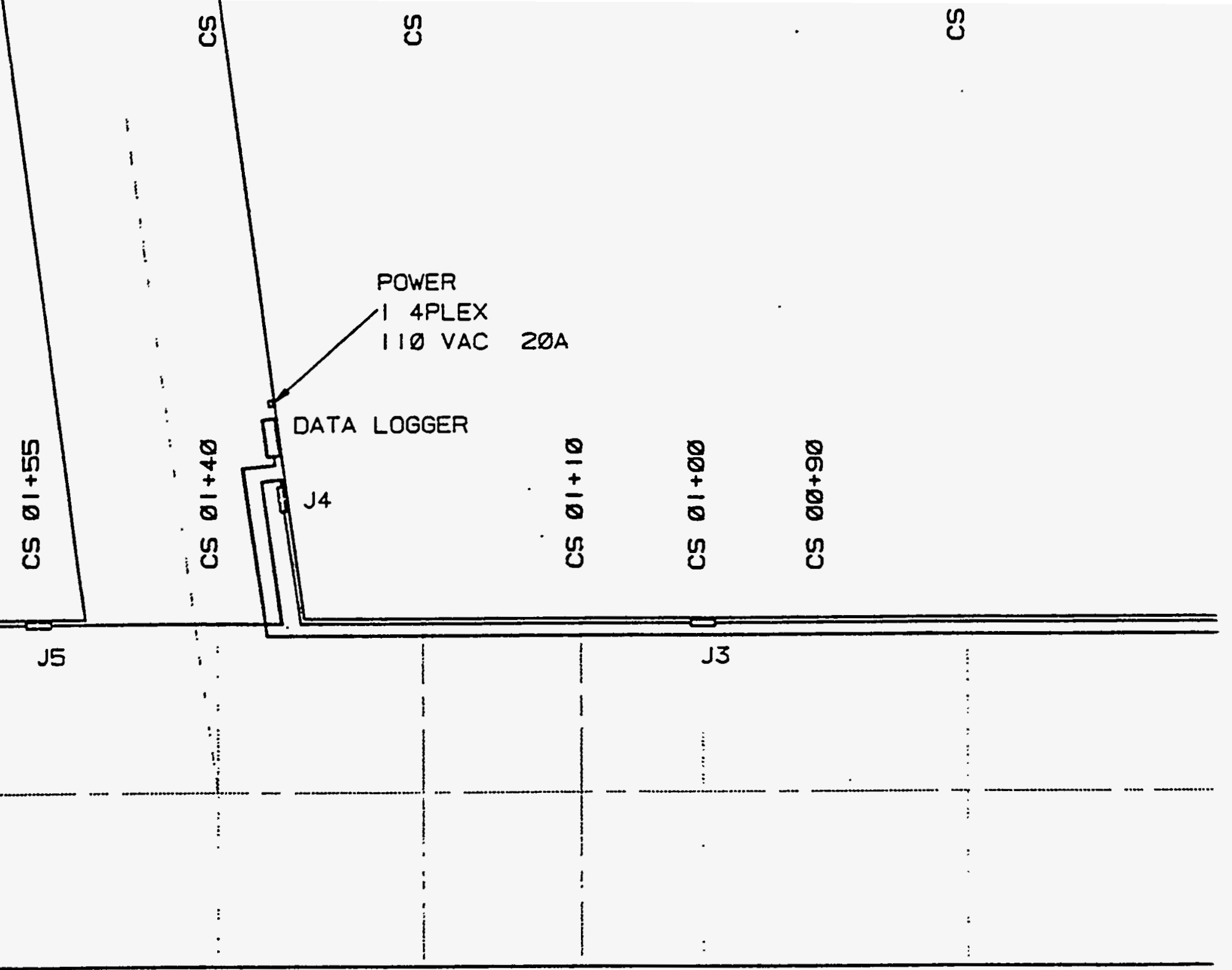

PLAN VIEW

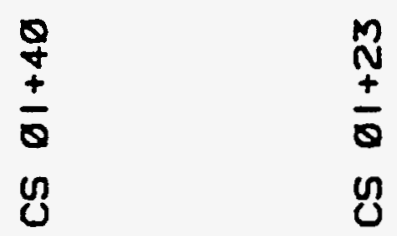

$\infty$
+
0
0
0 


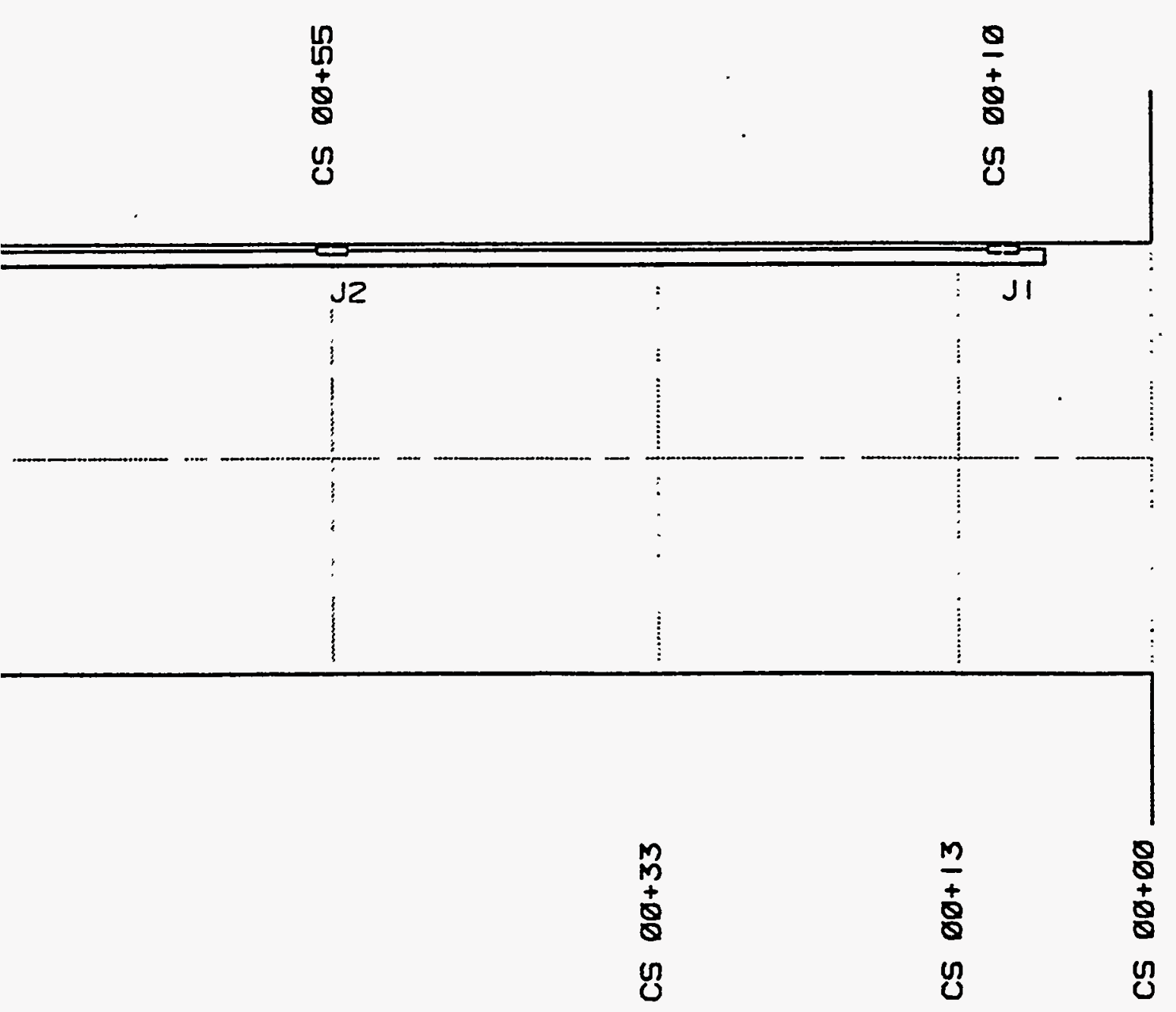


9. 20 TSP CABLE IS RUN BETWEEN NEMA CANS

10. MPBX CABLES INSTALLED IN FLEXIBLE CON 11. PRESSURE CELL CABLES INSTALLED IN FLE: 12. ROCK BOLT LOAD CELL CABLES DO NOT REO

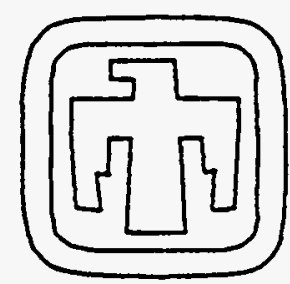

Sandio $\mathbb{N}$

YUCCA MOUN

INSTRUMENT,

DRAWING \#E

$12-1-93$ 
SURE CELL CABLES INSTALLED IN FLEXIBLE CONDUIT FROM DRILL HOLE EMA CAN.

BOLT LÓD CELL CABLES DO NOT REOUIRE CONDUIT TO NEMA CAN.

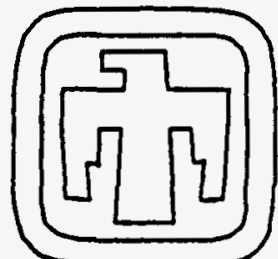

Sandia National Laboratories

YUCCA MOUNTAIN PROJECT

INSTRUMENTATION LAYOUT

DRAWING \#ESFDEF

12-1-93 JERRY CHAEL ORG 9324

PHONE (7Ø2) 295-491। 
Rev 1

\section{Appendix D \\ U.S. Bureau of Reclamation \\ Full Periphery Map/Starter Tunnel \\ DTN: GS940208314224.002}


(1) Di sti nct shear zone I ntersects crown centerll ne at: contl nues I nto $r$ ght wall as I ntensel y fractured zor surfaces coated wl th up to $3 \mathrm{~cm}$ of opal and cal cl te.

\& Shear zone wi th breccl $a$, no observed di spl acement ne termi nates in possl bl e cooll ing fracture Sta. $0+57$.

(3) Sta. $0+05$ to $0+20, \mathrm{LI}$ thophysae aspect ratl os range to 311 in upper hal $f$ of tunnel.

(4) Cooll ing fracture $w \mid$ th bedded sand I nfl || $\mid n g$, exhl b| on fracture surfaces consl stl ng of el ongate, anastor subparall el channels extendl ng $5 \mathrm{~mm}$ I nto the wall roc bounds a shear zone strl kl ng $235^{\circ}$, dl ppl ng 70-83. st

(5) Shear zone $w 1$ th crushed rock and breccl $a$.

(6) Zone of I ntensel y fractured rock I ntersectl ng tunnel In the left wall and Sta. $1+15$ in the $r l$ ght wall.

$\diamond$ Brownl sh gray to gray, densel y wel ded, rhyoll tl c, as LI thophysae comprl se approxl matel y 5-10\% of the rock average di ameter 7-20 cm) (1 thophysae less than 1.5 fllled wl th drusy quartz and opal.

8) Foll atl on more promi nent in crown, and combl ned wi th fracture causes fall out resul ting in small wedge-sha crown.

Faul $t$ wi th crushed wall rock and sandy I nflllling. F is offset approxl matel y $1.5 \mathrm{ft}$.

LI thophysae: oblate to spherol dal; average sl ze $5 \mathrm{C}$ from Sta. $0+92$ to Sta. $1+00$, from Sta. $1+00$ to $1+05$ $20 \mathrm{~cm}$, maxl mum sl ze $1545 \mathrm{~cm}$. 
e at Sta. $0+17$ and Id zone. Fracture id te.

ent near crown, +57 .

ange from $1,4(L, H)$

xhl bi ts decoratl ons iastomosl ng to 1 rock. The fracture $33^{\circ} \mathrm{SW}$.

tunnel at Sta. $0+50$

1 .

c) ash-fl ow tuff,

e rock by vol umes

$11,5 \mathrm{~cm}$ are typl cally

$*$ wi th hl gh-angle je-shaped casts in the

19. Follatl on trace

:e $5 \mathrm{~cm}$ di ameter $1+05$ average si ze is

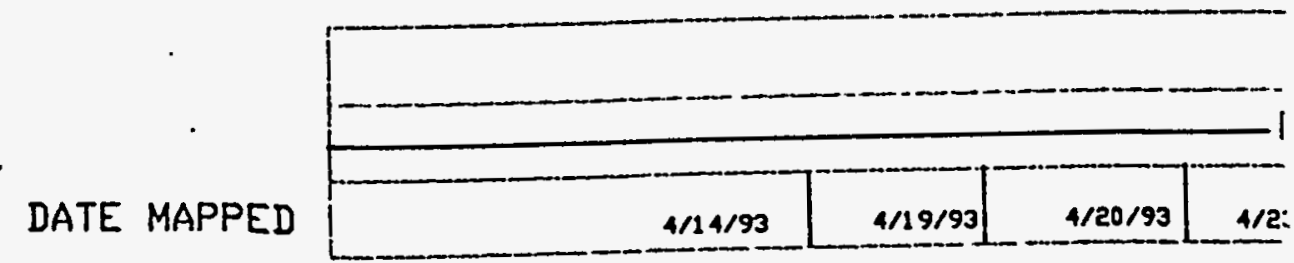

BASE IF LEFT HALL

LEFT SPRING LINE
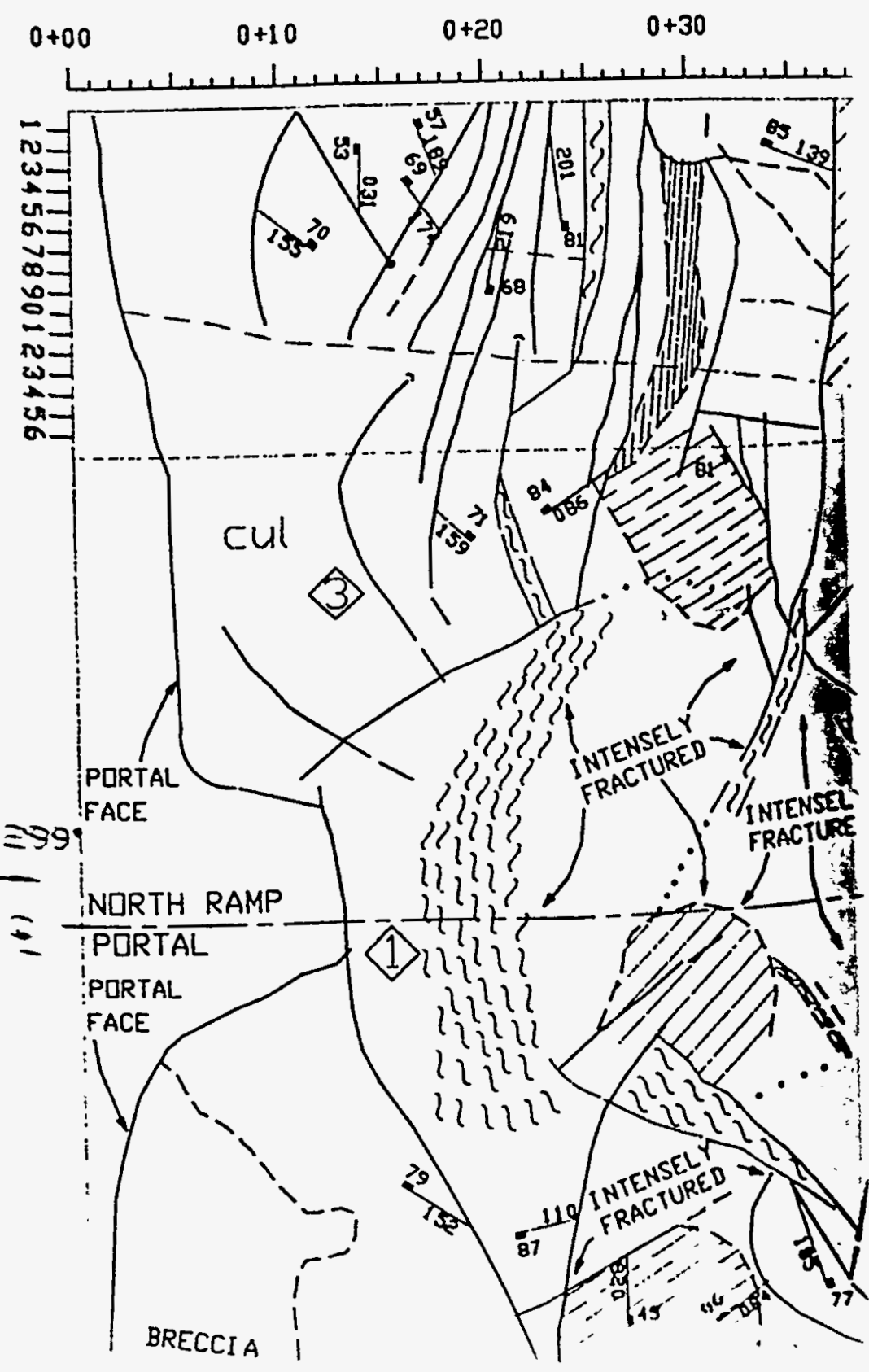


\section{SKETCH GFTUNNEL FACE STATI $\mathrm{TNN} 1+96$}

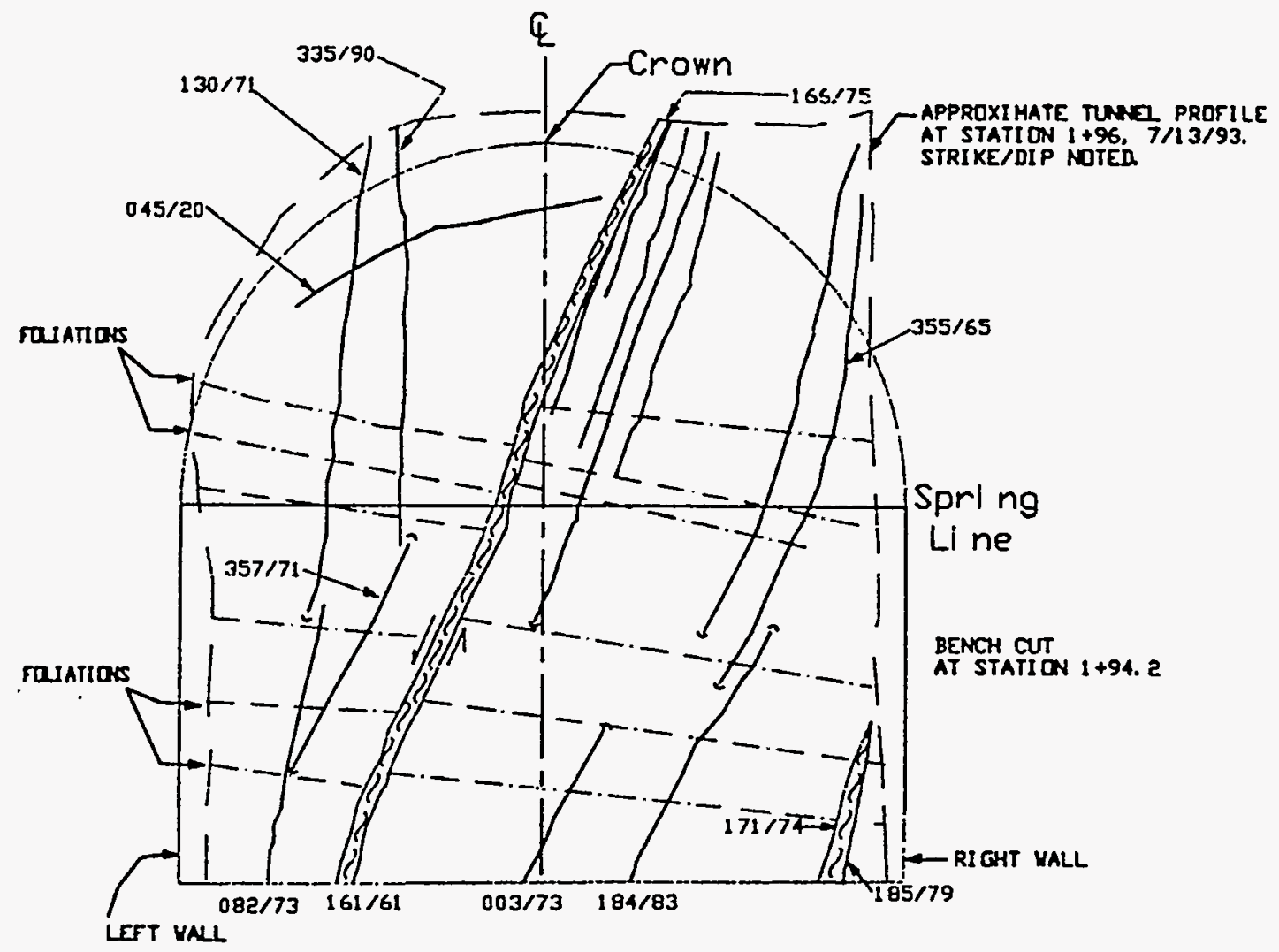








Rev 1

\section{Appendix E \\ NRST Top Heading and Alcove No. 1 Blast Monitoring Data}


Rev 1

\section{Table E-1. Peak Particle Velocity, Distance, and Explosive Charge Weight-Top Heading}

\begin{tabular}{|c|c|c|c|c|c|}
\hline $\begin{array}{c}\text { PPV } \\
\text { (in/sec) }\end{array}$ & $\begin{array}{c}\text { Distance (R) } \\
\text { (ft) }\end{array}$ & $\begin{array}{l}\text { Explosive Charge } \\
\text { Weight (W) (lbs) }\end{array}$ & $\begin{array}{l}\mathrm{R} / \mathrm{W}^{1 / 2} \\
\left(\mathrm{ft} / \mathrm{lb}^{1 / 2}\right)\end{array}$ & $\begin{array}{c}\mathbf{R} / \mathbf{W}^{1 / 3} \\
\left(\mathbf{f t} / \mathbf{l b}^{1 / 3}\right)\end{array}$ & $\begin{array}{c}\text { Blasting } \\
\text { Seismograph }\end{array}$ \\
\hline 0.06 & 200 & 1 & 200 & 200 & EV 6000 PDs \\
\hline 0.55 & 76 & 4 & 38 & 48 & \\
\hline 0.43 & 81 & 6 & 33 & 44 & \\
\hline 0.41 & 85 & 3 & 49 & 59 & \\
\hline 0.47 & 95 & 3 & 55 & 66 & \\
\hline 0.33 & 102 & 6 & 42 & 56 & \\
\hline 0.36 & 105 & 2 & 75 & 84 & \\
\hline 0.30 & 111 & 4 & 56 & 70 & \\
\hline 0.18 & 118 & 12 & 34 & 51 & \\
\hline 0.20 & 122 & 29 & 23 & 40 & \\
\hline 0.10 & 127 & 1 & 127 & 127 & \\
\hline 1.54 & 46 & 2 & 33 & 37 & \\
\hline 0.56 & 51 & 1 & 51 & 51 & \\
\hline 0.41 & 138 & 5 & 62 & 81 & \\
\hline 0.49 & 145 & 30 & 27 & 47 & \\
\hline 0.45 & 153 & 2 & 108 & 122 & \\
\hline 0.53 & 158 & 10 & 50 & - 73 & \\
\hline 0.36 & 165 & 7 & 62 & 86 & \\
\hline 0.19 & 172 & 13 & 48 & 73 & \\
\hline 0.22 & 172 & 15 & 45 & 70 & \\
\hline 0.24 & 181 & 4 & 91 & 114 & \\
\hline 0.19 & 188 & 11 & 57 & 85 & \\
\hline 0.20 & 203 & 6 & 83 & 112 & \\
\hline 0.16 & 213 & 24 & 43 & 74 & \\
\hline 0.28 & 220 & 7 & 83 & 115 & \\
\hline 0.08 & 228 & 5 & 102 & 133 & \\
\hline 0.11 & 235 & 9 & 78 & 113 & \\
\hline 0.18 & 243 & 7 & 92 & 127 & \\
\hline 0.16 & 254 & 7 & 96 & 133 & \\
\hline 0.25 & 204 & 4 & 102 & 128 & EV II PDs \\
\hline 0.07 & 210 & 6 & 86 & 115 & \\
\hline 0.13 & 214 & 3 & 124 & 149 & \\
\hline 0.86 & 41 & 3 & 24 & 28 & \\
\hline 0.86 & 45 & 6 & 19 & 25 & \\
\hline 0.51 & 48 & 2 & 34 & 38 & \\
\hline 0.37 & 53 & 4 & 27 & 33 & \\
\hline 0.33 & 59 & 12 & 17 & 26 & \\
\hline 0.26 & 63 & 29 & 12 & 21 & \\
\hline 0.15 & 67 & 1 & 67 & 67 & \\
\hline
\end{tabular}




\section{Rev 1}

Table E-1 continued

\begin{tabular}{|c|c|c|c|c|c|}
\hline $\begin{array}{c}\text { PPV } \\
\text { (in/sec) }\end{array}$ & $\begin{array}{c}\text { Distance (R) } \\
\text { (ft) }\end{array}$ & $\begin{array}{l}\text { Explosive Charge } \\
\text { Weight (W) (lbs) }\end{array}$ & $\begin{array}{l}\mathbf{R} / \mathbf{W}^{1 / 2} \\
\left(\mathbf{f t} / \mathbf{b}^{1 / 2}\right)\end{array}$ & $\begin{array}{l}R / W^{1 / 3} \\
\left(\mathbf{f t} / / \mathbf{b}^{1 / 3}\right)\end{array}$ & $\begin{array}{c}\text { Blasting } \\
\text { Seismograph }\end{array}$ \\
\hline 0.35 & 68 & 2 & 48 & 54 & \\
\hline 0.24 & 73 & 1 & 73 & 73 & \\
\hline 0.45 & 77 & 5 & 35 & 45 & \\
\hline 0.27 & 85 & 30 & 15 & 27 & \\
\hline 0.33 & 92 & 2 & 65 & 73 & \\
\hline 0.18 & 104 & 7 & 39 & 54 & \\
\hline 0.19 & 110 & 13 & 31 & 47 & \\
\hline 0.22 & 110 & 15 & 29 & 45 & \\
\hline 0.15 & 120 & 4 & 60 & 75 & \\
\hline 0.16 & 134 & 5 & 60 & 79 & \\
\hline 0.21 & 141 & 6 & 58 & 78 & \\
\hline 0.18 & 151 & 24 & 31 & 52 & \\
\hline 0.88 & 72 & 7 & 27 & 38 & EV 6000 NSs \\
\hline 0.96 & 76 & 4 & 38 & 48 & \\
\hline 0.50 & 76 & 8 & 27 & 38 & \\
\hline 1.16 & 85 & 21 & 19 & 31 & \\
\hline 1.15 & 92 & 12 & 27 & 40 & \\
\hline 0.49 & 93 & 14 & 25 & 39 & \\
\hline 0.81 & 100 & 20 & 22 & 37 & \\
\hline 0.47 & 108 & 6 & 44 & 60 & \\
\hline 0.47 & 119 & 33 & 21 & 37 & \\
\hline 0.84 & 128 & 5 & 57 & 75 & \\
\hline 0.31 & 136 & 60 & 18 & 35 & \\
\hline 0.67 & 144 & 19 & 33 & 54 & \\
\hline 0.37 & 153 & 20 & 34 & 56 & \\
\hline 0.18 & 158 & 7 & 60 & 83 & \\
\hline 0.18 & 165 & 18 & 39 & 63 & \\
\hline 0.29 & 172 & 4 & 86 & 108 & \\
\hline 0.31 & 202 & 15 & 52 & 82 & \\
\hline 0.24 & 210 & 32 & 37 & 66 & \\
\hline 0.32 & 220 & 18 & 52 & 84 & \\
\hline 0.23 & 228 & 16 & 57 & 90 & \\
\hline 0.25 & 235 & 22 & 50 & 84 & \\
\hline 0.18 & 254 & 5 & 114 & 149 & \\
\hline 0.13 & 254 & 24 & 52 & 88 & \\
\hline 3.36 & 32 & 4 & 16 & 20 & EV II NSs \\
\hline 2.33 & 32 & 8 & 11 & 16 & \\
\hline 3.71 & 35 & 21 & 8 & 13 & \\
\hline 2.05 & 39 & 12 & 11 & 17 & \\
\hline 1.85 & 40 & 14 & 11 & 16 & \\
\hline 1.24 & 44 & 20 & 10 & 16 & \\
\hline 0.53 & 51 & 6 & 21 & 28 & \\
\hline
\end{tabular}


SAND95-1675

Rev 1

Table E-1 continued

\begin{tabular}{cccccc}
$\begin{array}{c}\text { PPV } \\
\text { (in/sec) }\end{array}$ & $\begin{array}{c}\text { Distance (R) } \\
(\mathbf{f t})\end{array}$ & $\begin{array}{c}\text { Explosive Charge } \\
\text { Weight (W) (lbs) }\end{array}$ & $\begin{array}{c}\mathbf{R} / \mathbf{W}^{\mathbf{1 / 2}} \\
\left(\mathbf{f t} / \mathbf{b}^{\mathbf{1} / 2}\right)\end{array}$ & $\begin{array}{c}\mathbf{R} / \mathbf{W}^{\mathbf{1 / 3}} \\
\left(\mathbf{f t} / \mathbf{b}^{1 / 3}\right)\end{array}$ & $\begin{array}{c}\text { Blasting } \\
\text { Seismograph }\end{array}$ \\
\hline 0.67 & 60 & 33 & 10 & 19 & \\
0.40 & 68 & 5 & 31 & 40 & \\
0.29 & 76 & 60 & 10 & 19 & \\
0.35 & 83 & 19 & 19 & 31 & \\
0.39 & 92 & 20 & 21 & 34 & \\
0.26 & 97 & 7 & 37 & 51 & \\
0.18 & 104 & 18 & 24 & 40 & \\
0.22 & 110 & 4 & 55 & 69 & \\
0.18 & 114 & 9 & 38 & 55 & \\
0.18 & 127 & 11 & 38 & 57 & \\
0.19 & 134 & 11 & 41 & 60 & \\
0.23 & 140 & 15 & 36 & 57 & \\
0.28 & 148 & 32 & 26 & 47 & EV 6000 SSs \\
0.56 & 74 & 1 & 74 & 74 & EV II SSs \\
0.70 & 32 & 1 & 32 & 32 & \\
\hline \hline
\end{tabular}


Table E-2. Near-Field Blast Data from Alcove No. 1 (data sorted by PPV)

\begin{tabular}{|c|c|c|c|c|c|}
\hline $\begin{array}{c}\text { PPV } \\
\text { (in/sec) }\end{array}$ & $\begin{array}{c}\text { Distance (R) } \\
(\mathbf{f t})\end{array}$ & $\begin{array}{l}\text { Explosive Charge } \\
\text { Weight (W) (lbs) }\end{array}$ & $\begin{array}{c}\mathrm{R} / \mathbf{W}^{1 / 2} \\
\left(\mathrm{ft} / \mathbf{l b}^{1 / 2}\right)\end{array}$ & $\begin{array}{c}\mathbf{R} / \mathbf{W}^{1 / 3} \\
\left(\mathbf{f t} / \mathbf{l b}^{1 / 3}\right)\end{array}$ & $\begin{array}{c}\text { Blasting } \\
\text { Seismograph }\end{array}$ \\
\hline 43.30 & 12 & 6 & 4.90 & 6.64 & TA 3 Near \\
\hline 43.30 & 8 & 3 & 4.62 & 5.57 & TA 3 Near \\
\hline 43.30 & 3 & 24 & 0.61 & 1.05 & TA 4 Near \\
\hline 29.18 & 11 & 3 & 6.35 & 7.65 & TA 3 Near \\
\hline 27.34 & 9 & 3 & 5.20 & 6.26 & TA 4 Near \\
\hline 25.37 & 13 & 3 & 7.51 & 9.05 & TA 3 Far \\
\hline 24.60 & 8 & 24 & 1.63 & 2.80 & TA 4 Far \\
\hline 24.23 & 17 & 6 & 6.94 & 9.41 & TA 3 Far \\
\hline 22.77 & 14 & 3 & 8.08 & 9.74 & TA 4 Far \\
\hline 22.44 & 11 & 12 & 3.18 & 4.84 & TA 3 Far \\
\hline 20.84 & 8 & 1 & 8.00 & 8.00 & TA 1 Near \\
\hline 20.12 & 12 & 10 & 3.79 & 5.61 & TA 1 Near \\
\hline 19.99 & 12 & 3 & 6.93 & 8.35 & TA 3 Near \\
\hline 17.79 & 6 & 12 & 1.73 & 2.64 & TA 3 Near \\
\hline 16.25 & 16 & 3 & 9.24 & 11.13 & TA 3 Far \\
\hline 15.73 & 17 & 10 & 5.38 & 7.95 & -TA 1 Far \\
\hline 12.62 & 17 & 3 & 9.81 & 11.83 & TA 3 Far \\
\hline 11.91 & 5 & 7 & 1.89 & 2.63 & TA 1 Near \\
\hline 11.04 & 13 & 1 & 13.00 & 13.00 & TA 1 Far \\
\hline 11.00 & 13 & 21 & 2.73 & 4.58 & TA 4 Far \\
\hline 10.93 & 3 & 19 & 0.69 & 1.14 & TA 3 Near \\
\hline 10.88 & 8 & 21 & 1.64 & 2.75 & TA 4 Near \\
\hline 10.62 & 8 & 19 & 1.84 & 3.03 & TA 3 Far \\
\hline 8.39 & 13 & 11 & 3.92 & 5.89 & TA 3 Near \\
\hline 7.95 & 8 & 1 & 8.00 & 8.00 & TA 1 Far \\
\hline 7.37 & 10 & 6 & 4.08 & 5.54 & TA 4 Near \\
\hline 7.19 & 18 & 11 & 5.43 & 8.16 & TA 3 Far \\
\hline 6.81 & 12 & 3 & 6.93 & 8.35 & TA 4 Near \\
\hline 6.19 & 12 & 6 & 4.90 & 6.64 & TA 4 Near \\
\hline 6.06 & 3 & 1 & 3.00 & 3.00 & TA 1 Near \\
\hline 5.10 & 17 & 6 & 6.94 & 9.41 & TA 4 Far \\
\hline 5.10 & 15 & 6 & 6.12 & 8.30 & TA 4 Far \\
\hline 4.98 & 12 & 3 & 6.93 & 8.35 & TA 4 Near \\
\hline 4.98 & 12 & 3 & 6.93 & 8.35 & TA 4 Near \\
\hline 4.88 & 12 & 6 & 4.90 & 6.64 & TA 4 Near \\
\hline 4.78 & 11 & 9 & 3.67 & 5.33 & TA 4 Near \\
\hline 4.32 & 5 & 3 & 2.89 & 3.48 & TA 4 Near \\
\hline 4.06 & 10 & 7 & 3.78 & 5.26 & TA 1 Far \\
\hline 4.06 & 17 & 3 & 9.81 & 11.83 & TA 4 Far \\
\hline 3.68 & 17 & 3 & 9.81 & 11.83 & TA 4 Far \\
\hline
\end{tabular}


SAND95-1675

Rev 1

Table E-2 continued

\begin{tabular}{cccccc}
$\begin{array}{c}\text { PPV } \\
\text { (in/sec) }\end{array}$ & $\begin{array}{c}\text { Distance (R) } \\
(\mathbf{f t})\end{array}$ & $\begin{array}{c}\text { Explosive Charge } \\
\text { Weight (W) (lbs) }\end{array}$ & $\begin{array}{c}\mathbf{R} / \mathbf{W}^{1 / 2} \\
\left(\mathbf{f t} / \mathbf{b}^{1 / 2}\right)\end{array}$ & $\begin{array}{c}\mathbf{R} / \mathbf{W}^{1 / 3} \\
\left(\mathbf{f t} / \mathbf{b}^{1 / 3}\right)\end{array}$ & $\begin{array}{c}\text { Blasting } \\
\text { Seismograph }\end{array}$ \\
\hline 3.68 & 17 & 3 & 9.81 & 11.83 & TA 4 Far \\
3.26 & 10 & 3 & 5.77 & 6.96 & TA 4 Far \\
2.89 & 16 & 9 & 5.33 & 7.75 & TA 4 Far \\
2.83 & 17 & 6 & 6.94 & 9.41 & TA 4 Far \\
\hline \hline
\end{tabular}


Rev 1

\section{Appendix F}

\section{Empirical Ground Support Design Category \\ (from Barton et al. 1974)}




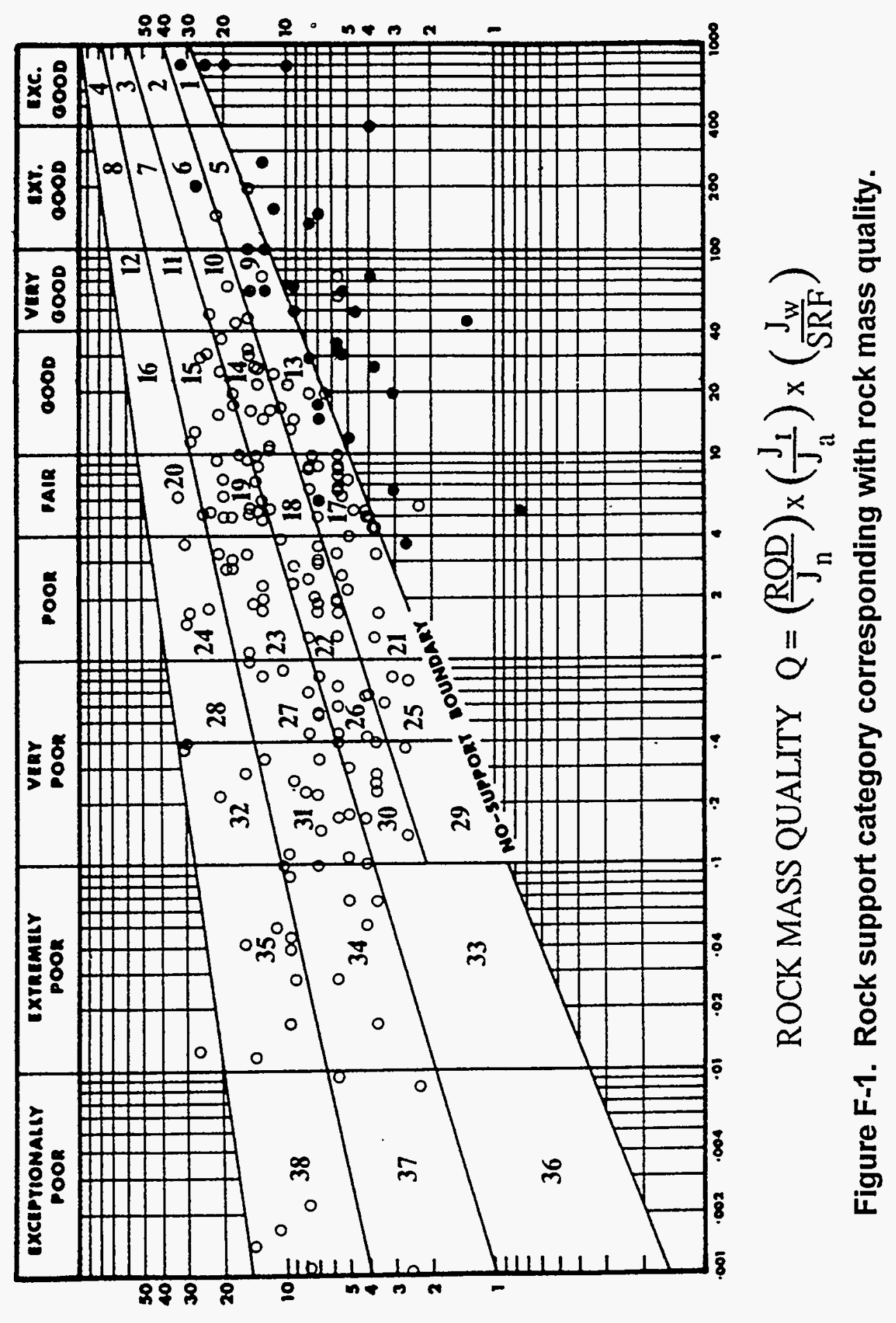

(u) $\mathrm{yS} / \mathrm{N} \forall \mathrm{dS}$ 
Kay to Support Tables:

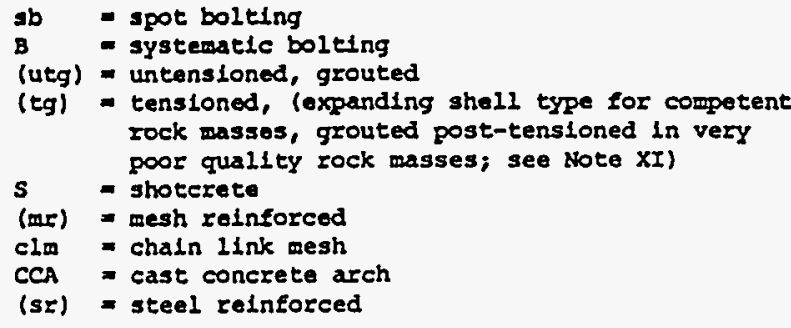

Bolt spacingsare given in metres (m). Shotcrete, or cast concrete arch thickness is given in centimetres (cis).

Tabla 8. Support Measures for Rock Masses of "Exaptional". "Extremely Good", "Very Good" and "Good" suality (Q range: 1000-10)

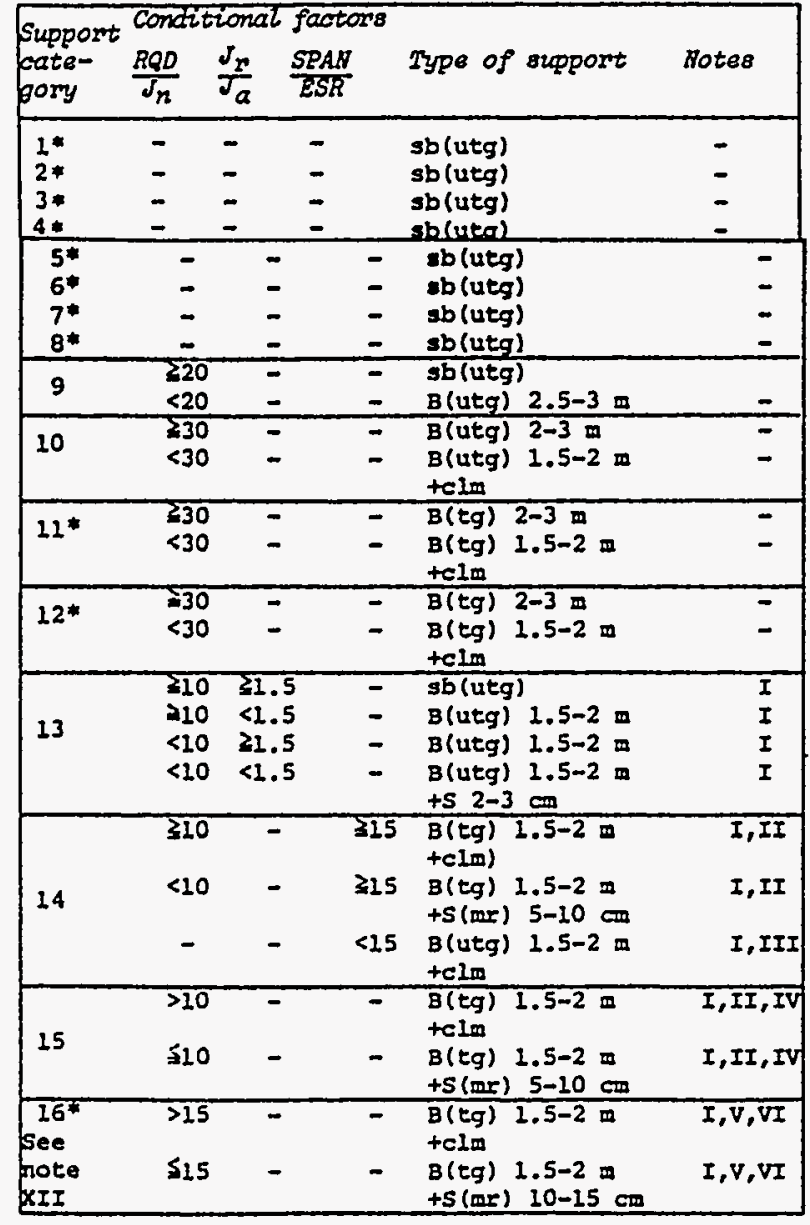

"Authors' estimates of support. Insufficient case records avaflable for rellable estimation of support requirements.
Note: The type of support to be used in categorles 1 to 8 will depend on the blasting technlque. Smooth wall blasting and thorough barring-down may remove the need for support. Rough-wall blasting may result in the need for single applications of shotcrete, especially where the excavation height is $>25 \mathrm{~m}$. Future case records should differentiate categorles 1 to 8 .

Table 9. Support Heasures for Rock Nasses of "Fair" and "Poor" quality (Q ronge: 10-1).

\begin{tabular}{|c|c|c|c|c|c|}
\hline $\begin{array}{l}\text { Support } \\
\text { cate- } \\
\text { gory }\end{array}$ & $\begin{array}{l}\text { Condit } \\
\frac{R Q D}{J_{n}}\end{array}$ & $\begin{array}{l}\operatorname{mal}_{r} f a \\
\frac{J_{a}}{J_{a}}\end{array}$ & $\begin{array}{l}\text { retors } \\
\frac{\text { SPAN }}{E S R}\end{array}$ & Type of aupport & Note \\
\hline 17 & $\begin{array}{l}>30 \\
\left(\begin{array}{l}30 \\
\leqslant 30 \\
<10\end{array}\right) \\
<10\end{array}$ & $\begin{array}{l}- \\
- \\
-\end{array}$ & $\begin{array}{l}- \\
- \\
\geqslant 6 \mathrm{~m} \\
<6 \mathrm{~m}\end{array}$ & $\begin{array}{l}\text { sb(utg) } \\
\text { B(utg) } 1-1.5 \mathrm{~m} \\
B \text { (utg) } 1-1.5 \mathrm{~m} \\
+52-3 \mathrm{~cm} \\
S 2-3 \mathrm{~cm}\end{array}$ & $\begin{array}{l}I \\
I \\
I \\
I\end{array}$ \\
\hline 18 & $\begin{array}{l}>5 \\
>5 \\
\leqq 5 \\
\leqq 5\end{array}$ & $\begin{array}{l}- \\
- \\
- \\
-\end{array}$ & $\begin{array}{l}\geq 10 \mathrm{~m} \\
<10 \mathrm{~m} \\
\geq 10 \mathrm{~m} \\
<10 \mathrm{~m}\end{array}$ & $\begin{array}{l}B(t g) 1-1.5 \mathrm{~m} \\
+c l m \\
B(u t g) 1-1.5 \mathrm{~m} \\
+c l m \\
B(t g) 1-1.5 \mathrm{~m} \\
+S 2-3 \mathrm{~cm} \\
B(u t g) 1-1.5 \mathrm{~m} \\
+S 2-3 \mathrm{~cm}\end{array}$ & $\begin{array}{l}I, I I I \\
I \\
I, I I I \\
I\end{array}$ \\
\hline 19 & $\begin{array}{l}- \\
-\end{array}$ & $\begin{array}{l}- \\
-\end{array}$ & $\begin{array}{l}\geq 20 \text { a } \\
<20 \text { a }\end{array}$ & $\begin{array}{l}B(t g) \quad 1-2 \mathrm{~m} \\
+S(m x) 10-15 \mathrm{~cm} \\
B(t g) \quad 1-1.5 \mathrm{~m} \\
+5 \text { (mr) } 5-10 \mathrm{~cm}\end{array}$ & $\begin{array}{l}I, I I, I V \\
I, I I\end{array}$ \\
\hline \begin{tabular}{|l}
$20^{*}$ \\
See \\
note \\
XII \\
\end{tabular} & $\begin{array}{l}- \\
-\end{array}$ & $\begin{array}{l}- \\
-\end{array}$ & $\begin{array}{l}\ 35 \mathrm{~m} \\
<35 \mathrm{~m}\end{array}$ & $\begin{array}{l}\text { B(tg) } 1-2 \mathrm{~m} \\
+S(\mathrm{mr}) 20-25 \mathrm{~cm} \\
B(t g) 1-2 \mathrm{~m} \\
+S(\mathrm{mr}) 10-20 \mathrm{~cm}\end{array}$ & $\begin{array}{l}I, V, V I \\
I, I I, I V\end{array}$ \\
\hline 21 & $\begin{array}{l}\geq 12.5 \\
<12.5 \\
-\end{array}$ & $\begin{array}{l}\leq 0.75 \\
\leq 0.75 \\
>0.75\end{array}$ & $\overline{-}$ & $\begin{array}{l}\text { B(utg) } 1 \mathrm{a} \\
+52-3 \mathrm{~cm} \\
52.5-5 \mathrm{~cm} \\
\text { B(utg) } 1 \mathrm{~m}\end{array}$ & $I$ \\
\hline 22 & $\begin{array}{l}>10, \\
<30 \\
\leqq 10 \\
<30 \\
\geqq 30\end{array}$ & $\begin{array}{l}>1.0 \\
>1.0 \\
\leqq 1.0 \\
\end{array}$ & - & $\begin{array}{l}\text { (B(utg) I } \\
+c 1 \mathrm{~m} \\
\mathrm{~S} 2.5-7.5 \mathrm{~cm} \\
B(\text { utg). } 1 \mathrm{~m} \\
+5 \text { (m) } 2.5-5 \mathrm{~cm} \\
B \text { (utg) } 1 \mathrm{~m}\end{array}$ & $\begin{array}{l}I \\
I\end{array}$ \\
\hline 23 & - & - & $\begin{array}{l}\geqq 15 \text { m } \\
<15 \text { m }\end{array}$ & $\begin{array}{l}B \text { (tg) } 1-1.5 \mathrm{~m} \\
+5 \text { (mr) } 10-15 \mathrm{~cm} \\
B(u t g) \\
+5 \text { (mr) } 5-1.5 \mathrm{~m} \\
\end{array}$ & $\begin{array}{r}I, I I, I V, \\
\text { VII }\end{array}$ \\
\hline $\begin{array}{l}24^{*} \\
\text { See } \\
\text { note } \\
\text { XII }\end{array}$ & $\overline{-}$ & - & $\begin{array}{l}\rightrightarrows 30 \mathrm{~m} \\
<30 \mathrm{~m}\end{array}$ & $\begin{array}{l}B(t g) 1-1.5 \mathrm{~m} \\
+5(\mathrm{mr}) 15-30 \mathrm{~cm} \\
B(\tau g) 1-1.5 \mathrm{~m} \\
+S \text { (mr) } 10-15 \mathrm{~cm}\end{array}$ & $\begin{array}{l}I, V, V I \\
I, I I, I V\end{array}$ \\
\hline
\end{tabular}

*Authors' estimates of support. Insufficiene case records available for reliable estimation of support requirements. 
Rev 1

Table 10. Support Measures for Rock Hasses of "Very poor" Quality (Q range: 1.0-0.1)

\begin{tabular}{|c|c|c|c|c|c|}
\hline $\begin{array}{l}\text { Support } \\
\text { cate- } \\
\text { gory }\end{array}$ & $\begin{array}{l}\text { Conditi } \\
\frac{R Q D}{J_{n}}\end{array}$ & $\frac{J_{n}}{J_{a}}$ & $\begin{array}{l}\text { SPAN } \\
\frac{E S R}{}\end{array}$ & Type of suppont & Noto \\
\hline 25 & $\begin{array}{l}>10 \\
\$ 10 \\
-\end{array}$ & $\begin{array}{l}>0.5 \\
>0.5 \\
\leqq 0.5\end{array}$ & - & $\begin{array}{l}B(u t g) 1 \mathrm{~m} \\
+m \text { or clm } \\
B(u t g) 1 \mathrm{~m} \\
+S(m r) 5 \mathrm{~cm} \\
B(t g) 1 \mathrm{~m} \\
+S(\mathrm{mr}) 5 \mathrm{~cm}\end{array}$ & I \\
\hline 26 & - & $\begin{array}{l}- \\
-\end{array}$ & - & $\begin{array}{l}B(t g) 1 \mathrm{~m} \\
+S(m \mathrm{~m}) 5-7.5 \mathrm{~cm} \\
B(u t g) 1 \mathrm{~m} \\
+52.5-5 \mathrm{~cm}\end{array}$ & $\begin{array}{l}\text { VIII,X, } \\
X I \\
I, I X\end{array}$ \\
\hline 27 & $\begin{array}{l}- \\
- \\
-\end{array}$ & $\begin{array}{l}- \\
- \\
-\end{array}$ & $\begin{array}{l}\text { श्रा2m } \\
<12 m \\
>12 m \\
<12 m\end{array}$ & $\begin{array}{l}B \text { (tg) } 1 \mathrm{~m} \\
+S(m r) 7.5-10 \mathrm{~cm} \\
B(u t g) 1 \mathrm{~m} \\
+S(m r) 5-7.5 \mathrm{~cm} \\
C C A 20-40 \mathrm{~cm} \\
+B(t g) 1 \mathrm{~m} \\
S(m r) 10-20 \mathrm{~cm} \\
+B(t g) 1 \mathrm{~m}\end{array}$ & $\begin{array}{l}I, I X \\
I, I X \\
V I I I, X, \\
x I \\
V I I I, x, \\
X I\end{array}$ \\
\hline $\begin{array}{l}28 * \\
\text { see } \\
\text { note } \\
\text { XII }\end{array}$ & $\begin{array}{l}- \\
- \\
-\end{array}$ & $\begin{array}{l}- \\
- \\
-\end{array}$ & $\begin{array}{l}\geqslant 30 \mathrm{~m} \\
220, \\
<30 \mathrm{~m}) \\
<20 \mathrm{~m} \\
-\end{array}$ & $\begin{array}{l}\mathrm{B}(\mathrm{tg}) \mathrm{Im} \\
+S(\mathrm{mr}) 30-40 \mathrm{~cm} \\
\mathrm{~B}(\mathrm{tg}) 1 \mathrm{~m} \\
+S(\mathrm{mr}) 20-30 \mathrm{~cm} \\
\mathrm{~B}(\mathrm{tg}) 1 \mathrm{~m} \\
+S(\mathrm{mr}) 15-20 \mathrm{~cm} \\
C C A(\mathrm{sr}) 30-100 \mathrm{~cm} \\
+B(t g) 1 \mathrm{~m}\end{array}$ & $\begin{array}{r}I, I V, V, \\
I X \\
I, I I, I V, \\
I X \\
I, I I, I X \\
I V, V I I I, \\
x, X I\end{array}$ \\
\hline $29 *$ & $\begin{array}{l}>5 \\
\leq 5 \\
-\end{array}$ & $\begin{array}{l}>0.25 \\
>0.25 \\
\leq 0.25\end{array}$ & - & $\begin{array}{l}\text { B(utg) } 1 \mathrm{~m} \\
+S 2-3 \mathrm{~cm} \\
B(u t g) 1 \mathrm{~m} \\
+5(\mathrm{mr}) 5 \mathrm{~cm} \\
B(t g) 1 \mathrm{~m} \\
+5 \text { (mr) } 5 \mathrm{~cm} \\
\end{array}$ & - \\
\hline 30 & $\begin{array}{l}\geq 5 \\
<5 \\
\end{array}$ & $\overrightarrow{-}$ & - & $\begin{array}{l}B(t g) 1 \mathrm{~m} \\
+S 2.5-5 \mathrm{~cm} \\
S(\mathrm{mr}) 5-7.5 \mathrm{~cm} \\
B(t g) 1 \mathrm{~m} \\
+S(\mathrm{mr}) 5-7.5 \mathrm{~cm}\end{array}$ & $\begin{array}{l}I X \\
I X \\
Y I I I, X, \\
X I\end{array}$ \\
\hline $3 I$ & $\begin{array}{l}>4 \\
\leq 4, \geqq 1.5 \\
<1.5 \\
-\end{array}$ & $\overrightarrow{-}$ & - & $\begin{array}{l}3(\mathrm{tg}) 1 \mathrm{~m} \\
+S(\mathrm{mr}) 5-12.5 \mathrm{~cm} \\
S(\mathrm{mr}) 7.5-25 \mathrm{~cm} \\
C C A 20-40 \mathrm{~cm} \\
+B(t g) 1 \mathrm{~m} \\
C C A(s r) 30-50 \mathrm{~cm} \\
+B(t g) 1 \mathrm{~m}\end{array}$ & $\begin{array}{l}I X \\
I X \\
I X \\
V I I, X \\
X I\end{array}$ \\
\hline $\begin{array}{l}32 \\
\text { See } \\
\text { note } \\
\text { XII }\end{array}$ & - & - & $\begin{array}{l}\geq 20 m \\
<20 m\end{array}$ & $\begin{array}{l}\text { B(tg) } 1 \mathrm{~m} \\
+S(\mathrm{mr}) 40-60 \mathrm{~cm} \\
B(t g) 1 \mathrm{~m} \\
+S(\mathrm{~m}) \text { ) 20-40 cm } \\
C C A(s r) 40-120 \mathrm{~cm} \\
+B(t g) 1 \mathrm{~m}\end{array}$ & $\begin{array}{l}I I, I V, \\
I X \\
I I I, I V, \\
I X \\
I V, V I I I, \\
X, X I\end{array}$ \\
\hline
\end{tabular}

*Authors' estimates of support. Insufficient case records available for confident prediction of support requirements.
Table 11. Support Measures for Rock Masses of "Extremely Poor" and "Exceptionally Foor" Quality (Q range: $0.1-0.001$ )

\begin{tabular}{|c|c|c|c|c|c|}
\hline $\begin{array}{l}\text { Suppor } \\
\text { cate- } \\
\text { gomy }\end{array}$ & $\begin{array}{l}\text { Conc } \\
\frac{R Q D}{J_{n}}\end{array}$ & $\begin{array}{c}\text { onal fc } \\
J_{a} \\
J_{a}\end{array}$ & $\begin{array}{l}\text { tor's } \\
\frac{S P A N}{E S R}\end{array}$ & Type of support & Note \\
\hline $33^{*}$ & $\begin{array}{l}32 \\
<2 \\
-\end{array}$ & - & $\overrightarrow{-}$ & $\begin{array}{l}B \text { (tg) } 1 \mathrm{~m} \\
+S \text { (mx) } 2.5-5 \mathrm{~cm} \\
S \text { (mr) } 5-10 \mathrm{~cm} \\
S \text { (mr) } 7.5-15 \mathrm{~cm}\end{array}$ & $\begin{array}{l}\text { IX } \\
\text { IX } \\
\text { VIII, } X\end{array}$ \\
\hline 34 & $\begin{array}{l}\geq 2 \\
<2 \\
- \\
-\end{array}$ & $\begin{array}{c}\geq 0.25 \\
\geq 0.25 \\
<0.25 \\
-\end{array}$ & $\begin{array}{l}- \\
- \\
-\end{array}$ & $\begin{array}{l}B \text { (tg) } 1 \mathrm{~m} \\
+S(\mathrm{mr}) 5-7.5 \mathrm{~cm} \\
S(\mathrm{mr}) 7.5-15 \mathrm{~cm} \\
S(\mathrm{mr}) 15-25 \mathrm{~cm} \\
C C A(\mathrm{sr}) 20-60 \mathrm{~cm} \\
+B(t g) 1 \mathrm{~m}\end{array}$ & $\begin{array}{l}I X \\
I X \\
I X \\
V I I I, X \\
X I\end{array}$ \\
\hline $\begin{array}{l}35 \\
\text { See } \\
\text { note } \\
\text { XII }\end{array}$ & - & $\begin{array}{l}- \\
-\end{array}$ & $\begin{array}{l}\geq 15 m \\
\geqq 15 m \\
<15 m \\
<15 m\end{array}$ & $\begin{array}{l}B(t g) 1 \mathrm{~m} \\
+S(m r) 30-100 \mathrm{~cm} \\
C C A(s r) 60-200 \mathrm{~cm} \\
+B(t g) 1 \mathrm{~m} \\
B(t g) 1 \mathrm{~m} \\
+S(m r) 20-75 \mathrm{~cm} \\
C C A(s r) 40-150 \mathrm{~cm} \\
+B(t g) 1 \mathrm{~m}\end{array}$ & $\begin{array}{l}I I, I X \\
\text { vIII,X, } \\
\quad X I, I I \\
I X, I I I \\
\text { vIII,X, } \\
\quad X I, I I I\end{array}$ \\
\hline $36 *$ & $\overrightarrow{-}$ & $\overline{-}$ & $\overline{-}$ & $\begin{array}{l}S(\mathrm{mr}) 10-20 \mathrm{~cm} \\
S(\mathrm{mr}) 10-20 \mathrm{~cm} \\
+B(\mathrm{tg}) \quad 0.5-1.0 \mathrm{~m}\end{array}$ & $\begin{array}{r}\text { IX } \\
\text { VIII,X, } \\
\text { XI }\end{array}$ \\
\hline 37 & $\overline{-}$ & $\overline{-}$ & $\overline{-}$ & $\begin{array}{l}S(m r) \quad 20-60 \mathrm{~cm} \\
S(m r) 20-60 \mathrm{~cm} \\
+B(t g) \quad 0.5-1.0 \mathrm{~m}\end{array}$ & $\begin{array}{r}I X \\
\text { VIII,X, } \\
X I\end{array}$ \\
\hline $\begin{array}{l}38 \\
\text { See } \\
\text { note } \\
\text { XIII }\end{array}$ & $\bar{z}$ & $\overline{-}$ & $\begin{array}{l}\geq 10 \mathrm{~m} \\
\geq 10 \mathrm{~m}\end{array}$ & $\begin{array}{l}C C A(s r) 100-300 \mathrm{~cm} \\
C C A(s r) 100-300 \mathrm{~cm} \\
+B(t g) 1 \mathrm{~m} \\
S(m r) 70-200 \mathrm{~cm} \\
S(m r) 70-200 \mathrm{~cm} \\
+B(t g) 1 \mathrm{~m}\end{array}$ & $\begin{array}{l}I X \\
V I I I, X, \\
\quad I I, X I \\
I X \\
\text { VIII,X, } \\
\quad I I I, X I\end{array}$ \\
\hline
\end{tabular}

*Authors' estimates of support. Insufficlent case records available for confident prediction of support requirements. 
Supplementary Notes for Support Tables (from Barton et al. 1974)

I. For cases of heavy rock bursting or "popping", tensioned bolts with enlarged bearing plates often used, with spacing of about $1 \mathrm{~m}$ (occasionally down to $0.8 \mathrm{~m}$ ). Final support when "popping" activity ceases. (Selmer-Olsen, 1970)

II. Several bolt lengths often used in same excavation, i.e. 3,5 and $7 \mathrm{~m}$. 。

III. Several bolt lengths often used in same excavation, i.e. 2,3 and $4 \mathrm{~m}$.

IV. Tensioned cable anchors often used to supplement bolt support pressures. Typical spacing 2-4 m.

V. Several bolt lengths often used in same excavations, i.e. 6,8 and $10 \mathrm{~m}$.

VI. Tensioned cable anchors often used to supplement bolt support pressures. Typical spacing 4-6 m.

VII. Several of the older generation power stations in this category employ systematic or spot bolting with areas of chain link mesh, and a free span concrete arch roof $(25-40 \mathrm{~cm})$ as permanent support.

VIII. Cases involving swelling, for instance montmorillonite clay (with access of water). Room for expansion behind the support is used in cases of heavy swelling. See Selmer-Olsen (1970). Drainage measures are used where possible.

IX. Cases not involving swelling clay or squeezing rock.

$\mathrm{X}$. Cases involving squeezing rock. Heavy rigid support is generally used as permanent support.

XI. According to the authors' experience, in cases of swelling or squeezing, the temporary support required before concrete (or shotcrete) arches are formed may consist of bolting (tensioned shell-expansion type) if the value of $\mathrm{RQD} / \mathrm{J}_{\mathrm{n}}$ is sufficiently high (i.e. $<1.5$ ), possibly combined with shotcrete. If the crushed rock mass is very heavily jointed or crushed (i.e. $\mathrm{RQD} / \mathrm{J}_{\mathrm{n}}<1.5$, for example a "sugar cube" shear zone in quartzite), then the temporary support may consist of up to several applications of shotcrete. Systematic bolting (tensioned) may by added after casting the concrete, but it may not be effective when $\mathrm{RQD} / \mathrm{J}_{\mathrm{n}}<1.5$, or when a lot of clay is present, unless the bolts are grouted before tensioning. A sufficient length of anchored bolt might also be obtained using quick setting resin anchors in these extremely poor quality rock-masses. Serious occurrences of swelling and/or squeezing rock may require that the concrete arches are taken right up to the face, possibly using a shield as temporary shuttering. Temporary support of the working face may also be required in these cases. 
XII. For reasons of safety, the multiple drift method will often be needed during excavation and supporting of roof arch. Categories 16, 20, 24, 28, 32, 35 (SPAN/ESR < 15 m only).

XIII. Multiple drift method usually needed during excavation and support of arch, walls and floor in cases of heavy squeezing. Category 38 (SPAN/ESR $<10 \mathrm{~m}$ only). 
Rev 1

\section{Appendix G \\ North Ramp Starter Tunnel \\ Fibercrete Crack Mapping}




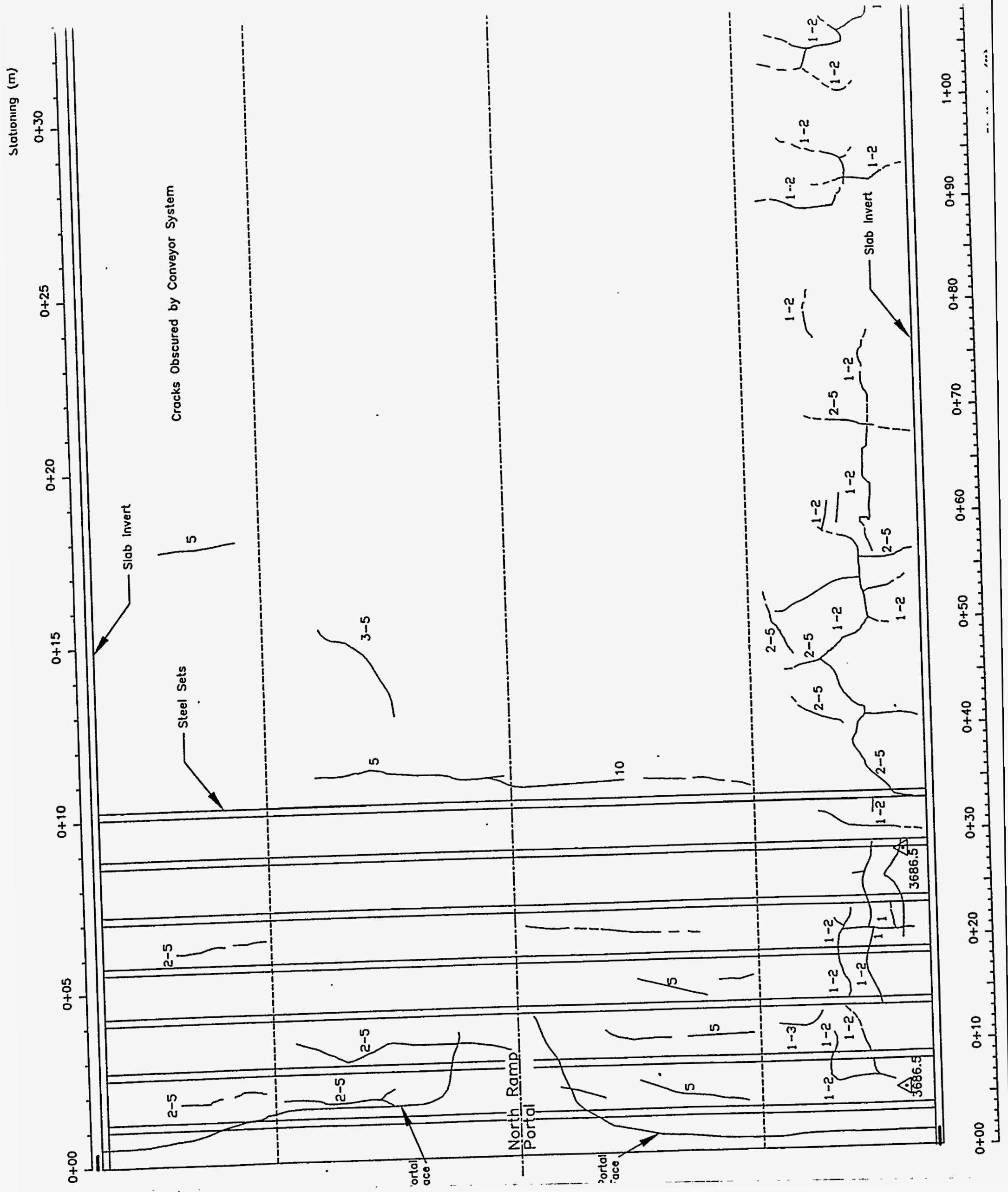




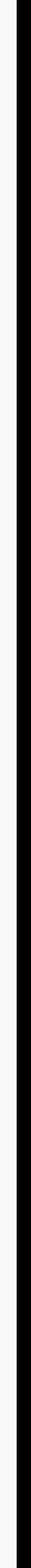




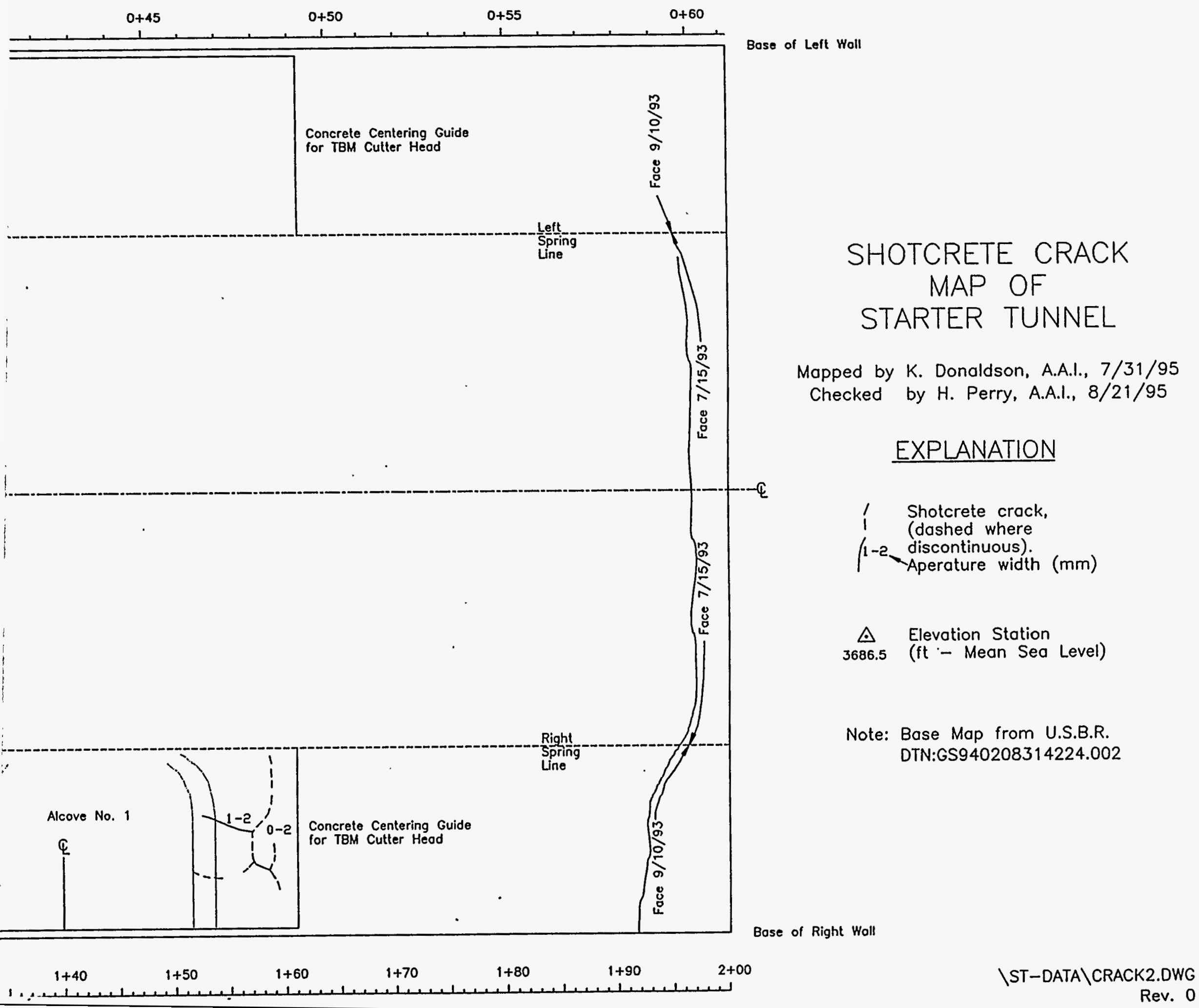





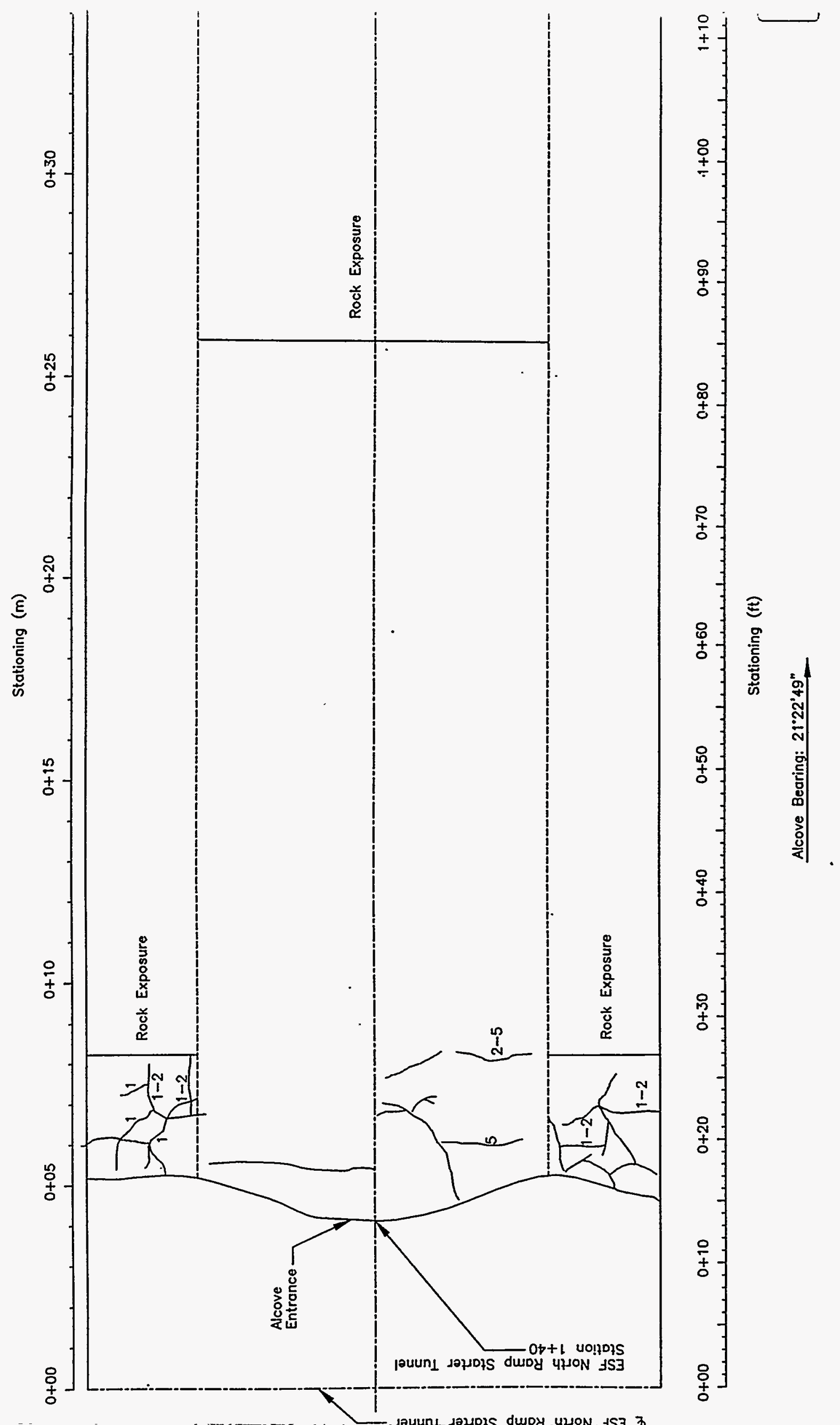




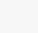


tationing (m)

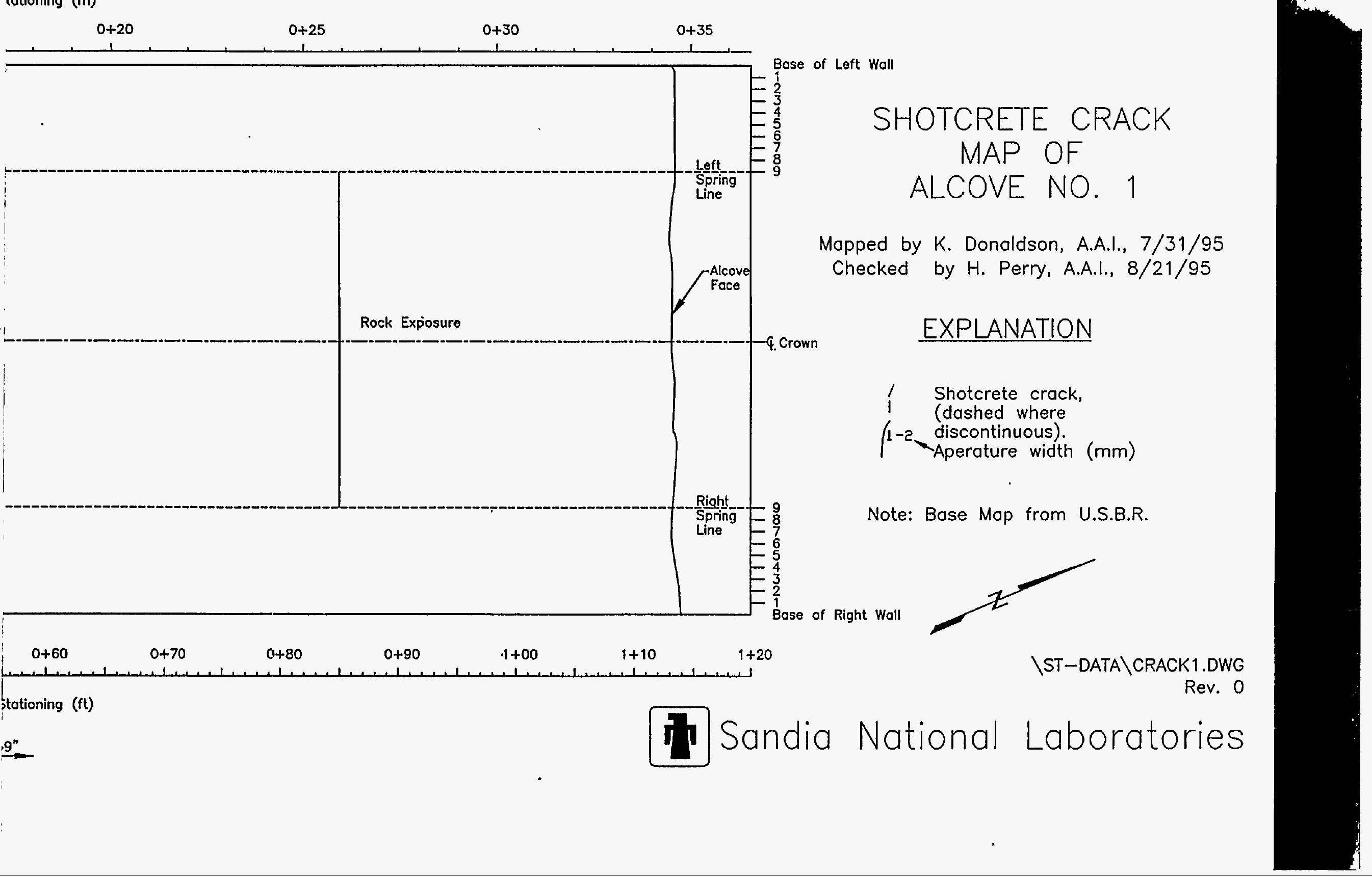





\section{YUCCA MOUNTAIN SITE CHARACTERIZATION PROJECT}

\section{UC814 - DISTRIBUTION LIST}

1

D. A. Dreyfus (RW-1)

Director

OCRWM

US Department of Energy

1000 Independence Avenue SW

Washington, DC 20585

1 L. H. Barrett (RW-2)

Acting Deputy Director

OCRWM

US Department of Energy

1000 Independence Avenue SW

Washington, DC 20585

1 S. Rousso (RW-40)

Office of Storage and Transportation OCRWM

US Department of Energy

1000 Independence Avenue SW

Washington, DC 20585

1 R. A. Milner (RW-30)

Office of Program Management

and Integration

OCRWM

US Department of Energy

1000 Independence Avenue SW

Washington, DC 20585

1 D. R. Elle, Director

Environmental Protection Division

DOE Nevada Field Office

US Department of Energy

P.O. Box 98518

Las Vegas, NV 89193-8518

1 T. Wood (RW-14)

Contract Management Division

OCRWM

US Department of Energy

1000 Independence Avenue SW

Washington, DC 20585

4 Victoria F. Reich, Librarian

Nuclear Waste Technical Review Board

1100 Wilson Blvd., Suite 910

Arlington, VA 22209

5 Wesley Barnes, Project Manager

Yucca Mountain Site Characterization

Office

US Department of Energy

P.O. Box 98608-MS 523

Las Vegas, NV 89193-8608
1 Director

Office of Public Affairs

DOE Nevada Operations Office

US Department of Energy

P.O. Box 98518

Las Vegas, NV 89193-8518

8 Technical Information Officer

DOE Nevada Operations Office

US Department of Energy

P.O. Box 98518

Las Vegas, NV 89193-8518

1 P. K. Fitzsimmons, Technical Advisor

Office of Assistant Manager for

Environmental Safety and Health

DOE Nevada Operations Office

US Department of Energy

P.O. Box 98518

Las Vegas, NV 89193-8518

1 J. A. Blink

Deputy Project Leader

Lawrence Livermore National Laboratory

101 Convention Center Drive

Suite 820, MS 527

Las Vegas, NV 89109

2 J. A. Canepa

Technical Project Officer - YMP

N-5, Mail Stop J521

Los Alamos National Laboratory

P.O. Box 1663

Los Alamos, NM 87545

1 Repository Licensing \& Quality

Assurance

Project Directorate

Division of Waste Management

US NRC

Washington, DC 20555

1

Senior Project Manager for Yucca

Mountain

Repository Project Branch

Division of Waste Management

US NRC

Washington, DC 20555

$1 \quad$ NRC Document Control Desk

Division of Waste Management

US NRC

Washington, DC 20555 
NRC Site Representative

301 E Stewart Avenue, Room 203

Las Vegas, NV 89101

1 E. P. Binnall

Field Systems Group Leader

Building 50B/4235

Lawrence Berkeley Laboratory

Berkeley, CA 94720

$1 \quad$ Center for Nuclear Waste

Regulatory Analyses

6220 Culebra Road

Drawer 28510

San Antonio, TX 78284

2

W. L. Clarke

Technical Project Officer - YMP

Attn: YMP/LRC

Lawrence Livermore National Laboratory

P.O. Box 5514

Livermore, CA 94551

1 V. R. Schneider

Asst. Chief Hydrologist - MS 414

Office of Program Coordination

and Technical Support

US Geological Survey

12201 Sunrise Valley Drive

Reston, VA 22092

1 J. S. Stuckless, Chief

Geologic Studies Program 。

MS 425

Yucca Mountain Project Branch

US Geological Survey

P.O. Box 25046

Denver, CO 80225

$1 \quad$ N. Z. Elkins

Deputy Technical Project Officer

Los Alamos National Laboratory

Mail Stop 527

101 Convention Center Drive, \#820

Las Vegas, NV 89109

2 Michaele C. Brady

Technical Project Officer - YMP

Sandia National Laboratories

Organization 6302, MS 1399

101 Convention Center Drive, Suite 880

Las Vegas, NV 89109

1 Ray Wallace

US Geological Survey

106 National Center

12201 Sunrise Valley Drive

Reston, VA 22092

\section{R. Hayes}

Technical Project Officer

Yucca Mountain Project Branch

MS 425

US Geological Survey

P.O. Box 25046

Denver, CO 80225

1

A. L. Flint

US Geological Survey

MS 721

P.O. Box 327

Mercury, NV 89023

$1 \quad$ R. E. Lewis

Yucca Mountain Project Branch

MS 425

US Geological Survey

P.O. Box 25046

Denver, CO 80225

1 D. Zesiger

US Geological Survey

101 Convention Center Drive

Suite 860, MS 509

Las Vegas, NV 89109

2 L. D. Foust

Nevada Site Manager

TRW Environmental Safety Systems

101 Convention Center Drive

Suite P-110, MS 423

Las Vegas, NV 89109

1

C. E. Ezra

YMP Support Office Manager

EG\&G Energy Measurements Inc.

MS V-02

P.O. Box 1912

Las Vegas, NV 89125

1 E. L. Snow, Program Manager

Roy F. Weston, Inc.

955 L'Enfant Plaza SW

Washington, DC 20024

1 Technical Information Center

Roy F. Weston, Inc.

955 L'Enfant Plaza SW

Washington, DC 20024

1 Technical Project Officer - YMP

US Bureau of Reclamation

Code D-3790

P.O. Box 25007

Denver, CO 80225 
Records Specialist

US Geological Survey

MS 421

P.O. Box 25046

Denver, CO 80225

$1 \quad$ M. D. Voegele

Technical Project Officer - YMP

M\&O/SAIC

101 Convention Center Drive

Suite 407

Las Vegas, NV 89109

1 Paul Eslinger, Manager

PASS Program

Pacific Northwest Laboratories

P.O. Box 999

Richland, WA 99352

1 A. T. Tamura

Science and Technology Division

OSTI

US Department of Energy

P.O. Box 62

Oak Ridge, TN 37831

1 P. J. Weeden, Acting Director

Nuclear Radiation Assessment Div.

\section{US EPA}

Environmental Monitoring Sys. Lab

P.O. Box 93478

Las Vegas, NV 89193-3478

1 ONWI Library

Battelle Columbus Laboratory

Office of Nuclear Waste Isolation

505 King Avenue

Columbus, OH 43201

1 C. H. Johnson

Technical Program Manager

Agency for Nuclear Projects

State of Nevada

Evergreen Center, Suite 252

1802 N. Carson Street

Carson City, NV 89710

1 John Fordham, Deputy Director

Water Resources Center

Desert Research Institute

P.O. Box 60220

Reno, NV 89506

1 The Honorable Cyril Schank

Chairman

Churchill County Board of

Commissioners

190 W. First Street

Fallon, NV 89406
T. Hay, Executive Assistant

Office of the Governor

State of Nevada

Capitol Complex

Carson City, NV 89710

3 R. R. Loux

Executive Director

Agency for Nuclear Projects

State of Nevada

Evergreen Center, Suite 252

1802 N. Carson Street

Carson City, NV 89710

1 Brad R. Mettam

Inyo County Yucca Mountain

Repository Assessment Office

- P. O. Drawer L

Independence, CA 93526

1 Lander County Board of Commissioners

315 South Humbolt Street

Battle Mountain, NV 89820

1 Vernon E. Poe

Office of Nuclear Projects

Mineral County

P.O. Box 1600

Hawthorne, NV 89415

1 Les W. Bradshaw

Program Manager

Nye County Nuclear Waste Repository

Project Office

P.O. Box 1767

Tonopah, NV 89049

1 Florindo Mariani

White Pine County Coordinator

P. O. Box 135

Ely, NV 89301

1 Judy Foremaster

City of Caliente Nuclear Waste

Project Office

P.O. Box 158

Caliente, NV 89008

1 Philip A. Niedzielski-Eichner

Nye County Nuclear Waste

Repository Project Office

P.O. Box 221274

Chantilly, VA 22022-1274 
1 Dennis Bechtel, Coordinator

Nuclear Waste Division

Clark County Department of

Comprehensive Planning

301 E. Clark Avenue, Suite 570

Las Vegas, NV 89101

1 Juanita D. Hoffman

Nuclear Waste Repository

Oversight Program

Esmeralda County

P.O. Box 490

Goldfield, NV 89013

1 Eureka County Board of Commissioners

Yucca Mountain Information Office

P.O. Box 714

Eureka, NV 89316

2

1 Economic Development Dept.

City of Las Vegas

$400 \mathrm{E}$. Stewart Avenue

Las Vegas, NV 89101

1 Community Planning \& Development

City of North Las Vegas

P.O. Box 4086

North Las Vegas, NV 89030

1 Community Development \& Planning

City of Boulder City

P.O. Box 61350

Boulder City, NV 89006

1 Commission of European Communities

200 Rue de la Loi

B-1049 Brussels

BELGIUM

$2 \quad$ Librarian

YMP Research \& Study Center

MS 407

P.O. Box 98521

Las Vegas, NV 89193-8521

1 Amy Anderson

Argonne National Laboratory

Building 362

9700 S. Cass Avenue

Argonne, II 60439

$1 \quad$ Glenn Van Roekel

Director of Community Development

City of Caliente

P.O. Box 158

Caliente, NV 89008
G. S. Bodvarsson

Head, Nuclear Waste Department

Lawrence Berkeley Laboratory

1 Cyclotron Road, MS 50E

Berkeley, CA 94720

1

Michael L. Baughman

Intertech Services Corp.

P.O. Box 93537

Las Vegas, NV 89193

3 Agapito Associates

Attention: Carl Brechtel

3841 W. Charleston, Suite 203

Las Vegas, Nevada 89102

1

University of Nevada, Reno

Attention: J. J. K. Daemen

Mackay School of Mines

Dept. of Mining Engineering

Mail Stop 173

Reno, Nevada 89557-0139

2 MS-1330

C. B. Michaels, 6752

100/WBS 1.2.4.2.1.4, 1.2.3.2.7.3.1, 1.2.3.2.7.3.4

SAND95-1675/QA

20 MS-1330

WMT Library, 6752

MS 1325 R.E. Finley, 6313

MS 1325 L. Costin, 6302

MS 1325 J. Pott, 6313

MS 1325 J.T. George, 6313

MS 1325 E.E. Ryder, 6313

MS 1325 S.R. Sobolik, 6313

MS 1325 R.H. Price, 6313

MS 1325 N.S. Brodsky, 6313

MS 1399

MS 1399

MS 1399

MS 1399

MS 1399

MS 1399

M.C. Brady, 6314

D.S. Kessel, 6314

M. Riggins, 6314

J.E. Grant, 6314

M. Lee, 6314

R.S. Taylor, 6314

MS-9018

MS-0899

MS-0619

Central Technical Files, 8523-2

Technical Library, 4414

Print Media, 12615

MS-0100
Document Processing, 7613-2 for DOE/OSTI 